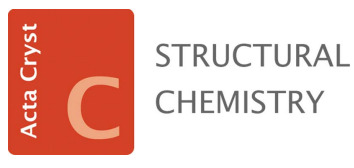

ISSN 2053-2296
Received 5 June 2019

Accepted 19 November 2019

Edited by F. A. Almeida Paz, University of Aveiro, Portugal

Keywords: antiproliferative activity; Schiff base; benzil; indole; reverse docking; crystal structure; quantum chemistry.

CCDC references: $1966764 ; 1966763$. $1966762 ; 1966761 ; 1966760 ; 1966759$; $1966758 ; 1018144$

Supporting information: this article has supporting information at journals.iucr.org/C

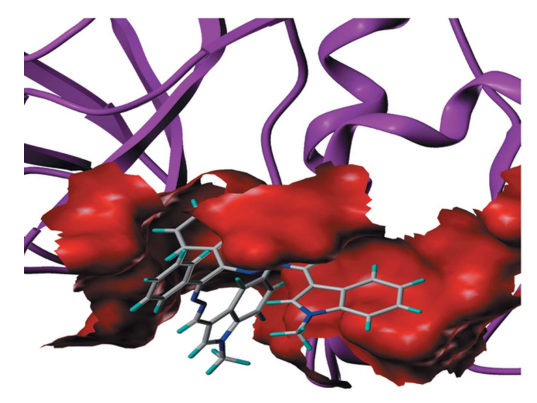

C 2020 International Union of Crystallography

\section{Synthesis, crystal structures, antiproliferative activities and reverse docking studies of eight novel Schiff bases derived from benzil}

\author{
Xue-Jie Tan, ${ }^{\mathrm{a}, \mathrm{b} *}$ Di Wang, ${ }^{\mathrm{a}}$ Xiao-Ming Hei, ${ }^{\mathrm{a}, \mathrm{b}}$ Feng-Cun Yang, ${ }^{\mathrm{a}}$ Ya-Ling Zhu, ${ }^{\mathrm{a}}$ \\ Dian-Xiang Xing ${ }^{\mathrm{a}, \mathrm{b}}$ and Jian-Ping $\mathrm{Ma}^{\mathrm{c}}$
}

\begin{abstract}
aSchool of Chemistry and Pharmaceutical Engineering, Qilu University of Technology (Shandong Academy of Sciences), Jinan, Shandong Province 250353, People's Republic of China, ${ }^{\mathbf{b}}$ Key Laboratory of Pulp and Paper Science \& Technology of Ministry of Education/Shandong Province, Qilu University of Technology (Shandong Academy of Sciences), Jinan, Shandong Province 250353, People's Republic of China, and ${ }^{\mathbf{c} C o l l e g e ~ o f ~ C h e m i s t r y, ~ C h e m i c a l ~ E n g i n e e r i n g ~ a n d ~ M a t e r i a l s ~}$ Science, Collaborative Innovation Centre of Functionalized Probes for Chemical Imaging, Key Laboratory of Molecular and Nano Probes, Ministry of Education, Shandong Normal University, Jinan 250014, People's Republic of China.

*Correspondence e-mail: tanxuejie@163.com
\end{abstract}

Eight novel Schiff bases derived from benzil dihydrazone (BDH) or benzil monohydrazone (BMH) and four fused-ring carbonyl compounds (3-formylindole, FI; 3-acetylindole, AI; 3-formyl-1-methylindole, MFI; 1-formylnaphthalene, FN) were synthesized and characterized by elemental analysis, ESIQTOF-MS, ${ }^{1} \mathrm{H}$ and ${ }^{13} \mathrm{C}$ NMR spectroscopy, as well as single-crystal X-ray diffraction. They are $(1 Z, 2 Z)-1,2$-bis $\{(E)$-[(1H-indol-3-yl)methylidene $]$ hydrazinylidene\}-1,2-diphenylethane (BDHFI), $\mathrm{C}_{32} \mathrm{H}_{24} \mathrm{~N}_{6},(1 Z, 2 Z)$-1,2-bis $\{(E)$-[1(1H-indol-3-yl)ethylidene]hydrazinylidene\}-1,2-diphenylethane (BDHAI), $\mathrm{C}_{34} \mathrm{H}_{28} \mathrm{~N}_{6}, \quad(1 Z, 2 Z)$-1,2-bis $\{(E)$-[(1-methyl-1H-indol-3-yl)methylidene $]$ hydrazinylidene)-1,2-diphenylethane (BMHMFI) acetonitrile hemisolvate, $\mathrm{C}_{34} \mathrm{H}_{28} \mathrm{~N}_{6}$ $0.5 \mathrm{CH}_{3} \mathrm{CN},(1 Z, 2 Z)-1,2-\operatorname{bis}\{(E)$-[(naphthalen-1-yl)methylidene]hydrazinylidene $\}$ 1,2-diphenylethane (BDHFN), $\mathrm{C}_{36} \mathrm{H}_{26} \mathrm{~N}_{4},(Z)-2-\{(E)-[(1 H$-indol-3-yl)methylidene]hydrazinylidene\}-1,2-diphenylethanone (BMHFI), $\mathrm{C}_{23} \mathrm{H}_{17} \mathrm{~N}_{3} \mathrm{O},(Z)-2-\{(E)$ [1-(1H-indol-3-yl)ethylidene]hydrazinylidene)-1,2-diphenylethanone (BMHAI), $\mathrm{C}_{24} \mathrm{H}_{19} \mathrm{~N}_{3} \mathrm{O},(Z)-2-\{(E)$-[(1-methyl- $1 H$-indol-3-yl)methylidene $]$ hydrazinylidene $\}$ 1,2-diphenylethanone (BMHMFI), $\mathrm{C}_{24} \mathrm{H}_{19} \mathrm{~N}_{3} \mathrm{O}$, and $(Z)-2-\{(E)-[($ naphthalen-1yl)methylidene]hydrazinylidene\}-1,2-diphenylethanone (BMHFN) $\mathrm{C}_{25} \mathrm{H}_{18} \mathrm{~N}_{2} \mathrm{O}$. Moreover, the in vitro cytotoxicity of the eight title compounds was evaluated against two tumour cell lines (A549 human lung cancer and 4T $\mathrm{T}_{1}$ mouse breast cancer) and two normal cell lines (MRC-5 normal lung cells and NIH 3T3 fibroblasts) by MTT assay. The results indicate that four (BDHMFI, BDHFN, BMHMFI and BMHFN) are inactive and the other four (BDHFI, BDHAI, BMHFI and BMHAI) show severe toxicities against human A549 and mouse $4 \mathrm{~T}_{1}$ cells, similar to the standard cisplatin. All the compounds exhibited weaker cytotoxicity against normal cells than cancer cells. The Swiss Target Prediction web server was applied for the prediction of protein targets. After analyzing the differences in frequency hits between these active and inactive Schiff bases, 18 probable targets were selected for reverse docking with the Surflex-dock function in $S Y B Y L-X 2.0$ software. Three target proteins, i.e. human ether-á-gogo-related (hERG) potassium channel, the inhibitor of apoptosis protein 3 and serine/threonine-protein kinase PIM1, were chosen as the targets. Finally, the ligand-based structure-activity relationships were analyzed based on the putative protein target (hERG) docking results, which will be used to design and synthesize novel hERG ion channel inhibitors.

\section{Introduction}

Schiff bases are important compounds in chemistry and biochemistry due to their flexibility (Mayans et al., 2018; Pramanik et al., 2018), easy preparation (Erxleben, 2018; 
Ganguly et al., 2014), exceptional chelating ability (Malik et al., 2018; Vardhan et al., 2015) and to their broad spectrum of biological and pharmaceutical activities, such as antimicrobial (Anush et al., 2018; Unver \& Bektas, 2018; Bharathi et al., 2018; Carreño et al., 2018), anti-inflammatory (Venkatesan et al., 2018; Farag et al., 2017; Bano et al., 2017; Khayyat et al., 2015) and anticancer properties (Unver \& Bektas, 2018; Santhosh Kumar et al., 2018; Kalaiarasi et al., 2018; Ariyaeifar et al., 2018). Thus, the chemistry of Schiff bases has always been a promising field of research.

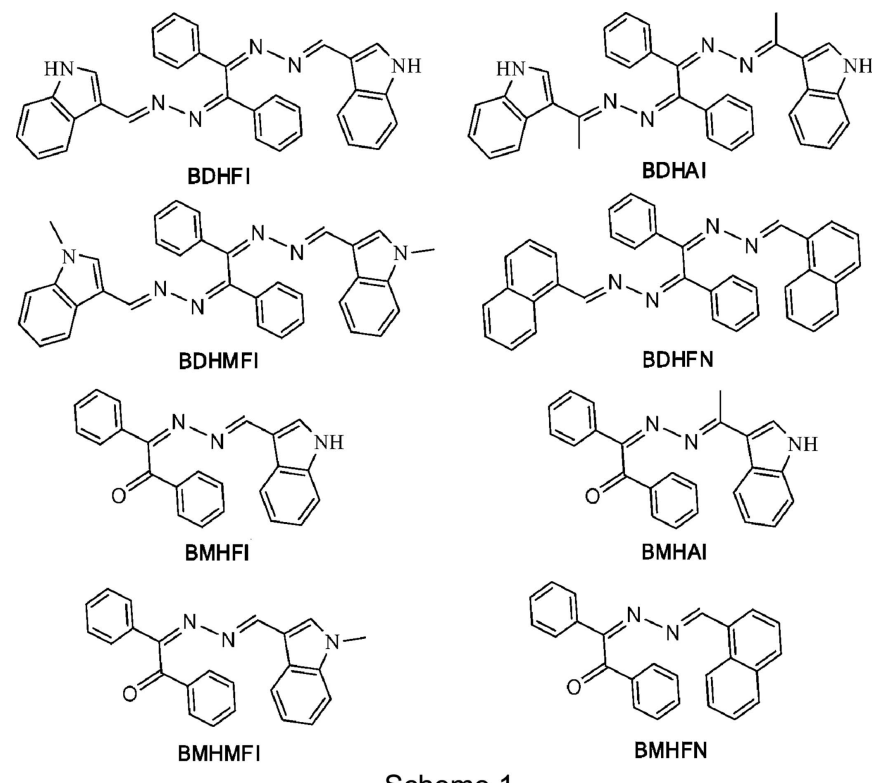

Scheme 1

As an organic helical molecule with a long history (De et al., 2006; Fisher \& Stoufer, 1966), benzil dihydrazone (BDH) is often used to construct polydentate diazine Schiff bases (Tan et al., 2015), helical coordination complexes (Bai et al., 2012; Drew et al., 2007; Mukherjee et al., 2013) and, more importantly, a leading scaffold for the further design and synthesis of potential anticancer agents (Ke et al., 2013). Here we aimed to use the BDH scaffold to construct some novel Schiff bases, especially those containing indole rings. Another set of novel Schiff bases based on benzil monohydrazone (BMH) were also constructed for comparison.

As a privileged structure scaffold (de Sá Alves et al., 2009; Evans et al., 1988), indole derivatives play an important role in medicinal chemistry since they frequently exhibit broad and remarkable biological activities. Substituted indole rings have revealed antibacterial (El-Sawy et al., 2010; George et al., 2008), antitumour (Pedada et al., 2016; Fortes et al., 2016; ElSawy et al., 2012, 2013; Wu et al., 2009; Pojarová et al., 2007; Kamath et al., 2016), antifungal (Bai et al., 2018; Wang et al., 2018; Mishra et al., 2018; Yu et al., 2018), antiviral (CihanÜstündağ et al., 2016; Brigg et al., 2016; Zhao et al., 2006; Sellitto et al., 2010; Pu et al., 2017; Atienza et al., 2018), antiinflammatory (Mandour et al., 2010; Lamie et al., 2016), antioxidant (Estevão et al., 2010; Suzen \& Buyukbingol, 2000; Mor et al., 2004), antituberculosis (Naidu et al., 2016; Zhao, 2018; Hong et al., 2017; Akula et al., 2016), analgesic (Fantinati et al., 2017; Bertamino et al., 2018; Ali Khan et al., 2018), anti- convulsant (Saini et al., 2016; Ndagijimana et al., 2013; Ma et al., 2016; Ensch et al., 2018) and many other therapeutic and pharmacological properties. Numerous pharmaceutical molecules with the indole group have been marketed. These include indomethacin, zafirlukast, sumatriptan, indole-3-acetic acid (IAA), serotonin, delavirdine, atevirdine etc. There are also large numbers of indole-containing drugs currently going through different clinical phases (Naim et al., 2016). Moreover, the indole nucleus is commonly found in several natural products and displays an indispensable role in therapeutic chemistry (Tzvetkov et al., 2014; Gurer-Orhan et al., 2016; Kumar et al., 2016; Johansson et al., 2013; Blunt et al., 2011; Gul \& Hamann, 2005; Sugiyama et al., 2009; Bao et al., 2007; Shaaban et al., 2002; Shaaban \& Abdel-Aziz, 2007; Ali Khan et al., 2018; Ndagijimana et al., 2013). Although indole derivatives have been the target of synthetic exploration for many years, more anticancer compounds incorporating the indole scaffold with improved anticancer properties are desired for the systematic study of structure-activity relationships (Hassam et al., 2012; Dai et al., 2016; Singh et al., 2018).

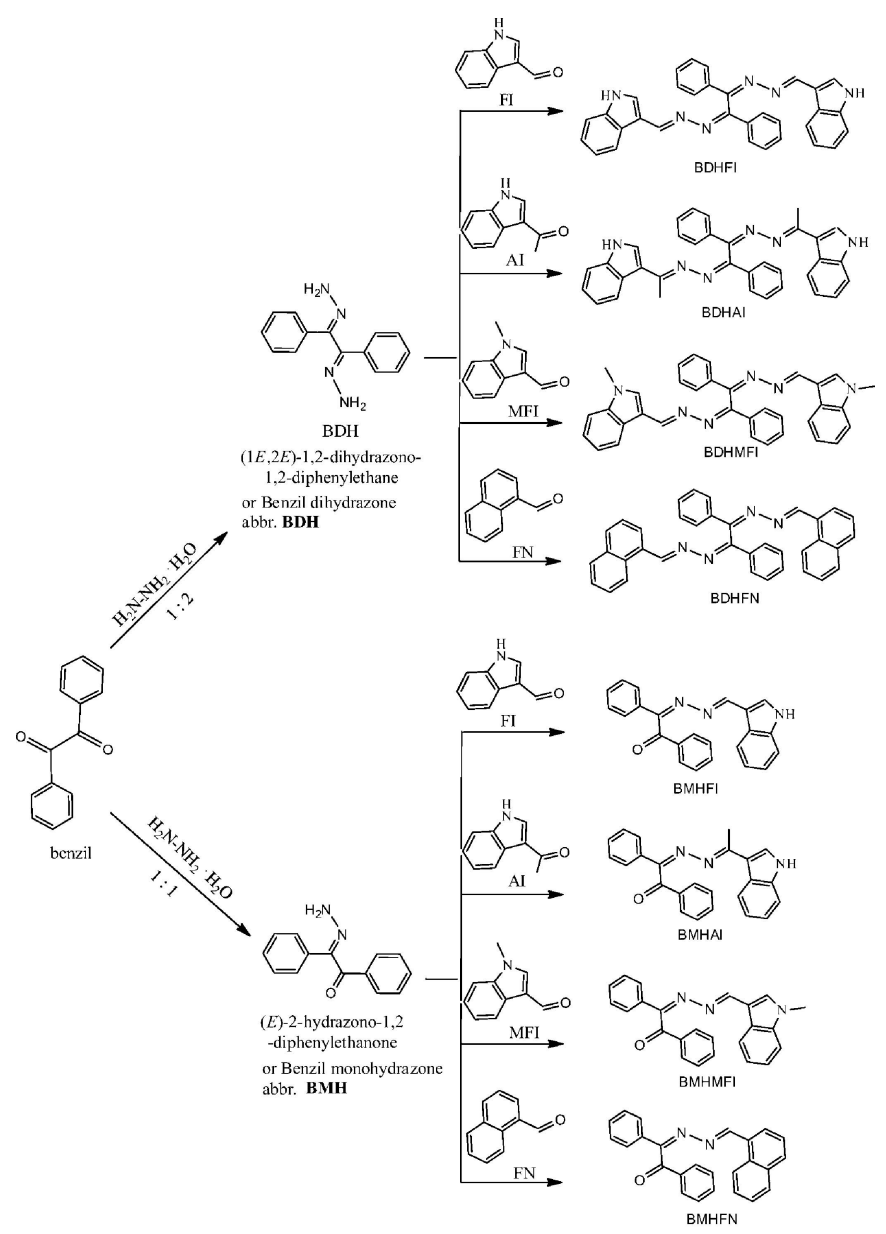

Scheme 2

In order to gain a deeper insight into the antitumour activity of various functionalized indoles, we have been conducting a systematic study on indole derivatives with different scaffolds, for example, novel Schiff bases derived from indole and biphenyl show lung A549 and breast $4 \mathrm{~T}_{1}$ cancer cell inhibitory activities $\left(\mathrm{IC}_{50}=20.5\right.$ and $18.5 \mu M$, respectively) (Bu et al., 
2017; Tan et al., 2019). We report here the synthesis, crystal structure and antiproliferative activities of six Schiff bases derived from indole and BDH/BMH, as well as two comparative compounds derived from naphthalene and BDH/ BMH (see Scheme 1).

\section{Experimental}

\subsection{Materials and measurements}

The starting material benzil and related chemicals were purchased from Aladdin Reagent Chemicals and were used without further purification. Elemental $(\mathrm{C}, \mathrm{H}$ and $\mathrm{N})$ analyses were carried out with a PerkinElmer 2400 microanalyzer. Accurate mass measurements were acquired on an Agilent6520 quadrupole time-of-flight tandem mass spectrometer. Melting points were determined on a WRS-2A electrothermal digital melting point apparatus (Shanghai Precision \& Scientific Instrument Co. Ltd, China). ${ }^{1} \mathrm{H}$ and ${ }^{13} \mathrm{C}$ NMR spectra were recorded on a Bruker Avance $400 \mathrm{MHz}$ instrument. The chemical shifts are reported in parts per million (ppm) relative to tetramethylsilane $\left(\mathrm{SiMe}_{4}, \delta=0 \mathrm{ppm}\right)$, referenced to the chemical shifts of the residual solvent peak [deuterated dimethyl sulfoxide (DMSO- $d_{6}$ )].

\subsection{Synthesis and crystallization}

As indicated in Scheme 2, a two-step process was used to synthesize all eight title compounds. In the first step, a mixture of benzil $(0.42 \mathrm{~g}$ or $2 \mathrm{mmol})$ and hydrazine hydrate $(80 \%$, $0.20 \mathrm{ml}$ or $4 \mathrm{mmol})$ was added to dry ethanol $(20 \mathrm{ml})$ and the resulting solution refluxed for $3 \mathrm{~h}$. Most of the ethanol was removed by distillation and the resulting solution was cooled to room temperature. Crude benzil dihydrazone (abbreviated as BDH) was filtered off, recrystallized from ethanol and dried in a vacuum. Pure BDH was obtained as colourless needleshaped crystals \{yield $85 \%, 0.41 \mathrm{~g}$; m.p. $151.4-152.0^{\circ} \mathrm{C}$ [literature m.p. 151-152 (Bach et al., 1982), 150-151.5 (Kim \& Yoon, 2004), 149 (Salavati-Niasari \& Hassani-Kabutarkhani, 2005), 152 (Chandra et al., 2007), 172 (Singh et al., 2008) and $172{ }^{\circ} \mathrm{C}$ (Chauhan et al., 2008)]\}. Elemental analysis found (calculated) for $\mathrm{C}_{14} \mathrm{H}_{14} \mathrm{~N}_{4}$ (\%): C 70.64 (70.57), H 5.97 (5.92), $\mathrm{N} 23.63$ (23.51). On the other hand, if the molar ratio of benzil and hydrazine hydrate was set at 1:1, benzil monohydrazone (BMH) will be obtained in a similar yield. Pure BMH was obtained as a colourless crystal (m.p. $138.4-139.2^{\circ} \mathrm{C}$ ).

In the second step, all eight Schiff bases were readily prepared by a similar method (see Scheme 2). BDH/BMH and the required carbonyl compounds (FI, AI, MFI and FN) were stirred under reflux for $5 \mathrm{~h}$ in dry ethanol in a 1:2 (BDH versus carbonyl compounds) or 1:1 (BMH versus carbonyl compounds) molar ratio. After the reaction, the solvent was reduced in volume by slow evaporation and crystalline products were usually obtained. Recrystallization can purify the products. Their physical and spectroscopic properties are listed in the following sections. All NMR spectra are available in Figs. S1-S16 of the supporting information.
2.2.1. BDHFI. M.p. $274.0-275.0^{\circ} \mathrm{C}$. Elemental analysis found (calculated) for $\mathrm{C}_{32} \mathrm{H}_{24} \mathrm{~N}_{6}$ (\%): $\mathrm{C} 78.15$ (78.03), $\mathrm{H} 4.98$ (4.91), N 17.12 (17.06). HRMS (ESI): $\mathrm{m} / \mathrm{z}$ calculated for $\mathrm{C}_{32} \mathrm{H}_{24} \mathrm{~N}_{6}+\mathrm{H}^{+}: 493.2141\left[M+\mathrm{H}^{+}\right]$; found: 493.2142. ${ }^{1} \mathrm{H}$ NMR $\left(\right.$ DMSO- $\left.d_{6}\right): 11.637(s, 2 \mathrm{H},-\mathrm{NH}), 8.757(s, 2 \mathrm{H},-\mathrm{N}=\mathrm{CH})$, $7.878-7.825(m, 6 \mathrm{H}, J=7.2 \mathrm{~Hz}, \mathrm{Ar}-\mathrm{H}), 7.587(d, 2 \mathrm{H}, J=8.0 \mathrm{~Hz}$, Ar-H), $7.450(d, 6 \mathrm{H}, J=8.0 \mathrm{~Hz}, \mathrm{Ar}-\mathrm{H}), 7.330(d, 2 \mathrm{H}, J=8.0 \mathrm{~Hz}$, Ar-H), $7.076(t, 2 \mathrm{H}, J=8.0 \mathrm{~Hz}, \mathrm{Ar}-\mathrm{H}), 6.851(t, 2 \mathrm{H}, J=7.2 \mathrm{~Hz}$, Ar-H). ${ }^{13} \mathrm{C}$ NMR (DMSO- $\left.d_{6}\right): 163.575(\mathrm{CH}=\mathrm{N}), 156.485$ $(\mathrm{CH}=\mathrm{N}), 136.992$ (Ar-C), 135.007 (Ar-C), 132.951 (Ar-C), 130.035 (Ar-C), 128.589 (Ar-C), 126.989 (Ar-C), 124.433 (Ar-C), 122.596 (Ar-C), 122.267 (Ar-C), 120.478 (Ar-C), 112.165 (Ar-C), 111.629 (Ar-C).

2.2.2. BDHAI. M.p. $270.2-271.7^{\circ} \mathrm{C}$. Elemental analysis found (calculated) for $\mathrm{C}_{34} \mathrm{H}_{28} \mathrm{~N}_{6}$ (\%): C 78.49 (78.44), H 5.47 (5.42), N 16.21 (16.14). HRMS (ESI): $\mathrm{m} / \mathrm{z}$ calculated for $\mathrm{C}_{34} \mathrm{H}_{28} \mathrm{~N}_{6}+\mathrm{H}^{+}: 521.2454\left[M+\mathrm{H}^{+}\right]$; found: 521.2456. ${ }^{1} \mathrm{H}$ NMR (DMSO- $\left.d_{6}\right): 11.473(s, 2 \mathrm{H},-\mathrm{NH}), 7.877-7.754(m, 8 \mathrm{H}, J=$ $6.8 \mathrm{~Hz}, \mathrm{Ar}-\mathrm{H}), 7.452-7.271(m, 8 \mathrm{H}, J=6.8 \mathrm{~Hz}, \mathrm{Ar}-\mathrm{H}), 7.020(s$, $2 \mathrm{H}, \mathrm{Ar}-\mathrm{H}), 6.713(s, 2 \mathrm{H}, \mathrm{Ar}-\mathrm{H}), 2.418\left(s, 6 \mathrm{H}-\mathrm{CH}_{3}\right) .{ }^{13} \mathrm{C} \mathrm{NMR}$ $\left(\right.$ DMSO- $\left.d_{6}\right): 161.007(\mathrm{CH}=\mathrm{N}), 136.915(\mathrm{CH}=\mathrm{N}), 135.117$ (Ar-C), 129.884 (Ar-C), 129.587 (Ar-C), 128.598 (Ar-C), 128.292 (Ar-C), 127.405 (Ar-C), 126.942 (Ar-C), 124.815 (Ar-C), 124.730 (Ar-C), 123.487 (Ar-C), 122.003 (Ar-C), 119.916 (Ar-C), 115.206 (Ar-C), 111.184 (Ar-C), 14.792 $\left(-\mathrm{CH}_{3}\right)$.

2.2.3. BDHMFI. M.p. $214.6-215.3^{\circ} \mathrm{C}$. Elemental analysis found (calculated) for $\mathrm{C}_{34} \mathrm{H}_{28} \mathrm{~N}_{6}$ (\%): C 78.51 (78.44), H 5.46 (5.42), N 16.19 (16.14). HRMS (ESI): $\mathrm{m} / \mathrm{z}$ calculated for $\mathrm{C}_{34} \mathrm{H}_{28} \mathrm{~N}_{6}+\mathrm{H}^{+}: 521.2454\left[M+\mathrm{H}^{+}\right]$; found: 521.2454. ${ }^{1} \mathrm{H}$ NMR (DMSO- $\left.d_{6}\right): 8.731(s, 2 \mathrm{H},-\mathrm{N}=\mathrm{CH}), 7.874(d, 4 \mathrm{H}, J=7.2 \mathrm{~Hz}$, Ar-H), $7.789(s, 2 \mathrm{H}, \mathrm{Ar}-\mathrm{H}), 7.602(d, 2 \mathrm{H}, J=7.2 \mathrm{~Hz}, \mathrm{Ar}-\mathrm{H})$, 7.474-7.373 ( $m, 8 \mathrm{H}, \mathrm{Ar}-\mathrm{H}), 7.151(t, 2 \mathrm{H}, J=7.2 \mathrm{~Hz}, \mathrm{Ar}-\mathrm{H})$, $6.908(t, 2 \mathrm{H}, J=7.2 \mathrm{~Hz}, \mathrm{Ar}-\mathrm{H}), 3.733\left(s, 6 \mathrm{H}-\mathrm{N}-\mathrm{CH}_{3}\right) .{ }^{13} \mathrm{C}$ NMR (DMSO- $\left.d_{6}\right): 163.813(\mathrm{CH}=\mathrm{N}), 155.643(\mathrm{CH}=\mathrm{N})$, 137.807 (Ar-C), 137.575 (Ar-C), 136.220 (Ar-C), 136.059 (Ar-C), 129.753 (Ar-C), 128.178 (Ar-C), 127.936 (Ar-C), 127.608 (Ar-C), 124.885 (Ar-C), 122.636 (Ar-C), 122.121 (Ar-C), 120.644 (Ar-C), 111.325 (Ar-C), 110.007 (Ar-C), $32.770\left(-\mathrm{N}-\mathrm{CH}_{3}\right)$.

2.2.4. BDHFN. M.p. $203.0-205.0^{\circ} \mathrm{C}$. Elemental analysis found (calculated) for $\mathrm{C}_{36} \mathrm{H}_{26} \mathrm{~N}_{4}$ (\%): C 84.08 (84.02), H 5.13 (5.09), N 10.94 (10.89). HRMS (ESI): $\mathrm{m} / \mathrm{z}$ calculated for $\mathrm{C}_{36} \mathrm{H}_{26} \mathrm{~N}_{4}+\mathrm{H}^{+}: 515.2236\left[M+\mathrm{H}^{+}\right]$; found: 515.2236. ${ }^{1} \mathrm{H}$ NMR $\left(\right.$ DMSO- $\left.d_{6}\right): 8.770(s, 2 \mathrm{H},-\mathrm{N}=\mathrm{CH}), 8.277(t, 4 \mathrm{H}, J=7.6 \mathrm{~Hz}$, Ar-H), 7.883-7.766 ( $m, 6 \mathrm{H}, \mathrm{Ar}-\mathrm{H}), 7.585(d, 2 \mathrm{H}, J=8.0 \mathrm{~Hz}$, Ar-H), 7.482-7.326 ( $m, 8 \mathrm{H}, \mathrm{Ar}-\mathrm{H}), 7.082(t, 2 \mathrm{H}, J=7.6 \mathrm{~Hz}, \mathrm{Ar}-$ $\mathrm{H}), 6.857(t, 2 \mathrm{H}, J=7.6 \mathrm{~Hz}, \mathrm{Ar}-\mathrm{H}) .{ }^{13} \mathrm{C}$ NMR (DMSO- $\left.d_{6}\right)$ : $163.655(\mathrm{CH}=\mathrm{N}), 156.624(\mathrm{CH}=\mathrm{N}), 139.670(\mathrm{Ar}-\mathrm{C}), 137.877$ (Ar-C), 136.970 (Ar-C), 134.977 (Ar-C), 133.068 (Ar-C), 130.076 (Ar-C), 128.623 (Ar-C), 126.980 (Ar-C), 124.391 (Ar-C), 122.620 (Ar-C), 122.270 (Ar-C), 120.504 (Ar-C), 112.123 (Ar-C), 111.655 (Ar-C).

2.2.5. BMHFI. M.p. $197-197.5^{\circ} \mathrm{C}$. Elemental analysis found (calculated) for $\mathrm{C}_{23} \mathrm{H}_{17} \mathrm{~N}_{3} \mathrm{O}$ (\%): C 77.59 (78.61), H 5.13 (4.88), N 12.22 (11.96). HRMS (ESI): $\mathrm{m} / \mathrm{z}$ calculated for $\mathrm{C}_{23} \mathrm{H}_{17} \mathrm{~N}_{3} \mathrm{O}+\mathrm{H}^{+}: 352.1450\left[M+\mathrm{H}^{+}\right]$; found: $352.1450 .{ }^{1} \mathrm{H}$ 
Table 1

Experimental details.

Experiments were carried out with Mo K $\alpha$ radiation using a Bruker SMART CCD area detector. Absorption was corrected by multi-scan methods (SADABS; Bruker, 2000). Only $\mathrm{H}$ atoms were constrained to ride on their bonding partners, but with freely refined $U_{\text {iso }}$ values.

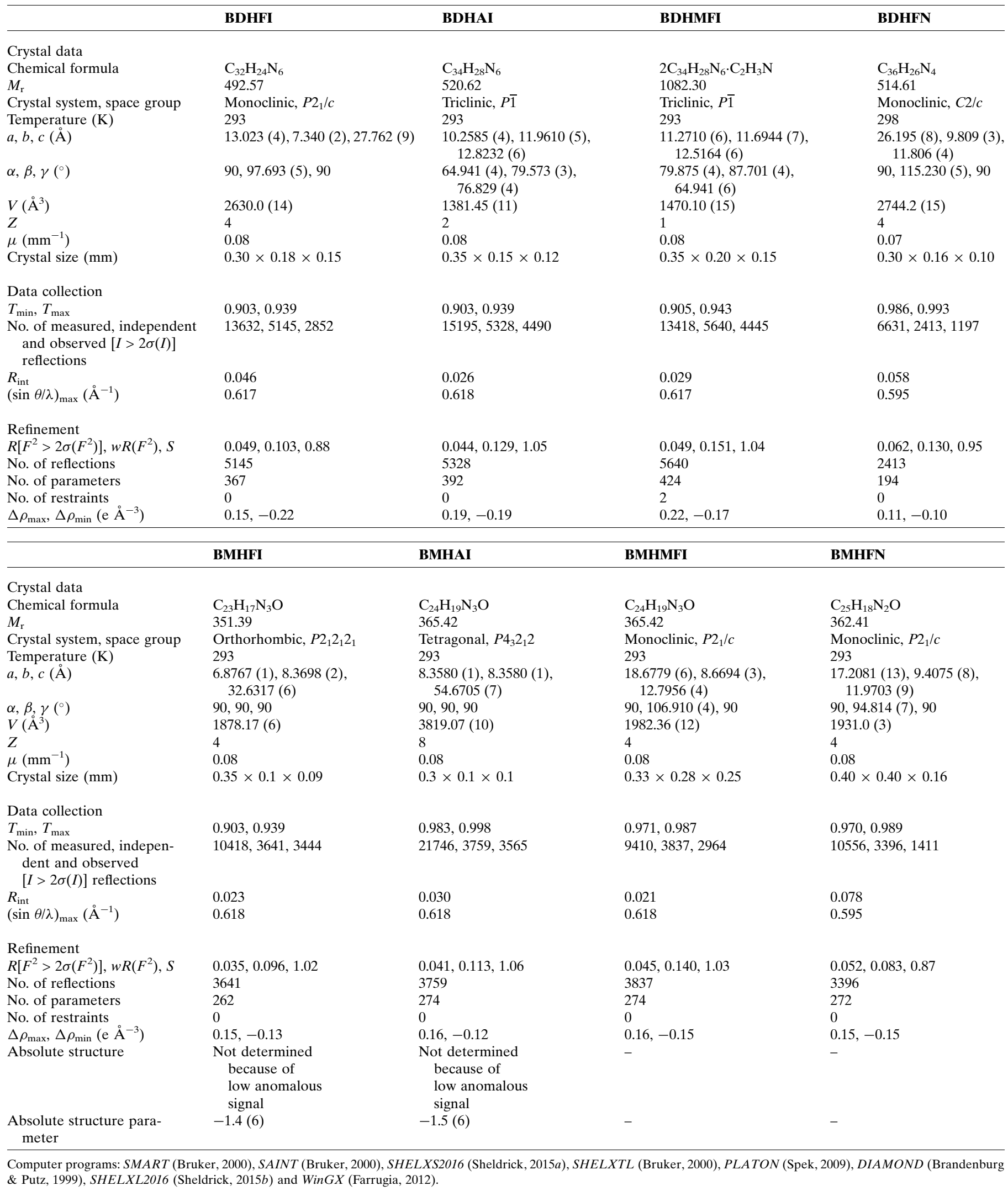


NMR (DMSO- $\left.d_{6}\right): 11.800(s, 1 \mathrm{H},-\mathrm{NH}), 8.800(s, 1 \mathrm{H}$, $-\mathrm{N}=\mathrm{CH}), 7.961-7.928(m, 3 \mathrm{H}, J=7.2 \mathrm{~Hz}$, Ar-H), 7.767-7.218 $(m, 10 \mathrm{H}, \mathrm{Ar}-\mathrm{H}), 7.087(t, 1 \mathrm{H}, J=7.6 \mathrm{~Hz}, \mathrm{Ar}-\mathrm{H}), 6.789(t, 1 \mathrm{H}, J=$ 7.6 Hz, Ar-H) ${ }^{13} \mathrm{C}$ NMR (DMSO- $\left.d_{6}\right): 197.921(\mathrm{C}=\mathrm{O}), 163.669$ $(\mathrm{CH}=\mathrm{N}), 158.076(\mathrm{CH}=\mathrm{N}), 137.065($ Ar-C), $135.223($ Ar-C), 134.228 (Ar-C), 134.056 (Ar-C), 132.698 (Ar-C), 131.033 (Ar-C), 130.507 (Ar-C), 129.266 (Ar-C), 129.180 (Ar-C), 128.936 (Ar-C), 128.554 (Ar-C), 128.369 (Ar-C), 127.445 (Ar-C), 126.900 (Ar-C), 124.230 (Ar-C), 122.793 (Ar-C), 121.724 (Ar-C), 120.659 (Ar-C), 111.860 (Ar-C), 111.605 (Ar-C).

2.2.6. BMHAI. M.p. $223.1-224.4^{\circ} \mathrm{C}$. Elemental analysis found (calculated) for $\mathrm{C}_{24} \mathrm{H}_{19} \mathrm{~N}_{3} \mathrm{O}$ (\%): $\mathrm{C} 79.24$ (78.88), $\mathrm{H} 6.11$ (5.24), N 12.03 (11.50). HRMS (ESI): $\mathrm{m} / \mathrm{z}$ calculated for $\mathrm{C}_{24} \mathrm{H}_{19} \mathrm{~N}_{3} \mathrm{O}+\mathrm{H}^{+}$: $366.1606\left[M+\mathrm{H}^{+}\right]$; found: 366.1606. ${ }^{1} \mathrm{H}$ NMR (DMSO- $\left.d_{6}\right): 11.644(s, 1 \mathrm{H},-\mathrm{NH}), 8.028-7.503(m, 11 \mathrm{H}$, $J=6.8 \mathrm{~Hz}, \mathrm{Ar}-\mathrm{H}), 7.318-7.266(q, 2 \mathrm{H}, J=8.4 \mathrm{~Hz}, \mathrm{Ar}-\mathrm{H}), 7.034-$ $6.998(t, 1 \mathrm{H}, J=7.2 \mathrm{~Hz}, \mathrm{Ar}-\mathrm{H}), 6.649-6.612(t, 1 \mathrm{H}, J=7.2 \mathrm{~Hz}$, Ar-H), $2.584\left(s, 3 \mathrm{H}-\mathrm{CH}_{3}\right) .{ }^{13} \mathrm{C}$ NMR (DMSO- $\left.d_{6}\right): 198.911$ $(\mathrm{C}=\mathrm{O}), 163.948(\mathrm{CH}=\mathrm{N}), 161.192(\mathrm{CH}=\mathrm{N}), 136.957($ Ar-C), 134.953 (Ar-C), 134.166 (Ar-C), 133.209 (Ar-C), 131.003 (Ar-C), 130.813 (Ar-C), 129.467 (Ar-C), 129.226 (Ar-C), 129.056 (Ar-C), 128.868 (Ar-C), 126.831 (Ar-C), 124.468 (Ar-C), 122.699 (Ar-C), 122.632 (Ar-C), 122.147 (Ar-C), 121.559 (Ar-C), 121.275 (Ar-C), 120.132 (Ar-C), 114.671 (Ar-C), 111.414 (Ar-C), $14.688\left(-\mathrm{CH}_{3}\right)$.

2.2.7. BMHMFI. M.p. $220.1-221.3{ }^{\circ} \mathrm{C}$. Elemental analysis found (calculated) for $\mathrm{C}_{24} \mathrm{H}_{19} \mathrm{~N}_{3} \mathrm{O}$ (\%): $\mathrm{C} 79.25$ (78.88), $\mathrm{H} 5.65$ (5.24), N 11.89 (11.50). HRMS (ESI): $\mathrm{m} / \mathrm{z}$ calculated for $\mathrm{C}_{24} \mathrm{H}_{19} \mathrm{~N}_{3} \mathrm{O}+\mathrm{H}^{+}$: $366.1606\left[M+\mathrm{H}^{+}\right]$; found: $366.1606 .{ }^{1} \mathrm{H}$ NMR (DMSO- $\left.d_{6}\right): 8.764(s, 1 \mathrm{H},-\mathrm{N}=\mathrm{CH}), 7.927(d, 3 \mathrm{H}, J=$ $8.4 \mathrm{~Hz}, \mathrm{Ar}-\mathrm{H}), 7.749$ (d, 2H, $J=7.6 \mathrm{~Hz}, \mathrm{Ar}-\mathrm{H}), 7.665-7.421(m$, $8 \mathrm{H}, \mathrm{Ar}-\mathrm{H}), 7.239-7.138(m, 1 \mathrm{H}, \mathrm{Ar}-\mathrm{H}), 6.834(t, 1 \mathrm{H}, J=7.2 \mathrm{~Hz}$, Ar-H), $3.799\left(s, 3 \mathrm{H}-\mathrm{N}-\mathrm{CH}_{3}\right) .{ }^{13} \mathrm{C}$ NMR (DMSO- $\left.d_{6}\right): 197.918$ $(\mathrm{C}=\mathrm{O}), 163.667(\mathrm{CH}=\mathrm{N}), 157.569(\mathrm{CH}=\mathrm{N}), 137.675(\mathrm{Ar}-\mathrm{C})$, 137.549 (Ar-C), 135.209 (Ar-C), 134.066 (Ar-C), 132.680 (Ar-C), 131.044 (Ar-C), 130.126 (Ar-C), 129.975 (Ar-C), 129.298 (Ar-C), 129.261 (Ar-C), 129.179 (Ar-C), 129.055 (Ar-C), 128.564 (Ar-C), 126.840 (Ar-C), 124.658 (Ar-C), 122.873 (Ar-C), 121.838 (Ar-C), 120.960 (Ar-C), 110.576 (Ar-C), 110.261 (Ar-C), $32.950\left(-\mathrm{N}-\mathrm{CH}_{3}\right)$.

2.2.8. BMHFN. M.p. $135.2-136.7^{\circ} \mathrm{C}$. Elemental analysis found (calculated) for $\mathrm{C}_{25} \mathrm{H}_{18} \mathrm{~N}_{2} \mathrm{O}$ (\%): $\mathrm{C} 82.18$ (82.85), $\mathrm{H} 5.11$ (5.01), N 7.84 (7.73). HRMS (ESI): $\mathrm{m} / \mathrm{z}$ calculated for $\mathrm{C}_{25} \mathrm{H}_{18} \mathrm{~N}_{2} \mathrm{O}+\mathrm{H}^{+}$: $363.1497\left[M+\mathrm{H}^{+}\right.$]; found: 363.1497. ${ }^{1} \mathrm{H}$ NMR (DMSO- $\left.d_{6}\right): 8.770(s, 1 \mathrm{H},-\mathrm{N}=\mathrm{CH}), 8.275(t, 1 \mathrm{H}, J=$ $7.6 \mathrm{~Hz}, \mathrm{Ar}-\mathrm{H}), 8.167(t, 3 \mathrm{H}, J=7.6 \mathrm{~Hz}, \mathrm{Ar}-\mathrm{H}), 7.852(q, 4 \mathrm{H}, J=$ $7.6 \mathrm{~Hz}, \mathrm{Ar}-\mathrm{H}), 7.589-7.320(m, 6 \mathrm{H}, \mathrm{Ar}-\mathrm{H}), 7.080(t, 2 \mathrm{H}, J=$ $7.2 \mathrm{~Hz}, \mathrm{Ar}-\mathrm{H}), 6.850(t, 1 \mathrm{H}, J=7.6 \mathrm{~Hz}, \mathrm{Ar}-\mathrm{H}) .{ }^{13} \mathrm{C}$ NMR $\left(\right.$ DMSO- $\left.d_{6}\right): 196.873(\mathrm{C}=\mathrm{O}), 162.531 \quad(\mathrm{CH}=\mathrm{N}), 156.980$ $(\mathrm{CH}=\mathrm{N}), 139.701$ (Ar-C), 137.101 (Ar-C), 136.981 (Ar-C), 135.238 (Ar-C), 134.231 (Ar-C), 134.107 (Ar-C), 132.702 (Ar-C), 131.051 (Ar-C), 130.515 (Ar-C), 129.277 (Ar-C), 129.176 (Ar-C), 128.907 (Ar-C), 128.499 (Ar-C), 128.402 (Ar-C), 127.391 (Ar-C), 126.879 (Ar-C), 124.121 (Ar-C), 122.741 (Ar-C), 121.698 (Ar-C), 120.571 (Ar-C), 111.761 (Ar-C), 109.432 (Ar-C).

\subsection{Refinement}

Crystal data, data collection and structure refinement details are summarized in Table 1 . All $\mathrm{H}$ atoms in the eight compounds (except for the $\mathrm{H}$ atoms on C35 in BDHMFI) were found in difference Fourier maps and then allowed to ride on their parent atoms. The location and isotropic displacement parameters of the $\mathrm{H}$ atoms on C35 in BDHMFI were refined freely.

\subsection{Cytotoxicity assays}

Human lung carcinoma A549 cells, mouse breast cancer $4 \mathrm{~T}_{1}$ cells, human MRC-5 lung normal cells and normal mouse NIH 3T3 fibroblasts were purchased from the Shanghai Cell Bank, Type Culture Collection Committee, Chinese Academy of Sciences. The cells were cultured in F12K medium supplemented with $10 \%$ heat-inactivated fetal bovine serum (FBS), $2 \mathrm{~m} M$ glutamine, $100 \mathrm{U} \mathrm{ml}^{-1}$ penicillin and $100 \mu \mathrm{g} \mathrm{ml}^{-1}$ streptomycin, and maintained at $310 \mathrm{~K}$ in a humidified atmosphere of $5 \% \mathrm{CO}_{2}$.

The cells (8000 cells) were seeded on 96-well microtiter plates in F12K medium with $10 \%$ FBS and incubated overnight. The cell culture medium was replaced by different doses of the compound solution, i.e. 1, 5, 10, 30, 50,100 and $150 \mu M$, and then the cells were cultured for another $72 \mathrm{~h}$. The MTT reagent was added to the cell supernatant for a final concentration of $0.5 \mathrm{mg} \mathrm{ml}^{-1}$ of MTT. After $3 \mathrm{~h}$, the cell culture medium was removed. Formazan crystals in adherent cells were dissolved in dimethyl sulfoxide (DMSO, $200 \mu \mathrm{l})$ and the absorbance of the formazan solution was measured. Each compound was tested in triplicate and the experiments were repeated three times.

Generally, the operations from cell culture to MTT assay for cell proliferation are the same as we reported before (Cheng $e t$ al., 2016; Bu et al., 2017; Tan et al., 2019).

\subsection{Molecular docking and quantum chemistry calculations}

Molecular docking studies of all eight Schiff bases with 18 potential target proteins were performed using the $S Y B Y L /$ Surflex-dock (Tripos, 2012) in order to screen the potential targets and illustrate the binding modes between proteins and ligands. All solvent molecules except those within $5 \AA$ around the natural ligand were removed from the protein structure. The molecular structures of the ligands were first extracted from the single-crystal X-ray structure and then optimized by employing density functional theory (DFT) at the B3LYP/6311+G(d,p) level (Becke, 1993; Lee et al., 1988; McLean \& Chandler, 1980; Krishnan et al., 1980). The default parameters were used regarding charges, bonds order and geometrical flexibility with no other constraints.

Except for the aforementioned structural optimizations, quantum chemistry calculations were also used to explore intermolecular interactions in the BMHFI crystal (see §3.1.5). Two methods, i.e. MP2/6-31G(d,p) and DFT/B3LYP/6-311G+ (d,p), were used (Møller \& Plesset, 1934; Rassolov et al., 2001; Frisch et al., 1984). The standard counterpoise method was applied to correct interaction energies for the basis set 
superposition error (BSSE) (Boys \& Bernardi, 1970). All geometries are extracted from the interacting pairs in the crystal of BMHFI without any structural relaxation.

All calculations were carried out using the GAUSSIAN03 program package (Frisch et al., 2004) on a Sunway BlueLight MPP supercomputer housed at the National Supercomputer Center in Jinan, China.

\section{Results and discussion}

\subsection{X-ray structures of the eight title compounds}

The identities of the conformations of the eight title compounds have been established through X-ray structure determinations, which clearly show the similarities and differences.

3.1.1. BDHFI. The monomeric structure of BDHFI is shown in Fig. 1(a), which indicates that the molecule contains a pair of linkage arms (the connection point is the $\mathrm{C} 1-\mathrm{C} 8$ bond axis). The pair of linkage arms crosses each other in an $\mathrm{X}$-shape; each arm has a similar conformation, i.e. the two
$\mathrm{C}=\mathrm{N}$ double bonds adopt the same $Z, E$ conformations in both arms. In fact, the other three di-Schiff bases (BDHAI, BDHMFI and BDHFN) reported in this article are X-shaped molecules and the two X-shaped arms in BDHFN are exactly the same (see \$3.1.4).

Both arms in BDHFI are rather flat. One arm consists of atoms $\mathrm{C} 1-\mathrm{C} 7 / \mathrm{N} 1 / \mathrm{N} 2 / \mathrm{C} 24-\mathrm{C} 31 / \mathrm{N} 6 / \mathrm{C} 32$ and all 19 non-H atoms are essentially coplanar, with an average r.m.s. deviation of only $0.0811 \AA$ and the largest r.m.s. deviation of $-0.1435 \AA$ occurring for atom N6. In another arm, all 19 non-H atoms are slightly less coplanar, with an average r.m.s. deviation of $0.1742 \AA$ (the largest r.m.s. deviation of $0.3027 \AA$ occurs for atom N5). The dihedral angle between the planes of these two arms is about $89.3^{\circ}$.

In the packing structure of BDHFI, three kinds of dominant noncovalent interactions (NCIs), including hydrogen bond a (Fig. $1 b$ ), $\mathrm{C}-\mathrm{H} \cdots \pi$ interaction b (Fig. $1 b$ ) and $\pi-\pi$ packing $\mathbf{c}$ (Fig. 1c), can be found with the help of PLATON (Tables S1S3 in the supporting information). The CrystalExplorer17 program (Hirshfeld, 1977; Turner et al., 2017) was used to

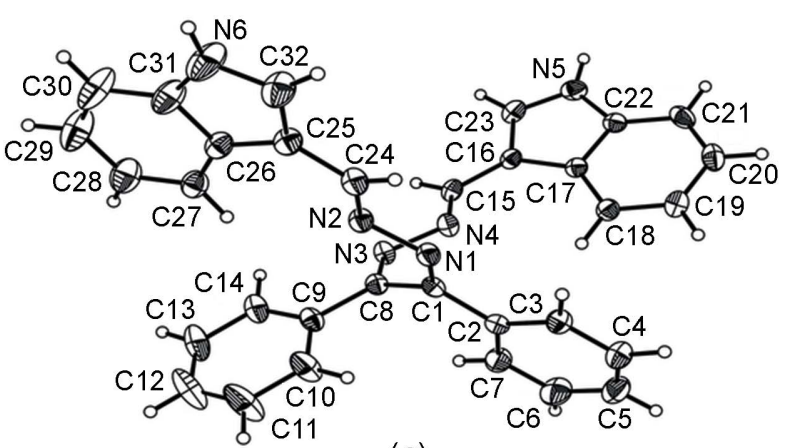

(a)

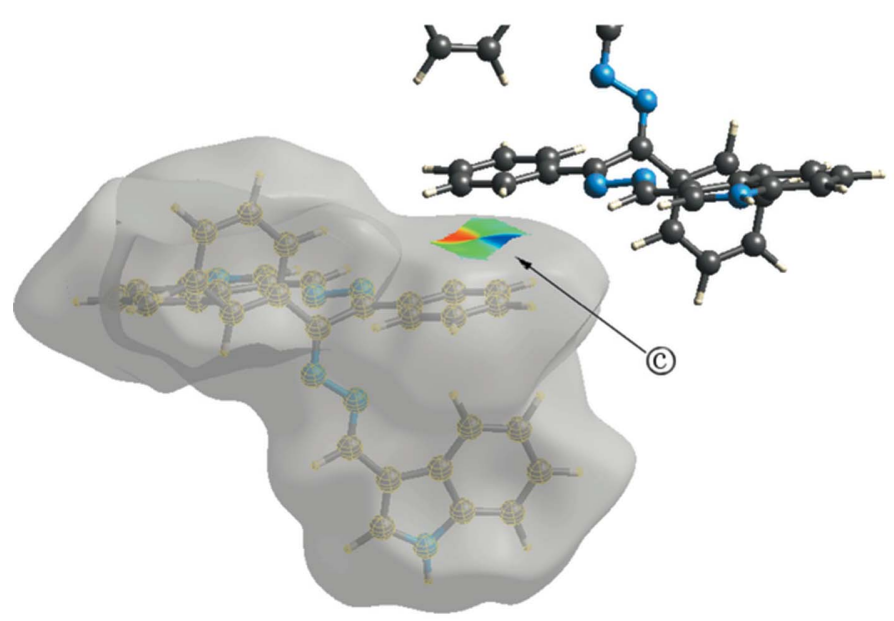

(c)

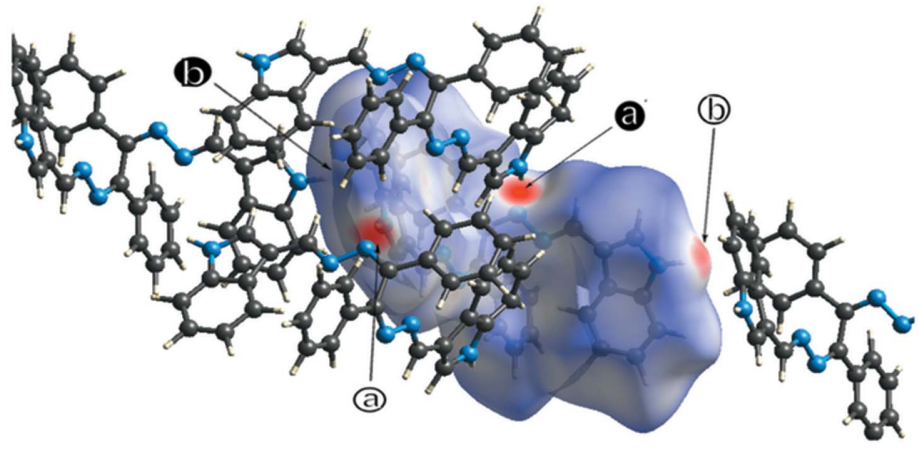

(b)

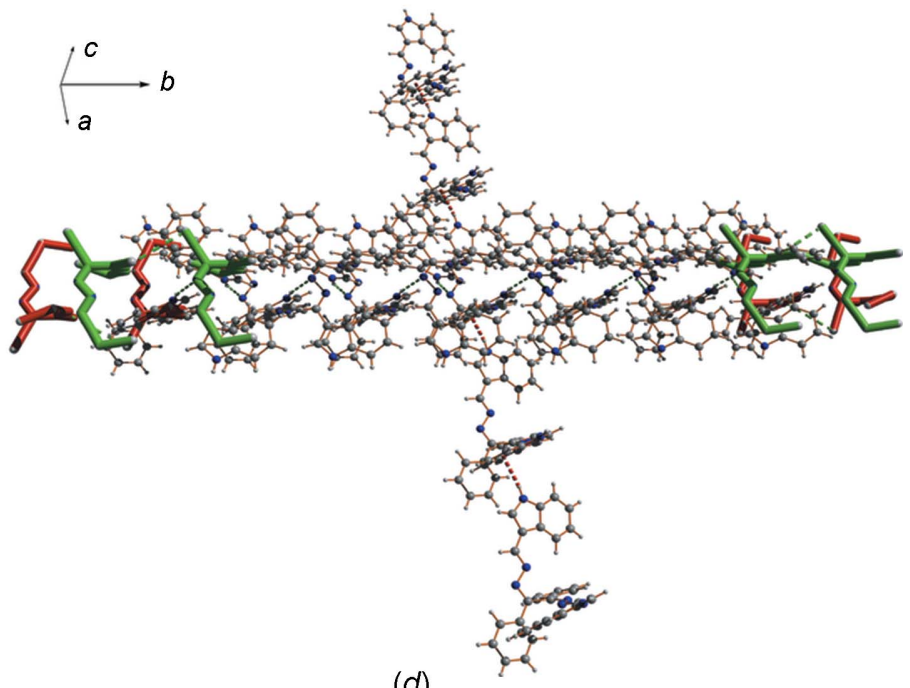

(d)

Figure 1

(a) The molecular structure of BDHFI, showing the atom-labelling scheme, with displacement ellipsoids for non- $\mathrm{H}$ atoms drawn at the $30 \%$ probability level at $293 \mathrm{~K}$. (b) The Hirshfeld surface for BDHFI, mapped over $d_{\text {norm }}$ ( -0.10 to $1.40 \AA$, same throughout this article). Four red spots correspond to

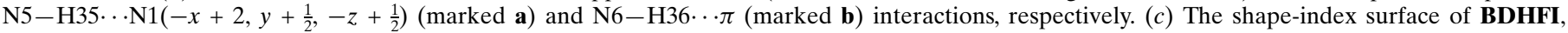
identifying $\pi-\pi$ stacking interactions (marked c). Only red and blue triangles on the surface are shown for clarity. $(d)$ Hydrogen bonds a (green dashed lines) and $\mathbf{b}$ (red dashed lines) link molecules into infinite 1D chains parallel to the crystallographic $b$ and $a$ axes, respectively, viewed along the crystallographic $[8, \overline{1}, 17]$ direction. Eight molecules are illustrated by the simplified structure (centre of gravity) for clarity and the two colours (red and green) represent two different orientations. 
verify the strength of these NCIs. It is worth noting that the geometries of all NCIs, including these very weak ones, calculated by PLATON are listed in the supporting information for all eight compounds reported in this article (Tables S1-S21 in the supporting information). But only those strong NCIs that can be verified by CrystalExplorer17 will be analysed. For the convenience of description, different kinds of strong NCIs are simplified into various notations (the first column in Tables S1-S21 in the supporting information). These weak intermolecular NCIs and all intramolecular NCIs are not coded because they make less contribution to the packing structure. For example, the $\mathrm{C} 3-\mathrm{H} 3 \cdots \mathrm{N} 3(x, y-1, z)$ hydrogen bond (Table $\mathrm{S} 1$ in the supporting information) is not coded because its role is not apparent in the Hirshfeld surface analysis (Fig. 1b). In rare cases, some 'strong' interactions verified by CrystalExplorer17 have not been suggested by

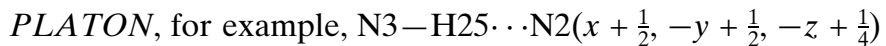
and $\mathrm{C} 24-\mathrm{H} 24 A \cdots \mathrm{O} 1(x+1, y, z)$ in Fig. 6(b) (see \$3.1.6), and $\mathrm{C} 11-\mathrm{H} 11 \cdots \mathrm{N} 1\left(x,-y-\frac{1}{2}, z-\frac{1}{2}\right)$ in Fig. 7(b) (see \$3.1.7). Their roles will not be analysed.

Hydrogen bonds a and b link BDHFI molecules into onedimensional (1D) chains parallel to the $b$ and $a$ axes, respectively (Fig. $1 d$ ), while $\pi-\pi$ interaction $\mathbf{c}$ links two molecules into a dimer. These chains and dimers serve as the main building blocks for the three-dimensional (3D) structures with the aid of other kinds of NCIs, such as van der Waals.

It should be mentioned that all the molecules in BDHFI adopt two relative orientations, which are highlighted with red and green colours, respectively (Fig. 1d). If these two relatively small arene rings in one molecule are omitted, the $\mathrm{X}$-shaped molecule can be regarded as a V-shaped one. These V-shaped molecules open towards entirely opposite directions: the red

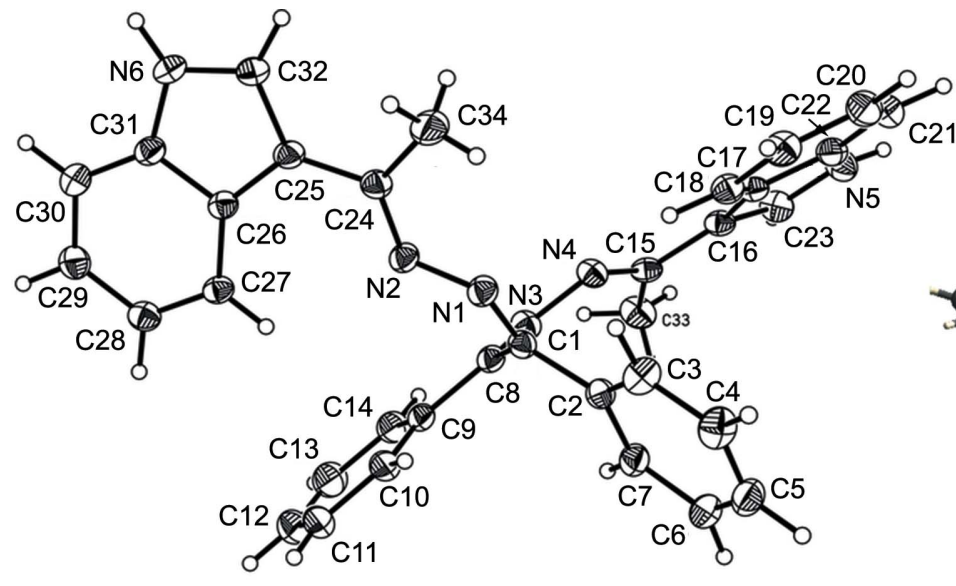

(a)

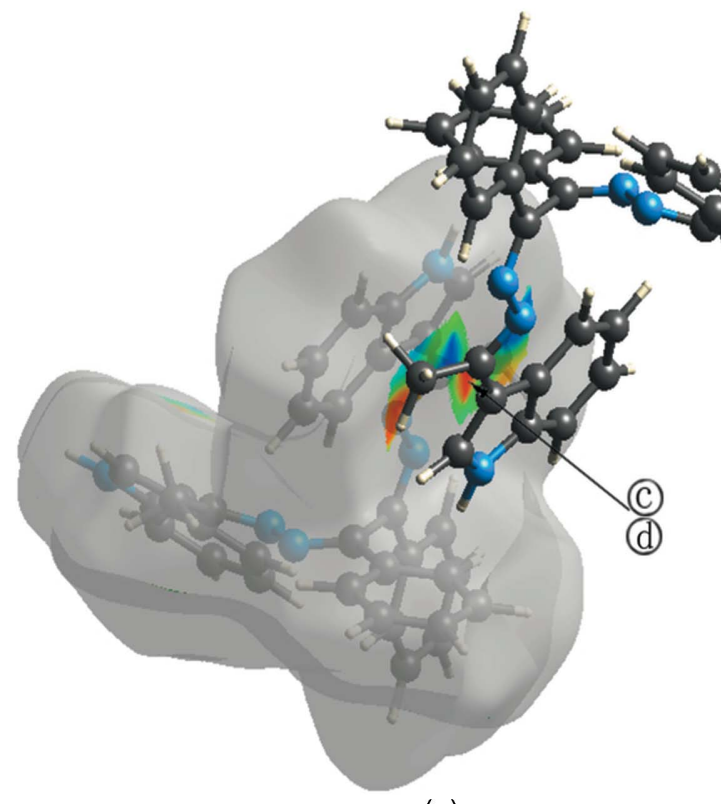

(c)

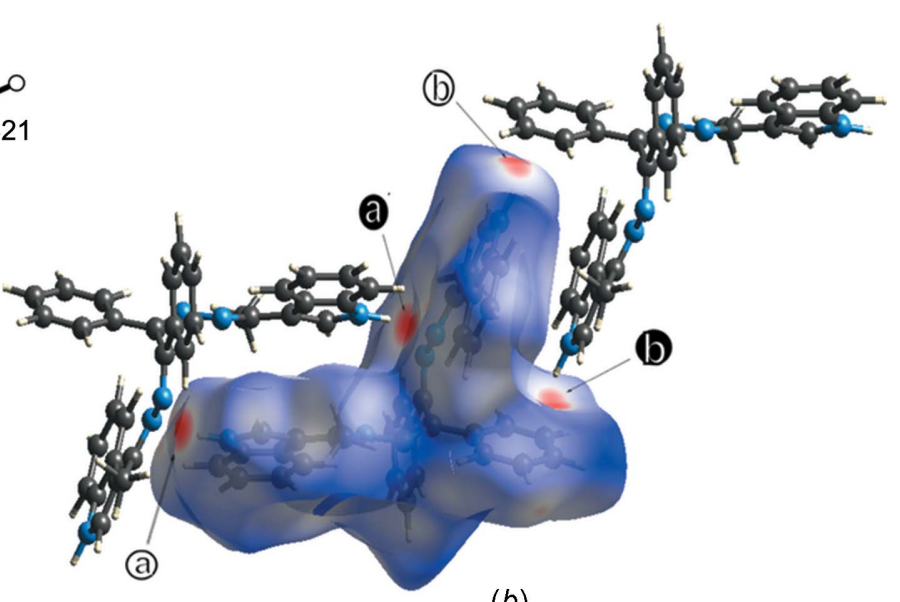

(b)

Figure 2

(a) The molecular structure of BDHAI, showing the atom-labelling scheme, with displacement ellipsoids for non- $\mathrm{H}$ atoms drawn at the $30 \%$ probability level at 293 K. $(b)$ The Hirshfeld surface for BDHAI, mapped over $d_{\text {norm. }}$. Four red spots correspond to N6 $-\mathrm{H} 36 \cdots \mathrm{N} 4(-x,-y+1,-z+1)(\mathrm{marked} \mathbf{a})$ and N5 $-\mathrm{H} 35 \cdots \pi$ (marked $\mathbf{b}$ ) interactions, respectively. (c) The shape-index surface of BDHAI, identifying $\pi-\pi$ stacking interactions (marked $\mathbf{c}$ and $\mathbf{d}$ ). Only red and blue triangles on the surface are shown for clarity. (d) Four kinds of NCIs, i.e. a, b, c and d (shown with red, green, purple and yellow dashed lines, respectively), link BDHAI molecules into an infinite 1D chain extending roughly along the [11 $\overline{1}]$ direction, viewed along the [7, $\overline{3}, 7]$ direction. 
ones are directed toward the positive half of the $c$ axis, while the green ones are directed toward the negative half (both roughly). Interestingly, the molecules in the other three diSchiff bases have two similar orientations, so there also exist red and green highlighted molecules in Figs. 2, 3 and 4. While molecules in the four mono-Schiff bases (BMHFI, BMHAI, BMHMFI and BMHFN) have four or eight orientations, mostly because of the two apparently asymmetrical arms (see $\S 3.1 .5$ to $\$ 3.1 .8$ ).

3.1.2. BDHAI. Similar to BDHFI, BDHAI is an X-shaped molecule with both arms being somewhat flat. But the coplanarity is worse than in BDHFI. In one arm, consisting of atoms $\mathrm{C} 1-\mathrm{C} 7 / \mathrm{N} 1 / \mathrm{N} 2 / \mathrm{C} 24-\mathrm{C} 31 / \mathrm{N} 6 / \mathrm{C} 32 / \mathrm{C} 34$, the average r.m.s. deviation is $0.3698 \AA$ and the largest r.m.s. deviation of $0.8308 \AA$ occurs for atom C7. In another arm, all 20 non- $\mathrm{H}$ atoms have an average r.m.s. deviation of $0.2542 \AA$ and the largest r.m.s. deviation of $0.4662 \AA$ occurs for atom N5. The dihedral angle between the planes of the two arms is about 98.0 (Fig. 2a).

In the packing structure of BDHAI, the most important four NCIs link molecules into dimers independently (Tables
S4-S6 in the supporting information). Hydrogen bonds a link two molecules into a dimer (Figs. $2 b$ and $2 d$ ), while b, $\mathbf{c}$ and $\mathbf{d}$ link two molecules into another dimer (Figs. $2 b, 2 c$ and $2 d$ ), whether they are used separately or collectively. But $\mathbf{a}, \mathbf{b}, \mathbf{c}$ and d will crosslink molecules into infinite $1 \mathrm{D}$ chains if working together (Fig. 2d).

3.1.3. BDHMFI. The monomeric structure of BDHMFI is depicted in Fig. 3(a), which contains one complete BDHMFI molecule and a half acetonitrile molecule in the asymmetric unit. The half acetonitrile molecule lies on an inversion centre (atom C35, which resides on a centre of inversion at the origin) and was refined disordered into two parts with the siteoccupancy factors being fixed at 0.5 . The inversion operator will create two BDHMFI molecules and one complete acetonitrile molecule, which are linked together by hydrogen bonds a (Fig. $3 b$ ). By the way, a only occurs between BDHMFI and acetonitrile (Figs. $3 b$ and $3 d$ ).

These two arms of X-shaped BDHMFI have a similar coplanarity to that in BDHFI. In one arm, consisting of atoms $\mathrm{C} 1-\mathrm{C} 7 / \mathrm{N} 1 / \mathrm{N} 2 / \mathrm{C} 24-\mathrm{C} 31 / \mathrm{N} 6 / \mathrm{C} 32 / \mathrm{C} 34$, the average r.m.s. deviation is $0.1063 \AA$ and the largest r.m.s. deviation of $0.1870 \AA$

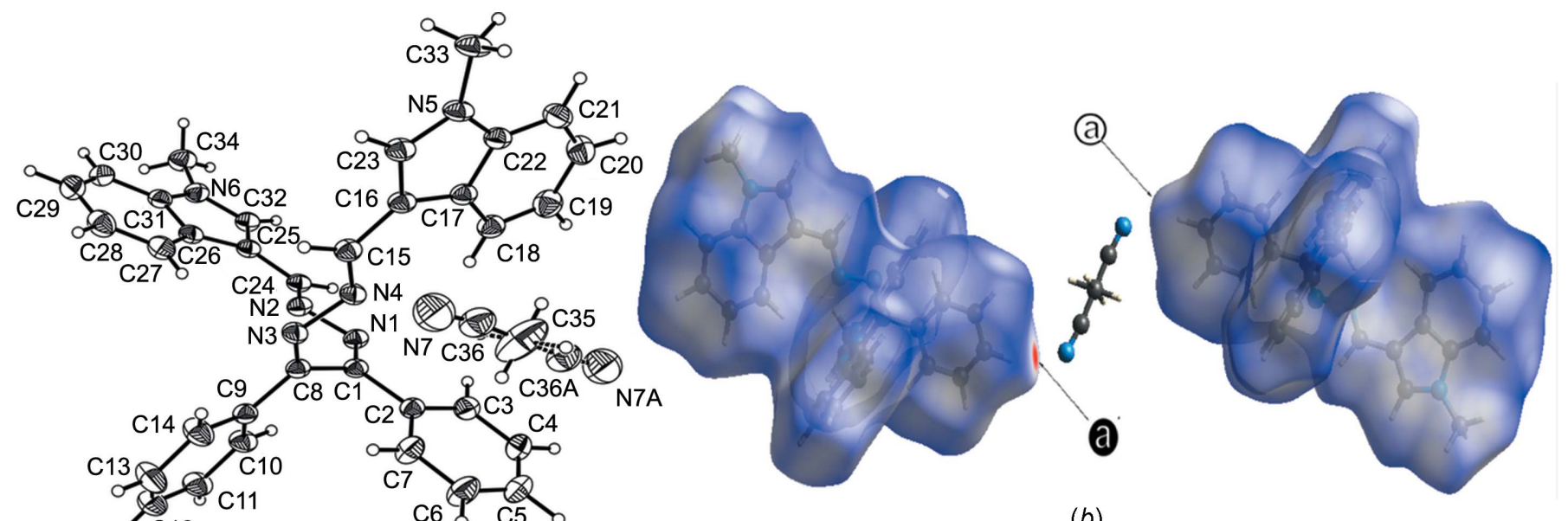

(a)

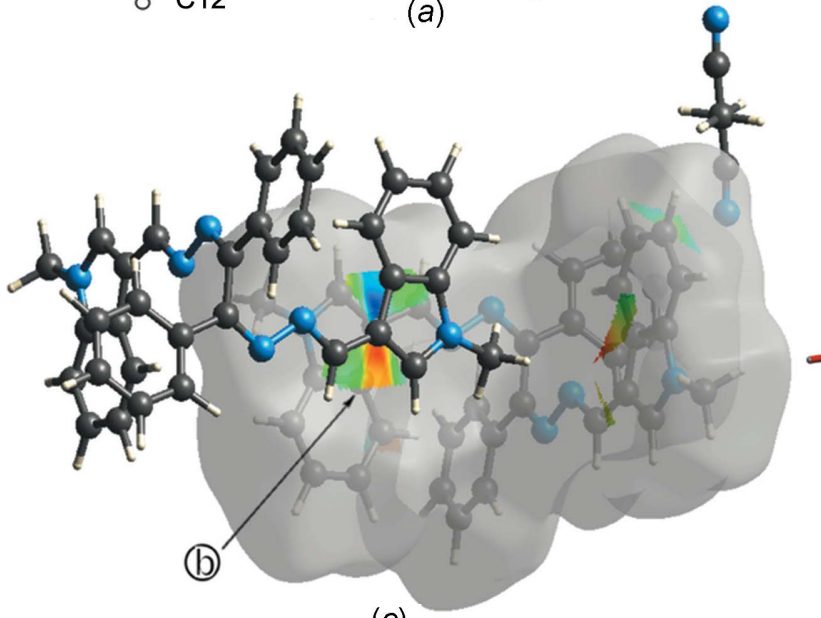

(b)
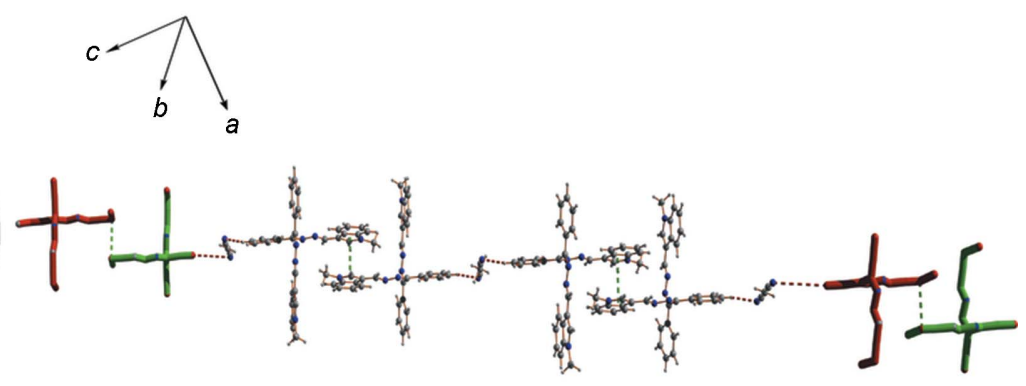

(d)

Figure 3

(a) The molecular structure of BDHMFI, showing the atom-labelling scheme, with displacement ellipsoids for non- $\mathrm{H}$ atoms drawn at the $30 \%$ probability level at $293 \mathrm{~K}$ [symmetry code: (A) $-x+2,-y,-z$ ]. (b) The dimer structure formed by two BDHMFI molecules and one disordered acetonitrile molecule through hydrogen bonds a (two red spots on the $d_{\text {norm }}$ Hirshfeld surface). (c) The shape-index surface of BDHMFI, identifying $\pi-\pi$ stacking interaction b. Only red and blue triangles on the surface are shown for clarity. $(d)$ NCIs a and b (shown with red and green dashed lines, respectively) link BDHMFI molecules into an infinite $1 \mathrm{D}$ chain extending roughly along the $[10 \overline{3}]$ direction, viewed along the $[1,9, \overline{5}]$ direction. 
occurs for atom C6. In another arm, all 20 non-H atoms have an average r.m.s. deviation of $0.1964 \AA$ and the largest r.m.s. deviation of $0.4540 \AA$ occurs for atom C33. The dihedral angle between the planes of these two arms is about $90.6^{\circ}$.

Either hydrogen bond $\mathbf{a}$ or $\pi-\pi$ interaction $\mathbf{b}$ links two adjacent BDHMFI molecules into dimers, but they are not the same dimer (Figs. $3 b$ and $3 c$ ). If $\mathbf{a}$ and $\mathbf{b}$ collaborate together, $1 \mathrm{D}$ chains extending along the crystallographic $[24,1, \overline{63}]$ direction will be formed (Fig. $3 d$ ).

3.1.4. BDHFN. The molecular structure of BDHFN is shown in Fig. 4(a), which is the result of a glide reflection along the crystallographic $c$ axis. That is to say, the asymmetric unit contains only one half BDHMFI molecule, which happened to be one arm of the X-shaped structure. The dihedral angle between the planes of the naphthalene and arene rings is $22.6(3)^{\circ}$ and the dihedral angle between the two symmetryrelated arms is $85.1(4)^{\circ}$.
The only kind of hydrogen bond is intramolecular interactions in the packing structure of BDHFN (Table S10 in the supporting information). Besides van der Waals, only one kind of intermolecular $\pi-\pi$ interaction a plays an important role (Table S11 in the supporting information), which accounts for merely $6.1 \%$ of the Hirshfeld surface (Fig. $4 b$ ). That is to say, it is van der Waals interactions that play a critical role in the crystal molecular assembly. As for $\pi-\pi$ interactions a (Fig. $4 c$ ), they help to link BDHFN molecules into 1D lines parallel to the crystallographic $c$ axis (Fig. $4 d$ ).

3.1.5. BMHFI. The molecular structure of BMHFI is shown in Fig. 5(a), which indicates that the molecule still contains a pair of linkage arms, but one arm is shorter than the other because one $\mathrm{C}=\mathrm{O}$ group has not been converted into a Schiff base. The longer arm has a similar conformation to that in its corresponding di-Schiff base BDHFI, i.e. these two $\mathrm{C}=\mathrm{N}$ double bonds adopt the same $Z, E$ conformations. In fact, all

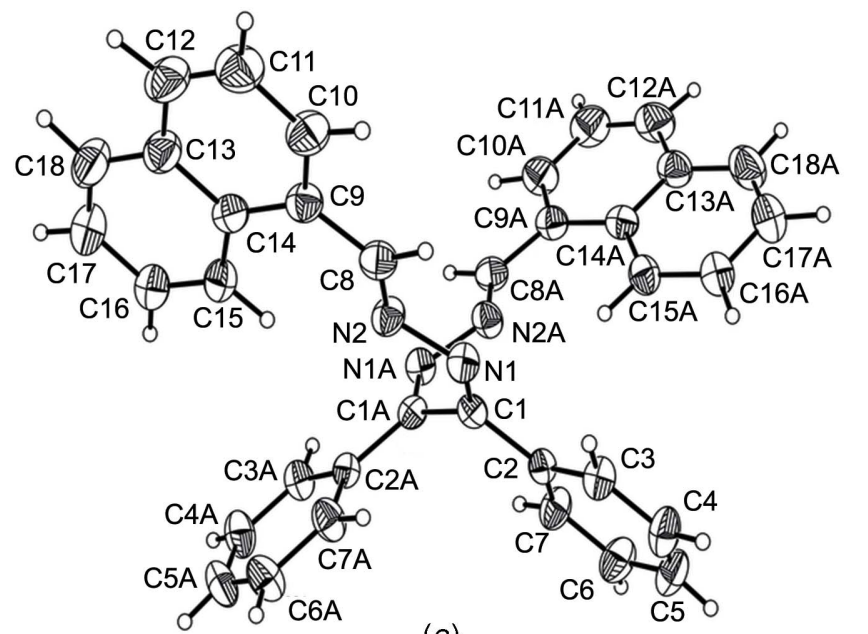

(a)

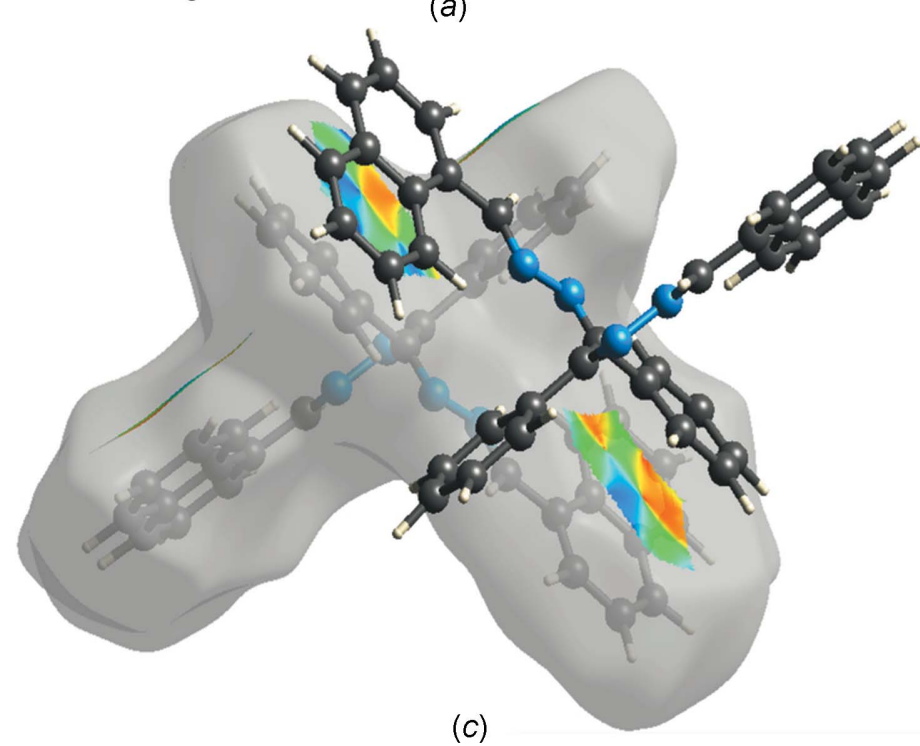

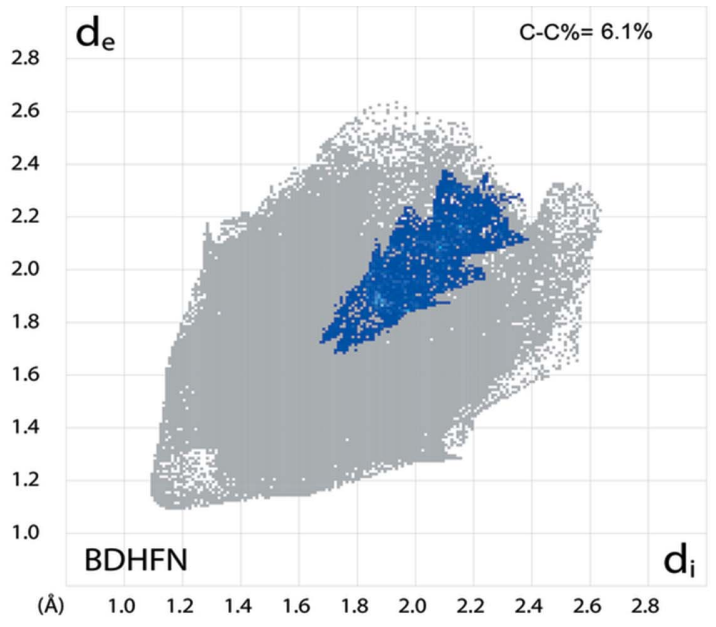

(b)

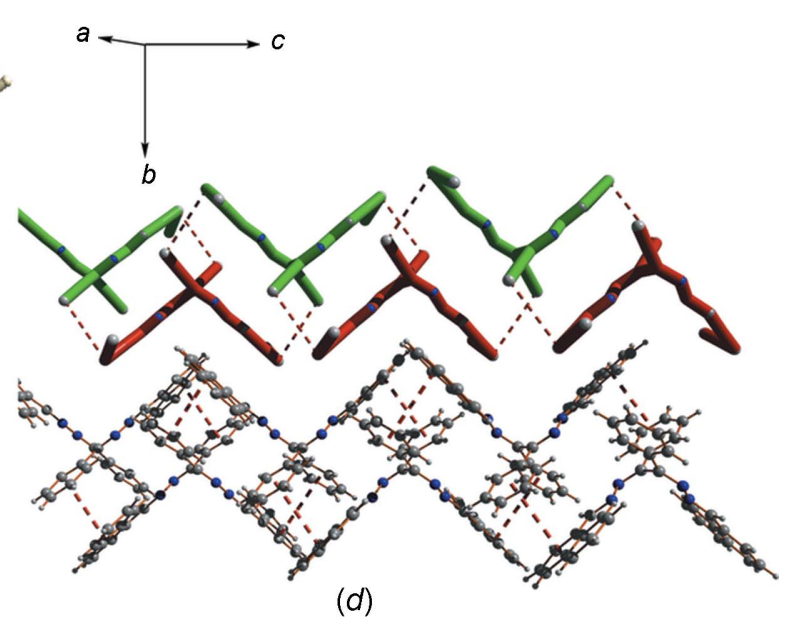

Figure 4

(a) The molecular structure of BDHFN, showing the atom-labelling scheme, with displacement ellipsoids for non-H atoms drawn at the $30 \%$ probability level at $293 \mathrm{~K}$ [symmetry code: (A) $-x, y,-z+\frac{1}{2}$ ]. (b) The contribution of $\mathrm{C} \cdots \mathrm{C}$ contacts in the $2 \mathrm{D}$ fingerprints of BDHFN, indicating $\pi-\pi$ interaction a. (c) The shape-index surface of BDHFN, identifying $\pi-\pi$ stacking interaction a (not marked as there is only one type of interaction). (d) $1 \mathrm{D}$ chains formed by $\pi-\pi$ stacking interaction a (shown with red dashed lines), viewed along the [501] direction. The upper one is illustrated by the simplified structure (centre of gravity). 
eight Schiff bases reported in this paper adopt similar $Z, E$ conformations.

As a whole, both arms in BMHFI are flat. The long arm has an average r.m.s. deviation of $0.2242 \AA$ and the largest r.m.s. deviation of $-0.3858 \AA$ occurs for N3. The short arm has much better coplanarity, with an average r.m.s. deviation of only $0.0160 \AA$ (the largest r.m.s. deviation of $-0.0647 \AA$ occurs for O1). The dihedral angle between the two arms is about $93.8^{\circ}$.
In the packing structure of BMHFI, two kinds of intermolecular hydrogen bonds (a and b) (Table S12 in the supporting information) link molecules into 1D chains parallel to the crystallographic $a$ axis, whether they are used separately or collectively. Unlike its corresponding di-Schiff base BDHFI, BMHFI adopts four relative orientations, which are highlighted in red, green, purple and blue (Figs. $5 c$ and $5 d$ ). It should be noted that the colour intensity of the vivid spot
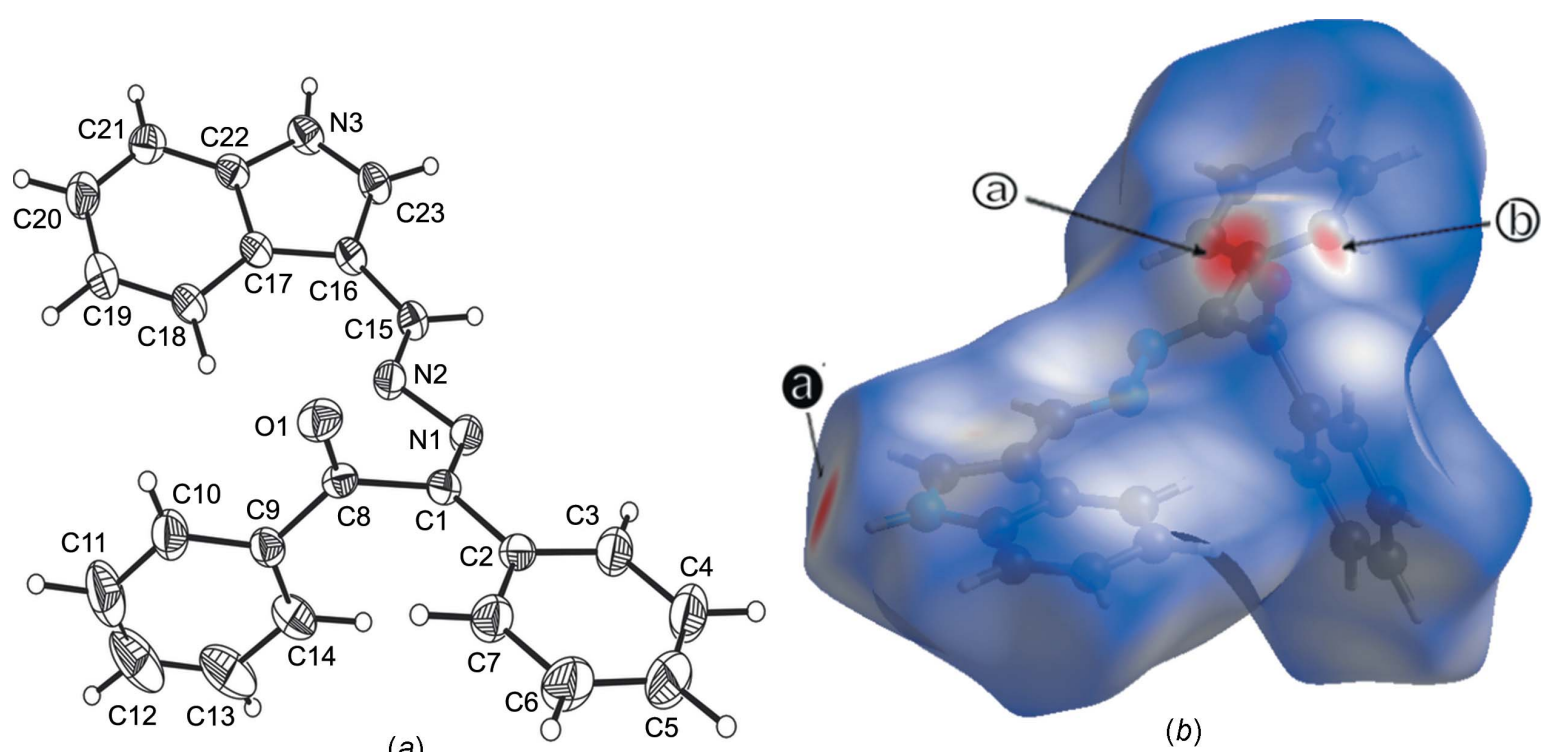

(a)
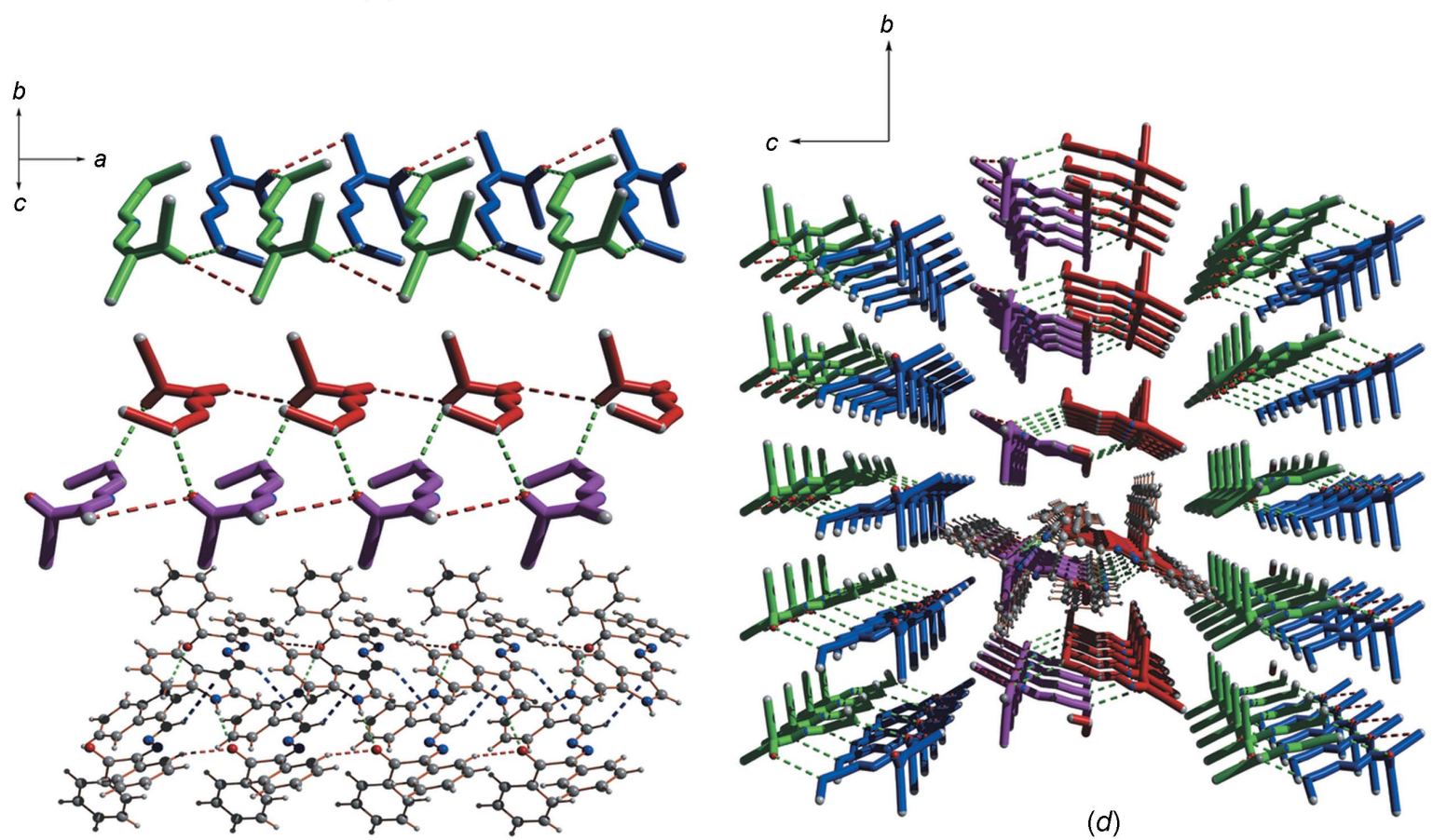

(c)

Figure 5

(a) The molecular structure of BMHFI, showing the atom-labelling scheme, with displacement ellipsoids for non- $\mathrm{H}$ atoms drawn at the $30 \%$ probability

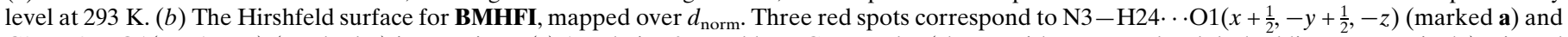
$\mathrm{C} 3-\mathrm{H} 3 \cdots \mathrm{O} 1(x+1, y, z)($ marked b) interactions. (c) 1D chains formed by NCIs a and b (shown with green and red dashed lines, respectively), viewed perpendicular to the extending direction, i.e. the $a$ axis. The upper two lines are illustrated by the simplified structure (centre of gravity). (d) $1 \mathrm{D}$ chains formed by the aforementioned NCIs a and $\mathbf{b}$, viewed along the extending direction, i.e. the $a$ axis, aiming to show the packing mode of four different orientations (simplified structure with four different colours). 
representing hydrogen bond $\mathbf{a}$ is very high, indicating a strong hydrogen bond. Thus, the intermolecular interaction energy with the BSSE correction has been calculated using the MP2/ 6-31G $(d, p)$ and B3LYP/6-311G+ $(d, p)$ methods on the basis of dimer geometries extracted from the crystal structure. The calculated interaction energies for $\mathbf{a}$ and $\mathbf{b}$ are -50.97 and $-19.92 \mathrm{~kJ} \mathrm{~mol}^{-1}$ (MP2), and -19.71 and $-4.25 \mathrm{~kJ} \mathrm{~mol}^{-1}$ (DFT), respectively, indicating a much stronger favourable binding energy for a than that for $\mathbf{b}$, which agrees with the colour intensity in the $d_{\text {norm }}$ map (Fig. $5 b$ ).

3.1.6. BMHAI. The 'long arm' in BMHAI assumes less coplanarity than that in BMHFI, and even less than that in BDHAI, which can be deduced from the dihedral angles between the indole and arene rings (Fig. $6 a$ ). In BMHFI, the value is $20.4(4)^{\circ}$, while in BDHAI, the dihedral angles are 23.6 (4) and $39.9(5)^{\circ}$, but in BMHAI, this value is increased to $54.5(3)^{\circ}$.

There are eight kinds of molecular orientations and one kind of intermolecular hydrogen bond, i.e. a, in the crystal structure of BMHAI (Figs. $6 b$ and $6 c$ ) (Tables S15-S17 in the supporting information). Hydrogen bonds a link molecules into two kinds of $1 \mathrm{D}$ chains, one is parallel to the crystallographic $a$ axis (these molecules are simplified into green, blue, yellow and indigo skeletons in Fig. $6 c$ ) and the other is parallel to the $b$ axis (these molecules are simplified into orange, red, purple and violet skeletons in Fig. $6 c$ ).

3.1.7. BMHMFI. Both the 'long arm' and the 'short arm' in BMHMFI have good coplanarity. The dihedral angle between

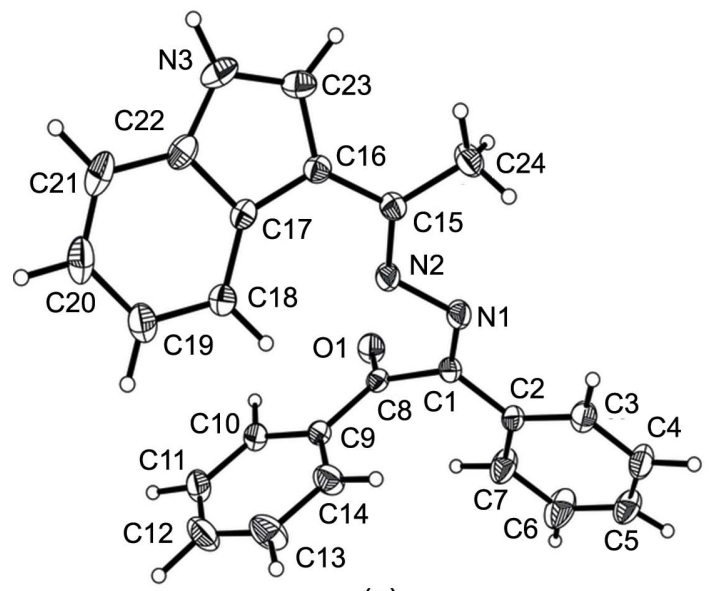

(a)

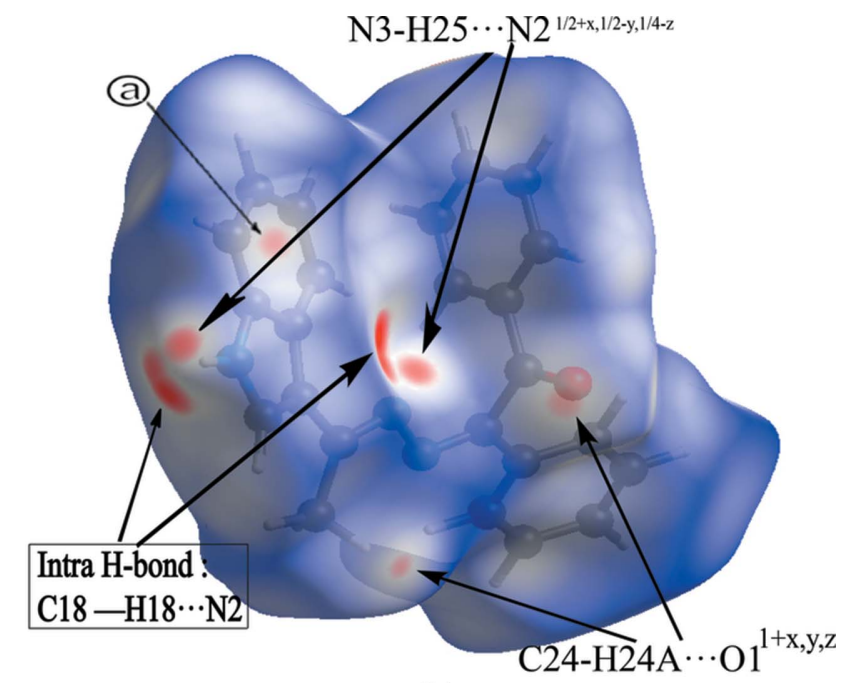

(b)

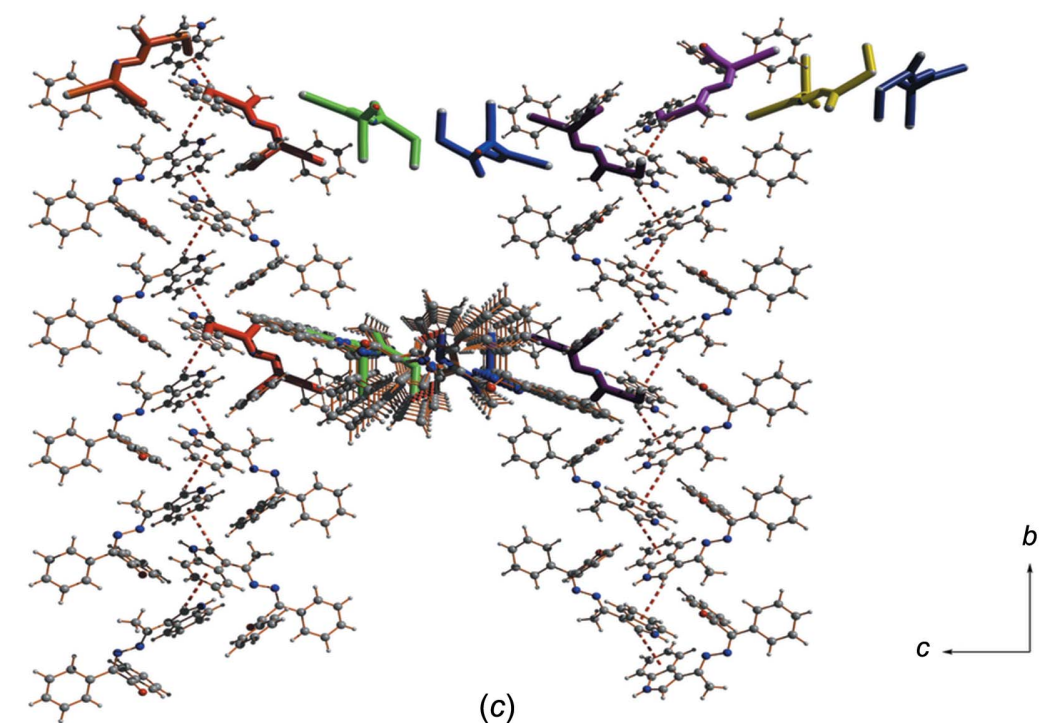

Figure 6

(a) The molecular structure of BMHAI, showing the atom-labelling scheme, with displacement ellipsoids for non-H atoms drawn at the $30 \%$ probability level at $293 \mathrm{~K}$ [symmetry code: (A) $-x, y,-z+\frac{1}{2}$ ]. (b) The Hirshfeld surface for BMHAI, mapped over $d_{\text {norm. }}$. Three kinds of intermolecular hydrogen bonds and one kind of intramolecular hydrogen bond can be visualized as red spots, but only hydrogen bond a was confirmed by the PLATON program (Spek, 2009). (c) 1D chains along the $a$ and $b$ axes formed by the aforementioned hydrogen bonds a (shown with red dashed lines), viewed along the $a$ axis, aiming to show the packing mode of the eight different orientations as a simplified structure with eight different colours, i.e. orange, red, green, blue, purple, violet, yellow and indigo. 
the planes of the indole and arene rings in the 'long arm' is only $14.0(2)^{\circ}$. The long arm has an average r.m.s. deviation of $0.1492 \AA$ and the largest r.m.s. deviation is $0.3816 \AA$ for atom C24; the short arm has an average r.m.s. deviation of only $0.0324 \AA$ and the largest r.m.s. deviation is $0.1135 \AA$ for atom O1. These two arms are roughly perpendicular to each other, with a dihedral angle of 91.1 (3) (Fig. 7a).

The most intense red spots represent a $\mathrm{C} 23-\mathrm{H} 23 \ldots$ $\operatorname{ring}(\mathrm{C} 17-\mathrm{C} 22)\left(-x+1, y+\frac{1}{2},-z+\frac{1}{2}\right)$ interaction, coded as a (Fig. $7 b$ ) (Table S18 in the supporting information), which links molecules into a 1D chain parallel to the $b$ axis (Fig. 7d). The second intense spot represents a $\mathrm{C} 11-\mathrm{H} 11 \cdots \mathrm{N} 1(x$, $-y-\frac{1}{2}, z-\frac{1}{2}$ ) hydrogen bond (Fig. $7 b$ ), which was not suggested by PLATON. Thus, its role in the packing structure will not be analysed in this article. Two kinds of intermolecular $\pi-\pi$ interactions (b and $\mathbf{c}$ ) always co-exist (Fig. $7 c$ ) (Table S19 in the supporting information), and they link two adjacent molecules into a dimer (Fig. 7d). The collaboration of $\mathbf{a}, \mathbf{b}$ and c links molecules into a 2D layer structure (Fig. 7d).

3.1.8. BMHFN. The dihedral angle between the planes of the naphthalene and benzene rings in the 'long arm' is $24.2(5)^{\circ}$. The dihedral angle between the long and short arms is about $81.4(5)^{\circ}$ (Fig. $8 a$ ).

There are four kinds of molecular orientations and four kinds of intermolecular NCIs $(\mathbf{a}, \mathbf{b}, \mathbf{c}$ and $\mathbf{d})$ in the crystal structure of BMHFN (Figs. $8 b, 8 c$ and $8 d$ ) (Tables S20 and S21 in the supporting information). Hydrogen bond a links molecules into 1D chains parallel to the crystallographic $b$ axis (Figs. $8 b$ and $8 d$ ). Among these three types of $\pi-\pi$ stacking interactions, $\mathbf{b}$ and $\mathbf{d}$ always co-exist and link molecules into 1D chains parallel to the crystallographic $c$ axis (Figs. $8 c$ and $8 d$ ), $\mathbf{c}$ joins two molecules (red and green, and blue and yellow;

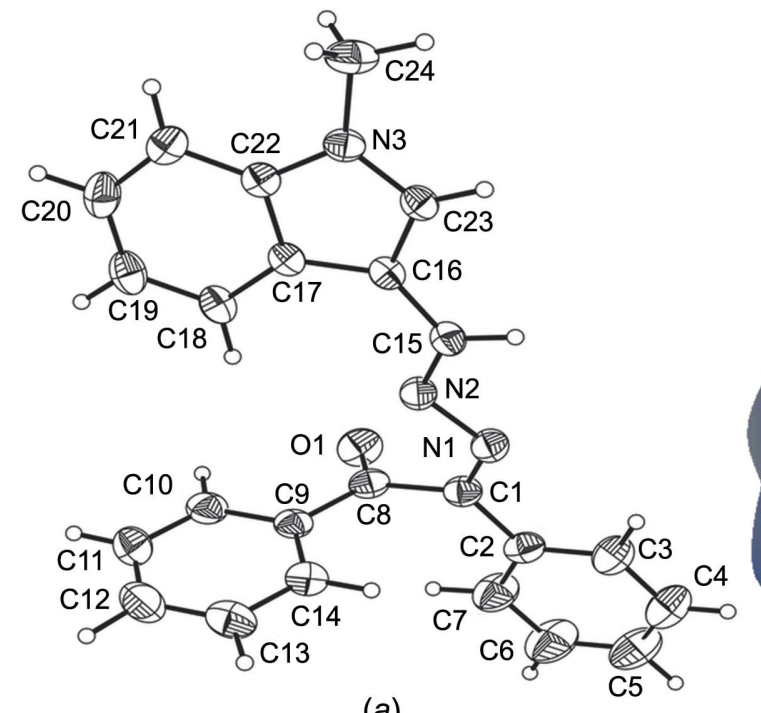

(a)

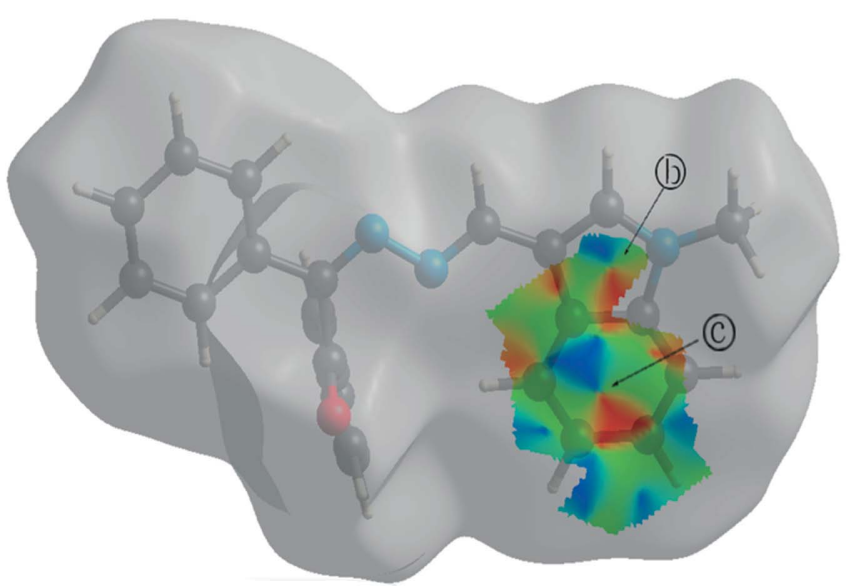

(c)

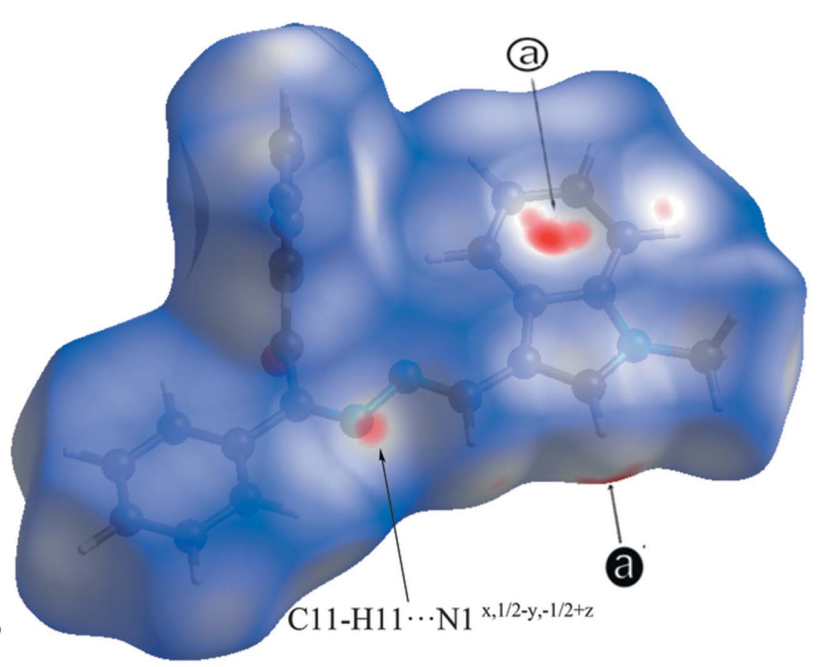

(b)

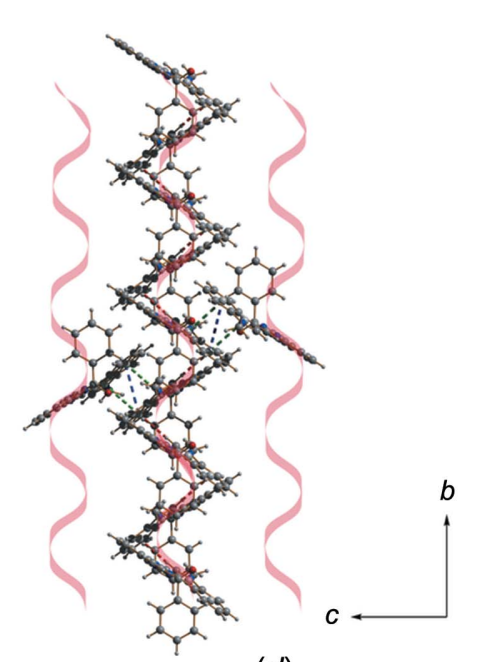

(d)

Figure 7

(a) The molecular structure of BMHMFI, showing the atom-labelling scheme, with displacement ellipsoids for non- $\mathrm{H}$ atoms drawn at the $30 \%$ probability level at $293 \mathrm{~K}$. (b) The Hirshfeld surface for BMHMFI, mapped over $d_{\text {norm }}$. The intermolecular hydrogen bonds a calculated using PLATON,

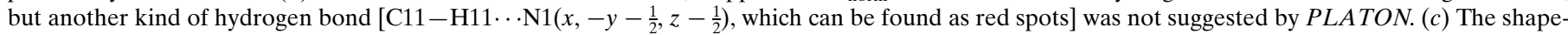
index surface of BMHMFI, identifying $\pi-\pi$ stacking interactions $\mathbf{b}$ and $\mathbf{c}$. $(d) 1 \mathrm{D}$ chains formed by $\mathrm{C}-\mathrm{H} \cdots \pi$ interactions $\mathbf{a}$ (shown with red dashed lines) can be woven into a 2D layer structure by $\pi-\pi$ interactions $\mathbf{b}$ and $\mathbf{c}$ (shown with green and blue dashed lines, respectively), viewed along the $a$ axis. 
Fig. $8 d$ ) into dimers. The co-operation of all three types of $\pi-\pi$ stacking interactions (b, c and d) links molecules into a $2 \mathrm{D}$ layer structure extending along the crystallographic (100) plane (Fig. 8d). In fact, all four kinds of intermolecular NCIs crosslink molecules into the same infinite 2D layer structure.

\subsection{Cytotoxicity assays - inhibition of lung and breast cancer} cell growth

To study the growth inhibitory effects of these eight Schiff bases on lung/breast cancer cells, we treated human A549 and mouse $4 \mathrm{~T}_{1}$ cells with the compounds and examined the growth of cells with an MTT assay. Meanwhile, MRC-5 normal lung cells and NIH 3T3 fibroblasts were also tested using the same method in order to evaluate the selective cytotoxicity of these new compounds. All experiments were carried out with cisplatin (a compound used as a chemotherapy drug to treat many types of cancers) for comparison. The cytotoxic activities as $50 \%$ inhibitory concentration $\left(\mathrm{IC}_{50}\right)$ values are shown in Table 2.

As we can see, both BDHFI and BDHAI have similar cytotoxic activities to the standard cisplatin for both cancer cell lines. All mono-Schiff bases show slightly weaker inhibi-

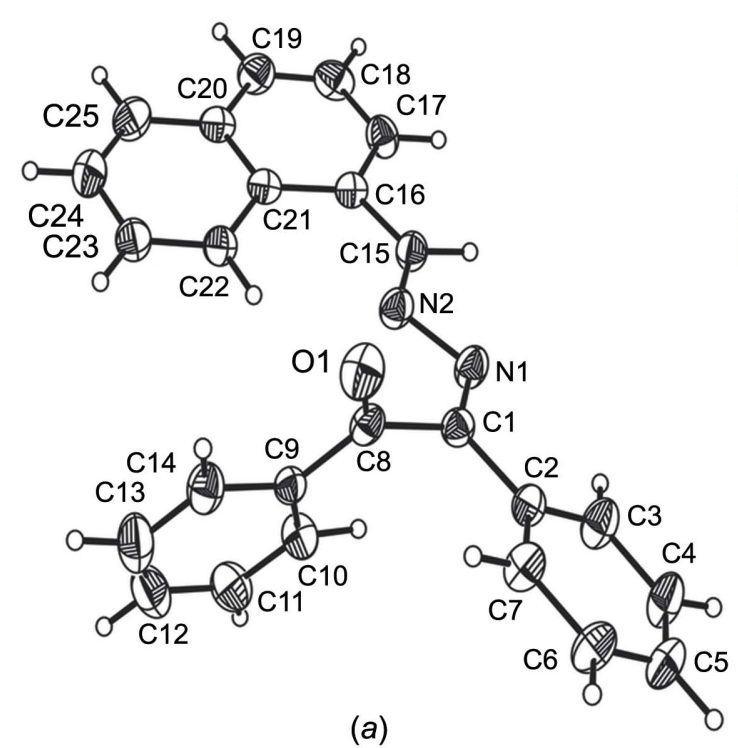

(a)

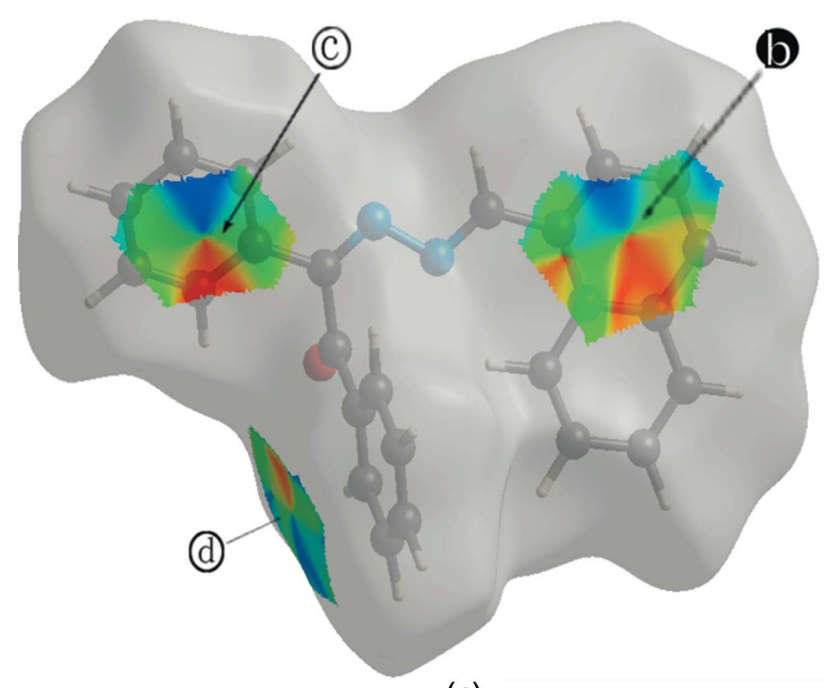

(c)

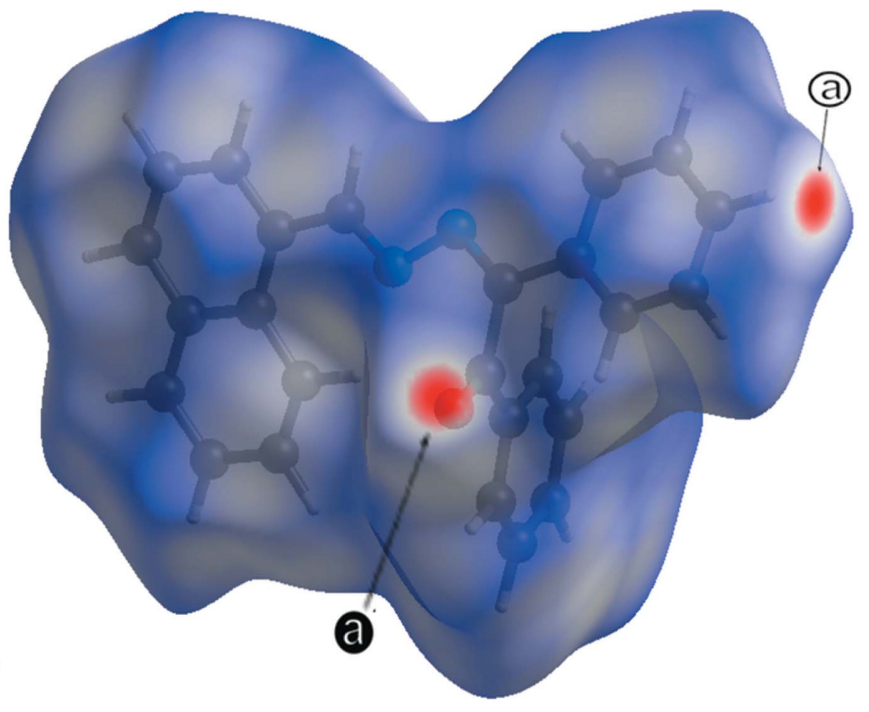

(b)

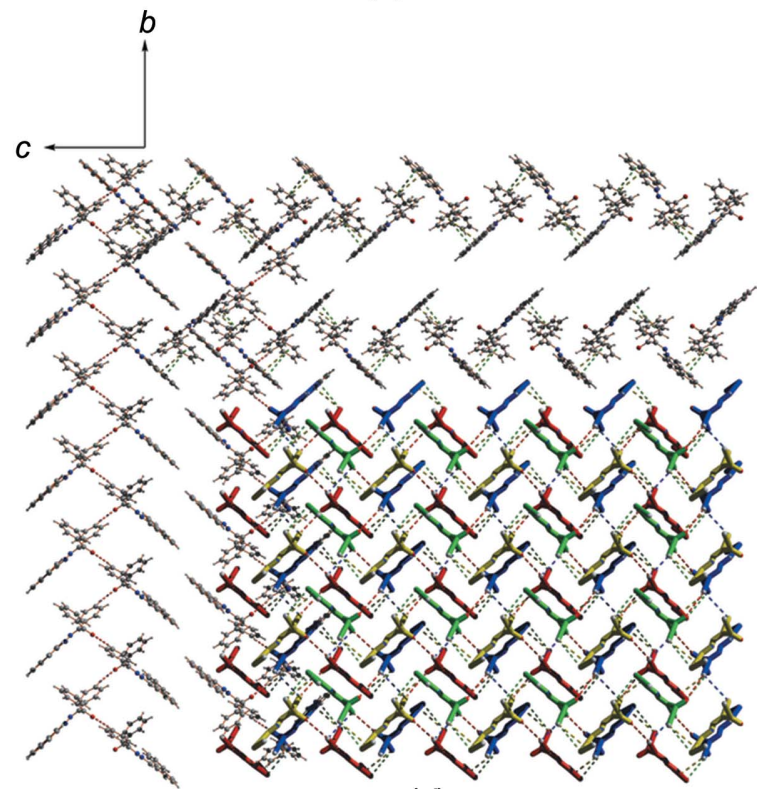

(d)

Figure 8

(a) The molecular structure of BMHFN, showing the atom-labelling scheme, with displacement ellipsoids for non-H atoms drawn at the $30 \%$ probability level at $293 \mathrm{~K}$. (b) The Hirshfeld surface for BMHFN, mapped over $d_{\text {norm }}$. Two red spots correspond to C5 $-\mathrm{H} 5 \cdots \mathrm{O} 1\left(-x+1, y-\frac{1}{2},-z+\frac{3}{2}\right)$ (marked a). (c) The shape-index surface of BMHFN, identifying $\pi-\pi$ stacking interactions $\mathbf{b}$, $\mathbf{c}$ and $\mathbf{d}$. Only red and blue triangles on the surface are shown for clarity. (d) 2D layer structure formed by NCIs a b, $\mathbf{c}$ and $\mathbf{d}$ (shown with red, green, blue and yellow dashed lines, respectively), viewed along the $a$ axis. Four discontinuous lines are shown, the left two (along the $b$ axis) are formed by NCI a and the top two (along the $c$ axis) are formed by NCIs $\mathbf{b}$ and $\mathbf{d}$. Molecules in the bottom right corner are illustrated by the simplified structure (centre of gravity), showing four kinds of orientations. 
Table 2

Inhibition of A549, 4T 1 , MRC-5 and NIH 3T3 cell growth by the title compounds compared with cisplatin $(\mu M)$.

\begin{tabular}{lcclc}
\hline Compound & $\mathrm{A} 549$ cells, $\mathrm{IC}_{50}$ & $4 \mathrm{~T}_{1}$ cells, $\mathrm{IC}_{50}$ & MRC-5 cells, IC 50 & NIH 3T3 fibroblasts, IC 50 \\
\hline BDHFI & $8.0 \pm 0.5$ & $7.5 \pm 0.5$ & $24.5 \pm 1.5$ & $29.5 \pm 1.0$ \\
BDHAI & $8.5 \pm 0.6$ & $7.0 \pm 0.6$ & $36.5 \pm 1.5$ & $>>150.0$ \\
BDHMFI & $125.0 \pm 1.0$ & $122.0 \pm 1.0$ & $>150.0$ & $>150.0$ \\
BDHFN & $130.0 \pm 1.0$ & $125.0 \pm 1.0$ & $88.0 \pm 1.5$ & $>150.0$ \\
BMHFI & $46.5 \pm 0.5$ & $32.5 \pm 0.5$ & $83.0 \pm 1.5$ & $85.0 \pm 1.5$ \\
BMHAI & $43.0 \pm 0.5$ & $30.0 \pm 0.5$ & $>150.0$ & $76.0 \pm 1.5$ \\
BMHMFI & $148.0 \pm 1.2$ & $141.0 \pm 1.0$ & $>150.0$ & $>150.0$ \\
BMHFN & $150.0 \pm 1.2$ & $148.0 \pm 1.0$ & $22.5 \pm 1.5$ & $>150.0$ \\
Cisplatin & $6.5 \pm 0.5$ & $0.5 \pm 0.1$ & $21.0 \pm 1.0$ \\
\hline
\end{tabular}

tory activity of A549 and $4 \mathrm{~T}_{1}$ compared with their corresponding di-Schiff bases. Incorporating a $\mathrm{CH}_{3}$ group at the $\mathrm{N}-\mathrm{H}$ position in the indole ring proved detrimental for anticancer activity (BDHMFI and BMHMFI), while substitution on the imine $\mathrm{C}$ atom has little effect (BDHAI and BMHAI). This might be due to the availability of enough space to accommodate a methyl group at this particular site of the inhibitor binding pocket, or the $\mathrm{N}-\mathrm{H}$ group favours combination with the hydrogen-bonding pocket. In one word, for BDHFI, BDHAI, BMHFI and BMHAI, the normal indole rings should contribute greatly to their cytotoxicities. When indole rings are changed into 1-methylindole or naphthalene, the cytotoxicity is greatly decreased.

As for the selective cytotoxicity between normal and malignant cells, MTT assays reveal a similar pattern to what were seen in our previous work (Tan et al., 2019). That is to say, all Schiff bases possess selective cytotoxicity on cancer cells over normal cells. But they have relevant inhibitory concentrations. The higher the $\mathrm{IC}_{50}$ value for selected malignant cells, the higher the value for responding normal cells. Among them, BDHFI, BDHAI, BMHFI and BMHAI displayed high potency and selectivity in all cell lines.

These experimental studies clearly predict cytotoxic activities of indole-containing Schiff bases. Such encouraging preliminary results confirm the feasibility and reliability of this excellent framework in the discovery of potent antitumour agents.

\subsection{Reverse docking studies for target fishing}

In order to find a few most possible molecular targets for these Schiff bases, Swiss Target Prediction web server (http:// www.swisstargetprediction.ch/) (Daina et al., 2019; Gfeller et $a l ., 2013)$ was used for the initial selection of potential targets. For each of these eight Schiff bases, 100 most potential targets were selected for further evaluation. Then cross screenings were carried out among these eight sets of potential targets based on the following method. Firstly, eight sets of targets were divided into two groups according to the antiproliferative activities of the Schiff bases. Four sets of potential targets related to BDHFI, BDHAI, BMHFI and BMHAI belong to group 1, and another four sets of potential targets related to BDHMFI, BDHFN, BMHMFI and BMHFN are group 2. Considering that all the Schiff bases in group 1 have a similar skeleton and have much higher activities than those in group 2, the targets in group 1 are probably the same, while the ligands in group 2 should not hit these targets. Technically, the most probable targets should be hit four times in group 1 and should not be hit in group 2. In our work, the targets that were hit four or three times in group 1 were selected (total of 32 targets) on account of random error in the prediction model. But if one target was also hit more than twice (including twice) in group 2, it should be removed (14 targets were removed). In the end, 18 targets remained for further screening through the reverse docking method.

As mentioned above, the initially assessed Rounds comprised a total of 18 targets. Only two of these targets do not have detailed 3D structural information, i.e. Neurokinin 2 receptor and Serotonin 6 (5-HT6) receptor. Thus, homology models built using the SWISS-MODEL server (https://swissmodel.expasy.org/) (Waterhouse et al., 2018; Bienert et al., 2017) and optimized by $S Y B Y L-X$ (Tripos, 2012) were used. The structure of Neurokinin 2 receptor was modelled on the bovine rhodopsin crystal structure (PDB ID: 1f88) as a template (Chandrashekaran et al., 2009), while the structure of the 5-HT6 receptor was modelled using the $\beta 2$ adrenergic receptor template (PDB ID: 4lde) (Łażewska et al., 2017) (Figs. S17 and S18 in the supporting information). Though the obtained models exhibit only limited accuracy, it has been demonstrated that the modelled receptor pocket conformations can be validated or improved via docking of known ligands. For the Neurokinin 2 receptor, ligand 6-methylbenzo[b]thiophene-2-carboxylic acid (1-\{(S)-1-benzyl-4-[4-(tetrahydropyran-4-ylmethyl)piperazin-1-yl]butylcarbamoyl\}cyclopentyl)amide (abbreviated as 10i in the original article) was used as the well-known antagonist with high affinity (Fattori et al., 2010). As for the 5-HT6 receptor, AVN-492, a new promising ligand (now tested in phase I trials) was selected (Ivachtchenko et al., 2017; Łażewska et al., 2019).

Eventually, all eight Schiff bases were docked into these 18 possible targets with the program $S Y B Y L-X$ (Tripos, 2012) by calculating the Total Score of Surflex-dock (Table 3) (Rarey et al., 1996). The docking results were then compared with MTT results to gain insight into the most possible molecular targets. Spearman's rank correlation coefficient $\rho$ (Fieller et al., 1957) was introduced to assess the strength of each target's monotonic relationship (Table 3). The closer $\rho$ is to 1 , the stronger the monotonic relationship. As we can see, $\rho$ values of three targets [i.e. human ether-á-go-go-related (hERG) potassium channel, inhibitor of apoptosis protein 3 and serine/threonine- 
Table 3

Total scores and Spearman's rank correlation coefficients ( $\rho$ in the last two rows) of 18 possible targets (PDB IDs are in brackets; two targets in the last two columns were docked using homology modules for the absence of detailed 3D information).

$$
\begin{aligned}
\rho_{\mathrm{A} 549} & =1-\frac{6 \Sigma\left(\operatorname{Rank}_{i}-\operatorname{Rank}_{\mathrm{A} 549}\right)^{2}}{n\left(n^{2}-1\right)} \\
\rho_{4 \mathrm{~T}_{1}} & =1-\frac{6 \Sigma\left(\operatorname{Rank}_{i}-\operatorname{Rank}_{4 \mathrm{~T}_{1}}\right)^{2}}{n\left(n^{2}-1\right)}
\end{aligned}
$$

\begin{tabular}{|c|c|c|c|c|c|c|c|c|c|}
\hline & $\begin{array}{l}\text { c-Jun } \\
\text { N-terminal } \\
\text { kinase } 3 \\
(2 \mathrm{r} 9 \mathrm{~s}) \\
\end{array}$ & $\begin{array}{l}\text { CaM } \\
\text { kinase II } \\
(2 \mathrm{vz} 6) \\
\end{array}$ & $\begin{array}{l}\text { Delta } \\
\text { opioid } \\
\text { receptor } \\
(4 \mathrm{n} 6 \mathrm{~h})\end{array}$ & $\begin{array}{l}\text { Gonadotropin- } \\
\text { releasing } \\
\text { hormone } \\
\text { receptor } \\
(6 \mathrm{nbf})\end{array}$ & $\begin{array}{l}\text { hERG } \\
\text { (3o0u) }\end{array}$ & $\begin{array}{l}\text { Inhibitor of } \\
\text { apoptosis } \\
\text { protein } 3 \\
(5 \mathrm{c} 3 \mathrm{~h}) \\
\end{array}$ & $\begin{array}{l}\text { Kinesin-like } \\
\text { protein } 1 \\
\text { (3zcw) }\end{array}$ & $\begin{array}{l}\text { Mu opioid } \\
\text { receptor } \\
\text { (4dkl) }\end{array}$ & $\begin{array}{l}\text { Probable } \\
\text { G-protein } \\
\text { coupled } \\
\text { receptor } \\
88(5 \times 1)\end{array}$ \\
\hline Ligand $^{i}$ & 12.24 & 9.27 & 9.37 & 7.76 & 9.87 & 7.33 & 19.68 & 10.53 & 6.67 \\
\hline BDHFI & 8.08 & 8.43 & 7.56 & 6.19 & 6.90 & 6.23 & 10.44 & 8.57 & 6.85 \\
\hline BDHAI & 8.16 & 8.82 & 7.44 & 6.36 & 8.02 & 6.14 & 6.99 & 9.46 & 6.15 \\
\hline BDHMFI & 5.96 & 6.92 & 6.53 & 6.77 & 4.54 & 5.07 & 8.61 & 8.23 & 5.28 \\
\hline BMHAI & 5.60 & 6.80 & 6.32 & 5.88 & 6.41 & 4.77 & 8.27 & 6.15 & 4.52 \\
\hline BMHMFI & 6.39 & 5.98 & 6.65 & 4.19 & 4.91 & 4.42 & 7.76 & 6.36 & 4.58 \\
\hline BMHFN & 5.59 & 6.03 & 6.45 & 4.67 & 4.20 & 4.30 & 6.16 & 6.47 & 4.37 \\
\hline$\rho \mathrm{A} 549^{\mathrm{ii}}$ & 0.67 & 0.74 & 0.57 & 0.71 & 0.86 & 0.83 & 0.48 & 0.52 & 0.62 \\
\hline$\rho 4 \mathrm{~T}_{1}^{\mathrm{iii}}$ & 0.69 & 0.76 & 0.55 & 0.74 & 0.88 & 0.81 & 0.33 & 0.55 & 0.60 \\
\hline Ligand $^{i}$ & 7.34 & 16.79 & 32.82 & 15.18 & 10.64 & 10.81 & 23.41 & 10.04 & 9.00 \\
\hline BDHFI & 6.35 & 8.22 & 9.73 & 6.70 & 8.00 & 8.34 & 7.39 & 9.28 & 7.95 \\
\hline BDHAI & 6.79 & 6.40 & 9.60 & 8.19 & 9.92 & 7.17 & 8.12 & 8.80 & 4.56 \\
\hline BDHMFI & 5.27 & 5.65 & 6.64 & 5.56 & 4.45 & 1.87 & 6.02 & 8.17 & 6.40 \\
\hline BDHFN & 5.47 & 5.51 & 7.59 & 5.63 & 5.51 & 5.23 & 7.99 & 8.73 & 7.07 \\
\hline BMHFI & 4.43 & 7.06 & 7.95 & 7.87 & 6.39 & 6.41 & 5.44 & 6.71 & 5.05 \\
\hline BMHAI & 4.87 & 6.67 & 7.01 & 7.68 & 7.49 & 8.27 & 5.51 & 5.68 & 5.50 \\
\hline BMHMFI & 5.06 & 6.77 & 5.52 & 5.92 & 6.42 & 7.00 & 5.05 & 6.00 & 4.43 \\
\hline BMHFN & 4.30 & 7.46 & 5.80 & 5.92 & 6.06 & 6.23 & 5.22 & 6.44 & 6.18 \\
\hline$\rho \mathrm{A} 549^{\mathrm{ii}}$ & 0.60 & 0.12 & 0.86 & 0.62 & 0.69 & 0.69 & 0.62 & 0.52 & 0.17 \\
\hline$\rho 4 \mathrm{~T}_{1}^{\mathrm{iii}}$ & 0.62 & 0.00 & 0.83 & 0.69 & 0.71 & 0.64 & 0.67 & 0.50 & 0.02 \\
\hline
\end{tabular}

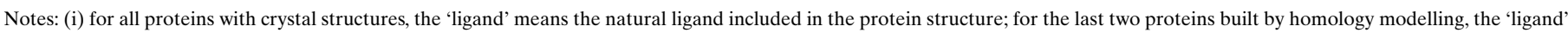

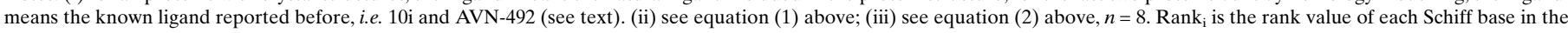

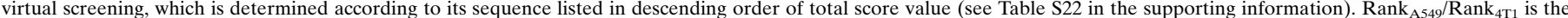

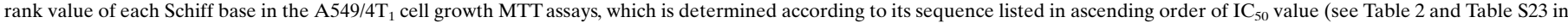
the supporting information).

protein kinase PIM1] are above 0.80 , their correlations can be described as 'very strong' (bold in Table 3). Thus, they can be regarded as the most possible targets.

\subsection{Comparison of binding modes between active and less} active ligands

Among the three most possible targets, hERG (PDB ID 3o0u) has the highest Spearman's rank correlation coefficient values and is ranked as the best, so the comparison of binding modes is performed based on the docking results of eight Schiff bases with hERG, in order to gain insight into the nature of the structure-activity relationships.

According to our docking simulation, shown in Fig. 9, the active and less active ligands have different binding modes. In both BDHFI and BDHAI, two hydrogen bonds were formed, one is between the indole $\mathrm{N}-\mathrm{H}$ group and GLN19/GLU59, and the other is between an imine $\mathrm{N}$ atom and $\mathrm{HOH} 267 /$ GLY66. But in both BDHMFI and BDHFN, no hydrogen bond was formed and aromatic hydrophobic interactions dominate the affinity between the protein and the ligand. This phenomenon can be confirmed by the Polar values, which are 2.60 and 2.18 for BDHFI and BDHAI, respectively, but zero for BDHMFI and BDHFN.

As for the BMH series of four mono-Schiff bases, all of them exhibit one to five hydrogen bonds within the active site (Fig. 10). Indole $\mathrm{N}-\mathrm{H}$ groups and imine $\mathrm{N}$ atoms form one or two hydrogen bonds in both BMHFI and BMHAI. A carboxyl $\mathrm{O}$ atom forms an extra hydrogen bond in BMHAI, which is 

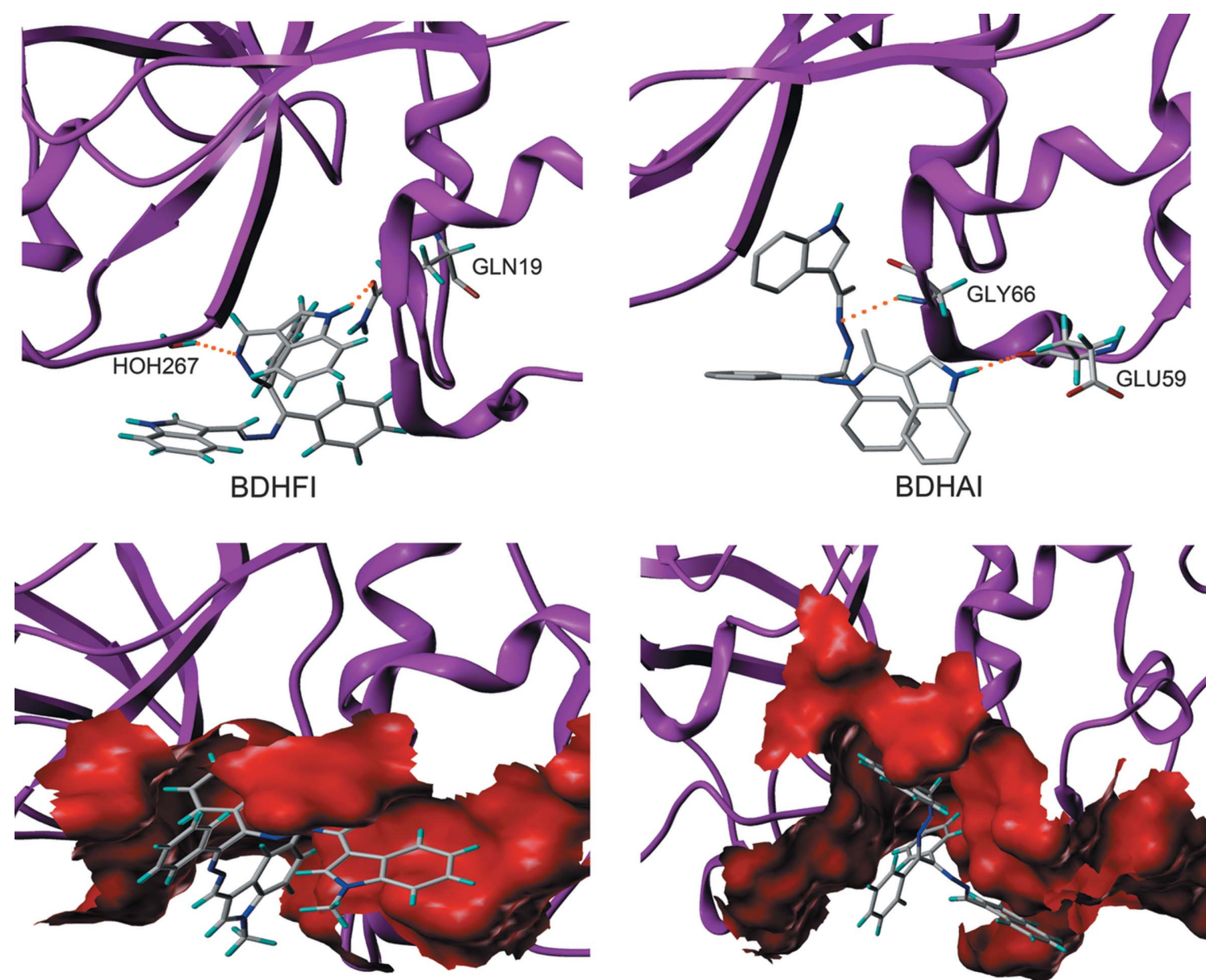

BDHMFI

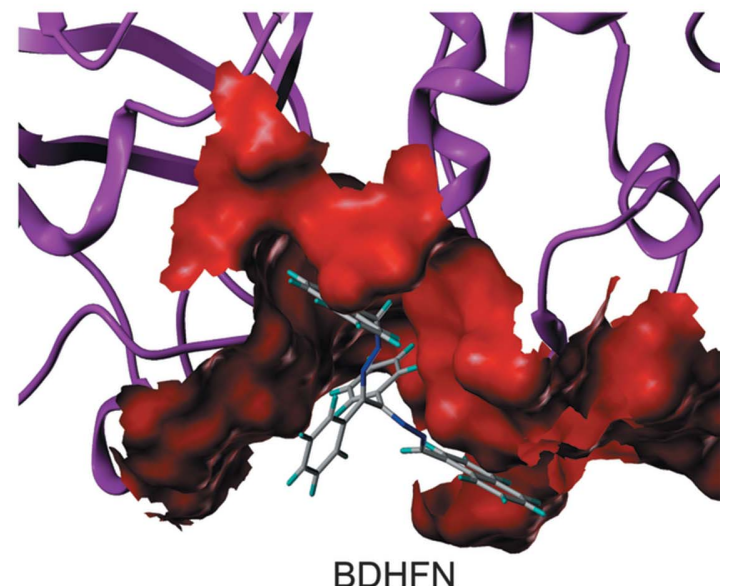

\begin{tabular}{lrllrlrlr}
\hline & Total_Score & \multicolumn{1}{l}{ Crash } & \multicolumn{1}{l}{ Polar } & Similarity & \multicolumn{1}{l}{ D_score } & PMF_score & \multicolumn{1}{l}{ G_score } & \multicolumn{1}{c}{ ChemScore } \\
\hline BDHFI & 6.8994 & -2.3222 & 2.5972 & 0.248 & -130.2239 & -5.6982 & -207.9752 & -27.1866 \\
BDHAI & 8.0205 & -1.8365 & 2.1828 & 0.369 & -184.6051 & -6.2585 & -278.7422 & -36.6271 \\
BDHMFI & 4.5397 & -2.5519 & 0.0001 & 0.402 & -200.1143 & -1.778 & -296.3246 & -35.8267 \\
BDHFN & 6.2457 & -1.0928 & 0 & 0.407 & -150.1006 & 68.1354 & -225.1856 & -32.8227 \\
\hline
\end{tabular}

Figure 9

The calculated binding modes of BDHFI, BDHAI, BDHMFI and BDHFN with hERG (PDB ID: 3o0u). Hydrogen bonds are shown with orange dotted lines. If no hydrogen bond is formed, surfaces that contain the active sites are displayed (red surface). Total score values and seven additional contributing parts or scores are listed underneath for comparison.

the reason why it has a higher Total Score (also Polar value) than BMHFI. BMHMFI and BMHFN can form only one hydrogen bond with protein through a carboxyl $\mathrm{O}$ or imine $\mathrm{N}$ atom, so their docking Total Scores (also Polar values) are lower than those of BMHFI and BMHAI. Put simply, the more hydrogen bonds formed, the higher the Total Score values in the docking simulations, and the better the antiproliferative activities of the ligands.

There is one phenomenon that seems confusing, i.e. BDHFN has a higher Total Score than BMHFI (6.25 versus 5.97), but the former has a lower cytotoxic activity than the latter. Apparently, the deviation between docking predictions and experimental activities may partly explain this result.
Here, we consider another class of scoring function based on a potential of mean force, so-called PMF-based scores, which is a knowledge-based scoring approach based on the work of Muegge and Martin (Muegge \& Martin, 1999; Muegge, 2006). The PMF-based scoring functions are statistical, because it is calculated as the sum of the overall atom-pair interaction Helmholtz free energies between the protein and ligand, neglecting other characteristics of the environment and mutual orientation of the atom (Lizunov et al., 2015). As we know, the higher the PMF value, the poorer the protein-ligand binding affinity (Sharma \& Ghoshal, 2006). From the seventh columns in Figs. 9 and 10, we can see that BDHFN has the highest PMF score (68.14) and is ranked as the worst with 

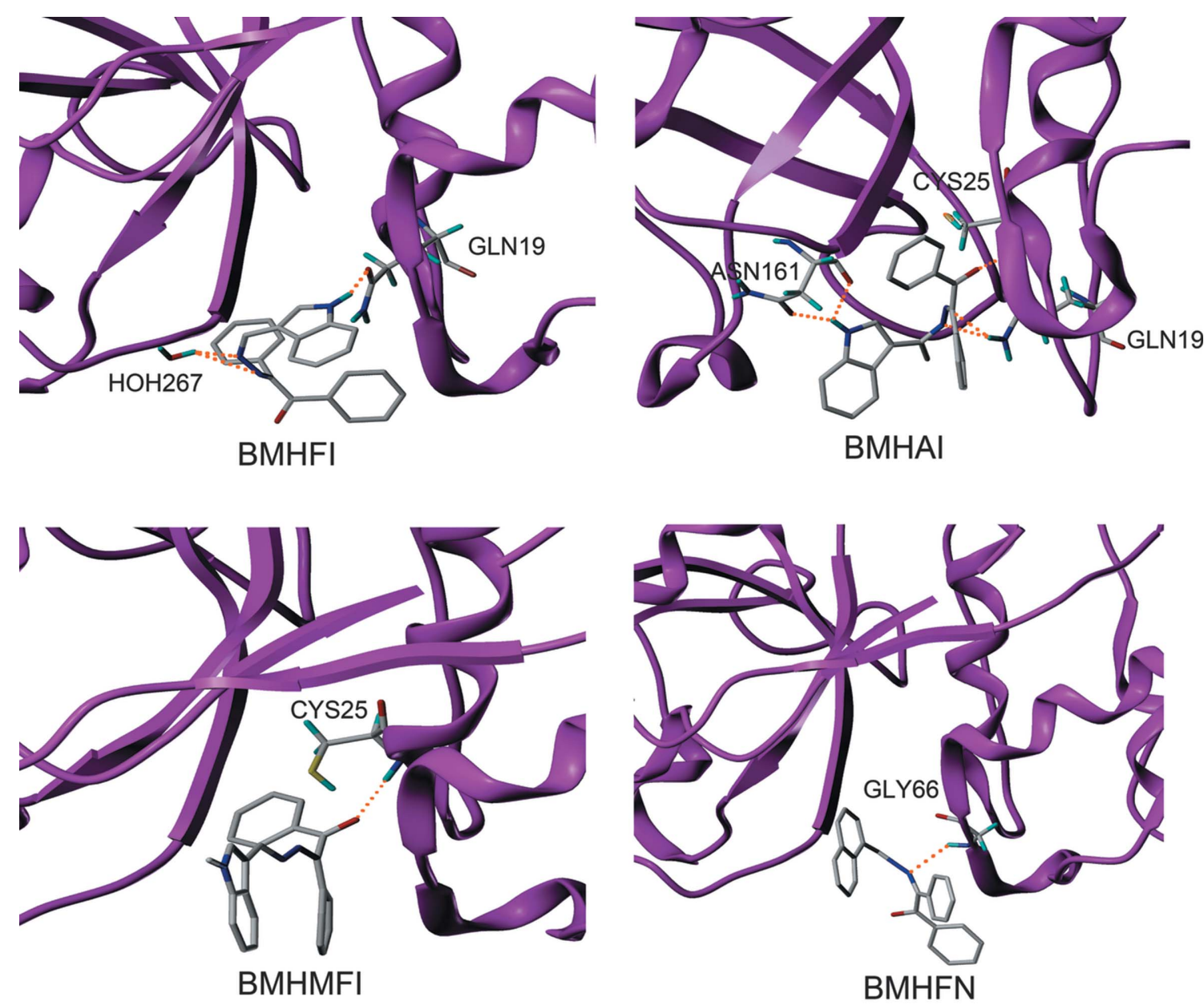

\begin{tabular}{lrllrlrrr}
\hline & Total_Score & \multicolumn{1}{l}{ Crash } & \multicolumn{1}{l}{ Polar } & Similarity & \multicolumn{1}{l}{ D_score } & PMF_score & \multicolumn{1}{l}{ G_score } & \multicolumn{1}{c}{ ChemScore } \\
\hline BMHFI & 5.9744 & -2.0025 & 2.5268 & 0.222 & -108.1605 & -12.0139 & -166.6515 & -26.6604 \\
BMHAI & 6.408 & -1.027 & 4.2604 & 0.329 & -110.4748 & 6.0784 & -166.7928 & -31.1578 \\
BMHMFI & 4.9056 & -1.5938 & 1.0908 & 0.438 & -143.612 & 10.3378 & -217.7523 & -30.984 \\
BMHFN & 4.2017 & -1.0311 & 0.1059 & 0.361 & -111.2041 & 28.928 & -189.9784 & -27.0685 \\
\hline
\end{tabular}

Figure 10

The calculated binding modes of BMHFI, BMHAI, BMHMFI and BMHFN with hERG (PDB ID: 3o0u). Hydrogen bonds are shown with orange dotted lines. Total score values and seven additional contributing parts or scores are listed underneath for comparison.

respect to the means of the distance-dependent Helmholtz free energies. That is to say, a long distance between the protein and ligand has a detrimental contribution to the affinity, which has not been reflected apparently in the Total Score. On the other hand, this phenomenon confirms the conclusion that PMF has essential differences with all of the other scoring functions. Its unique knowledge-based algorithm parameterized using crystal complexes is distinctive (Liu et al., 2012).

The above explanation is also suitable to BMHAI versus BDHFI/BDHAI. The former exhibit five hydrogen bonds within the active site, but it has a lower Total Score and weaker cytotoxic activity than the latter two. The PMF score of BMHAI is 6.08, revealing poorer binding affinities compared with the meager binding scores of BDHFI and BDHAI $(-5.70$ and -6.26 , respectively).
In brief, all of the docking results were in good agreement with the experimental results, indicating the most probable target and reasonable structure-activity relationships.

\section{Conclusion}

Schiff bases have been used widely in the pharmaceutical industry because of their antimicrobial, anti-inflammatory and anticancer properties. We have described the synthesis and structural characterization of eight novel Schiff bases derived from BDH/BMH. These synthesized Schiff base compounds have similar molecular structures despite having different terminal fused two-ring aromatics and different substituents. MTT assays proved that the BDH series of compounds show higher inhibitory activity compared with the BMH series. The biological screening results favour the activities of indole- 
containing Schiff bases instead of naphthalene-containing ones. The cytotoxic activity is also affected by the nature of the substituents at the indole $\mathrm{N}$ atom; the replacement of hydrogen by methyl will decrease the cytotoxic activities greatly, while the same replacement on the imine $\mathrm{C}-\mathrm{H}$ group has little effect. Generally, our in vitro findings show that four of these compounds have high antiproliferative activity against human lung cancer cell line A549 and mouse breast cancer cell line $4 \mathrm{~T}_{1}$; two show obvious and comparable activities with cisplatin. All compounds exhibited weaker cytotoxicity against normal cells than cancer cells.

Swiss Target Prediction online servers were used to screen compounds against large numbers of molecular targets. After careful examination, 18 possible targets were generated for further screening through the reverse docking approach. Afterwards, the three most possible targets were chosen on account of their correlation with experimental data. Bearing the highest consistency, the docking results of hERG (PDB ID: 3o0u) with eight Schiff bases can easily explain the structure-activity relationships obtained experimentally.

In conclusion, the present work indicates that introduction of an indole ring on the terminal of this kind of X-shaped Schiff base leads to the generation of potent anticancer agents.

\section{Funding information}

Funding for this research was provided by: Key Laboratory of Pulp and Paper Science and Technology of Ministry of Education/Shandong Province of China (award Nos. KF201712 and KF201821); State Key Laboratory of Biobased Material and Green Papermaking, Qilu University of Technology, Shandong Academy of Sciences (grant No. ZZ20190115).

\section{References}

Akula, M., Yogeeswari, P., Sriram, D., Jha, M. \& Bhattacharya, A. (2016). RSC Adv. 6, 46073-46080.

Ali Khan, M. S., Misbah Ahmed, N., Arifuddin, M., Rehman, A. \& Ling, M. P. (2018). Food Chem. Toxicol. 118, 953-962.

Anush, S. M., Vishalakshi, B., Kalluraya, B. \& Manju, N. (2018). Int. J. Biol. Macromol. 119, 446-452.

Ariyaeifar, M., Amiri Rudbari, H., Sahihi, M., Kazemi, Z., Kajani, A. A., Zali-Boeini, H., Kordestani, N., Bruno, G. \& Gharaghani, S. (2018). J. Mol. Struct. 1161, 497-511.

Atienza, B. J. P., Jensen, L. D., Noton, S. L., Ansalem, A. K. V., Hobman, T., Fearns, R., Marchant, D. J. \& West, F. G. (2018). J. Org. Chem. 83, 6829-6842.

Bach, R. D., Woodard, R. A., Anderson, T. J. \& Glick, M. D. (1982). J. Org. Chem. 47, 3707-3712.

Bai, J., Zhang, P., Bao, G., Gu, J.-G., Han, L., Zhang, L.-W. \& Xu, Y. (2018). Appl. Microbiol. Biotechnol. 102, 8493-8500.

Bai, Y., Gao, H., Qi, Z. Y. \& Dang, D. B. (2012). Synth. React. Inorg. Met.-Org. Nano-Met. Chem. 42, 53-58.

Bano, B., Khan, K. M., Jabeen, A., Hameed, A., Faheem, A., Taha, M., Perveen, S. \& Iqbal, S. (2017). ChemistrySelect, 2, 10050-10054.

Bao, B., Zhang, P., Lee, Y., Hong, J., Lee, C. O. \& Jung, J. H. (2007). Mar. Drugs 5, 31-39.

Becke, A. D. (1993). J. Chem. Phys. 98, 5648-5652.

Bertamino, A., Iraci, N., Ostacolo, C., Ambrosino, P., Musella, S., Di Sarno, V., Ciaglia, T., Pepe, G., Sala, M., Soldovieri, M. V., Mosca, I., Gonzalez-Rodriguez, S., Fernandez-Carvajal, A., Ferrer-Montiel,
A., Novellino, E., Taglialatela, M., Campiglia, P. \& GomezMonterrey, I. (2018). J. Med. Chem. 61, 6140-6152.

Bharathi Dileepan, A. G., Daniel Prakash, T., Ganesh Kumar, A., Shameela Rajam, P., Violet Dhayabaran, V. \& Rajaram, R. (2018). J. Photochem. Photobiol. B, 183, 191-200.

Bienert, S., Waterhouse, A., de Beer, T. A. P., Tauriello, G., Studer, G., Bordoli, L. \& Schwede, T. (2017). Nucleic Acids Res. 45, D313D319.

Blunt, J. W., Copp, B. R., Munro, M. H., Northcote, P. T. \& Prinsep, M. R. (2011). Nat. Prod. Rep. 28, 196-268.

Boys, S. B. \& Bernardi, F. (1970). Mol. Phys. 19, 553-566.

Brandenburg, K. \& Putz, H. (1999). DIAMOND. Crystal Impact GbR, Bonn, Germany.

Brigg, S., Pribut, N., Basson, A. E., Avgenikos, M., Venter, R., Blackie, A., van Otterlo, W. A. L. \& Pelly, S. C. (2016). Bioorg. Med. Chem. Lett. 26, 1580-1584.

Bruker (2000). SMART, SAINT, SADABS, XPREP and SHELXTL. Bruker AXS Inc., Madison, Wisconsin, USA.

Bu, F.-Z., Tan, X.-J., Xing, D.-X. \& Wang, C. (2017). Acta Cryst. C73, 546-555.

Carreño, A., Zúñiga, C., Páez-Hernández, D., Gacitúa, M., Polanco, R., Otero, C., Arratia-Pérez, R. \& Fuentes, J. A. (2018). New J. Chem. 42, 8851-8863.

Chandra, S., Verma, S. \& Gautam, A. (2007). J. Saudi Chem. Soc. 11, 483-488.

Chandrashekaran, I. R., Rao, G. S. \& Cowsik, S. M. (2009). J. Chem. Inf. Model. 49, 1734-1740.

Chauhan, S., Swami, M., Malik, S. \& Singh, R. V. (2008). Main Group Met. Chem. 31, 263-272.

Cheng, S.-S., Shi, Y., Ma, X.-N., Xing, D.-X., Liu, L.-D., Liu, Y., Zhao, Y.-X., Sui, Q.-C. \& Tan, X.-J. (2016). J. Mol. Struct. 1115, 228240.

Cihan-Üstündağ, G., Gürsoy, E., Naesens, L., Ulusoy-Güzeldemirci, N. \& Çapan, G. (2016). Bioorg. Med. Chem. 24, 240-246.

Dai, W., Jiang, X. L., Tao, J. Y. \& Shi, F. (2016). J. Org. Chem. 81, 185192.

Daina, A., Michielin, O. \& Zoete, V. (2019). Nucleic Acids Res. 47, W357-W364.

De, S., Chowdhury, S., Tocher, D. A. \& Datta, D. (2006). CrystEngComm, 8, 670-673.

Drew, M. G. B., Parui, D., De, S., Chowdhury, S. \& Datta, D. (2007). New J. Chem. 31, 1763-1768.

El-Sawy, E. R., Bassyouni, F. A., Abu-Bakr, S. H., Rady, H. M. \& Abdlla, M. M. (2010). Acta Pharm. 60, 55-71.

El-Sawy, E. R., Mandour, A. H., El-Hallouty, S. M., Shaker, K. H. \& Abo-Salem, H. M. (2013). Arabian J. Chem. 6, 67-78.

El-Sawy, E. R., Mandour, A. H., Mahmoud, K., Islam, I. E. \& AboSalem, H. M. (2012). Acta Pharm. 62, 157-179.

Ensch, M., Maldonado, V. Y., Swain, G. M., Rechenberg, R., Becker, M. F., Schuelke, T. \& Rusinek, C. A. (2018). Anal. Chem. 90, 19511958.

Erxleben, A. (2018). Inorg. Chim. Acta, 472, 40-57.

Estevão, M. S., Carvalho, L. C., Ribeiro, D., Couto, D., Freitas, M., Gomes, A., Ferreira, L. M., Fernandes, E. \& Marques, M. M. B. (2010). Eur. J. Med. Chem. 45, 4869-4878.

Evans, B. E., Rittle, K. E., Bock, M. G., DiPardo, R. M., Freidinger, R. M., Whitter, W. L., Lundell, G. F., Veber, D. F., Anderson, P. S., Chang, R. S., Lotti, V. J., Cerino, D. J., Chen, T. B., Kling, P. J., Kunkel, K. A., Springer, J. P. \& Hirshfield, J. (1988). J. Med. Chem. 31, 2235-2246.

Fantinati, A., Bianco, S., Guerrini, R., Salvadori, S., Pacifico, S., Cerlesi, M. C., Calo, G. \& Trapella, C. (2017). Sci. Rep. UK, 7, 1-7.

Farag, A. K., Elkamhawy, A., Londhe, A. M., Lee, K.-T., Pae, A. N. \& Roh, E. J. (2017). Eur. J. Med. Chem. 141, 657-675.

Farrugia, L. J. (2012). J. Appl. Cryst. 45, 849-854.

Fattori, D., Porcelloni, M., D'Andrea, P., Catalioto, R.-M., Ettorre, A., Giuliani, S., Marastoni, E., Mauro, S., Meini, S., Rossi, C., Altamura, M. \& Maggi, C. A. (2010). J. Med. Chem. 53, 4148-4165. 
Fieller, E. C., Hartley, H. O. \& Pearson, E. S. (1957). Biometrika, 44, 470-481.

Fisher, H. M. \& Stoufer, R. C. (1966). Inorg. Chem. 5, 1172-1177.

Fortes, M. P., da Silva, P. N. B., da Silva, T. G., Kaufman, T. S., Militão, G. C. G. \& Silveira, C. C. (2016). Eur. J. Med. Chem. 118, 21-26.

Frisch, M. J., Pople, J. A. \& Binkley, J. S. (1984). J. Chem. Phys. 80, 3265-3269.

Frisch, M. J., et al. (2004). GAUSSIAN03. Revision C.02. Gaussian Inc., Wallingford, CT, USA. http://www.gaussian.com.

Ganguly, A., Chakraborty, P., Banerjee, K. \& Choudhuri, S. K. (2014). Eur. J. Pharm. Sci. 51, 96-109.

George, S., Parameswaran, M. K., Chakraborty, A. \& Ravi, T. K. (2008). Acta Pharm. 58, 119-129.

Gfeller, D., Michielin, O. \& Zoete, V. (2013). Bioinformatics, 29, 3073-3079.

Gul, W. \& Hamann, M. T. (2005). Life Sci. 78, 442-453.

Gurer-Orhan, H., Karaaslan, C., Ozcan, S., Firuzi, O., Tavakkoli, M., Saso, L. \& Suzen, S. (2016). Bioorg. Med. Chem. 24, 1658-1664.

Hassam, M., Basson, A. E., Liotta, D. C., Morris, L., van Otterlo, W. A. L. \& Pelly, S. C. (2012). ACS Med. Chem. Lett. 3, 470-475. Hirshfeld, F. L. (1977). Theor. Chim. Acta, 44, 129-138.

Hong, W. D., Gibbons, P. D., Leung, S. C., Amewu, R., Stocks, P. A., Stachulski, A., Horta, P., Cristiano, M. L. S., Shone, A. E., Moss, D., Ardrey, A., Sharma, R., Warman, A. J., Bedingfield, P. T. P., Fisher, N. E., Aljayyoussi, G., Mead, S., Caws, M., Berry, N. G., Ward, S. A., Biagini, G. A., O’Neill, P. M. \& Nixon, G. L. (2017). J. Med. Chem. 60, 3703-3726.

Ivachtchenko, A. V., Okun, I., Aladinskiy, V., Ivanenkov, Y., Koryakova, A., Karapetyan, R., Mitkin, O., Salimov, R. \& Ivashchenko, A. (2017). J. Alzheimers Dis. 58, 1043-1063.

Johansson, H., Jørgensen, B. T., Gloriam, E. D., Bräuner-Osborne, H. \& Pedersen, S. D. (2013). RSC Adv. 3, 945-960.

Kalaiarasi, G., Rex Jeya Rajkumar, S., Aswini, G., Dharani, S., Fronczek, F. R. \& Prabhakaran, R. (2018). Spectrochim. Acta A Mol. Biomol. Spectrosc. 200, 246-262.

Kamath, P. R., Sunil, D., Ajees, A. A., Pai, K. S. R. \& Biswas, S. (2016). Eur. J. Med. Chem. 120, 134-147.

Ke, S., Wei, Y., Shi, L., Yang, Q. \& Yang, Z. (2013). Anticancer Agents Med. Chem. 13, 1291-1298.

Khayyat, S., Amr, A. E. E., Salam, O. I. A. E., Al-Omar, M. A. \& Abdalla, M. M. (2015). Int. J. Pharmacol. 11, 423-431.

Kim, S. \& Yoon, J.-Y. (2004). Sci. Synth. 27, 671-722.

Krishnan, R., Binkley, J. S., Seeger, R. \& Pople, J. A. (1980). J. Chem. Phys. 72, 650-654.

Kumar, D., Kumar, M. N., Akamatsu, K., Kusaka, E., Harada, H. \& Ito, T. (2016). Bioorg. Med. Chem. Let. 20, 3916-3919.

Lamie, P. F., Ali, W. A. M., Bazgier, V. \& Rárová, L. (2016). Eur. J. Med. Chem. 123, 803-813.

Łażewska, D., Kurczab, R., Więcek, M., Kamińska, K., Satała, G., Jastrzębska-Więsek, M., Partyka, A., Bojarski, A. J., Wesołowska, A., Kieć-Kononowicz, K. \& Handzlik, J. (2017). Eur. J. Med. Chem. 135, 117-124.

Łażewska, D., Kurczab, R., Więcek, M., Satała, G., Kieć-Kononowicz, K. \& Handzlik, J. (2019). Bioorg. Chem. 84, 319-325.

Lee, C., Yang, W. \& Parr, R. G. (1988). Phys. Rev. B, 37, 785-789.

Liu, S., Fu, R., Zhou, L.-H. \& Chen, S.-P. (2012). PLoS One, 7, e38086.

Lizunov, A. Y., Gonchar, A. L., Zaitseva, N. I. \& Zosimov, V. V. (2015). J. Chem. Inf. Model. 55, 2121-2137.

Ma, J.-Y., Quan, Y.-C., Jin, H.-G., Zhen, X.-H., Zhang, X.-W. \& Guan, L.-P. (2016). Chem. Biol. Drug Des. 87, 342-351.

Malik, M. A., Dar, O. A., Gull, P., Wani, M. Y. \& Hashmi, A. A. (2018). MedChemComm, 9, 409-436.

Mandour, A. H., El-Sawy, E. R., Shaker, K. H. \& Mustafa, M. A. (2010). Acta Pharm. 60, 73-88.

Mayans, J., Font-Bardia, M., Di Bari, L., Arrico, L., Zinna, F., Pescitelli, G. \& Escuer, A. (2018). Chem. Eur. J. 24, 7653-7663.

McLean, A. D. \& Chandler, G. S. (1980). J. Chem. Phys. 72, 56395648.
Mishra, S., Kaur, M., Chander, S., Murugesan, S., Nim, L., Arora, D. S. \& Singh, P. (2018). Eur. J. Med. Chem. 155, 658-669.

Møller, C. \& Plesset, M. S. (1934). Phys. Rev. 46, 618-622.

Mor, M., Silva, C., Vacondio, F., Plazzi, P. V., Bertoni, S., Spadoni, G., Diamantini, G., Bedini, A., Tarzia, G., Zusso, M., Franceschini, D. \& Giusti, P. (2004). J. Pineal Res. 36, 95-102.

Muegge, I. (2006). J. Med. Chem. 49, 5895-5902.

Muegge, I. \& Martin, Y. C. (1999). J. Med. Chem. 42, 791-804.

Mukherjee, A., Dutta, A., JANA, A. D. \& Patra, G. K. (2013). Inorg. Chim. Acta, 404, 131-143.

Naidu, K. M., Srinivasarao, S., Agnieszka, N., Ewa, A. K., Kumar, M. M. K. \& Chandra Sekhar, K. V. G. (2016). Bioorg. Med. Chem. Lett. 26, 2245-2250.

Naim, M. J., Alam, O., Alam, Md. J., Bano, F., Alam, P. \& Shrivastava, N. (2016). Int. J. Pharm. Sci. Res. 7, 51-62.

Ndagijimana, A., Wang, X., Pan, G., Zhang, F., Feng, H. \& Olaleye, O. (2013). Fitoterapia, 86, 35-47.

Pedada, R. S., Yarla, S. N., Tambade, J. P., Dhananjaya, L. B., Bishayee, A., Arunasree, M. K., Philip, H. G., Dharmapuri, G., Aliev, G., Putta, S. \& Rangaiah, G. (2016). Eur. J. Med. Chem. 112, 289-297.

Pojarová, M., Kaufmann, D., Gastpar, R., Nishino, T., Reszka, P., Bednarski, P. J. \& von Angerer, E. (2007). Bioorg. Med. Chem. 15, 7368-7379.

Pramanik, K., Malpaharia, P., Colacio, E., Das, B. \& Chandra, S. K. (2018). New J. Chem. 42, 6332-6342.

Pu, C., Luo, R.-H., Zhang, M., Hou, X., Yan, G., Luo, J., Zheng, Y.-T. \& Li, R. (2017). Bioorg. Med. Chem. Lett. 27, 4150-4155.

Rarey, M., Kramer, B., Lengauer, T. \& Klebe, G. (1996). J. Mol. Biol. 261, 470-489.

Rassolov, V. A., Ratner, M. A., Pople, J. A., Redfern, P. C. \& Curtiss, L. A. (2001). J. Comput. Chem. 22, 976-984.

Sá Alves, F. R. de, Barreiro, E. J. \& Fraga, C. A. (2009). Mini Rev. Med. Chem. 9, 782-793.

Saini, T., Kumar, S. \& Narasimhan, B. (2016). Cent. Nerv. Syst. Agents Med. Chem. 16, 19-28.

Salavati-Niasari, M. \& Hassani-Kabutarkhani, M. (2005). Synth. React. Inorg. Met.-Org. Nano-Met. Chem. 35, 469-475.

Santhosh Kumar, G., Poornachandra, Y., Kumar Gunda, S., Ratnakar Reddy, K., Mohmed, J., Shaik, K., Ganesh Kumar, C. \& Narsaiah, B. (2018). Bioorg. Med. Chem. Lett. 28, 2328-2337.

Sellitto, G., Faruolo, A., de Caprariis, P., Altamura, S., Paonessa, G. \& Ciliberto, G. (2010). Bioorg. Med. Chem. 18, 6143-6148.

Shaaban, M. \& Abdel-Aziz, M. S. (2007). Nat. Prod. Res. 21, $1205-$ 1211.

Shaaban, M., Maskey, R. P., Wagner-Döbler, I. \& Laatsch, H. (2002). J. Nat. Prod. 65, 1660-1663.

Sharma, P. \& Ghoshal, N. (2006). J. Chem. Inf. Model. 46, 1763-1774.

Sheldrick, G. M. (2015a). Acta Cryst. A71, 3-8.

Sheldrick, G. M. (2015b). Acta Cryst. C71, 3-8.

Singh, G., Kalra, P., Arora, A., Singh, A., Sharma, G., Sanchita, Maurya, I. K., Dutta, S., Munshi, P. \& Verma, V. (2018). ChemistrySelect, 3, 2366-2375.

Singh, R. V., Fahmi, N., Swami, M. \& Chauhan, S. (2008). J Macromol. Sci. A, 45, 159-163.

Spek, A. L. (2009). Acta Cryst. D65, 148-155.

Sugiyama, Y., Ito, Y., Suzuki, M. \& Hirota, A. (2009). J. Nat. Prod. 72 , 2069-2071.

Suzen, S. \& Buyukbingol, E. (2000). Farmaco, 55, 246-248.

Tan, X.-J., Hao, X.-Q., Zhao, Q.-Z., Cheng, S.-S., Xie, W.-L., Xing, D.-X., Liu, Y. \& Song, L.-Z. (2015). J. Mol. Struct. 1099, 373387.

Tan, X.-J., Zhang, L.-Y., Sun, Y.-K. \& Zhou, X.-M. (2019). Acta Cryst. C75, 97-106.

Tripos (2012). SYBYL-X. Version 2.0. Tripos International, St Louis, MO, USA. http://www.tripos.com.

Turner, M. J., McKinnon, J. J., Wolff, S. K., Grimwood, D. J., Spackman, P. R., Jayatilaka, D. \& Spackman, M. A. (2017). 
CrystalExplorer17. University of Western Australia. http://crystalexplorer.scb.uwa.edu.au/.

Tzvetkov, N. T., Hinz, S., Küppers, P., Gastreich, M. \& Müller, C. E. (2014). J. Med. Chem. 57, 6679-6703.

Unver, Y. \& Bektas, E. (2018). Lett. Drug. Des. \& Discov. 15, 706712.

Vardhan, H., Mehta, A., Nath, I. \& Verpoort, F. (2015). RSC Adv. 5, 67011-67030.

Venkatesan, V., Kumar, S. K. A., Bothra, S. \& Sahoo, S. K. (2018). New J. Chem. 42, 6175-6182.

Wang, Q., Qu, Y., Xia, Q., Song, H.-J., Song, H.-B., Liu, Y. \& Wang, Q. (2018). Chem. Eur. J. 24, 11283-11287.

Waterhouse, A., Bertoni, M., Bienert, S., Studer, G., Tauriello, G., Gumienny, R., Heer, F. T., de Beer, T. A. P., Rempfer, C., Bordoli,
L., Lepore, R. \& Schwede, T. (2018). Nucleic Acids Res. 46, W296W303.

Wu, Y. S., Coumar, M. S., Chang, J. Y., Sun, H. Y., Kuo, F. M., Kuo, C. C., Chen, Y. J., Chang, C. Y., Hsiao, C. L., Liou, J. P., Chen, C. P., Yao, H. T., Chiang, Y. K., Tan, U. K., Chen, C. T., Chu, C. Y., Wu, S. Y., Yeh, T. K., Lin, C. Y. \& Hsieh, H. P. (2009). J. Med. Chem. 52, 4941-4945.

Yu, H.-F., Qin, X.-J., Ding, C.-F., Wei, X., Yang, J., Luo, J.-R., Liu, L., Khan, A., Zhang, L.-C., Xia, C.-F. \& Luo, X.-D. (2018). Org. Lett. 20, 4116-4120.

Zhao, C., Zhao, Y., Chai, H. \& Gong, P. (2006). Bioorg. Med. Chem. 14, 2552-2558.

Zhao, S.-Q., Xu, Y., Guan, J., Zhao, S., Zhang, G.-D. \& Xu, Z. (2018). J. Heterocycl. Chem. 55, 2172-2177. 


\section{supporting information}

Acta Cryst. (2020). C76, 44-63 [https://doi.org/10.1107/S2053229619015687]

Synthesis, crystal structures, antiproliferative activities and reverse docking studies of eight novel Schiff bases derived from benzil

Xue-Jie Tan, Di Wang, Xiao-Ming Hei, Feng-Cun Yang, Ya-Ling Zhu, Dian-Xiang Xing and JianPing Ma

\section{Computing details}

For all structures, data collection: SMART (Bruker, 2000); cell refinement: SMART (Bruker, 2000); data reduction: SAINT (Bruker, 2000); program(s) used to solve structure: SHELXS2016 (Sheldrick, 2015a); program(s) used to refine structure: SHELXL2016 (Sheldrick, 2015b); molecular graphics: SHELXTL (Bruker, 2000), PLATON (Spek, 2009) and DIAMOND (Brandenburg \& Putz, 1999); software used to prepare material for publication: SHELXL2016 (Sheldrick, 2015b) and Win $G X$ (Farrugia, 2012).

(1Z,2Z)-1,2-Bis\{(E)-[(1H-indol-3-yl)methylidene]hydrazinylidene\}-1,2-diphenylethane (1-BDHFI)

Crystal data

$\mathrm{C}_{32} \mathrm{H}_{24} \mathrm{~N}_{6}$

$M_{r}=492.57$

Monoclinic, $P 2_{1} / c$

$a=13.023(4) \AA$

$b=7.340(2) \AA$

$c=27.762(9) \AA$

$\beta=97.693(5)^{\circ}$

$V=2630.0(14) \AA^{3}$

$Z=4$

Data collection

Bruker SMART CCD area detector diffractometer

Radiation source: fine-focus sealed tube Detector resolution: 10.13 pixels $\mathrm{mm}^{-1}$ phi and $\omega$ scans

Absorption correction: multi-scan

(SADABS; Bruker, 2000)

$T_{\min }=0.903, T_{\max }=0.939$

Refinement

Refinement on $F^{2}$

Least-squares matrix: full

$R\left[F^{2}>2 \sigma\left(F^{2}\right)\right]=0.049$

$w R\left(F^{2}\right)=0.103$

$S=0.88$

5145 reflections
$F(000)=1032$

$D_{\mathrm{x}}=1.244 \mathrm{Mg} \mathrm{m}^{-3}$

Mo $K \alpha$ radiation, $\lambda=0.71073 \AA$

Cell parameters from 380 reflections

$\theta=2.5-26.0^{\circ}$

$\mu=0.08 \mathrm{~mm}^{-1}$

$T=293 \mathrm{~K}$

Block, yellow

$0.30 \times 0.18 \times 0.15 \mathrm{~mm}$

13632 measured reflections

5145 independent reflections

2852 reflections with $I>2 \sigma(I)$

$R_{\text {int }}=0.046$

$\theta_{\text {max }}=26.0^{\circ}, \theta_{\min }=1.5^{\circ}$

$h=-16 \rightarrow 13$

$k=-8 \rightarrow 9$

$l=-33 \rightarrow 34$

367 parameters

0 restraints

Hydrogen site location: inferred from neighbouring sites

Only H-atom displacement parameters refined 
$w=1 /\left[\sigma^{2}\left(F_{\mathrm{o}}^{2}\right)+(0.0408 P)^{2}\right]$

where $P=\left(F_{\mathrm{o}}^{2}+2 F_{\mathrm{c}}^{2}\right) / 3$

$(\Delta / \sigma)_{\max }<0.001$

$$
\Delta \rho_{\max }=0.15 \text { e } \AA^{-3}
$$

$\Delta \rho_{\min }=-0.22$ e $\AA^{-3}$

\section{Special details}

Geometry. All esds (except the esd in the dihedral angle between two 1.s. planes) are estimated using the full covariance matrix. The cell esds are taken into account individually in the estimation of esds in distances, angles and torsion angles; correlations between esds in cell parameters are only used when they are defined by crystal symmetry. An approximate (isotropic) treatment of cell esds is used for estimating esds involving l.s. planes.

Refinement. Refinement of $\mathrm{F}^{2}$ against ALL reflections. The weighted R-factor $\mathrm{wR}$ and goodness of fit $\mathrm{S}$ are based on $\mathrm{F}^{2}$, conventional R-factors $R$ are based on $F$, with $F$ set to zero for negative $\mathrm{F}^{2}$. The threshold expression of $\mathrm{F}^{2}>2 \operatorname{sigma}\left(\mathrm{F}^{2}\right)$ is used only for calculating R-factors(gt) etc. and is not relevant to the choice of reflections for refinement. R-factors based on $\mathrm{F}^{2}$ are statistically about twice as large as those based on F, and R- factors based on ALL data will be even larger.

Fractional atomic coordinates and isotropic or equivalent isotropic displacement parameters $\left(\hat{A}^{2}\right)$

\begin{tabular}{lllll}
\hline & $x$ & $y$ & $z$ & $U_{\text {iso }} / U_{\text {eq }}$ \\
\hline C1 & $0.83514(13)$ & $0.3197(2)$ & $0.09431(6)$ & $0.0363(4)$ \\
C2 & $0.92588(13)$ & $0.2300(2)$ & $0.07841(6)$ & $0.0378(5)$ \\
C3 & $0.94898(15)$ & $0.0495(3)$ & $0.08906(7)$ & $0.0474(5)$ \\
H3 & 0.904843 & -0.018427 & 0.105749 & $0.060(6)^{*}$ \\
C4 & $1.03531(16)$ & $-0.0314(3)$ & $0.07558(8)$ & $0.0600(6)$ \\
H4 & 1.049033 & -0.153332 & 0.082980 & $0.069(7)^{*}$ \\
C5 & $1.10143(19)$ & $0.0661(3)$ & $0.05130(8)$ & $0.0713(7)$ \\
H5 & 1.160256 & 0.011204 & 0.042183 & $0.084(8)^{*}$ \\
C6 & $1.08036(19)$ & $0.2454(4)$ & $0.04047(9)$ & $0.0768(7)$ \\
H6 & 1.125208 & 0.312545 & 0.023980 & $0.089(8)^{*}$ \\
C7 & $0.99353(16)$ & $0.3268(3)$ & $0.05380(7)$ & $0.0592(6)$ \\
H7 & 0.980068 & 0.448615 & 0.046176 & $0.051(6)^{*}$ \\
C8 & $0.82392(13)$ & $0.5230(2)$ & $0.08899(6)$ & $0.0377(4)$ \\
C9 & $0.74742(14)$ & $0.5987(3)$ & $0.05028(7)$ & $0.0437(5)$ \\
C10 & $0.70293(18)$ & $0.4886(4)$ & $0.01317(8)$ & $0.0734(7)$ \\
H10 & 0.720298 & 0.365746 & 0.013003 & $0.079(8)^{*}$ \\
C11 & $0.6329(2)$ & $0.5586(5)$ & $-0.02378(10)$ & $0.1124(11)$ \\
H11 & 0.603863 & 0.483089 & -0.048881 & $0.153(13)^{*}$ \\
C12 & $0.6059(2)$ & $0.7378(5)$ & $-0.02370(11)$ & $0.1102(11)$ \\
H12 & 0.558179 & 0.784282 & -0.048581 & $0.119(10)^{*}$ \\
C13 & $0.64870(18)$ & $0.8485(4)$ & $0.01274(10)$ & $0.0823(8)$ \\
H13 & 0.630452 & 0.970999 & 0.012709 & $0.077(8)^{*}$ \\
C14 & $0.71892(15)$ & $0.7801(3)$ & $0.04968(8)$ & $0.0580(6)$ \\
H14 & 0.747607 & 0.856790 & 0.074567 & $0.066(7)^{*}$ \\
C15 & $0.99888(13)$ & $0.6384(3)$ & $0.18379(7)$ & $0.0411(5)$ \\
H15 & 0.984927 & 0.762714 & 0.183158 & $0.046(5)^{*}$ \\
C16 & $1.07404(13)$ & $0.5654(2)$ & $0.22132(6)$ & $0.0385(5)$ \\
C17 & $1.12335(12)$ & $0.3906(3)$ & $0.22344(6)$ & $0.0369(4)$ \\
C18 & $1.12274(14)$ & $0.2432(3)$ & $0.19159(7)$ & $0.0439(5)$ \\
H18 & 1.084885 & 0.248467 & 0.160739 & $0.042(5)^{*}$ \\
C19 & $1.17878(15)$ & $0.0908(3)$ & $0.20652(8)$ & $0.0539(6)$ \\
H19 & 1.177756 & -0.008483 & 0.185639 & $0.058(6)^{*}$ \\
& & & &
\end{tabular}




$\begin{array}{lllll}\text { C20 } & 1.23696(15) & 0.0810(3) & 0.25202(8) & 0.0580(6) \\ \text { H20 } & 1.274298 & -0.024387 & 0.261014 & 0.061(6)^{*} \\ \text { C21 } & 1.24053(15) & 0.2222(3) & 0.28373(8) & 0.0544(6) \\ \text { H21 } & 1.280095 & 0.215710 & 0.314160 & 0.055(6)^{*} \\ \text { C22 } & 1.18325(13) & 0.3765(3) & 0.26927(7) & 0.0416(5) \\ \text { C23 } & 1.10613(14) & 0.6476(3) & 0.26490(7) & 0.0486(5) \\ \text { H23 } & 1.086467 & 0.763553 & 0.273594 & 0.043(5)^{*} \\ \text { C24 } & 0.62285(14) & 0.2475(3) & 0.14849(7) & 0.0484(5) \\ \text { H24 } & 0.634232 & 0.123968 & 0.154452 & 0.048(6)^{*} \\ \text { C25 } & 0.53425(14) & 0.3321(3) & 0.16411(7) & 0.0505(5) \\ \text { C26 } & 0.49308(14) & 0.5105(3) & 0.15329(7) & 0.0505(5) \\ \text { C27 } & 0.52005(16) & 0.6557(3) & 0.12573(8) & 0.0562(6) \\ \text { H27 } & 0.579267 & 0.650487 & 0.110411 & 0.052(6)^{*} \\ \text { C28 } & 0.45807(19) & 0.8070(3) & 0.12143(10) & 0.0786(7) \\ \text { H28 } & 0.476153 & 0.905300 & 0.103174 & 0.076(8)^{*} \\ \text { C29 } & 0.3689(2) & 0.8173(4) & 0.14363(12) & 0.1049(10) \\ \text { H29 } & 0.328037 & 0.921466 & 0.139702 & 0.122(10)^{*} \\ \text { C30 } & 0.3405(2) & 0.6771(4) & 0.17108(12) & 0.1036(10) \\ \text { H30 } & 0.281159 & 0.683543 & 0.186279 & 0.101(9)^{*} \\ \text { C31 } & 0.40318(18) & 0.5254(4) & 0.17543(10) & 0.0733(7) \\ \text { C32 } & 0.46970(18) & 0.2500(4) & 0.19247(9) & 0.0773(7) \\ \text { H32 } & 0.477661 & 0.132346 & 0.204873 & 0.071(7)^{*} \\ \text { N1 } & 0.76775(11) & 0.2260(2) & 0.11353(5) & 0.0405(4) \\ \text { N2 } & 0.68695(11) & 0.3368(2) & 0.12654(5) & 0.0433(4) \\ \text { N3 } & 0.88012(11) & 0.6319(2) & 0.11766(5) & 0.0419(4) \\ \text { N4 } & 0.95074(11) & 0.5349(2) & 0.15116(5) & 0.0432(4) \\ \text { N5 } & 1.17037(12) & 0.5365(2) & 0.29348(6) & 0.0519(5) \\ \text { H35 } & 1.198934 & 0.561788 & 0.322448 & 0.065(7)^{*} \\ \text { N6 } & 0.39279(16) & 0.3652(3) & 0.19973(9) & 0.0954(8) \\ \text { H36 } & 0.344338 & 0.341855 & 0.217039 & 0.103(9)^{*}\end{array}$

Atomic displacement parameters $\left(\AA^{2}\right)$

\begin{tabular}{lllllll}
\hline & $U^{11}$ & $U^{22}$ & $U^{33}$ & $U^{12}$ & $U^{13}$ & $U^{23}$ \\
\hline C1 & $0.0382(11)$ & $0.0372(11)$ & $0.0317(10)$ & $-0.0033(9)$ & $-0.0014(9)$ & $0.0022(9)$ \\
C2 & $0.0403(11)$ & $0.0408(12)$ & $0.0317(10)$ & $-0.0045(9)$ & $0.0029(9)$ & $0.0017(9)$ \\
C3 & $0.0471(12)$ & $0.0435(13)$ & $0.0517(12)$ & $-0.0016(10)$ & $0.0076(10)$ & $-0.0016(11)$ \\
C4 & $0.0624(15)$ & $0.0486(15)$ & $0.0702(16)$ & $0.0082(12)$ & $0.0130(12)$ & $-0.0046(12)$ \\
C5 & $0.0667(17)$ & $0.0754(18)$ & $0.0768(17)$ & $0.0164(15)$ & $0.0276(14)$ & $-0.0022(15)$ \\
C6 & $0.0735(17)$ & $0.0847(19)$ & $0.0810(18)$ & $0.0034(15)$ & $0.0430(15)$ & $0.0145(16)$ \\
C7 & $0.0676(15)$ & $0.0539(15)$ & $0.0602(14)$ & $0.0078(12)$ & $0.0244(12)$ & $0.0141(12)$ \\
C8 & $0.0348(10)$ & $0.0393(12)$ & $0.0395(11)$ & $-0.0019(9)$ & $0.0063(9)$ & $0.0061(9)$ \\
C9 & $0.0402(11)$ & $0.0441(12)$ & $0.0460(12)$ & $-0.0054(10)$ & $0.0029(9)$ & $0.0133(10)$ \\
C10 & $0.0896(19)$ & $0.0590(17)$ & $0.0626(15)$ & $-0.0068(14)$ & $-0.0226(14)$ & $0.0078(13)$ \\
C11 & $0.139(3)$ & $0.095(2)$ & $0.084(2)$ & $-0.016(2)$ & $-0.059(2)$ & $0.0148(19)$ \\
C12 & $0.100(2)$ & $0.109(3)$ & $0.104(2)$ & $-0.008(2)$ & $-0.0505(19)$ & $0.045(2)$ \\
C13 & $0.0655(16)$ & $0.0687(19)$ & $0.107(2)$ & $0.0087(15)$ & $-0.0107(15)$ & $0.0384(17)$ \\
C14 & $0.0476(13)$ & $0.0526(14)$ & $0.0711(15)$ & $-0.0012(11)$ & $-0.0019(12)$ & $0.0162(13)$
\end{tabular}




$\begin{array}{lllllll}\text { C15 } & 0.0357(11) & 0.0341(12) & 0.0541(13) & 0.0003(9) & 0.0086(10) & -0.0037(10) \\ \text { C16 } & 0.0303(10) & 0.0425(12) & 0.0421(11) & -0.0002(9) & 0.0028(9) & -0.0082(10) \\ \text { C17 } & 0.0279(10) & 0.0447(12) & 0.0384(11) & -0.0037(9) & 0.0052(8) & -0.0024(9) \\ \text { C18 } & 0.0381(11) & 0.0480(13) & 0.0445(12) & 0.0010(10) & 0.0016(9) & -0.0051(10) \\ \text { C19 } & 0.0461(13) & 0.0457(13) & 0.0700(15) & 0.0040(11) & 0.0084(11) & -0.0045(13) \\ \text { C20 } & 0.0451(13) & 0.0558(15) & 0.0730(16) & 0.0089(12) & 0.0069(12) & 0.0171(13) \\ \text { C21 } & 0.0378(12) & 0.0779(17) & 0.0457(13) & 0.0011(12) & -0.0010(10) & 0.0176(13) \\ \text { C22 } & 0.0323(10) & 0.0540(13) & 0.0388(11) & -0.0034(10) & 0.0059(9) & 0.0001(10) \\ \text { C23 } & 0.0365(11) & 0.0500(14) & 0.0592(13) & -0.0020(10) & 0.0054(10) & -0.0159(11) \\ \text { C24 } & 0.0394(12) & 0.0478(14) & 0.0568(13) & -0.0046(10) & 0.0017(10) & 0.0080(11) \\ \text { C25 } & 0.0363(12) & 0.0561(14) & 0.0599(14) & -0.0085(11) & 0.0097(10) & 0.0034(11) \\ \text { C26 } & 0.0360(12) & 0.0565(14) & 0.0593(14) & -0.0070(10) & 0.0076(10) & -0.0086(12) \\ \text { C27 } & 0.0464(13) & 0.0570(15) & 0.0650(15) & -0.0012(12) & 0.0071(11) & -0.0049(12) \\ \text { C28 } & 0.0728(18) & 0.0533(16) & 0.112(2) & 0.0033(14) & 0.0201(16) & -0.0005(16) \\ \text { C29 } & 0.078(2) & 0.070(2) & 0.173(3) & 0.0164(18) & 0.040(2) & -0.009(2) \\ \text { C30 } & 0.0711(19) & 0.083(2) & 0.169(3) & 0.0079(17) & 0.061(2) & -0.018(2) \\ \text { C31 } & 0.0542(15) & 0.0665(17) & 0.105(2) & -0.0063(14) & 0.0320(14) & -0.0091(16) \\ \text { C32 } & 0.0602(16) & 0.0682(18) & 0.109(2) & -0.0021(14) & 0.0310(15) & 0.0156(16) \\ \text { N1 } & 0.0377(9) & 0.0403(9) & 0.0432(9) & 0.0002(8) & 0.0047(8) & 0.0053(8) \\ \text { N2 } & 0.0371(9) & 0.0443(10) & 0.0486(10) & -0.0012(8) & 0.0064(8) & 0.0054(8) \\ \text { N3 } & 0.0391(9) & 0.0377(10) & 0.0472(9) & 0.0001(8) & -0.0012(8) & 0.0063(8) \\ \text { N4 } & 0.0424(9) & 0.0375(9) & 0.0471(10) & 0.0013(8) & -0.0034(8) & 0.0011(8) \\ \text { N5 } & 0.0405(10) & 0.0736(13) & 0.0397(10) & -0.0041(9) & -0.0013(8) & -0.0112(10) \\ \text { N6 } & 0.0672(14) & 0.0917(18) & 0.141(2) & -0.0066(13) & 0.0629(15) & 0.0055(16) \\ & & & & & & \end{array}$

Geometric parameters $\left(\AA,{ }^{\circ}\right)$

\begin{tabular}{llll}
\hline $\mathrm{C} 1-\mathrm{N} 1$ & $1.286(2)$ & $\mathrm{C} 18-\mathrm{C} 19$ & $1.370(2)$ \\
$\mathrm{C} 1-\mathrm{C} 2$ & $1.471(2)$ & $\mathrm{C} 18-\mathrm{H} 18$ & 0.9300 \\
$\mathrm{C} 1-\mathrm{C} 8$ & $1.505(2)$ & $\mathrm{C} 19-\mathrm{C} 20$ & $1.385(3)$ \\
$\mathrm{C} 2-\mathrm{C} 7$ & $1.382(2)$ & $\mathrm{C} 19-\mathrm{H} 19$ & 0.9300 \\
$\mathrm{C} 2-\mathrm{C} 3$ & $1.382(2)$ & $\mathrm{C} 20-\mathrm{C} 21$ & $1.357(3)$ \\
$\mathrm{C} 3-\mathrm{C} 4$ & $1.367(3)$ & $\mathrm{C} 20-\mathrm{H} 20$ & 0.9300 \\
$\mathrm{C} 3-\mathrm{H} 3$ & 0.9300 & $\mathrm{C} 21-\mathrm{C} 22$ & $1.386(3)$ \\
$\mathrm{C} 4-\mathrm{C} 5$ & $1.365(3)$ & $\mathrm{C} 21-\mathrm{H} 21$ & 0.9300 \\
$\mathrm{C} 4-\mathrm{H} 4$ & 0.9300 & $\mathrm{C} 22-\mathrm{N} 5$ & $1.374(2)$ \\
$\mathrm{C} 5-\mathrm{C} 6$ & $1.370(3)$ & $\mathrm{C} 23-\mathrm{N} 5$ & $1.348(2)$ \\
$\mathrm{C} 5-\mathrm{H} 5$ & 0.9300 & $\mathrm{C} 23-\mathrm{H} 23$ & 0.9300 \\
$\mathrm{C} 6-\mathrm{C} 7$ & $1.373(3)$ & $\mathrm{C} 24-\mathrm{N} 2$ & $1.278(2)$ \\
$\mathrm{C} 6-\mathrm{H} 6$ & 0.9300 & $\mathrm{C} 24-\mathrm{C} 25$ & $1.428(3)$ \\
$\mathrm{C} 7-\mathrm{H} 7$ & 0.9300 & $\mathrm{C} 24-\mathrm{H} 24$ & 0.9300 \\
$\mathrm{C} 8-\mathrm{N} 3$ & $1.286(2)$ & $\mathrm{C} 25-\mathrm{C} 32$ & $1.367(3)$ \\
$\mathrm{C} 8-\mathrm{C} 9$ & $1.473(2)$ & $\mathrm{C} 25-\mathrm{C} 26$ & $1.431(3)$ \\
$\mathrm{C} 9-\mathrm{C} 10$ & $1.375(3)$ & $\mathrm{C} 26-\mathrm{C} 27$ & $1.384(3)$ \\
$\mathrm{C} 9-\mathrm{C} 14$ & $1.382(3)$ & $\mathrm{C} 26-\mathrm{C} 31$ & $1.398(3)$ \\
$\mathrm{C} 10-\mathrm{C} 11$ & $1.378(3)$ & $\mathrm{C} 27-\mathrm{C} 28$ & $1.369(3)$ \\
$\mathrm{C} 10-\mathrm{H} 10$ & 0.9300 & $\mathrm{C} 27-\mathrm{H} 27$ & 0.9300 \\
$\mathrm{C} 11-\mathrm{C} 12$ & $1.361(4)$ & $\mathrm{C} 28-\mathrm{C} 29$ & $1.387(3)$
\end{tabular}




\begin{tabular}{|c|c|c|c|}
\hline C11-H11 & 0.9300 & $\mathrm{C} 28-\mathrm{H} 28$ & 0.9300 \\
\hline $\mathrm{C} 12-\mathrm{C} 13$ & $1.358(3)$ & $\mathrm{C} 29-\mathrm{C} 30$ & $1.361(4)$ \\
\hline $\mathrm{C} 12-\mathrm{H} 12$ & 0.9300 & $\mathrm{C} 29-\mathrm{H} 29$ & 0.9300 \\
\hline $\mathrm{C} 13-\mathrm{C} 14$ & $1.374(3)$ & $\mathrm{C} 30-\mathrm{C} 31$ & $1.376(3)$ \\
\hline C13-H13 & 0.9300 & $\mathrm{C} 30-\mathrm{H} 30$ & 0.9300 \\
\hline C14-H14 & 0.9300 & $\mathrm{C} 31-\mathrm{N} 6$ & $1.371(3)$ \\
\hline $\mathrm{C} 15-\mathrm{N} 4$ & $1.280(2)$ & $\mathrm{C} 32-\mathrm{N} 6$ & $1.347(3)$ \\
\hline $\mathrm{C} 15-\mathrm{C} 16$ & $1.435(2)$ & C32-H32 & 0.9300 \\
\hline C15-H15 & 0.9300 & $\mathrm{~N} 1-\mathrm{N} 2$ & $1.4146(19)$ \\
\hline $\mathrm{C} 16-\mathrm{C} 23$ & $1.367(2)$ & $\mathrm{N} 3-\mathrm{N} 4$ & $1.4104(18)$ \\
\hline $\mathrm{C} 16-\mathrm{C} 17$ & $1.432(2)$ & N5-H35 & 0.8600 \\
\hline $\mathrm{C} 17-\mathrm{C} 18$ & $1.397(2)$ & N6-H36 & 0.8600 \\
\hline $\mathrm{C} 17-\mathrm{C} 22$ & $1.404(2)$ & & \\
\hline $\mathrm{N} 1-\mathrm{C} 1-\mathrm{C} 2$ & $120.37(17)$ & $\mathrm{C} 17-\mathrm{C} 18-\mathrm{H} 18$ & 120.5 \\
\hline $\mathrm{N} 1-\mathrm{C} 1-\mathrm{C} 8$ & $120.56(16)$ & $\mathrm{C} 18-\mathrm{C} 19-\mathrm{C} 20$ & $121.5(2)$ \\
\hline $\mathrm{C} 2-\mathrm{C} 1-\mathrm{C} 8$ & $119.05(16)$ & $\mathrm{C} 18-\mathrm{C} 19-\mathrm{H} 19$ & 119.2 \\
\hline $\mathrm{C} 7-\mathrm{C} 2-\mathrm{C} 3$ & $117.65(19)$ & $\mathrm{C} 20-\mathrm{C} 19-\mathrm{H} 19$ & 119.2 \\
\hline $\mathrm{C} 7-\mathrm{C} 2-\mathrm{C} 1$ & $120.61(18)$ & $\mathrm{C} 21-\mathrm{C} 20-\mathrm{C} 19$ & $121.3(2)$ \\
\hline $\mathrm{C} 3-\mathrm{C} 2-\mathrm{C} 1$ & $121.69(17)$ & $\mathrm{C} 21-\mathrm{C} 20-\mathrm{H} 20$ & 119.4 \\
\hline $\mathrm{C} 4-\mathrm{C} 3-\mathrm{C} 2$ & $121.4(2)$ & $\mathrm{C} 19-\mathrm{C} 20-\mathrm{H} 20$ & 119.4 \\
\hline $\mathrm{C} 4-\mathrm{C} 3-\mathrm{H} 3$ & 119.3 & $\mathrm{C} 20-\mathrm{C} 21-\mathrm{C} 22$ & $117.78(19)$ \\
\hline $\mathrm{C} 2-\mathrm{C} 3-\mathrm{H} 3$ & 119.3 & $\mathrm{C} 20-\mathrm{C} 21-\mathrm{H} 21$ & 121.1 \\
\hline $\mathrm{C} 5-\mathrm{C} 4-\mathrm{C} 3$ & $120.2(2)$ & $\mathrm{C} 22-\mathrm{C} 21-\mathrm{H} 21$ & 121.1 \\
\hline $\mathrm{C} 5-\mathrm{C} 4-\mathrm{H} 4$ & 119.9 & $\mathrm{~N} 5-\mathrm{C} 22-\mathrm{C} 21$ & $130.74(18)$ \\
\hline $\mathrm{C} 3-\mathrm{C} 4-\mathrm{H} 4$ & 119.9 & $\mathrm{~N} 5-\mathrm{C} 22-\mathrm{C} 17$ & $106.91(17)$ \\
\hline $\mathrm{C} 4-\mathrm{C} 5-\mathrm{C} 6$ & $119.4(2)$ & $\mathrm{C} 21-\mathrm{C} 22-\mathrm{C} 17$ & $122.34(19)$ \\
\hline $\mathrm{C} 4-\mathrm{C} 5-\mathrm{H} 5$ & 120.3 & $\mathrm{~N} 5-\mathrm{C} 23-\mathrm{C} 16$ & $110.24(18)$ \\
\hline $\mathrm{C} 6-\mathrm{C} 5-\mathrm{H} 5$ & 120.3 & $\mathrm{~N} 5-\mathrm{C} 23-\mathrm{H} 23$ & 124.9 \\
\hline $\mathrm{C} 5-\mathrm{C} 6-\mathrm{C} 7$ & $120.5(2)$ & $\mathrm{C} 16-\mathrm{C} 23-\mathrm{H} 23$ & 124.9 \\
\hline $\mathrm{C} 5-\mathrm{C} 6-\mathrm{H} 6$ & 119.8 & $\mathrm{~N} 2-\mathrm{C} 24-\mathrm{C} 25$ & $121.8(2)$ \\
\hline $\mathrm{C} 7-\mathrm{C} 6-\mathrm{H} 6$ & 119.8 & $\mathrm{~N} 2-\mathrm{C} 24-\mathrm{H} 24$ & 119.1 \\
\hline $\mathrm{C} 6-\mathrm{C} 7-\mathrm{C} 2$ & $120.8(2)$ & $\mathrm{C} 25-\mathrm{C} 24-\mathrm{H} 24$ & 119.1 \\
\hline $\mathrm{C} 6-\mathrm{C} 7-\mathrm{H} 7$ & 119.6 & $\mathrm{C} 32-\mathrm{C} 25-\mathrm{C} 24$ & $124.6(2)$ \\
\hline $\mathrm{C} 2-\mathrm{C} 7-\mathrm{H} 7$ & 119.6 & $\mathrm{C} 32-\mathrm{C} 25-\mathrm{C} 26$ & $106.42(19)$ \\
\hline $\mathrm{N} 3-\mathrm{C} 8-\mathrm{C} 9$ & $119.37(17)$ & $\mathrm{C} 24-\mathrm{C} 25-\mathrm{C} 26$ & $129.00(19)$ \\
\hline $\mathrm{N} 3-\mathrm{C} 8-\mathrm{C} 1$ & $121.09(16)$ & $\mathrm{C} 27-\mathrm{C} 26-\mathrm{C} 31$ & $118.2(2)$ \\
\hline $\mathrm{C} 9-\mathrm{C} 8-\mathrm{C} 1$ & $119.54(16)$ & $\mathrm{C} 27-\mathrm{C} 26-\mathrm{C} 25$ & $134.79(19)$ \\
\hline $\mathrm{C} 10-\mathrm{C} 9-\mathrm{C} 14$ & $118.1(2)$ & $\mathrm{C} 31-\mathrm{C} 26-\mathrm{C} 25$ & $107.0(2)$ \\
\hline $\mathrm{C} 10-\mathrm{C} 9-\mathrm{C} 8$ & 120.07 (19) & $\mathrm{C} 28-\mathrm{C} 27-\mathrm{C} 26$ & $118.9(2)$ \\
\hline $\mathrm{C} 14-\mathrm{C} 9-\mathrm{C} 8$ & $121.78(19)$ & $\mathrm{C} 28-\mathrm{C} 27-\mathrm{H} 27$ & 120.6 \\
\hline $\mathrm{C} 9-\mathrm{C} 10-\mathrm{C} 11$ & $120.6(3)$ & $\mathrm{C} 26-\mathrm{C} 27-\mathrm{H} 27$ & 120.6 \\
\hline $\mathrm{C} 9-\mathrm{C} 10-\mathrm{H} 10$ & 119.7 & $\mathrm{C} 27-\mathrm{C} 28-\mathrm{C} 29$ & $121.6(3)$ \\
\hline $\mathrm{C} 11-\mathrm{C} 10-\mathrm{H} 10$ & 119.7 & $\mathrm{C} 27-\mathrm{C} 28-\mathrm{H} 28$ & 119.2 \\
\hline $\mathrm{C} 12-\mathrm{C} 11-\mathrm{C} 10$ & $120.3(3)$ & $\mathrm{C} 29-\mathrm{C} 28-\mathrm{H} 28$ & 119.2 \\
\hline $\mathrm{C} 12-\mathrm{C} 11-\mathrm{H} 11$ & 119.9 & $\mathrm{C} 30-\mathrm{C} 29-\mathrm{C} 28$ & $120.9(3)$ \\
\hline $\mathrm{C} 10-\mathrm{C} 11-\mathrm{H} 11$ & 119.9 & $\mathrm{C} 30-\mathrm{C} 29-\mathrm{H} 29$ & 119.5 \\
\hline $\mathrm{C} 13-\mathrm{C} 12-\mathrm{C} 11$ & $119.9(3)$ & $\mathrm{C} 28-\mathrm{C} 29-\mathrm{H} 29$ & 119.5 \\
\hline
\end{tabular}




$\begin{array}{ll}\mathrm{C} 13-\mathrm{C} 12-\mathrm{H} 12 & 120.0 \\ \mathrm{C} 11-\mathrm{C} 12-\mathrm{H} 12 & 120.0 \\ \mathrm{C} 12-\mathrm{C} 13-\mathrm{C} 14 & 120.2(3) \\ \mathrm{C} 12-\mathrm{C} 13-\mathrm{H} 13 & 119.9 \\ \mathrm{C} 14-\mathrm{C} 13-\mathrm{H} 13 & 119.9 \\ \mathrm{C} 13-\mathrm{C} 14-\mathrm{C} 9 & 120.8(2) \\ \mathrm{C} 13-\mathrm{C} 14-\mathrm{H} 14 & 119.6 \\ \mathrm{C} 9-\mathrm{C} 14-\mathrm{H} 14 & 119.6 \\ \mathrm{~N} 4-\mathrm{C} 15-\mathrm{C} 16 & 120.91(17) \\ \mathrm{N} 4-\mathrm{C} 15-\mathrm{H} 15 & 119.5 \\ \mathrm{C} 16-\mathrm{C} 15-\mathrm{H} 15 & 119.5 \\ \mathrm{C} 23-\mathrm{C} 16-\mathrm{C} 17 & 106.07(16) \\ \mathrm{C} 23-\mathrm{C} 16-\mathrm{C} 15 & 125.16(17) \\ \mathrm{C} 17-\mathrm{C} 16-\mathrm{C} 15 & 128.56(16) \\ \mathrm{C} 18-\mathrm{C} 17-\mathrm{C} 22 & 118.16(17) \\ \mathrm{C} 18-\mathrm{C} 17-\mathrm{C} 16 & 134.69(17) \\ \mathrm{C} 22-\mathrm{C} 17-\mathrm{C} 16 & 107.15(16) \\ \mathrm{C} 19-\mathrm{C} 18-\mathrm{C} 17 & 118.92(18) \\ \mathrm{C} 19-\mathrm{C} 18-\mathrm{H} 18 & 120.5\end{array}$

$\begin{array}{ll}\mathrm{C} 29-\mathrm{C} 30-\mathrm{C} 31 & 117.3(3) \\ \mathrm{C} 29-\mathrm{C} 30-\mathrm{H} 30 & 121.4 \\ \mathrm{C} 31-\mathrm{C} 30-\mathrm{H} 30 & 121.4 \\ \mathrm{~N} 6-\mathrm{C} 31-\mathrm{C} 30 & 129.8(2) \\ \mathrm{N} 6-\mathrm{C} 31-\mathrm{C} 26 & 107.0(2) \\ \mathrm{C} 30-\mathrm{C} 31-\mathrm{C} 26 & 123.2(3) \\ \mathrm{N} 6-\mathrm{C} 32-\mathrm{C} 25 & 109.6(2) \\ \mathrm{N} 6-\mathrm{C} 32-\mathrm{H} 32 & 125.2 \\ \mathrm{C} 25-\mathrm{C} 32-\mathrm{H} 32 & 125.2 \\ \mathrm{C} 1-\mathrm{N} 1-\mathrm{N} 2 & 111.77(15) \\ \mathrm{C} 24-\mathrm{N} 2-\mathrm{N} 1 & 112.49(16) \\ \mathrm{C} 8-\mathrm{N} 3-\mathrm{N} 4 & 111.16(15) \\ \mathrm{C} 15-\mathrm{N} 4-\mathrm{N} 3 & 112.39(15) \\ \mathrm{C} 23-\mathrm{N} 5-\mathrm{C} 22 & 109.62(16) \\ \mathrm{C} 23-\mathrm{N} 5-\mathrm{H} 35 & 125.2 \\ \mathrm{C} 22-\mathrm{N} 5-\mathrm{H} 35 & 125.2 \\ \mathrm{C} 32-\mathrm{N} 6-\mathrm{C} 31 & 109.9(2) \\ \mathrm{C} 32-\mathrm{N} 6-\mathrm{H} 36 & 125.0 \\ \mathrm{C} 31-\mathrm{N} 6-\mathrm{H} 36 & 125.0\end{array}$

Hydrogen-bond geometry $\left(\AA,{ }^{o}\right)$

\begin{tabular}{lllll}
\hline$D-\mathrm{H} \cdots A$ & $D-\mathrm{H}$ & $\mathrm{H} \cdots A$ & $D \cdots A$ & $D-\mathrm{H} \cdots A$ \\
\hline $\mathrm{N} 5-\mathrm{H} 35 \cdots \mathrm{N} 1^{\mathrm{i}}$ & 0.86 & 2.14 & $2.948(2)$ & 156 \\
$\mathrm{C} 3-\mathrm{H} 3 \cdots \mathrm{N} 3{ }^{i i}$ & 0.93 & 2.61 & $3.320(3)$ & 133 \\
\hline
\end{tabular}

Symmetry codes: (i) $-x+2, y+1 / 2,-z+1 / 2$; (ii) $x, y-1, z$.

(1Z,2Z)-1,2-Bis\{(E)-[1-(1H-indol-3-yl)ethylidene]hydrazinylidene\}-1,2-diphenylethane (2-BDHAI)

\section{Crystal data}

$\mathrm{C}_{34} \mathrm{H}_{28} \mathrm{~N}_{6}$

$M_{r}=520.62$

Triclinic, $P \overline{1}$

$a=10.2585(4) \AA$

$b=11.9610(5) \AA$

$c=12.8232(6) \AA$

$\alpha=64.941(4)^{\circ}$

$\beta=79.573(3)^{\circ}$

$\gamma=76.829(4)^{\circ}$

$V=1381.45(11) \AA^{3}$

\section{Data collection}

Bruker SMART CCD area detector diffractometer

Radiation source: fine-focus sealed tube Detector resolution: 10.13 pixels $\mathrm{mm}^{-1}$ phi and $\omega$ scans

Absorption correction: multi-scan

(SADABS; Bruker, 2000)

$T_{\min }=0.903, T_{\max }=0.939$
$Z=2$

$F(000)=548$

$D_{\mathrm{x}}=1.252 \mathrm{Mg} \mathrm{m}^{-3}$

Mo $K \alpha$ radiation, $\lambda=0.71073 \AA$

Cell parameters from 380 reflections

$\theta=2.5-26.0^{\circ}$

$\mu=0.08 \mathrm{~mm}^{-1}$

$T=293 \mathrm{~K}$

Bar, yellow

$0.35 \times 0.15 \times 0.12 \mathrm{~mm}$

15195 measured reflections 5328 independent reflections 4490 reflections with $I>2 \sigma(I)$

$R_{\text {int }}=0.026$

$\theta_{\text {max }}=26.0^{\circ}, \theta_{\text {min }}=1.8^{\circ}$

$h=-12 \rightarrow 12$

$k=-14 \rightarrow 14$

$l=-13 \rightarrow 15$ 


\section{Refinement}

Refinement on $F^{2}$

Least-squares matrix: full

$R\left[F^{2}>2 \sigma\left(F^{2}\right)\right]=0.044$

$w R\left(F^{2}\right)=0.129$

$S=1.05$

5328 reflections

392 parameters

0 restraints

Hydrogen site location: inferred from neighbouring sites
Only $\mathrm{H}$-atom displacement parameters refined

$w=1 /\left[\sigma^{2}\left(F_{\mathrm{o}}^{2}\right)+(0.0694 P)^{2}+0.1725 P\right]$ where $P=\left(F_{\mathrm{o}}{ }^{2}+2 F_{\mathrm{c}}{ }^{2}\right) / 3$

$(\Delta / \sigma)_{\max }<0.001$

$\Delta \rho_{\max }=0.19 \mathrm{e} \AA^{-3}$

$\Delta \rho_{\min }=-0.18 \mathrm{e} \AA^{-3}$

Extinction correction: SHELXL2016 (Sheldrick, 2015b), $\mathrm{Fc}^{*}=\mathrm{kFc}\left[1+0.001 \mathrm{xFc}^{2} \lambda^{3} / \sin (2 \theta)\right]^{-1 / 4}$

Extinction coefficient: 0.083 (4)

Special details

Geometry. All esds (except the esd in the dihedral angle between two 1.s. planes) are estimated using the full covariance matrix. The cell esds are taken into account individually in the estimation of esds in distances, angles and torsion angles; correlations between esds in cell parameters are only used when they are defined by crystal symmetry. An approximate (isotropic) treatment of cell esds is used for estimating esds involving l.s. planes.

Refinement. Refinement of $\mathrm{F}^{2}$ against ALL reflections. The weighted R-factor $\mathrm{wR}$ and goodness of fit $\mathrm{S}$ are based on $\mathrm{F}^{2}$, conventional R-factors $R$ are based on $F$, with $F$ set to zero for negative $F^{2}$. The threshold expression of $\mathrm{F}^{2}>2 \operatorname{sigma}\left(\mathrm{F}^{2}\right)$ is used only for calculating R-factors(gt) etc. and is not relevant to the choice of reflections for refinement. R-factors based on $\mathrm{F}^{2}$ are statistically about twice as large as those based on F, and R- factors based on ALL data will be even larger.

Fractional atomic coordinates and isotropic or equivalent isotropic displacement parameters $\left(\AA^{2}\right)$

\begin{tabular}{|c|c|c|c|c|}
\hline & $x$ & $y$ & $z$ & $U_{\text {iso }} * / U_{\text {eq }}$ \\
\hline $\mathrm{C} 1$ & $0.21600(13)$ & $0.84926(13)$ & $0.45306(11)$ & $0.0462(3)$ \\
\hline $\mathrm{C} 2$ & $0.24638(13)$ & $0.97764(13)$ & $0.38744(12)$ & $0.0491(3)$ \\
\hline $\mathrm{C} 3$ & $0.15001(16)$ & $1.07464(15)$ & $0.32585(16)$ & $0.0648(4)$ \\
\hline $\mathrm{H} 2$ & 0.067148 & 1.057647 & 0.322519 & $0.081(6)^{*}$ \\
\hline $\mathrm{C} 4$ & $0.17520(19)$ & $1.19565(16)$ & $0.26959(17)$ & $0.0746(5)$ \\
\hline $\mathrm{H} 3$ & 0.109933 & 1.259075 & 0.227799 & $0.097(7)^{*}$ \\
\hline $\mathrm{C} 5$ & $0.2954(2)$ & $1.22291(17)$ & $0.27488(16)$ & $0.0739(5)$ \\
\hline $\mathrm{H} 4$ & 0.311226 & 1.304989 & 0.238380 & $0.085(6)^{*}$ \\
\hline C6 & $0.3928(2)$ & $1.12876(18)$ & $0.33426(16)$ & $0.0747(5)$ \\
\hline H5 & 0.474994 & 1.147161 & 0.337453 & $0.092(6)^{*}$ \\
\hline $\mathrm{C} 7$ & $0.36938(16)$ & $1.00565(16)$ & $0.38983(14)$ & $0.0618(4)$ \\
\hline H6 & 0.436524 & 0.942110 & 0.428646 & $0.072(5)^{*}$ \\
\hline $\mathrm{C} 8$ & $0.32668(13)$ & $0.74348(13)$ & $0.50875(12)$ & $0.0483(3)$ \\
\hline C9 & $0.34159(15)$ & $0.70585(14)$ & $0.63212(12)$ & $0.0551(4)$ \\
\hline $\mathrm{C} 10$ & $0.26077(17)$ & $0.77226(18)$ & $0.69346(14)$ & $0.0658(4)$ \\
\hline $\mathrm{H} 7$ & 0.196310 & 0.840386 & 0.656770 & $0.065(5)^{*}$ \\
\hline C11 & $0.2755(2)$ & $0.7377(2)$ & $0.80900(17)$ & 0.0877 (6) \\
\hline $\mathrm{H} 10$ & 0.221187 & 0.782867 & 0.849312 & $0.088(6)^{*}$ \\
\hline $\mathrm{C} 12$ & 0.3700 & $0.6372(3)$ & $0.86403(18)$ & $0.1028(8)$ \\
\hline H12 & 0.379338 & 0.613722 & 0.941672 & $0.113(8)^{*}$ \\
\hline $\mathrm{C} 13$ & $0.4506(3)$ & $0.5713(2)$ & $0.80406(19)$ & $0.0961(7)$ \\
\hline H13 & 0.514323 & 0.502950 & 0.841665 & $0.118(8)^{*}$ \\
\hline C14 & $0.4385(2)$ & $0.60529(17)$ & $0.68842(16)$ & $0.0721(5)$ \\
\hline H11 & 0.495074 & 0.560945 & 0.648337 & $0.099(7)^{*}$ \\
\hline $\mathrm{C} 15$ & $0.49611(13)$ & $0.72877(13)$ & $0.26579(13)$ & $0.0491(3)$ \\
\hline
\end{tabular}




\begin{tabular}{|c|c|c|c|c|}
\hline $\mathrm{C} 16$ & $0.48156(13)$ & $0.78461(14)$ & $0.14310(13)$ & $0.0501(3)$ \\
\hline $\mathrm{C} 17$ & $0.36770(13)$ & $0.86989(13)$ & $0.08418(12)$ & $0.0484(3)$ \\
\hline $\mathrm{C} 18$ & $0.24161(14)$ & $0.92420(14)$ & $0.11937(14)$ & $0.0546(4)$ \\
\hline H18 & 0.214228 & 0.904063 & 0.197491 & $0.058(4)^{*}$ \\
\hline C19 & $0.15878(17)$ & $1.00782(16)$ & $0.03671(16)$ & $0.0668(4)$ \\
\hline H19 & 0.074912 & 1.044421 & 0.059733 & $0.071(5)^{*}$ \\
\hline $\mathrm{C} 20$ & $0.19753(19)$ & 1.03927 (18) & $-0.08130(17)$ & $0.0753(5)$ \\
\hline $\mathrm{H} 20$ & 0.138681 & 1.095426 & -0.135092 & $0.091(6)^{*}$ \\
\hline $\mathrm{C} 21$ & 0.32077 (19) & $0.98860(17)$ & $-0.11877(16)$ & $0.0722(5)$ \\
\hline $\mathrm{H} 21$ & 0.347018 & 1.009515 & -0.197140 & $0.085(6)^{*}$ \\
\hline $\mathrm{C} 22$ & $0.40519(15)$ & $0.90475(15)$ & $-0.03532(14)$ & $0.0580(4)$ \\
\hline $\mathrm{C} 23$ & $0.57959(16)$ & $0.77510(17)$ & $0.05713(15)$ & $0.0646(4)$ \\
\hline $\mathrm{H} 23$ & 0.665006 & 0.727371 & 0.069683 & $0.077(5)^{*}$ \\
\hline $\mathrm{C} 24$ & $-0.03270(14)$ & $0.68082(14)$ & $0.52381(12)$ & $0.0518(3)$ \\
\hline $\mathrm{C} 25$ & $-0.07215(13)$ & 0.56489 (14) & $0.61098(13)$ & $0.0506(3)$ \\
\hline $\mathrm{C} 26$ & $-0.03001(13)$ & $0.49580(13)$ & $0.72570(12)$ & $0.0466(3)$ \\
\hline $\mathrm{C} 27$ & $0.05813(13)$ & $0.51142(13)$ & $0.78861(13)$ & $0.0493(3)$ \\
\hline $\mathrm{H} 27$ & 0.108227 & 0.575950 & 0.754067 & $0.056(4)^{*}$ \\
\hline $\mathrm{C} 28$ & $0.06910(15)$ & $0.42989(14)$ & $0.90189(14)$ & $0.0572(4)$ \\
\hline $\mathrm{H} 28$ & 0.126490 & 0.440283 & 0.944331 & $0.063(4)^{*}$ \\
\hline $\mathrm{C} 29$ & $-0.00429(17)$ & $0.33154(16)$ & $0.95472(15)$ & $0.0654(4)$ \\
\hline $\mathrm{H} 29$ & 0.005442 & 0.277666 & 1.031582 & $0.076(5)^{*}$ \\
\hline $\mathrm{C} 30$ & $-0.09047(17)$ & $0.31280(15)$ & $0.89550(14)$ & $0.0638(4)$ \\
\hline $\mathrm{H} 30$ & -0.139175 & 0.247275 & 0.930808 & $0.067(5)^{*}$ \\
\hline $\mathrm{C} 31$ & $-0.10219(14)$ & $0.39519(14)$ & $0.78113(13)$ & $0.0523(3)$ \\
\hline $\mathrm{C} 32$ & $-0.16427(15)$ & $0.50232(15)$ & $0.60219(14)$ & $0.0587(4)$ \\
\hline H32 & -0.208006 & 0.525861 & 0.536678 & $0.069(5)^{*}$ \\
\hline $\mathrm{C} 33$ & $0.63359(15)$ & $0.6710(2)$ & $0.30611(17)$ & $0.0733(5)$ \\
\hline $\mathrm{H} 33 \mathrm{~A}$ & 0.627256 & 0.598418 & 0.377122 & $0.100(7)^{*}$ \\
\hline H33B & 0.670603 & 0.730677 & 0.318564 & $0.135(10)^{*}$ \\
\hline $\mathrm{H} 33 \mathrm{C}$ & 0.690878 & 0.646881 & 0.248427 & $0.141(10)^{*}$ \\
\hline C34 & $-0.1161(2)$ & $0.7575(2)$ & $0.42427(18)$ & $0.0840(6)$ \\
\hline $\mathrm{H} 34 \mathrm{~A}$ & -0.209716 & 0.760959 & 0.451964 & $0.145(10)^{*}$ \\
\hline H34B & -0.096409 & 0.719957 & 0.369015 & $0.187(15)^{*}$ \\
\hline $\mathrm{H} 34 \mathrm{C}$ & -0.095464 & 0.840849 & 0.388088 & $0.162(12)^{*}$ \\
\hline N1 & $0.09402(11)$ & $0.83288(11)$ & $0.46297(10)$ & $0.0520(3)$ \\
\hline $\mathrm{N} 2$ & 0.07283 & $0.71200(11)$ & $0.53875(10)$ & $0.0511(3)$ \\
\hline N3 & $0.41191(12)$ & $0.68906(12)$ & $0.45120(11)$ & $0.0548(3)$ \\
\hline N4 & $0.38813(11)$ & $0.73680(11)$ & $0.33433(10)$ & $0.0519(3)$ \\
\hline N5 & $0.53458(14)$ & $0.84467(15)$ & $-0.04798(13)$ & $0.0703(4)$ \\
\hline H35 & 0.579886 & 0.850515 & -0.112912 & $0.078(6)^{*}$ \\
\hline N6 & $-0.18231(13)$ & $0.40170(13)$ & $0.70225(12)$ & $0.0616(3)$ \\
\hline H36 & -0.235238 & 0.350076 & 0.714696 & $0.067(5)^{*}$ \\
\hline
\end{tabular}

Atomic displacement parameters $\left(\AA^{2}\right)$

\begin{tabular}{lllllll}
\hline & $U^{11}$ & $U^{22}$ & $U^{33}$ & $U^{12}$ & $U^{13}$ & $U^{23}$ \\
\hline $\mathrm{C} 1$ & $0.0423(7)$ & $0.0552(8)$ & $0.0428(7)$ & $-0.0102(6)$ & $-0.0023(5)$ & $-0.0209(6)$
\end{tabular}




\begin{tabular}{|c|c|c|c|c|c|c|}
\hline $\mathrm{C} 2$ & $0.0477(7)$ & $0.0542(8)$ & $0.0474(7)$ & $-0.0112(6)$ & $0.0035(6)$ & $-0.0240(6)$ \\
\hline $\mathrm{C} 3$ & $0.0527(9)$ & $0.0554(9)$ & $0.0832(12)$ & $-0.0035(7)$ & $-0.0033(8)$ & $-0.0290(8)$ \\
\hline $\mathrm{C} 4$ & $0.0773(12)$ & $0.0530(9)$ & $0.0828(12)$ & $0.0011(8)$ & $-0.0006(9)$ & $-0.0258(9)$ \\
\hline $\mathrm{C} 5$ & $0.0939(13)$ & $0.0564(10)$ & $0.0705(11)$ & $-0.0265(9)$ & $0.0144(10)$ & $-0.0263(9)$ \\
\hline C6 & $0.0774(12)$ & $0.0841(12)$ & $0.0683(11)$ & $-0.0422(10)$ & $0.0061(9)$ & $-0.0267(10)$ \\
\hline $\mathrm{C} 7$ & $0.0584(9)$ & $0.0682(10)$ & $0.0558(9)$ & $-0.0233(8)$ & $-0.0028(7)$ & $-0.0168(8)$ \\
\hline $\mathrm{C} 8$ & $0.0423(7)$ & $0.0525(7)$ & $0.0497(7)$ & $-0.0145(6)$ & $-0.0069(5)$ & $-0.0159(6)$ \\
\hline C9 & $0.0551(8)$ & $0.0637(9)$ & $0.0482(8)$ & $-0.0273(7)$ & $-0.0065(6)$ & $-0.0146(7)$ \\
\hline $\mathrm{C} 10$ & $0.0615(9)$ & $0.0890(12)$ & $0.0559(9)$ & $-0.0315(9)$ & $0.0007(7)$ & $-0.0307(9)$ \\
\hline C11 & $0.0973(15)$ & $0.1285(18)$ & $0.0574(11)$ & $-0.0604(14)$ & $0.0098(10)$ & $-0.0423(12)$ \\
\hline $\mathrm{C} 12$ & $0.135(2)$ & $0.129(2)$ & $0.0500(11)$ & $-0.0707(17)$ & $-0.0199(12)$ & $-0.0125(12)$ \\
\hline C13 & $0.1239(19)$ & $0.0874(14)$ & $0.0670(13)$ & $-0.0360(13)$ & $-0.0424(13)$ & $0.0009(11)$ \\
\hline $\mathrm{C} 14$ & $0.0827(12)$ & $0.0656(10)$ & $0.0621(10)$ & $-0.0199(9)$ & $-0.0247(9)$ & $-0.0091(8)$ \\
\hline $\mathrm{C} 15$ & $0.0371(7)$ & $0.0541(8)$ & $0.0646(9)$ & $-0.0047(5)$ & $-0.0092(6)$ & $-0.0316(7)$ \\
\hline $\mathrm{C} 16$ & $0.0397(7)$ & $0.0592(8)$ & $0.0596(8)$ & $-0.0084(6)$ & $-0.0049(6)$ & $-0.0314(7)$ \\
\hline C17 & $0.0443(7)$ & $0.0536(8)$ & $0.0555(8)$ & $-0.0133(6)$ & $-0.0074(6)$ & $-0.0260(6)$ \\
\hline $\mathrm{C} 18$ & $0.0440(7)$ & $0.0601(9)$ & $0.0617(9)$ & $-0.0089(6)$ & $-0.0080(6)$ & $-0.0249(7)$ \\
\hline C19 & $0.0504(8)$ & $0.0666(10)$ & $0.0792(11)$ & $-0.0039(7)$ & $-0.0157(8)$ & $-0.0245(9)$ \\
\hline $\mathrm{C} 20$ & $0.0709(11)$ & $0.0730(11)$ & $0.0739(12)$ & $-0.0109(9)$ & $-0.0270(9)$ & $-0.0144(9)$ \\
\hline $\mathrm{C} 21$ & $0.0812(12)$ & $0.0785(12)$ & $0.0560(10)$ & $-0.0214(9)$ & $-0.0127(8)$ & $-0.0197(9)$ \\
\hline $\mathrm{C} 22$ & $0.0572(9)$ & $0.0658(9)$ & $0.0582(9)$ & $-0.0174(7)$ & $-0.0040(7)$ & $-0.0287(8)$ \\
\hline $\mathrm{C} 23$ & $0.0454(8)$ & $0.0799(11)$ & $0.0728(11)$ & $-0.0033(7)$ & $-0.0008(7)$ & $-0.0403(9)$ \\
\hline $\mathrm{C} 24$ & $0.0452(7)$ & $0.0626(8)$ & $0.0514(8)$ & $-0.0116(6)$ & $-0.0077(6)$ & $-0.0238(7)$ \\
\hline $\mathrm{C} 25$ & $0.0412(7)$ & $0.0605(8)$ & $0.0553(8)$ & $-0.0120(6)$ & $-0.0053(6)$ & $-0.0261(7)$ \\
\hline $\mathrm{C} 26$ & $0.0370(6)$ & $0.0511(7)$ & $0.0550(8)$ & $-0.0065(5)$ & $-0.0015(5)$ & $-0.0259(6)$ \\
\hline $\mathrm{C} 27$ & $0.0393(7)$ & $0.0533(8)$ & $0.0597(8)$ & $-0.0076(6)$ & $-0.0050(6)$ & $-0.0268(7)$ \\
\hline $\mathrm{C} 28$ & $0.0507(8)$ & $0.0632(9)$ & $0.0612(9)$ & $-0.0041(7)$ & $-0.0113(7)$ & $-0.0285(8)$ \\
\hline $\mathrm{C} 29$ & $0.0717(10)$ & $0.0629(9)$ & $0.0559(9)$ & $-0.0118(8)$ & $-0.0085(7)$ & $-0.0173(8)$ \\
\hline $\mathrm{C} 30$ & $0.0667(10)$ & $0.0600(9)$ & $0.0637(10)$ & $-0.0212(8)$ & $-0.0015(7)$ & $-0.0205(8)$ \\
\hline $\mathrm{C} 31$ & $0.0451(7)$ & $0.0556(8)$ & $0.0615(9)$ & $-0.0124(6)$ & $-0.0015(6)$ & $-0.0279(7)$ \\
\hline $\mathrm{C} 32$ & $0.0517(8)$ & $0.0719(10)$ & $0.0592(9)$ & $-0.0199(7)$ & $-0.0093(7)$ & $-0.0264(8)$ \\
\hline C33 & $0.0415(8)$ & $0.1008(14)$ & $0.0788(12)$ & $0.0007(8)$ & $-0.0161(8)$ & $-0.0393(12)$ \\
\hline $\mathrm{C} 34$ & $0.0788(13)$ & $0.0926(14)$ & $0.0750(12)$ & $-0.0343(10)$ & $-0.0343(10)$ & $-0.0076(11)$ \\
\hline N1 & $0.0446(6)$ & $0.0569(7)$ & $0.0529(7)$ & $-0.0122(5)$ & $-0.0037(5)$ & $-0.0189(6)$ \\
\hline $\mathrm{N} 2$ & $0.0433(6)$ & $0.0556(7)$ & $0.0527(7)$ & $-0.0142(5)$ & $-0.0052(5)$ & $-0.0170(5)$ \\
\hline N3 & $0.0479(6)$ & $0.0619(7)$ & $0.0532(7)$ & $-0.0043(5)$ & $-0.0122(5)$ & $-0.0211(6)$ \\
\hline N4 & $0.0417(6)$ & $0.0623(7)$ & $0.0527(7)$ & $-0.0022(5)$ & $-0.0094(5)$ & $-0.0253(6)$ \\
\hline N5 & $0.0636(8)$ & $0.0916(10)$ & $0.0592(8)$ & $-0.0122(7)$ & $0.0065(7)$ & $-0.0386(8)$ \\
\hline N6 & $0.0556(7)$ & $0.0690(8)$ & $0.0689(8)$ & $-0.0282(6)$ & $-0.0055(6)$ & $-0.0271(7)$ \\
\hline
\end{tabular}

Geometric parameters $(\AA, \circ)$

\begin{tabular}{llll}
\hline $\mathrm{C} 1-\mathrm{N} 1$ & $1.2858(17)$ & $\mathrm{C} 19-\mathrm{H} 19$ & 0.9300 \\
$\mathrm{C} 1-\mathrm{C} 2$ & $1.4805(19)$ & $\mathrm{C} 20-\mathrm{C} 21$ & $1.369(3)$ \\
$\mathrm{C} 1-\mathrm{C} 8$ & $1.5078(19)$ & $\mathrm{C} 20-\mathrm{H} 20$ & 0.9300 \\
$\mathrm{C} 2-\mathrm{C} 7$ & $1.386(2)$ & $\mathrm{C} 21-\mathrm{C} 22$ & $1.390(2)$ \\
$\mathrm{C} 2-\mathrm{C} 3$ & $1.390(2)$ & $\mathrm{C} 21-\mathrm{H} 21$ & 0.9300 \\
$\mathrm{C} 3-\mathrm{C} 4$ & $1.379(2)$ & $\mathrm{C} 22-\mathrm{N} 5$ & $1.375(2)$
\end{tabular}




\begin{tabular}{|c|c|c|c|}
\hline $\mathrm{C} 3-\mathrm{H} 2$ & 0.9300 & $\mathrm{C} 23-\mathrm{N} 5$ & $1.350(2)$ \\
\hline $\mathrm{C} 4-\mathrm{C} 5$ & $1.365(3)$ & $\mathrm{C} 23-\mathrm{H} 23$ & 0.9300 \\
\hline $\mathrm{C} 4-\mathrm{H} 3$ & 0.9300 & $\mathrm{C} 24-\mathrm{N} 2$ & $1.2913(17)$ \\
\hline $\mathrm{C} 5-\mathrm{C} 6$ & $1.372(3)$ & $\mathrm{C} 24-\mathrm{C} 25$ & $1.454(2)$ \\
\hline $\mathrm{C} 5-\mathrm{H} 4$ & 0.9300 & $\mathrm{C} 24-\mathrm{C} 34$ & $1.499(2)$ \\
\hline $\mathrm{C} 6-\mathrm{C} 7$ & $1.394(2)$ & $\mathrm{C} 25-\mathrm{C} 32$ & $1.3777(19)$ \\
\hline $\mathrm{C} 6-\mathrm{H} 5$ & 0.9300 & $\mathrm{C} 25-\mathrm{C} 26$ & $1.439(2)$ \\
\hline $\mathrm{C} 7-\mathrm{H} 6$ & 0.9300 & $\mathrm{C} 26-\mathrm{C} 27$ & $1.4042(19)$ \\
\hline $\mathrm{C} 8-\mathrm{N} 3$ & $1.2832(18)$ & $\mathrm{C} 26-\mathrm{C} 31$ & $1.4116(19)$ \\
\hline $\mathrm{C} 8-\mathrm{C} 9$ & $1.4771(19)$ & $\mathrm{C} 27-\mathrm{C} 28$ & $1.372(2)$ \\
\hline $\mathrm{C} 9-\mathrm{C} 10$ & $1.389(2)$ & $\mathrm{C} 27-\mathrm{H} 27$ & 0.9300 \\
\hline $\mathrm{C} 9-\mathrm{C} 14$ & $1.391(2)$ & $\mathrm{C} 28-\mathrm{C} 29$ & $1.398(2)$ \\
\hline $\mathrm{C} 10-\mathrm{C} 11$ & $1.387(2)$ & $\mathrm{C} 28-\mathrm{H} 28$ & 0.9300 \\
\hline $\mathrm{C} 10-\mathrm{H} 7$ & 0.9300 & $\mathrm{C} 29-\mathrm{C} 30$ & $1.373(2)$ \\
\hline $\mathrm{C} 11-\mathrm{C} 12$ & $1.371(3)$ & $\mathrm{C} 29-\mathrm{H} 29$ & 0.9300 \\
\hline $\mathrm{C} 11-\mathrm{H} 10$ & 0.9300 & $\mathrm{C} 30-\mathrm{C} 31$ & $1.386(2)$ \\
\hline $\mathrm{C} 12-\mathrm{C} 13$ & $1.372(4)$ & $\mathrm{C} 30-\mathrm{H} 30$ & 0.9300 \\
\hline $\mathrm{C} 12-\mathrm{H} 12$ & 0.9300 & $\mathrm{C} 31-\mathrm{N} 6$ & $1.3819(19)$ \\
\hline $\mathrm{C} 13-\mathrm{C} 14$ & $1.383(3)$ & $\mathrm{C} 32-\mathrm{N} 6$ & $1.355(2)$ \\
\hline C13-H13 & 0.9300 & $\mathrm{C} 32-\mathrm{H} 32$ & 0.9300 \\
\hline $\mathrm{C} 14-\mathrm{H} 11$ & 0.9300 & $\mathrm{C} 33-\mathrm{H} 33 \mathrm{~A}$ & 0.9600 \\
\hline $\mathrm{C} 15-\mathrm{N} 4$ & $1.2959(17)$ & $\mathrm{C} 33-\mathrm{H} 33 \mathrm{~B}$ & 0.9600 \\
\hline $\mathrm{C} 15-\mathrm{C} 16$ & $1.447(2)$ & $\mathrm{C} 33-\mathrm{H} 33 \mathrm{C}$ & 0.9600 \\
\hline $\mathrm{C} 15-\mathrm{C} 33$ & $1.5004(19)$ & $\mathrm{C} 34-\mathrm{H} 34 \mathrm{~A}$ & 0.9600 \\
\hline $\mathrm{C} 16-\mathrm{C} 23$ & $1.376(2)$ & $\mathrm{C} 34-\mathrm{H} 34 \mathrm{~B}$ & 0.9600 \\
\hline $\mathrm{C} 16-\mathrm{C} 17$ & $1.4489(19)$ & $\mathrm{C} 34-\mathrm{H} 34 \mathrm{C}$ & 0.9600 \\
\hline $\mathrm{C} 17-\mathrm{C} 18$ & $1.397(2)$ & $\mathrm{N} 1-\mathrm{N} 2$ & $1.3995(16)$ \\
\hline $\mathrm{C} 17-\mathrm{C} 22$ & $1.410(2)$ & $\mathrm{N} 3-\mathrm{N} 4$ & $1.4055(16)$ \\
\hline $\mathrm{C} 18-\mathrm{C} 19$ & $1.374(2)$ & N5-H35 & 0.8600 \\
\hline $\mathrm{C} 18-\mathrm{H} 18$ & 0.9300 & N6-H36 & 0.8600 \\
\hline $\mathrm{C} 19-\mathrm{C} 20$ & $1.399(3)$ & & \\
\hline $\mathrm{N} 1-\mathrm{C} 1-\mathrm{C} 2$ & $118.19(12)$ & $\mathrm{C} 19-\mathrm{C} 20-\mathrm{H} 20$ & 119.5 \\
\hline $\mathrm{N} 1-\mathrm{C} 1-\mathrm{C} 8$ & $122.27(12)$ & $\mathrm{C} 20-\mathrm{C} 21-\mathrm{C} 22$ & $117.52(17)$ \\
\hline $\mathrm{C} 2-\mathrm{C} 1-\mathrm{C} 8$ & $119.51(11)$ & $\mathrm{C} 20-\mathrm{C} 21-\mathrm{H} 21$ & 121.2 \\
\hline $\mathrm{C} 7-\mathrm{C} 2-\mathrm{C} 3$ & $118.12(14)$ & $\mathrm{C} 22-\mathrm{C} 21-\mathrm{H} 21$ & 121.2 \\
\hline $\mathrm{C} 7-\mathrm{C} 2-\mathrm{C} 1$ & $121.02(13)$ & $\mathrm{N} 5-\mathrm{C} 22-\mathrm{C} 21$ & $129.92(16)$ \\
\hline $\mathrm{C} 3-\mathrm{C} 2-\mathrm{C} 1$ & $120.80(13)$ & $\mathrm{N} 5-\mathrm{C} 22-\mathrm{C} 17$ & $107.44(14)$ \\
\hline $\mathrm{C} 4-\mathrm{C} 3-\mathrm{C} 2$ & $121.09(16)$ & $\mathrm{C} 21-\mathrm{C} 22-\mathrm{C} 17$ & $122.61(15)$ \\
\hline $\mathrm{C} 4-\mathrm{C} 3-\mathrm{H} 2$ & 119.5 & $\mathrm{~N} 5-\mathrm{C} 23-\mathrm{C} 16$ & $110.58(14)$ \\
\hline $\mathrm{C} 2-\mathrm{C} 3-\mathrm{H} 2$ & 119.5 & $\mathrm{~N} 5-\mathrm{C} 23-\mathrm{H} 23$ & 124.7 \\
\hline $\mathrm{C} 5-\mathrm{C} 4-\mathrm{C} 3$ & $120.37(17)$ & $\mathrm{C} 16-\mathrm{C} 23-\mathrm{H} 23$ & 124.7 \\
\hline $\mathrm{C} 5-\mathrm{C} 4-\mathrm{H} 3$ & 119.8 & $\mathrm{~N} 2-\mathrm{C} 24-\mathrm{C} 25$ & $116.86(13)$ \\
\hline $\mathrm{C} 3-\mathrm{C} 4-\mathrm{H} 3$ & 119.8 & $\mathrm{~N} 2-\mathrm{C} 24-\mathrm{C} 34$ & $123.95(14)$ \\
\hline $\mathrm{C} 4-\mathrm{C} 5-\mathrm{C} 6$ & $119.76(16)$ & $\mathrm{C} 25-\mathrm{C} 24-\mathrm{C} 34$ & $119.18(13)$ \\
\hline $\mathrm{C} 4-\mathrm{C} 5-\mathrm{H} 4$ & 120.1 & $\mathrm{C} 32-\mathrm{C} 25-\mathrm{C} 26$ & $105.77(13)$ \\
\hline $\mathrm{C} 6-\mathrm{C} 5-\mathrm{H} 4$ & 120.1 & $\mathrm{C} 32-\mathrm{C} 25-\mathrm{C} 24$ & $126.47(14)$ \\
\hline $\mathrm{C} 5-\mathrm{C} 6-\mathrm{C} 7$ & $120.38(16)$ & $\mathrm{C} 26-\mathrm{C} 25-\mathrm{C} 24$ & $127.68(12)$ \\
\hline
\end{tabular}




$\begin{array}{ll}\text { C5-C6-H5 } & 119.8 \\ \text { C7-C6-H5 } & 119.8 \\ \text { C2-C7-C6 } & 120.25(16) \\ \text { C2-C7-H6 } & 119.9 \\ \text { C6-C7-H6 } & 119.9 \\ \text { N3-C8-C9 } & 118.99(13) \\ \text { N3-C8-C1 } & 122.12(12) \\ \text { C9-C8-C1 } & 118.80(12) \\ \text { C10-C9-C14 } & 118.74(16) \\ \text { C10-C9-C } & 120.44(14) \\ \text { C14-C9-C8 } & 120.81(15) \\ \text { C11-C10-C } & 120.5(2) \\ \text { C11-C10-H7 } & 119.8 \\ \text { C9-C10-H7 } & 119.8 \\ \text { C12-C11-C10 } & 120.2(2) \\ \text { C12-C11-H10 } & 119.9 \\ \text { C10-C11-H10 } & 119.9 \\ \text { C11-C12-C13 } & 119.71(19) \\ \text { C11-C12-H12 } & 120.1 \\ \text { C13-C12-H12 } & 120.1 \\ \text { C12-C13-C14 } & 120.9(2) \\ \text { C12-C13-H13 } & 119.6 \\ \text { C14-C13-H13 } & 119.6 \\ \text { C13-C14-C9 } & 119.9(2) \\ \text { C13-C14-H11 } & 120.0 \\ \text { C9-C14-H11 } & 120.0 \\ \text { N4-C15-C16 } & 116.92(12) \\ \text { N4-C15-C33 } & 123.90(14) \\ \text { C16-C15-C33 } & 119.11(13) \\ \text { C23-C16-C15 } & 126.10(13) \\ \text { C23-C16-C17 } & 105.66(13) \\ \text { C15-C16-C17 } & 128.03(12) \\ \text { C18-C17-C22 } & 118.36(14) \\ \text { C18-C17-C16 } & 134.83(13) \\ \text { C22-C17-C16 } & 106.73(12) \\ \text { C19-C18-C17 } & 118.92(15) \\ \text { C19-C18-H18 } & 120.5 \\ \text { C17-C18-H18 } & 120.5 \\ \text { C18-C19-C20 } & 121.59(16) \\ \text { C18-C19-H19 } & 119.2 \\ \text { C20-C19-H19 } & 119.2 \\ \text { C21-C20-C19 } & 120.99(16) \\ \text { C21-C20-H20 } & \end{array}$

$118.54(13)$

$134.21(13)$

$107.20(12)$

$118.90(13)$

120.5

120.5

$121.28(15)$

119.4

119.4

$121.37(15)$

119.3

119.3

$117.54(15)$

121.2

121.2

$130.41(14)$

$107.20(13)$

$122.35(14)$

$110.60(13)$

124.7

124.7

109.5

109.5

109.5

109.5

109.5

109.5

109.5

109.5

109.5

109.5

109.5

109.5

$113.49(11)$

$114.33(12)$

$112.87(11)$

$113.57(11)$

$109.58(13)$

125.2

125.2

$109.22(12)$

125.4

125.4

Hydrogen-bond geometry $\left(A,{ }^{\circ}\right)$

\begin{tabular}{lllll}
\hline$D-\mathrm{H} \cdots A$ & $D-\mathrm{H}$ & $\mathrm{H} \cdots A$ & $D \cdots A$ & $D-\mathrm{H} \cdots A$ \\
\hline $\mathrm{N} 6-\mathrm{H} 36 \cdots \mathrm{N} 4^{\mathrm{i}}$ & 0.86 & 2.36 & $3.1675(17)$ & 156
\end{tabular}




\begin{tabular}{lllll}
$\mathrm{C} 14-\mathrm{H} 11 \cdots \mathrm{N} 3$ & 0.93 & 2.52 & $2.815(2)$ & 99 \\
$\mathrm{C} 18-\mathrm{H} 18 \cdots \mathrm{N} 4$ & 0.93 & 2.61 & $3.1003(19)$ & 114 \\
$\mathrm{C} 27-\mathrm{H} 27 \cdots \mathrm{N} 2$ & 0.93 & 2.59 & $3.0859(19)$ & 114 \\
$\mathrm{C} 34-\mathrm{H} 34 C \cdots \mathrm{N} 1$ & 0.96 & 2.29 & $2.712(2)$ & 106 \\
\hline
\end{tabular}

Symmetry code: (i) $-x,-y+1,-z+1$.

(1Z,2Z)-1,2-Bis\{(E)-[(1-methyl-1H-indol-3-yl) \methylidene]hydrazinylidene\}-1,2-diphenylethane acetonitrile hemisolvate (3-BDHMFI)

\section{Crystal data}

$2 \mathrm{C}_{34} \mathrm{H}_{28} \mathrm{~N}_{6} \cdot \mathrm{C}_{2} \mathrm{H}_{3} \mathrm{~N}$

$M_{r}=1082.30$

Triclinic, $P \overline{1}$

$a=11.2710(6) \AA$

$b=11.6944(7) \AA$

$c=12.5164(6) \AA$

$\alpha=79.875(4)^{\circ}$

$\beta=87.701(4)^{\circ}$

$\gamma=64.941(6)^{\circ}$

$V=1470.10(15) \AA^{3}$

\section{Data collection}

Bruker SMART CCD area detector diffractometer

Radiation source: fine-focus sealed tube Detector resolution: 10.13 pixels $\mathrm{mm}^{-1}$ phi and $\omega$ scans

Absorption correction: multi-scan

(SADABS; Bruker, 2000)

$T_{\min }=0.905, T_{\max }=0.943$

\section{Refinement}

Refinement on $F^{2}$

Least-squares matrix: full

$R\left[F^{2}>2 \sigma\left(F^{2}\right)\right]=0.049$

$w R\left(F^{2}\right)=0.151$

$S=1.04$

5640 reflections

424 parameters

2 restraints

Hydrogen site location: mixed

Only H-atom displacement parameters refined

$$
\begin{aligned}
& Z=1 \\
& F(000)=570 \\
& D_{\mathrm{x}}=1.222 \mathrm{Mg} \mathrm{m}^{-3}
\end{aligned}
$$

Mo $K \alpha$ radiation, $\lambda=0.71073 \AA$

Cell parameters from 380 reflections

$\theta=2.5-26.0^{\circ}$

$\mu=0.08 \mathrm{~mm}^{-1}$

$T=293 \mathrm{~K}$

Block, yellow

$0.35 \times 0.20 \times 0.15 \mathrm{~mm}$

13418 measured reflections

5640 independent reflections

4445 reflections with $I>2 \sigma(I)$

$R_{\text {int }}=0.029$

$\theta_{\text {max }}=26.0^{\circ}, \theta_{\text {min }}=2.1^{\circ}$

$h=-13 \rightarrow 13$

$k=-14 \rightarrow 14$

$l=-15 \rightarrow 10$

\section{Special details}

Geometry. All esds (except the esd in the dihedral angle between two 1.s. planes) are estimated using the full covariance matrix. The cell esds are taken into account individually in the estimation of esds in distances, angles and torsion angles; correlations between esds in cell parameters are only used when they are defined by crystal symmetry. An approximate (isotropic) treatment of cell esds is used for estimating esds involving l.s. planes.

Refinement. Refinement of $\mathrm{F}^{2}$ against ALL reflections. The weighted R-factor $\mathrm{wR}$ and goodness of fit $\mathrm{S}$ are based on $\mathrm{F}^{2}$, conventional R-factors $R$ are based on $F$, with $F$ set to zero for negative $F^{2}$. The threshold expression of $F^{2}>2 \operatorname{sigma}\left(F^{2}\right)$ is used only for calculating R-factors(gt) etc. and is not relevant to the choice of reflections for refinement. R-factors based on $\mathrm{F}^{2}$ are statistically about twice as large as those based on F, and R-factors based on ALL data will be even larger. 
Fractional atomic coordinates and isotropic or equivalent isotropic displacement parameters $\left(\AA^{2}\right)$

\begin{tabular}{|c|c|c|c|c|c|}
\hline & $x$ & $y$ & $z$ & $U_{\text {iso }} * / U_{\text {eq }}$ & Occ. $(<1)$ \\
\hline $\mathrm{C} 1$ & $1.02888(14)$ & $0.32026(15)$ & $0.22614(13)$ & $0.0468(4)$ & \\
\hline $\mathrm{C} 2$ & $0.90615(15)$ & $0.33587(15)$ & $0.17364(13)$ & $0.0501(4)$ & \\
\hline $\mathrm{C} 3$ & $0.84410(18)$ & $0.4332(2)$ & $0.08691(16)$ & $0.0645(5)$ & \\
\hline H3 & 0.880544 & 0.489721 & 0.058970 & $0.072(6)^{*}$ & \\
\hline $\mathrm{C} 4$ & $0.7277(2)$ & $0.4466(2)$ & $0.04165(18)$ & $0.0781(6)$ & \\
\hline $\mathrm{H} 4$ & 0.687632 & 0.511274 & -0.017495 & $0.099(8)^{*}$ & \\
\hline $\mathrm{C} 5$ & $0.6708(2)$ & 0.3663 & $0.0825(2)$ & $0.0849(7)$ & \\
\hline H5 & 0.592178 & 0.376884 & 0.051894 & $0.107(9)^{*}$ & \\
\hline C6 & $0.7306(2)$ & 0.2703 & $0.1687(2)$ & $0.0930(8)$ & \\
\hline H6 & 0.692732 & 0.215144 & 0.196816 & $0.116(10)^{*}$ & \\
\hline $\mathrm{C} 7$ & $0.8474(2)$ & $0.2552(2)$ & 0.21409 (19) & $0.0738(6)$ & \\
\hline $\mathrm{H} 7$ & 0.887172 & 0.189680 & 0.272778 & $0.076(6)^{*}$ & \\
\hline $\mathrm{C} 8$ & $1.09142(14)$ & $0.20654(15)$ & $0.31530(13)$ & 0.0461 & \\
\hline C9 & $1.04864(15)$ & $0.22239(16)$ & $0.42683(13)$ & $0.0511(4)$ & \\
\hline $\mathrm{C} 10$ & $0.98055(18)$ & 0.34437 (19) & $0.45203(16)$ & $0.0630(5)$ & \\
\hline H10 & 0.966044 & 0.416152 & 0.399284 & $0.081(7)^{*}$ & \\
\hline C11 & $0.9343(2)$ & $0.3596(2)$ & $0.55484(18)$ & $0.0753(6)$ & \\
\hline H11 & 0.889723 & 0.441633 & 0.570951 & $0.110(9)^{*}$ & \\
\hline $\mathrm{C} 12$ & $0.9535(2)$ & $0.2554(3)$ & $0.63306(18)$ & $0.0829(7)$ & \\
\hline $\mathrm{H} 12$ & 0.921076 & 0.266331 & 0.701841 & $0.095(8)^{*}$ & \\
\hline $\mathrm{C} 13$ & $1.0203(3)$ & $0.1356(3)$ & $0.60969(18)$ & $0.0939(8)$ & \\
\hline H13 & 1.034229 & 0.064590 & 0.663129 & $0.118(10)^{*}$ & \\
\hline $\mathrm{C} 14$ & $1.0679(2)$ & $0.1181(2)$ & $0.50706(17)$ & $0.0777(6)$ & \\
\hline H14 & 1.113059 & 0.035600 & 0.492203 & $0.091(7)^{*}$ & \\
\hline $\mathrm{C} 15$ & $1.28895(16)$ & $-0.00541(16)$ & $0.16524(14)$ & $0.0531(4)$ & \\
\hline H15 & 1.328560 & -0.073073 & 0.222419 & $0.064(5)^{*}$ & \\
\hline $\mathrm{C} 16$ & $1.33243(15)$ & $-0.02026(16)$ & $0.05718(14)$ & $0.0518(4)$ & \\
\hline $\mathrm{C} 17$ & $1.28980(15)$ & $0.07087(16)$ & $-0.04259(14)$ & $0.0515(4)$ & \\
\hline $\mathrm{C} 18$ & $1.19676(17)$ & $0.19828(18)$ & $-0.07107(16)$ & $0.0614(5)$ & \\
\hline H18 & 1.143422 & 0.241346 & -0.019130 & $0.052(5)^{*}$ & \\
\hline C19 & $1.1861(2)$ & $0.2582(2)$ & $-0.17750(19)$ & $0.0774(6)$ & \\
\hline H19 & 1.125306 & 0.343031 & -0.196933 & $0.097(8)^{*}$ & \\
\hline $\mathrm{C} 20$ & $1.2642(2)$ & $0.1949(2)$ & $-0.25722(19)$ & $0.0811(6)$ & \\
\hline $\mathrm{H} 20$ & 1.254078 & 0.238143 & -0.328465 & $0.086(7)^{*}$ & \\
\hline $\mathrm{C} 21$ & $1.3557(2)$ & $0.0698(2)$ & $-0.23207(17)$ & $0.0701(5)$ & \\
\hline $\mathrm{H} 21$ & 1.407365 & 0.027264 & -0.284991 & $0.078(6)^{*}$ & \\
\hline $\mathrm{C} 22$ & $1.36791(16)$ & $0.00935(17)$ & $-0.12438(14)$ & $0.0542(4)$ & \\
\hline $\mathrm{C} 23$ & $1.43327(17)$ & $-0.12886(17)$ & $0.03118(15)$ & $0.0577(4)$ & \\
\hline $\mathrm{H} 23$ & 1.480119 & -0.202937 & 0.080814 & $0.062(5)^{*}$ & \\
\hline $\mathrm{C} 24$ & $1.22609(15)$ & $0.46706(16)$ & $0.23777(13)$ & $0.0498(4)$ & \\
\hline $\mathrm{H} 24$ & 1.177296 & 0.540514 & 0.188221 & $0.052(5)^{*}$ & \\
\hline $\mathrm{C} 25$ & $1.34296(15)$ & $0.45677(15)$ & $0.28885(13)$ & $0.0493(4)$ & \\
\hline $\mathrm{C} 26$ & $1.43056(16)$ & $0.35601(16)$ & $0.37025(13)$ & $0.0516(4)$ & \\
\hline $\mathrm{C} 27$ & $1.4353(2)$ & $0.23960(18)$ & $0.42710(16)$ & $0.0646(5)$ & \\
\hline $\mathrm{H} 27$ & 1.369824 & 0.213841 & 0.416084 & $0.060(5)^{*}$ & \\
\hline
\end{tabular}




$\begin{array}{lll}\text { C28 } & 1.5388(2) & 0.1642(2) \\ \mathrm{H} 28 & 1.543129 & 0.086425 \\ \mathrm{C} 29 & 1.6376(2) & 0.2015(2) \\ \mathrm{H} 29 & 1.706043 & 0.148178 \\ \mathrm{C} 30 & 1.63570(19) & 0.3150(2) \\ \mathrm{H} 30 & 1.701242 & 0.340156 \\ \mathrm{C} 31 & 1.53133(16) & 0.39131(17) \\ \mathrm{C} 32 & 1.39468(16) & 0.54558(17) \\ \mathrm{H} 32 & 1.357655 & 0.621279 \\ \mathrm{C} 33 & 1.55867(19) & -0.2047(2) \\ \mathrm{H} 33 \mathrm{~A} & 1.632691 & -0.254020 \\ \mathrm{H} 33 \mathrm{~B} & 1.584307 & -0.159587 \\ \mathrm{H} 33 \mathrm{C} & 1.527555 & -0.261002 \\ \mathrm{C} 34 & 1.5904(2) & 0.5748(2) \\ \mathrm{H} 34 \mathrm{~A} & 1.608336 & 0.583200 \\ \mathrm{H} 34 \mathrm{~B} & 1.547020 & 0.658432 \\ \mathrm{H} 34 \mathrm{C} & 1.671310 & 0.527112 \\ \mathrm{C} 35 & 1.000000 & 0.000000 \\ \mathrm{C} 36 & 1.0793(6) & -0.1065(6) \\ \mathrm{N} 1 & 1.07253(12) & 0.40608(13) \\ \mathrm{N} 2 & 1.18768(12) & 0.37708(13) \\ \mathrm{N} 3 & 1.17284(13) & 0.09578(13) \\ \mathrm{N} 4 & 1.19636(13) & 0.09946(13) \\ \text { N5 } & 1.45459(13) & -0.11286(14) \\ \text { N6 } & 1.50671(14) & 0.50781(15) \\ \text { N7 } & 1.1399(6) & -0.1952(6) \\ \text { H35A } & 0.948(6) & 0.003(8) \\ \mathrm{H} 35 \mathrm{~B} & 1.025(14) & 0.055(10) \\ & & \end{array}$

$0.49961(18)$
0.537232
$0.51809(18)$
0.567771
$0.46446(16)$
0.476842
$0.39055(14)$
$0.26514(15)$
0.214953
$-0.13077(19)$
-0.081217
-0.192192
-0.154903
$0.3191(2)$
0.390918
0.275475
0.286992
0.000000
$0.0557(5)$
$0.19845(11)$
$0.25908(11)$
$0.29627(11)$
$0.18477(11)$
$-0.07613(12)$
$0.32476(12)$
$0.1118(5)$
$0.059(4)$
$0.029(13)$
$0.0786(6)$
$0.087(7)^{*}$
$0.0779(6)$
$0.094(7)^{*}$
$0.0698(5)$
$0.068(6)^{*}$
$0.0555(4)$
$0.0552(4)$
$0.068(6)^{*}$
$0.0711(6)$
$0.161(14)^{*}$
$0.148(12)^{*}$
$0.097(8)^{*}$
0.0755 (6)
$0.137(12)^{*}$
$0.135(12)^{*}$
$0.125(10)^{*}$
$0.173(3)$
$0.0879(13)$
0.0508 (3)
$0.0518(3)$
0.0507 (3)
$0.0526(3)$
0.0575 (4)
0.0584 (4)
$0.1225(18)$
$0.25(3)^{*}$
$0.26(6)^{*}$

0.5

0.5

0.5

Atomic displacement parameters $\left(\AA^{2}\right)$

\begin{tabular}{lllllll}
\hline & $U^{11}$ & $U^{22}$ & $U^{33}$ & $U^{12}$ & $U^{13}$ & $U^{23}$ \\
\hline C1 & $0.0396(7)$ & $0.0456(8)$ & $0.0531(8)$ & $-0.0121(6)$ & $0.0104(6)$ & $-0.0208(7)$ \\
C2 & $0.0426(8)$ & $0.0491(8)$ & $0.0564(9)$ & $-0.0143(7)$ & $0.0062(6)$ & $-0.0179(7)$ \\
C3 & $0.0576(10)$ & $0.0676(11)$ & $0.0639(11)$ & $-0.0239(9)$ & $0.0023(8)$ & $-0.0074(9)$ \\
C4 & $0.0607(11)$ & $0.0894(15)$ & $0.0692(13)$ & $-0.0193(11)$ & $-0.0102(10)$ & $-0.0063(11)$ \\
C5 & $0.0580(11)$ & $0.1048(18)$ & $0.0918(16)$ & $-0.0351(12)$ & $-0.0151(11)$ & $-0.0115(13)$ \\
C6 & $0.0724(13)$ & $0.1002(18)$ & $0.116(2)$ & $-0.0521(14)$ & $-0.0175(13)$ & $0.0022(15)$ \\
C7 & $0.0634(11)$ & $0.0706(12)$ & $0.0878(14)$ & $-0.0331(10)$ & $-0.0137(10)$ & $0.0010(11)$ \\
C8 & $0.0385(7)$ & $0.0481(8)$ & $0.0530(9)$ & $-0.0163(6)$ & $0.0068(6)$ & $-0.0180(7)$ \\
C9 & $0.0420(7)$ & $0.0575(9)$ & $0.0539(9)$ & $-0.0176(7)$ & $0.0071(6)$ & $-0.0205(7)$ \\
C10 & $0.0605(10)$ & $0.0645(11)$ & $0.0661(11)$ & $-0.0225(9)$ & $0.0168(8)$ & $-0.0298(9)$ \\
C11 & $0.0735(12)$ & $0.0859(15)$ & $0.0723(13)$ & $-0.0295(11)$ & $0.0224(10)$ & $-0.0440(12)$ \\
C12 & $0.0815(14)$ & $0.1096(18)$ & $0.0604(12)$ & $-0.0359(13)$ & $0.0220(10)$ & $-0.0384(13)$ \\
C13 & $0.118(2)$ & $0.0915(17)$ & $0.0575(12)$ & $-0.0331(15)$ & $0.0197(12)$ & $-0.0110(12)$ \\
C14 & $0.0913(15)$ & $0.0663(12)$ & $0.0632(12)$ & $-0.0206(11)$ & $0.0185(10)$ & $-0.0182(10)$ \\
C15 & $0.0486(8)$ & $0.0464(8)$ & $0.0613(10)$ & $-0.0142(7)$ & $0.0069(7)$ & $-0.0183(7)$ \\
C16 & $0.0443(8)$ & $0.0489(8)$ & $0.0631(10)$ & $-0.0157(7)$ & $0.0107(7)$ & $-0.0247(7)$
\end{tabular}




$\begin{array}{lllllll}\text { C17 } & 0.0429(7) & 0.0534(9) & 0.0631(10) & -0.0205(7) & 0.0080(7) & -0.0240(8) \\ \text { C18 } & 0.0509(9) & 0.0574(10) & 0.0722(12) & -0.0157(8) & 0.0050(8) & -0.0218(9) \\ \text { C19 } & 0.0696(12) & 0.0657(12) & 0.0843(14) & -0.0173(10) & -0.0061(10) & -0.0092(10) \\ \text { C20 } & 0.0868(15) & 0.0903(16) & 0.0654(13) & -0.0385(13) & -0.0005(11) & -0.0080(11) \\ \text { C21 } & 0.0690(12) & 0.0851(14) & 0.0655(12) & -0.0374(11) & 0.0152(9) & -0.0272(10) \\ \text { C22 } & 0.0470(8) & 0.0598(10) & 0.0638(10) & -0.0251(8) & 0.0112(7) & -0.0263(8) \\ \text { C23 } & 0.0520(9) & 0.0495(9) & 0.0693(11) & -0.0154(7) & 0.0108(8) & -0.0226(8) \\ \text { C24 } & 0.0450(8) & 0.0483(8) & 0.0551(9) & -0.0155(7) & 0.0138(7) & -0.0199(7) \\ \text { C25 } & 0.0476(8) & 0.0492(8) & 0.0536(9) & -0.0198(7) & 0.0135(7) & -0.0201(7) \\ \text { C26 } & 0.0507(8) & 0.0545(9) & 0.0518(9) & -0.0207(7) & 0.0151(7) & -0.0220(7) \\ \text { C27 } & 0.0730(12) & 0.0600(11) & 0.0632(11) & -0.0294(9) & 0.0133(9) & -0.0160(9) \\ \text { C28 } & 0.0930(16) & 0.0637(12) & 0.0678(12) & -0.0256(11) & 0.0102(11) & -0.0049(10) \\ \text { C29 } & 0.0685(12) & 0.0789(14) & 0.0649(12) & -0.0123(11) & 0.0008(10) & -0.0080(10) \\ \text { C30 } & 0.0538(10) & 0.0875(14) & 0.0651(11) & -0.0245(10) & 0.0061(8) & -0.0206(10) \\ \text { C31 } & 0.0505(9) & 0.0621(10) & 0.0537(9) & -0.0208(8) & 0.0134(7) & -0.0206(8) \\ \text { C32 } & 0.0526(9) & 0.0530(9) & 0.0608(10) & -0.0214(7) & 0.0107(7) & -0.0166(8) \\ \text { C33 } & 0.0602(11) & 0.0689(12) & 0.0935(14) & -0.0259(10) & 0.0314(10) & -0.0473(11) \\ \text { C34 } & 0.0682(12) & 0.0879(15) & 0.0898(15) & -0.0486(12) & 0.0146(11) & -0.0260(12) \\ \text { C35 } & 0.101(4) & 0.159(7) & 0.271(12) & -0.075(5) & -0.041(6) & -0.008(7) \\ \text { C36 } & 0.073(3) & 0.098(4) & 0.101(4) & -0.045(3) & 0.006(3) & -0.015(3) \\ \text { N1 } & 0.0423(6) & 0.0490(7) & 0.0604(8) & -0.0161(6) & 0.0079(6) & -0.0178(6) \\ \text { N2 } & 0.0425(7) & 0.0513(8) & 0.0625(8) & -0.0180(6) & 0.0083(6) & -0.0185(6) \\ \text { N3 } & 0.0487(7) & 0.0484(7) & 0.0506(7) & -0.0139(6) & 0.0088(6) & -0.0168(6) \\ \text { N4 } & 0.0497(7) & 0.0493(7) & 0.0533(8) & -0.0124(6) & 0.0103(6) & -0.0195(6) \\ \text { N5 } & 0.0499(7) & 0.0563(8) & 0.0704(9) & -0.0196(7) & 0.0190(6) & -0.0329(7) \\ \text { N6 } & 0.0529(8) & 0.0640(9) & 0.0666(9) & -0.0302(7) & 0.0104(6) & -0.0195(7) \\ \text { N7 } & 0.123(4) & 0.127(4) & 0.113(4) & -0.058(4) & 0.005(3) & 0.003(3) \\ & & & & & & \end{array}$

Geometric parameters $\left(\AA,^{\circ}\right)$

\begin{tabular}{llll}
\hline $\mathrm{C} 1-\mathrm{N} 1$ & $1.285(2)$ & $\mathrm{C} 21-\mathrm{C} 22$ & $1.390(3)$ \\
$\mathrm{C} 1-\mathrm{C} 2$ & $1.482(2)$ & $\mathrm{C} 21-\mathrm{H} 21$ & 0.9300 \\
$\mathrm{C} 1-\mathrm{C} 8$ & $1.503(2)$ & $\mathrm{C} 22-\mathrm{N} 5$ & $1.387(2)$ \\
$\mathrm{C} 2-\mathrm{C} 3$ & $1.384(3)$ & $\mathrm{C} 23-\mathrm{N} 5$ & $1.349(2)$ \\
$\mathrm{C} 2-\mathrm{C} 7$ & $1.385(3)$ & $\mathrm{C} 23-\mathrm{H} 23$ & 0.9300 \\
$\mathrm{C} 3-\mathrm{C} 4$ & $1.386(3)$ & $\mathrm{C} 24-\mathrm{N} 2$ & $1.282(2)$ \\
$\mathrm{C} 3-\mathrm{H} 3$ & 0.9300 & $\mathrm{C} 24-\mathrm{C} 25$ & $1.437(2)$ \\
$\mathrm{C} 4-\mathrm{C} 5$ & $1.367(3)$ & $\mathrm{C} 24-\mathrm{H} 24$ & 0.9300 \\
$\mathrm{C} 4-\mathrm{H} 4$ & 0.9300 & $\mathrm{C} 25-\mathrm{C} 32$ & $1.377(2)$ \\
$\mathrm{C} 5-\mathrm{C} 6$ & $1.368(3)$ & $\mathrm{C} 25-\mathrm{C} 26$ & $1.440(2)$ \\
$\mathrm{C} 5-\mathrm{H} 5$ & 0.9300 & $\mathrm{C} 26-\mathrm{C} 27$ & $1.401(3)$ \\
$\mathrm{C} 6-\mathrm{C} 7$ & $1.383(3)$ & $\mathrm{C} 26-\mathrm{C} 31$ & $1.408(2)$ \\
$\mathrm{C} 6-\mathrm{H} 6$ & 0.9300 & $\mathrm{C} 27-\mathrm{C} 28$ & 0.9300 \\
$\mathrm{C} 7-\mathrm{H} 7$ & 0.9300 & $\mathrm{C} 27-\mathrm{H} 27$ & $1.397(3)$ \\
$\mathrm{C} 8-\mathrm{N} 3$ & $1.289(2)$ & $\mathrm{C} 28-\mathrm{C} 29$ & 0.9300 \\
$\mathrm{C} 8-\mathrm{C} 9$ & $1.475(2)$ & $\mathrm{C} 28-\mathrm{H} 28$ & $1.371(3)$ \\
$\mathrm{C} 9-\mathrm{C} 14$ & $1.380(3)$ & $\mathrm{C} 29-\mathrm{C} 30$ & 0.9300 \\
$\mathrm{C} 9-\mathrm{C} 10$ & $1.391(2)$ & $\mathrm{C} 29-\mathrm{H} 29$ &
\end{tabular}




\begin{tabular}{|c|c|c|c|}
\hline $\mathrm{C} 10-\mathrm{C} 11$ & $1.381(3)$ & $\mathrm{C} 30-\mathrm{C} 31$ & $1.394(3)$ \\
\hline $\mathrm{C} 10-\mathrm{H} 10$ & 0.9300 & $\mathrm{C} 30-\mathrm{H} 30$ & 0.9300 \\
\hline $\mathrm{C} 11-\mathrm{C} 12$ & $1.365(3)$ & $\mathrm{C} 31-\mathrm{N} 6$ & $1.384(2)$ \\
\hline $\mathrm{C} 11-\mathrm{H} 11$ & 0.9300 & $\mathrm{C} 32-\mathrm{N} 6$ & $1.354(2)$ \\
\hline $\mathrm{C} 12-\mathrm{C} 13$ & $1.359(3)$ & $\mathrm{C} 32-\mathrm{H} 32$ & 0.9300 \\
\hline $\mathrm{C} 12-\mathrm{H} 12$ & 0.9300 & $\mathrm{C} 33-\mathrm{N} 5$ & $1.457(2)$ \\
\hline $\mathrm{C} 13-\mathrm{C} 14$ & $1.387(3)$ & $\mathrm{C} 33-\mathrm{H} 33 \mathrm{~A}$ & 0.9600 \\
\hline $\mathrm{C} 13-\mathrm{H} 13$ & 0.9300 & $\mathrm{C} 33-\mathrm{H} 33 \mathrm{~B}$ & 0.9600 \\
\hline $\mathrm{C} 14-\mathrm{H} 14$ & 0.9300 & $\mathrm{C} 33-\mathrm{H} 33 \mathrm{C}$ & 0.9600 \\
\hline $\mathrm{C} 15-\mathrm{N} 4$ & $1.286(2)$ & $\mathrm{C} 34-\mathrm{N} 6$ & $1.453(2)$ \\
\hline $\mathrm{C} 15-\mathrm{C} 16$ & $1.434(2)$ & $\mathrm{C} 34-\mathrm{H} 34 \mathrm{~A}$ & 0.9600 \\
\hline C15-H15 & 0.9300 & C34-H34B & 0.9600 \\
\hline $\mathrm{C} 16-\mathrm{C} 23$ & $1.380(2)$ & $\mathrm{C} 34-\mathrm{H} 34 \mathrm{C}$ & 0.9600 \\
\hline $\mathrm{C} 16-\mathrm{C} 17$ & $1.440(3)$ & $\mathrm{C} 35-\mathrm{C} 36^{\mathrm{i}}$ & $1.280(7)$ \\
\hline $\mathrm{C} 17-\mathrm{C} 18$ & $1.402(2)$ & $\mathrm{C} 35-\mathrm{C} 36$ & $1.280(7)$ \\
\hline $\mathrm{C} 17-\mathrm{C} 22$ & $1.411(2)$ & $\mathrm{C} 35-\mathrm{H} 35 \mathrm{~A}$ & $0.92(2)$ \\
\hline $\mathrm{C} 18-\mathrm{C} 19$ & $1.376(3)$ & $\mathrm{C} 35-\mathrm{H} 35 \mathrm{~B}$ & $0.93(2)$ \\
\hline C18-H18 & 0.9300 & $\mathrm{C} 35-\mathrm{H} 35 \mathrm{~A}^{\mathrm{i}}$ & $0.92(2)$ \\
\hline $\mathrm{C} 19-\mathrm{C} 20$ & $1.399(3)$ & $\mathrm{C} 35-\mathrm{H} 35 \mathrm{~B}^{\mathrm{i}}$ & $0.93(2)$ \\
\hline C19-H19 & 0.9300 & $\mathrm{C} 36-\mathrm{N} 7$ & $1.104(7)$ \\
\hline $\mathrm{C} 20-\mathrm{C} 21$ & $1.374(3)$ & $\mathrm{N} 1-\mathrm{N} 2$ & $1.4110(19)$ \\
\hline $\mathrm{C} 20-\mathrm{H} 20$ & 0.9300 & $\mathrm{~N} 3-\mathrm{N} 4$ & 1.4067 (19) \\
\hline $\mathrm{N} 1-\mathrm{C} 1-\mathrm{C} 2$ & $119.59(15)$ & $\mathrm{N} 5-\mathrm{C} 23-\mathrm{H} 23$ & 124.6 \\
\hline $\mathrm{N} 1-\mathrm{C} 1-\mathrm{C} 8$ & $123.36(14)$ & $\mathrm{C} 16-\mathrm{C} 23-\mathrm{H} 23$ & 124.6 \\
\hline $\mathrm{C} 2-\mathrm{C} 1-\mathrm{C} 8$ & $116.93(14)$ & $\mathrm{N} 2-\mathrm{C} 24-\mathrm{C} 25$ & $121.38(16)$ \\
\hline $\mathrm{C} 3-\mathrm{C} 2-\mathrm{C} 7$ & $118.14(16)$ & $\mathrm{N} 2-\mathrm{C} 24-\mathrm{H} 24$ & 119.3 \\
\hline $\mathrm{C} 3-\mathrm{C} 2-\mathrm{C} 1$ & $121.77(16)$ & $\mathrm{C} 25-\mathrm{C} 24-\mathrm{H} 24$ & 119.3 \\
\hline $\mathrm{C} 7-\mathrm{C} 2-\mathrm{C} 1$ & $120.03(16)$ & $\mathrm{C} 32-\mathrm{C} 25-\mathrm{C} 24$ & $124.65(16)$ \\
\hline $\mathrm{C} 2-\mathrm{C} 3-\mathrm{C} 4$ & $120.1(2)$ & $\mathrm{C} 32-\mathrm{C} 25-\mathrm{C} 26$ & $106.03(15)$ \\
\hline $\mathrm{C} 2-\mathrm{C} 3-\mathrm{H} 3$ & 120.0 & $\mathrm{C} 24-\mathrm{C} 25-\mathrm{C} 26$ & $129.31(15)$ \\
\hline $\mathrm{C} 4-\mathrm{C} 3-\mathrm{H} 3$ & 120.0 & $\mathrm{C} 27-\mathrm{C} 26-\mathrm{C} 31$ & $118.55(17)$ \\
\hline $\mathrm{C} 5-\mathrm{C} 4-\mathrm{C} 3$ & $121.1(2)$ & $\mathrm{C} 27-\mathrm{C} 26-\mathrm{C} 25$ & $134.91(17)$ \\
\hline $\mathrm{C} 5-\mathrm{C} 4-\mathrm{H} 4$ & 119.4 & $\mathrm{C} 31-\mathrm{C} 26-\mathrm{C} 25$ & $106.54(15)$ \\
\hline $\mathrm{C} 3-\mathrm{C} 4-\mathrm{H} 4$ & 119.4 & $\mathrm{C} 28-\mathrm{C} 27-\mathrm{C} 26$ & $118.6(2)$ \\
\hline $\mathrm{C} 4-\mathrm{C} 5-\mathrm{C} 6$ & $119.4(2)$ & $\mathrm{C} 28-\mathrm{C} 27-\mathrm{H} 27$ & 120.7 \\
\hline $\mathrm{C} 4-\mathrm{C} 5-\mathrm{H} 5$ & 120.3 & $\mathrm{C} 26-\mathrm{C} 27-\mathrm{H} 27$ & 120.7 \\
\hline $\mathrm{C} 6-\mathrm{C} 5-\mathrm{H} 5$ & 120.3 & $\mathrm{C} 27-\mathrm{C} 28-\mathrm{C} 29$ & $121.7(2)$ \\
\hline $\mathrm{C} 5-\mathrm{C} 6-\mathrm{C} 7$ & $120.1(2)$ & $\mathrm{C} 27-\mathrm{C} 28-\mathrm{H} 28$ & 119.2 \\
\hline $\mathrm{C} 5-\mathrm{C} 6-\mathrm{H} 6$ & 119.9 & $\mathrm{C} 29-\mathrm{C} 28-\mathrm{H} 28$ & 119.2 \\
\hline $\mathrm{C} 7-\mathrm{C} 6-\mathrm{H} 6$ & 119.9 & $\mathrm{C} 30-\mathrm{C} 29-\mathrm{C} 28$ & $121.3(2)$ \\
\hline $\mathrm{C} 6-\mathrm{C} 7-\mathrm{C} 2$ & $121.1(2)$ & $\mathrm{C} 30-\mathrm{C} 29-\mathrm{H} 29$ & 119.3 \\
\hline $\mathrm{C} 6-\mathrm{C} 7-\mathrm{H} 7$ & 119.4 & $\mathrm{C} 28-\mathrm{C} 29-\mathrm{H} 29$ & 119.3 \\
\hline $\mathrm{C} 2-\mathrm{C} 7-\mathrm{H} 7$ & 119.4 & $\mathrm{C} 29-\mathrm{C} 30-\mathrm{C} 31$ & $117.2(2)$ \\
\hline $\mathrm{N} 3-\mathrm{C} 8-\mathrm{C} 9$ & $119.91(15)$ & $\mathrm{C} 29-\mathrm{C} 30-\mathrm{H} 30$ & 121.4 \\
\hline $\mathrm{N} 3-\mathrm{C} 8-\mathrm{C} 1$ & $122.34(14)$ & $\mathrm{C} 31-\mathrm{C} 30-\mathrm{H} 30$ & 121.4 \\
\hline $\mathrm{C} 9-\mathrm{C} 8-\mathrm{C} 1$ & $117.58(13)$ & $\mathrm{N} 6-\mathrm{C} 31-\mathrm{C} 30$ & $129.16(18)$ \\
\hline $\mathrm{C} 14-\mathrm{C} 9-\mathrm{C} 10$ & 118.14 (17) & $\mathrm{N} 6-\mathrm{C} 31-\mathrm{C} 26$ & $108.11(15)$ \\
\hline
\end{tabular}




$\begin{array}{ll}\mathrm{C} 14-\mathrm{C} 9-\mathrm{C} 8 & 121.49(16) \\ \mathrm{C} 10-\mathrm{C} 9-\mathrm{C} 8 & 120.27(17) \\ \mathrm{C} 11-\mathrm{C} 10-\mathrm{C} 9 & 120.5(2) \\ \mathrm{C} 11-\mathrm{C} 10-\mathrm{H} 10 & 119.8 \\ \mathrm{C} 9-\mathrm{C} 10-\mathrm{H} 10 & 119.8 \\ \mathrm{C} 12-\mathrm{C} 11-\mathrm{C} 10 & 120.6(2) \\ \mathrm{C} 12-\mathrm{C} 11-\mathrm{H} 11 & 119.7 \\ \mathrm{C} 10-\mathrm{C} 11-\mathrm{H} 11 & 119.7 \\ \mathrm{C} 13-\mathrm{C} 12-\mathrm{C} 11 & 119.5(2) \\ \mathrm{C} 13-\mathrm{C} 12-\mathrm{H} 12 & 120.2 \\ \mathrm{C} 11-\mathrm{C} 12-\mathrm{H} 12 & 120.2 \\ \mathrm{C} 12-\mathrm{C} 13-\mathrm{C} 14 & 120.8(2) \\ \mathrm{C} 12-\mathrm{C} 13-\mathrm{H} 13 & 119.6 \\ \mathrm{C} 14-\mathrm{C} 13-\mathrm{H} 13 & 119.6 \\ \mathrm{C} 9-\mathrm{C} 14-\mathrm{C} 13 & 120.5(2) \\ \mathrm{C} 9-\mathrm{C} 14-\mathrm{H} 14 & 119.8 \\ \mathrm{C} 13-\mathrm{C} 14-\mathrm{H} 14 & 119.8 \\ \mathrm{~N} 4-\mathrm{C} 15-\mathrm{C} 16 & 121.41(16) \\ \mathrm{N} 4-\mathrm{C} 15-\mathrm{H} 15 & 119.3 \\ \mathrm{C} 16-\mathrm{C} 15-\mathrm{H} 15 & 119.3 \\ \mathrm{C} 23-\mathrm{C} 16-\mathrm{C} 15 & 124.28(17) \\ \mathrm{C} 23-\mathrm{C} 16-\mathrm{C} 17 & 106.21(15) \\ \mathrm{C} 15-\mathrm{C} 16-\mathrm{C} 17 & 129.43(14) \\ \mathrm{C} 18-\mathrm{C} 17-\mathrm{C} 22 & 118.62(17) \\ \mathrm{C} 18-\mathrm{C} 17-\mathrm{C} 16 & 134.93(16) \\ \mathrm{C} 22-\mathrm{C} 17-\mathrm{C} 16 & 106.42(14) \\ \mathrm{C} 19-\mathrm{C} 18-\mathrm{C} 17 & 118.58(18) \\ \mathrm{C} 19-\mathrm{C} 18-\mathrm{H} 18 & 120.7 \\ \mathrm{C} 17-\mathrm{C} 18-\mathrm{H} 18 & 120.7 \\ \mathrm{C} 18-\mathrm{C} 19-\mathrm{C} 20 & 121.7(2) \\ \mathrm{C} 18-\mathrm{C} 19-\mathrm{H} 19 & 119.2 \\ \mathrm{C} 20-\mathrm{C} 19-\mathrm{H} 19 & 119.2 \\ \mathrm{C} 21-\mathrm{C} 20-\mathrm{C} 19 & 121.1(2) \\ \mathrm{C} 21-\mathrm{C} 20-\mathrm{H} 20 & 119.4 \\ \mathrm{C} 19-\mathrm{C} 20-\mathrm{H} 20 & 119.4 \\ \mathrm{C} 20-\mathrm{C} 21-\mathrm{C} 22 & 117.36(19) \\ \mathrm{C} 20-\mathrm{C} 21-\mathrm{H} 21 & 121.3 \\ \mathrm{C} 22-\mathrm{C} 21-\mathrm{H} 21 & 121.3 \\ \mathrm{~N} 5-\mathrm{C} 22-\mathrm{C} 21 & \\ \mathrm{~N} 5-\mathrm{C} 22-\mathrm{C} 17 & \mathrm{C} 21-\mathrm{C} 22-\mathrm{C} 17 \\ \mathrm{~N} 5-\mathrm{C} 23-\mathrm{C} 16 & (16) \\ & \end{array}$

$\begin{array}{ll}\text { C30-C31-C26 } & 122.72(18) \\ \text { N6-C32-C25 } & 110.85(16) \\ \text { N6-C32-H32 } & 124.6 \\ \text { C25-C32-H32 } & 124.6 \\ \text { N5-C33-H33A } & 109.5 \\ \text { N5-C33-H33B } & 109.5 \\ \text { H33A-C33-H33B } & 109.5 \\ \text { N5-C33-H33C } & 109.5 \\ \text { H33A-C33-H33C } & 109.5 \\ \text { H33B-C33-H33C } & 109.5 \\ \text { N6-C34-H34A } & 109.5 \\ \text { N6-C34-H34B } & 109.5 \\ \text { H34A-C34-H34B } & 109.5 \\ \text { N6-C34-H34C } & 109.5 \\ \text { H34A-C34-H34C } & 109.5 \\ \text { H34B-C34-H34C } & 109.5 \\ \text { C36-C35-C36 } & 180.0 \\ \text { C36-C35-H35A } & 96(4) \\ \text { C36-C35-H35A } & 84(4) \\ \text { C36-C35-H35B } & 81(8) \\ \text { C36-C35-H35B } & 99(8) \\ \text { H35A-C35-H35B } & 86(8) \\ \text { C36-C35-H35A } & 84(4) \\ \text { C36-C35-H35A } & 96(4) \\ \text { H35A-C35-H35A } & 180.0 \\ \text { H35B-C35-H35A } & 94(8) \\ \text { C36-C35-H35B } & 99(8) \\ \text { C36-C35-H35B } & 81(8) \\ \text { H35A-C35-H35B } & 94(8) \\ \text { H35B-C35-H35B } & 180(6) \\ \text { H35A-C35-H35B } & 86(8) \\ \text { N7-C36-C35 } & 173.2(7) \\ \text { C1-N1-N2 } & 111.60(14) \\ \text { C24-N2-N1 } & 111.89(14) \\ \text { C8-N3-N4 } & 111.13(13) \\ \text { C15-N4-N3 } & 112.23(14) \\ \text { C23-N5-C22 } & 108.75(13) \\ \text { C23-N5-C33 } & 125.59(17) \\ \text { C22-N5-C33 } & 125.48(17) \\ \text { C32-N6-C31 } & 108.47(15) \\ \text { C32-N6-C34 } & 126.40(17) \\ \text { C31-N6-C34 } & \\ & \end{array}$

Symmetry code: (i) $-x+2,-y,-z$.

Hydrogen-bond geometry $\left(A,{ }^{\circ}\right)$

$D-\mathrm{H} \cdots A \quad D-\mathrm{H} \quad \mathrm{H} \cdots A \quad D \cdots A \quad D-\mathrm{H} \cdots A$




\begin{tabular}{lllll}
\hline $\mathrm{C} 12-\mathrm{H} 12 \cdots \mathrm{N} 7^{\mathrm{ii}}$ & 0.93 & 2.51 & $3.372(6)$ & 155 \\
\hline
\end{tabular}

Symmetry code: (ii) $-x+2,-y,-z+1$.

(1Z,2Z)-1,2-Bis\{(E)-[(naphthalen-1-yl)methylidene]hydrazinylidene\}-1,2-diphenylethane (4-BDHFN)

Crystal data

$$
\begin{aligned}
& \mathrm{C}_{36} \mathrm{H}_{26} \mathrm{~N}_{4} \\
& M_{r}=514.61 \\
& \text { Monoclinic, } C 2 / c \\
& a=26.195(8) \AA \\
& b=9.809(3) \AA \\
& c=11.806(4) \AA \\
& \beta=115.230(5)^{\circ} \\
& V=2744.2(15) \AA^{3} \\
& Z=4
\end{aligned}
$$

\section{Data collection}

Bruker SMART CCD area detector diffractometer

Radiation source: fine-focus sealed tube Detector resolution: 10.22 pixels $\mathrm{mm}^{-1}$ phi and $\omega$ scans

Absorption correction: multi-scan

(SADABS; Bruker, 2000)

$T_{\min }=0.986, T_{\max }=0.993$

\section{Refinement}

Refinement on $F^{2}$

Least-squares matrix: full

$R\left[F^{2}>2 \sigma\left(F^{2}\right)\right]=0.062$

$w R\left(F^{2}\right)=0.130$

$S=0.95$

2413 reflections

194 parameters

0 restraints
$F(000)=1080$

$D_{\mathrm{x}}=1.246 \mathrm{Mg} \mathrm{m}^{-3}$

Mo $K \alpha$ radiation, $\lambda=0.71073 \AA$

Cell parameters from 380 reflections

$\theta=2.5-26.0^{\circ}$

$\mu=0.07 \mathrm{~mm}^{-1}$

$T=298 \mathrm{~K}$

Block, yellow

$0.30 \times 0.16 \times 0.10 \mathrm{~mm}$

6631 measured reflections

2413 independent reflections

1197 reflections with $I>2 \sigma(I)$

$R_{\text {int }}=0.058$

$\theta_{\text {max }}=25.0^{\circ}, \theta_{\text {min }}=1.7^{\circ}$

$h=-31 \rightarrow 29$

$k=-11 \rightarrow 11$

$l=-14 \rightarrow 12$

Hydrogen site location: inferred from neighbouring sites

Only $\mathrm{H}$-atom displacement parameters refined

$w=1 /\left[\sigma^{2}\left(F_{\mathrm{o}}^{2}\right)+(0.0447 P)^{2}\right]$

where $P=\left(F_{\mathrm{o}}^{2}+2 F_{\mathrm{c}}^{2}\right) / 3$

$(\Delta / \sigma)_{\max }<0.001$

$\Delta \rho_{\max }=0.11$ e $\AA^{-3}$

$\Delta \rho_{\min }=-0.10$ e $\AA^{-3}$

Special details

Geometry. All esds (except the esd in the dihedral angle between two 1.s. planes) are estimated using the full covariance matrix. The cell esds are taken into account individually in the estimation of esds in distances, angles and torsion angles; correlations between esds in cell parameters are only used when they are defined by crystal symmetry. An approximate (isotropic) treatment of cell esds is used for estimating esds involving l.s. planes.

Refinement. Refinement of $\mathrm{F}^{2}$ against ALL reflections. The weighted R-factor wR and goodness of fit $\mathrm{S}$ are based on $\mathrm{F}^{2}$, conventional R-factors $R$ are based on $F$, with $F$ set to zero for negative $F^{2}$. The threshold expression of $F^{2}>2 \operatorname{sigma}\left(\mathrm{F}^{2}\right)$ is used only for calculating R-factors(gt) etc. and is not relevant to the choice of reflections for refinement. R-factors based on $\mathrm{F}^{2}$ are statistically about twice as large as those based on F, and R- factors based on ALL data will be even larger.

Fractional atomic coordinates and isotropic or equivalent isotropic displacement parameters $\left(\AA^{2}\right)$

\begin{tabular}{lllll}
\hline & $x$ & $y$ & $z$ & $U_{\text {iso }} * U_{\text {eq }}$ \\
\hline C1 & $0.47469(10)$ & $0.0592(3)$ & $0.1862(2)$ & $0.0498(7)$ \\
C2 & $0.42618(10)$ & $-0.0283(3)$ & $0.1669(2)$ & $0.0492(7)$ \\
C3 & $0.38212(11)$ & $-0.0443(3)$ & $0.0497(3)$ & $0.0657(8)$
\end{tabular}




$\begin{array}{lllll}\text { H3 } & 0.382634 & 0.002388 & -0.018428 & 0.065(8)^{*} \\ \text { C4 } & 0.33781(13) & -0.1281(3) & 0.0331(3) & 0.0816(10) \\ \text { H4 } & 0.308409 & -0.137174 & -0.046358 & 0.075(9)^{*} \\ \text { C5 } & 0.33585(14) & -0.1977(3) & 0.1294(3) & 0.0845(10) \\ \text { H5 } & 0.305668 & -0.255394 & 0.116304 & 0.074(9)^{*} \\ \text { C6 } & 0.37835(14) & -0.1830(3) & 0.2459(4) & 0.0864(10) \\ \text { H6 } & 0.377201 & -0.229986 & 0.313221 & 0.097(11)^{*} \\ \text { C7 } & 0.42297(12) & -0.0986(3) & 0.2640(3) & 0.0715(9) \\ \text { H7 } & 0.451750 & -0.088900 & 0.344135 & 0.052(7)^{*} \\ \text { C8 } & 0.52380(14) & 0.2815(3) & 0.0423(3) & 0.0670(8) \\ \text { H8 } & 0.489868 & 0.285791 & -0.029219 & 0.085(11)^{*} \\ \text { C9 } & 0.56973(13) & 0.3652(3) & 0.0431(3) & 0.0660(8) \\ \text { C10 } & 0.55680(17) & 0.4528(3) & -0.0558(3) & 0.0855(10) \\ \text { H10 } & 0.520013 & 0.454005 & -0.118007 & 0.117(14)^{*} \\ \text { C11 } & 0.59585(18) & 0.5391(4) & -0.0671(4) & 0.1027(12) \\ \text { H11 } & 0.585478 & 0.598432 & -0.134758 & 0.100(11)^{*} \\ \text { C12 } & 0.65000(19) & 0.5357(4) & 0.0229(4) & 0.1035(12) \\ \text { H12 } & 0.676527 & 0.593874 & 0.015764 & 0.123(13)^{*} \\ \text { C13 } & 0.66715(15) & 0.4466(3) & 0.1267(3) & 0.0799(9) \\ \text { C14 } & 0.62661(13) & 0.3581(3) & 0.1381(3) & 0.0635(8) \\ \text { C15 } & 0.64564(14) & 0.2666(3) & 0.2393(3) & 0.0694(8) \\ \text { H15 } & 0.619942 & 0.207560 & 0.248826 & 0.077(9)^{*} \\ \text { C16 } & 0.70059(14) & 0.2621(4) & 0.3236(3) & 0.0824(10) \\ \text { H16 } & 0.712101 & 0.200221 & 0.389491 & 0.097(12)^{*} \\ \text { C17 } & 0.73971(18) & 0.3498(4) & 0.3116(4) & 0.1014(12) \\ \text { H17 } & 0.777285 & 0.346277 & 0.369719 & 0.112(13)^{*} \\ \text { C18 } & 0.72364(17) & 0.4395(4) & 0.2167(4) & 0.1034(12) \\ \text { H18 } & 0.750268 & 0.497894 & 0.210383 & 0.086(10)^{*} \\ \text { N1 } & 0.47400(9) & 0.1318(2) & 0.0954(2) & 0.0609(6) \\ \text { N2 } & 0.52522(9) & 0.2036(2) & 0.1286(2) & 0.0634(7)\end{array}$

Atomic displacement parameters $\left(\AA^{2}\right)$

\begin{tabular}{lllllll}
\hline & $U^{11}$ & $U^{22}$ & $U^{33}$ & $U^{12}$ & $U^{13}$ & $U^{23}$ \\
\hline C1 & $0.0526(17)$ & $0.0542(16)$ & $0.0440(15)$ & $0.0071(13)$ & $0.0219(13)$ & $-0.0013(13)$ \\
C2 & $0.0451(16)$ & $0.0574(17)$ & $0.0440(16)$ & $0.0016(13)$ & $0.0179(15)$ & $-0.0031(14)$ \\
C3 & $0.0600(19)$ & $0.084(2)$ & $0.0522(19)$ & $-0.0039(17)$ & $0.0225(18)$ & $-0.0002(17)$ \\
C4 & $0.054(2)$ & $0.111(3)$ & $0.070(2)$ & $-0.0156(19)$ & $0.017(2)$ & $-0.017(2)$ \\
C5 & $0.065(2)$ & $0.100(3)$ & $0.095(3)$ & $-0.030(2)$ & $0.040(2)$ & $-0.019(2)$ \\
C6 & $0.085(3)$ & $0.096(3)$ & $0.082(3)$ & $-0.025(2)$ & $0.039(2)$ & $0.006(2)$ \\
C7 & $0.062(2)$ & $0.087(2)$ & $0.056(2)$ & $-0.0173(17)$ & $0.0163(19)$ & $0.0009(17)$ \\
C8 & $0.072(2)$ & $0.064(2)$ & $0.065(2)$ & $0.0010(16)$ & $0.029(2)$ & $0.0022(16)$ \\
C9 & $0.074(2)$ & $0.0621(19)$ & $0.068(2)$ & $-0.0001(17)$ & $0.036(2)$ & $0.0008(17)$ \\
C10 & $0.100(3)$ & $0.081(3)$ & $0.087(3)$ & $0.000(2)$ & $0.051(3)$ & $0.022(2)$ \\
C11 & $0.123(3)$ & $0.091(3)$ & $0.108(3)$ & $0.014(3)$ & $0.063(3)$ & $0.036(3)$ \\
C12 & $0.128(3)$ & $0.084(3)$ & $0.131(4)$ & $-0.009(3)$ & $0.086(3)$ & $0.019(3)$ \\
C13 & $0.087(3)$ & $0.074(2)$ & $0.094(3)$ & $-0.012(2)$ & $0.053(2)$ & $-0.005(2)$ \\
C14 & $0.078(2)$ & $0.0603(19)$ & $0.064(2)$ & $-0.0020(17)$ & $0.0415(19)$ & $-0.0036(16)$
\end{tabular}




\begin{tabular}{lllllll}
$\mathrm{C} 15$ & $0.065(2)$ & $0.080(2)$ & $0.067(2)$ & $-0.0083(19)$ & $0.031(2)$ & $-0.0062(17)$ \\
$\mathrm{C} 16$ & $0.071(2)$ & $0.096(3)$ & $0.078(2)$ & $-0.005(2)$ & $0.029(2)$ & $-0.004(2)$ \\
$\mathrm{C} 17$ & $0.076(3)$ & $0.120(4)$ & $0.110(3)$ & $-0.017(2)$ & $0.040(3)$ & $-0.002(3)$ \\
$\mathrm{C} 18$ & $0.091(3)$ & $0.103(3)$ & $0.128(4)$ & $-0.028(3)$ & $0.057(3)$ & $-0.004(3)$ \\
$\mathrm{N} 1$ & $0.0583(15)$ & $0.0688(16)$ & $0.0549(15)$ & $-0.0016(13)$ & $0.0235(13)$ & $0.0049(12)$ \\
$\mathrm{N} 2$ & $0.0633(16)$ & $0.0688(16)$ & $0.0597(16)$ & $-0.0061(13)$ & $0.0278(14)$ & $0.0139(13)$ \\
\hline
\end{tabular}

Geometric parameters $\left(\AA,{ }^{\circ}\right)$

\begin{tabular}{|c|c|c|c|}
\hline $\mathrm{C} 1-\mathrm{N} 1$ & $1.280(3)$ & $\mathrm{C} 9-\mathrm{C} 14$ & $1.434(3)$ \\
\hline $\mathrm{C} 1-\mathrm{C} 2$ & $1.469(3)$ & $\mathrm{C} 10-\mathrm{C} 11$ & $1.378(4)$ \\
\hline $\mathrm{C} 1-\mathrm{Cl}^{\mathrm{i}}$ & $1.525(4)$ & $\mathrm{C} 10-\mathrm{H} 10$ & 0.9300 \\
\hline $\mathrm{C} 2-\mathrm{C} 7$ & $1.371(3)$ & $\mathrm{C} 11-\mathrm{C} 12$ & $1.363(4)$ \\
\hline $\mathrm{C} 2-\mathrm{C} 3$ & $1.382(3)$ & $\mathrm{C} 11-\mathrm{H} 11$ & 0.9300 \\
\hline $\mathrm{C} 3-\mathrm{C} 4$ & $1.367(4)$ & $\mathrm{C} 12-\mathrm{C} 13$ & $1.414(4)$ \\
\hline $\mathrm{C} 3-\mathrm{H} 3$ & 0.9300 & $\mathrm{C} 12-\mathrm{H} 12$ & 0.9300 \\
\hline $\mathrm{C} 4-\mathrm{C} 5$ & $1.346(4)$ & $\mathrm{C} 13-\mathrm{C} 18$ & 1.409 (4) \\
\hline $\mathrm{C} 4-\mathrm{H} 4$ & 0.9300 & $\mathrm{C} 13-\mathrm{C} 14$ & $1.422(4)$ \\
\hline $\mathrm{C} 5-\mathrm{C} 6$ & $1.359(4)$ & $\mathrm{C} 14-\mathrm{C} 15$ & $1.406(4)$ \\
\hline $\mathrm{C} 5-\mathrm{H} 5$ & 0.9300 & $\mathrm{C} 15-\mathrm{C} 16$ & $1.357(4)$ \\
\hline $\mathrm{C} 6-\mathrm{C} 7$ & $1.373(4)$ & $\mathrm{C} 15-\mathrm{H} 15$ & 0.9300 \\
\hline C6- $-\mathrm{H} 6$ & 0.9300 & $\mathrm{C} 16-\mathrm{C} 17$ & $1.390(4)$ \\
\hline $\mathrm{C} 7-\mathrm{H} 7$ & 0.9300 & $\mathrm{C} 16-\mathrm{H} 16$ & 0.9300 \\
\hline $\mathrm{C} 8-\mathrm{N} 2$ & $1.261(3)$ & $\mathrm{C} 17-\mathrm{C} 18$ & $1.343(4)$ \\
\hline $\mathrm{C} 8-\mathrm{C} 9$ & $1.453(4)$ & $\mathrm{C} 17-\mathrm{H} 17$ & 0.9300 \\
\hline $\mathrm{C} 8-\mathrm{H} 8$ & 0.9300 & $\mathrm{C} 18-\mathrm{H} 18$ & 0.9300 \\
\hline $\mathrm{C} 9-\mathrm{C} 10$ & $1.371(4)$ & $\mathrm{N} 1-\mathrm{N} 2$ & $1.415(3)$ \\
\hline $\mathrm{N} 1-\mathrm{C} 1-\mathrm{C} 2$ & $119.5(2)$ & $\mathrm{C} 9-\mathrm{C} 10-\mathrm{H} 10$ & 118.5 \\
\hline $\mathrm{N} 1-\mathrm{C} 1-\mathrm{C} 1^{\mathrm{i}}$ & $121.5(2)$ & $\mathrm{C} 11-\mathrm{C} 10-\mathrm{H} 10$ & 118.5 \\
\hline $\mathrm{C} 2-\mathrm{C} 1-\mathrm{C} 1^{\mathrm{i}}$ & $118.9(2)$ & $\mathrm{C} 12-\mathrm{C} 11-\mathrm{C} 10$ & $118.6(4)$ \\
\hline $\mathrm{C} 7-\mathrm{C} 2-\mathrm{C} 3$ & $117.3(3)$ & $\mathrm{C} 12-\mathrm{C} 11-\mathrm{H} 11$ & 120.7 \\
\hline $\mathrm{C} 7-\mathrm{C} 2-\mathrm{C} 1$ & $121.5(2)$ & $\mathrm{C} 10-\mathrm{C} 11-\mathrm{H} 11$ & 120.7 \\
\hline $\mathrm{C} 3-\mathrm{C} 2-\mathrm{C} 1$ & $121.3(3)$ & $\mathrm{C} 11-\mathrm{C} 12-\mathrm{C} 13$ & $122.1(4)$ \\
\hline $\mathrm{C} 4-\mathrm{C} 3-\mathrm{C} 2$ & $120.5(3)$ & $\mathrm{C} 11-\mathrm{C} 12-\mathrm{H} 12$ & 118.9 \\
\hline $\mathrm{C} 4-\mathrm{C} 3-\mathrm{H} 3$ & 119.8 & $\mathrm{C} 13-\mathrm{C} 12-\mathrm{H} 12$ & 118.9 \\
\hline $\mathrm{C} 2-\mathrm{C} 3-\mathrm{H} 3$ & 119.8 & $\mathrm{C} 18-\mathrm{C} 13-\mathrm{C} 12$ & $121.9(4)$ \\
\hline $\mathrm{C} 5-\mathrm{C} 4-\mathrm{C} 3$ & $121.3(3)$ & $\mathrm{C} 18-\mathrm{C} 13-\mathrm{C} 14$ & $119.0(3)$ \\
\hline $\mathrm{C} 5-\mathrm{C} 4-\mathrm{H} 4$ & 119.3 & $\mathrm{C} 12-\mathrm{C} 13-\mathrm{C} 14$ & $119.0(3)$ \\
\hline $\mathrm{C} 3-\mathrm{C} 4-\mathrm{H} 4$ & 119.3 & $\mathrm{C} 15-\mathrm{C} 14-\mathrm{C} 13$ & $117.5(3)$ \\
\hline $\mathrm{C} 4-\mathrm{C} 5-\mathrm{C} 6$ & $119.4(3)$ & $\mathrm{C} 15-\mathrm{C} 14-\mathrm{C} 9$ & $124.7(3)$ \\
\hline $\mathrm{C} 4-\mathrm{C} 5-\mathrm{H} 5$ & 120.3 & $\mathrm{C} 13-\mathrm{C} 14-\mathrm{C} 9$ & $117.7(3)$ \\
\hline $\mathrm{C} 6-\mathrm{C} 5-\mathrm{H} 5$ & 120.3 & $\mathrm{C} 16-\mathrm{C} 15-\mathrm{C} 14$ & $121.6(3)$ \\
\hline $\mathrm{C} 5-\mathrm{C} 6-\mathrm{C} 7$ & $119.8(3)$ & $\mathrm{C} 16-\mathrm{C} 15-\mathrm{H} 15$ & 119.2 \\
\hline $\mathrm{C} 5-\mathrm{C} 6-\mathrm{H} 6$ & 120.1 & $\mathrm{C} 14-\mathrm{C} 15-\mathrm{H} 15$ & 119.2 \\
\hline $\mathrm{C} 7-\mathrm{C} 6-\mathrm{H} 6$ & 120.1 & $\mathrm{C} 15-\mathrm{C} 16-\mathrm{C} 17$ & $120.2(4)$ \\
\hline $\mathrm{C} 2-\mathrm{C} 7-\mathrm{C} 6$ & $121.7(3)$ & $\mathrm{C} 15-\mathrm{C} 16-\mathrm{H} 16$ & 119.9 \\
\hline $\mathrm{C} 2-\mathrm{C} 7-\mathrm{H} 7$ & 119.2 & $\mathrm{C} 17-\mathrm{C} 16-\mathrm{H} 16$ & 119.9 \\
\hline
\end{tabular}




$\begin{array}{llll}\mathrm{C} 6-\mathrm{C} 7-\mathrm{H} 7 & 119.2 & \mathrm{C} 18-\mathrm{C} 17-\mathrm{C} 16 & 120.5(4) \\ \mathrm{N} 2-\mathrm{C} 8-\mathrm{C} 9 & 126.7(3) & \mathrm{C} 18-\mathrm{C} 17-\mathrm{H} 17 & 119.8 \\ \mathrm{~N} 2-\mathrm{C} 8-\mathrm{H} 8 & 116.7 & \mathrm{C} 16-\mathrm{C} 17-\mathrm{H} 17 & 119.8 \\ \mathrm{C} 9-\mathrm{C} 8-\mathrm{H} 8 & 116.7 & \mathrm{C} 17-\mathrm{C} 18-\mathrm{C} 13 & 121.1(4) \\ \mathrm{C} 10-\mathrm{C} 9-\mathrm{C} 14 & 119.5(3) & \mathrm{C} 17-\mathrm{C} 18-\mathrm{H} 18 & 119.4 \\ \mathrm{C} 10-\mathrm{C} 9-\mathrm{C} 8 & 116.4(3) & \mathrm{C} 13-\mathrm{C} 18-\mathrm{H} 18 & 119.4 \\ \mathrm{C} 14-\mathrm{C} 9-\mathrm{C} 8 & 124.0(3) & \mathrm{C} 1-\mathrm{N} 1-\mathrm{N} 2 & 111.8(2) \\ \mathrm{C} 9-\mathrm{C} 10-\mathrm{C} 11 & 123.0(4) & \mathrm{C} 8-\mathrm{N} 2-\mathrm{N} 1 & 112.3(2)\end{array}$

Symmetry code: (i) $-x+1, y,-z+1 / 2$.

Hydrogen-bond geometry $\left(\AA,{ }^{\circ}\right)$

\begin{tabular}{lllll}
\hline$D-\mathrm{H} \cdots A$ & $D-\mathrm{H}$ & $\mathrm{H} \cdots A$ & $D \cdots A$ & $D-\mathrm{H} \cdots A$ \\
\hline $\mathrm{C} 15-\mathrm{H} 15 \cdots \mathrm{N} 2$ & 0.93 & 2.27 & $2.920(4)$ & 126 \\
\hline
\end{tabular}

(Z)-2-\{(E)-[(1H-Indol-3-yl)methylidene]hydrazinylidene\}-\1,2-diphenylethanone (5-BMHFI)

\section{Crystal data}

$\mathrm{C}_{23} \mathrm{H}_{17} \mathrm{~N}_{3} \mathrm{O}$

$M_{r}=351.39$

Orthorhombic, $P 2{ }_{1} 2{ }_{1} 2_{1}$

$a=6.8767$ (1) $\AA$

$b=8.3698(2) \AA$

$c=32.6317(6) \AA$

$V=1878.17(6) \AA^{3}$

$Z=4$

$F(000)=736$

\section{Data collection}

Bruker SMART CCD area detector diffractometer

Radiation source: fine-focus sealed tube Detector resolution: 10.11 pixels $\mathrm{mm}^{-1}$ phi and $\omega$ scans

Absorption correction: multi-scan

(SADABS; Bruker, 2000)

$T_{\min }=0.903, T_{\max }=0.939$

\section{Refinement}

Refinement on $F^{2}$

Least-squares matrix: full

$R\left[F^{2}>2 \sigma\left(F^{2}\right)\right]=0.035$

$w R\left(F^{2}\right)=0.096$

$S=1.02$

3641 reflections

262 parameters

0 restraints

Hydrogen site location: inferred from neighbouring sites

Only $\mathrm{H}$-atom displacement parameters refined $w=1 /\left[\sigma^{2}\left(F_{\mathrm{o}}^{2}\right)+(0.0555 P)^{2}+0.1425 P\right]$ where $P=\left(F_{\mathrm{o}}^{2}+2 F_{\mathrm{c}}{ }^{2}\right) / 3$
$D_{\mathrm{x}}=1.243 \mathrm{Mg} \mathrm{m}^{-3}$

Melting point: $470.4 \mathrm{~K}$

Mo $K \alpha$ radiation, $\lambda=0.71073 \AA$

Cell parameters from 380 reflections

$\theta=2.5-26.0^{\circ}$

$\mu=0.08 \mathrm{~mm}^{-1}$

$T=293 \mathrm{~K}$

Needle, yellow

$0.35 \times 0.1 \times 0.09 \mathrm{~mm}$

10418 measured reflections

3641 independent reflections

3444 reflections with $I>2 \sigma(I)$

$R_{\text {int }}=0.023$

$\theta_{\max }=26.1^{\circ}, \theta_{\min }=2.5^{\circ}$

$h=-7 \rightarrow 8$

$k=-10 \rightarrow 10$

$l=-39 \rightarrow 40$

$(\Delta / \sigma)_{\max }=0.001$

$\Delta \rho_{\max }=0.15$ e $\AA^{-3}$

$\Delta \rho_{\min }=-0.13$ e $\AA^{-3}$

Extinction correction: SHELXL2016

(Sheldrick, 2015b),

$\mathrm{Fc}^{*}=\mathrm{kFc}\left[1+0.001 \mathrm{xFc}^{2} \lambda^{3} / \sin (2 \theta)\right]^{-1 / 4}$

Extinction coefficient: 0.014 (2)

Absolute structure: Flack $x$ determined using

1312 quotients [(I+)-(I-)]/[(I+)+(I-)] (Parsons et al., 2013)

The diffraction data did not permit a clear determination of the absolute structure.

Absolute structure parameter: -1.4 (6) 


\section{Special details}

Geometry. All esds (except the esd in the dihedral angle between two 1.s. planes) are estimated using the full covariance matrix. The cell esds are taken into account individually in the estimation of esds in distances, angles and torsion angles; correlations between esds in cell parameters are only used when they are defined by crystal symmetry. An approximate (isotropic) treatment of cell esds is used for estimating esds involving l.s. planes.

Refinement. Refinement of $\mathrm{F}^{2}$ against ALL reflections. The weighted R-factor $\mathrm{wR}$ and goodness of fit $\mathrm{S}$ are based on $\mathrm{F}^{2}$, conventional $R$-factors $R$ are based on $F$, with $F$ set to zero for negative $F^{2}$. The threshold expression of $F^{2}>2 \operatorname{sigma}\left(\mathrm{F}^{2}\right)$ is used only for calculating R-factors(gt) etc. and is not relevant to the choice of reflections for refinement. R-factors based on $\mathrm{F}^{2}$ are statistically about twice as large as those based on F, and R- factors based on ALL data will be even larger.

Fractional atomic coordinates and isotropic or equivalent isotropic displacement parameters $\left(\hat{A}^{2}\right)$

\begin{tabular}{|c|c|c|c|c|}
\hline & $x$ & $y$ & $z$ & $U_{\text {iso }} * / U_{\text {eq }}$ \\
\hline $\mathrm{C} 1$ & $0.7517(3)$ & $0.2656(2)$ & $0.85621(6)$ & $0.0427(4)$ \\
\hline $\mathrm{C} 2$ & $0.8141(3)$ & $0.1859(2)$ & $0.81814(6)$ & $0.0470(4)$ \\
\hline $\mathrm{C} 3$ & $1.0008(4)$ & 0.1258 & $0.81425(7)$ & $0.0669(6)$ \\
\hline $\mathrm{H} 3$ & 1.089269 & 0.138070 & 0.835570 & $0.076(8)^{*}$ \\
\hline $\mathrm{C} 4$ & $1.0561(5)$ & $0.0477(4)$ & $0.77895(9)$ & $0.0874(9)$ \\
\hline $\mathrm{H} 4$ & 1.181704 & 0.007482 & 0.776671 & $0.106(11)^{*}$ \\
\hline $\mathrm{C} 5$ & $0.9281(5)$ & $0.0289(4)$ & $0.74721(9)$ & $0.0923(10)$ \\
\hline H5 & 0.966311 & -0.024678 & 0.723578 & $0.102(10)^{*}$ \\
\hline C6 & $0.7443(5)$ & $0.0890(4)$ & $0.75035(8)$ & $0.0843(9)$ \\
\hline H6 & 0.657486 & 0.076835 & 0.728722 & $0.100(10)^{*}$ \\
\hline $\mathrm{C} 7$ & $0.6864(4)$ & $0.1677(3)$ & $0.78550(7)$ & $0.0636(6)$ \\
\hline $\mathrm{H} 7$ & 0.561082 & 0.208836 & 0.787316 & $0.062(7)^{*}$ \\
\hline $\mathrm{C} 8$ & 0.5398 & $0.3144(2)$ & $0.86038(5)$ & $0.0423(4)$ \\
\hline C9 & 0.4897 & $0.4854(3)$ & $0.85595(6)$ & $0.0494(5)$ \\
\hline C10 & $0.2996(4)$ & $0.5330(4)$ & $0.86342(7)$ & $0.0711(7)$ \\
\hline $\mathrm{H} 10$ & 0.205386 & 0.458336 & 0.870592 & $0.079(9)^{*}$ \\
\hline C11 & $0.2525(7)$ & $0.6924(5)$ & $0.86005(11)$ & $0.1074(13)$ \\
\hline H11 & 0.125781 & 0.725582 & 0.865180 & $0.136(15)^{*}$ \\
\hline C12 & $0.3901(8)$ & $0.8024(4)$ & $0.84926(12)$ & $0.1188(16)$ \\
\hline H12 & 0.356149 & 0.909601 & 0.847176 & $0.119(12)^{*}$ \\
\hline C13 & $0.5766(7)$ & $0.7565(4)$ & $0.84152(11)$ & $0.1043(12)$ \\
\hline H13 & 0.669543 & 0.831779 & 0.834033 & $0.160(18)^{*}$ \\
\hline C14 & 0.6268 & $0.5965(3)$ & $0.84490(8)$ & $0.0704(7)$ \\
\hline $\mathrm{H} 14$ & 0.753805 & 0.564317 & 0.839654 & $0.079(9)^{*}$ \\
\hline C15 & $0.8754(3)$ & $0.3567(2)$ & $0.95253(6)$ & $0.0472(4)$ \\
\hline H15 & 1.003366 & 0.321156 & 0.951208 & $0.050(6)^{*}$ \\
\hline C16 & $0.7994(3)$ & $0.4113(2)$ & $0.99091(6)$ & $0.0457(4)$ \\
\hline $\mathrm{C} 17$ & 0.6165 & $0.4884(2)$ & $1.00009(6)$ & $0.0438(4)$ \\
\hline C18 & $0.4611(3)$ & $0.5458(2)$ & $0.97686(7)$ & $0.0521(5)$ \\
\hline H18 & 0.462304 & 0.536961 & 0.948449 & $0.058(6)^{*}$ \\
\hline C19 & $0.3066(4)$ & $0.6156(3)$ & $0.99655(8)$ & $0.0646(6)$ \\
\hline H19 & 0.203049 & 0.654739 & 0.981207 & $0.073(7)^{*}$ \\
\hline $\mathrm{C} 20$ & $0.3018(4)$ & 0.6290 & $1.03919(8)$ & $0.0685(6)$ \\
\hline $\mathrm{H} 20$ & 0.195263 & 0.676936 & 1.051704 & $0.074(8)^{*}$ \\
\hline $\mathrm{C} 21$ & $0.4506(4)$ & $0.5730(3)$ & $1.06286(7)$ & $0.0614(6)$ \\
\hline
\end{tabular}




$\begin{array}{lllll}\mathrm{H} 21 & 0.446523 & 0.580472 & 1.091284 & 0.068(7)^{*} \\ \mathrm{C} 22 & 0.6087(3) & 0.5045(2) & 1.04290(6) & 0.0490(5) \\ \mathrm{C} 23 & 0.8892(3) & 0.3850(3) & 1.02803(6) & 0.0558(5) \\ \mathrm{H} 23 & 1.009720 & 0.336291 & 1.031394 & 0.063(7)^{*} \\ \mathrm{~N} 1 & 0.8691(2) & 0.2859(2) & 0.88638(5) & 0.0493(4) \\ \mathrm{N} 2 & 0.7709(2) & 0.3555(2) & 0.91982(5) & 0.0481(4) \\ \mathrm{N} 3 & 0.7772(3) & 0.4399(2) & 1.05867(5) & 0.0580(5) \\ \mathrm{H} 24 & 0.806292 & 0.435508 & 1.084278 & 0.087(9)^{*} \\ \mathrm{O} 1 & 0.4184(2) & 0.21208(19) & 0.86624(5) & 0.0593(4)\end{array}$

Atomic displacement parameters $\left(\AA^{2}\right)$

\begin{tabular}{lllllll}
\hline & $U^{11}$ & $U^{22}$ & $U^{33}$ & $U^{12}$ & $U^{13}$ & $U^{33}$ \\
\hline C1 & $0.0455(9)$ & $0.0417(9)$ & $0.0410(9)$ & $0.0001(8)$ & $0.0002(8)$ & $0.0052(7)$ \\
C2 & $0.0552(11)$ & $0.0454(10)$ & $0.0403(9)$ & $0.0018(9)$ & $0.0022(8)$ & $0.0040(8)$ \\
C3 & $0.0636(13)$ & $0.0814(16)$ & $0.0558(12)$ & $0.0192(13)$ & $0.0002(11)$ & $-0.0060(12)$ \\
C4 & $0.0847(19)$ & $0.106(2)$ & $0.0712(16)$ & $0.0347(18)$ & $0.0091(14)$ & $-0.0160(15)$ \\
C5 & $0.115(2)$ & $0.105(2)$ & $0.0569(14)$ & $0.026(2)$ & $0.0091(16)$ & $-0.0225(14)$ \\
C6 & $0.095(2)$ & $0.111(2)$ & $0.0468(12)$ & $0.0072(19)$ & $-0.0077(13)$ & $-0.0148(13)$ \\
C7 & $0.0627(14)$ & $0.0796(16)$ & $0.0486(11)$ & $0.0074(12)$ & $-0.0031(10)$ & $-0.0037(11)$ \\
C8 & $0.0438(9)$ & $0.0491(10)$ & $0.0342(8)$ & $-0.0034(8)$ & $0.0009(7)$ & $0.0032(7)$ \\
C9 & $0.0552(10)$ & $0.0531(11)$ & $0.0400(9)$ & $0.0087(9)$ & $-0.0072(8)$ & $-0.0021(8)$ \\
C10 & $0.0679(14)$ & $0.0868(18)$ & $0.0585(13)$ & $0.0256(15)$ & $-0.0039(11)$ & $-0.0098(12)$ \\
C11 & $0.117(3)$ & $0.108(3)$ & $0.097(2)$ & $0.069(2)$ & $-0.023(2)$ & $-0.030(2)$ \\
C12 & $0.181(4)$ & $0.0616(18)$ & $0.114(3)$ & $0.048(3)$ & $-0.063(3)$ & $-0.0235(19)$ \\
C13 & $0.150(3)$ & $0.0520(15)$ & $0.111(3)$ & $-0.002(2)$ & $-0.043(3)$ & $0.0109(15)$ \\
C14 & $0.0793(17)$ & $0.0521(12)$ & $0.0798(16)$ & $-0.0026(12)$ & $-0.0157(14)$ & $0.0109(11)$ \\
C15 & $0.0434(9)$ & $0.0473(10)$ & $0.0509(10)$ & $0.0047(9)$ & $-0.0062(8)$ & $-0.0019(8)$ \\
C16 & $0.0475(10)$ & $0.0425(9)$ & $0.0469(9)$ & $0.0014(8)$ & $-0.0118(8)$ & $-0.0030(8)$ \\
C17 & $0.0496(10)$ & $0.0350(8)$ & $0.0467(9)$ & $-0.0023(8)$ & $-0.0065(8)$ & $-0.0021(7)$ \\
C18 & $0.0551(11)$ & $0.0477(10)$ & $0.0535(11)$ & $0.0026(9)$ & $-0.0131(9)$ & $0.0002(9)$ \\
C19 & $0.0568(13)$ & $0.0599(13)$ & $0.0770(15)$ & $0.0121(11)$ & $-0.0091(12)$ & $-0.0001(11)$ \\
C20 & $0.0628(14)$ & $0.0628(14)$ & $0.0798(16)$ & $0.0096(12)$ & $0.0087(13)$ & $-0.0073(12)$ \\
C21 & $0.0763(15)$ & $0.0548(12)$ & $0.0531(12)$ & $0.0016(12)$ & $0.0053(11)$ & $-0.0072(10)$ \\
C22 & $0.0602(12)$ & $0.0402(10)$ & $0.0466(10)$ & $0.0005(9)$ & $-0.0058(9)$ & $-0.0012(8)$ \\
C23 & $0.0575(12)$ & $0.0551(11)$ & $0.0548(11)$ & $0.0090(10)$ & $-0.0158(10)$ & $-0.0058(9)$ \\
N1 & $0.0456(9)$ & $0.0585(10)$ & $0.0437(8)$ & $0.0059(8)$ & $-0.0012(7)$ & $-0.0030(7)$ \\
N2 & $0.0450(8)$ & $0.0569(9)$ & $0.0424(8)$ & $0.0056(8)$ & $-0.0019(7)$ & $-0.0038(7)$ \\
N3 & $0.0738(12)$ & $0.0595(10)$ & $0.0407(9)$ & $0.0084(10)$ & $-0.0158(8)$ & $-0.0051(7)$ \\
O1 & $0.0542(8)$ & $0.0652(9)$ & $0.0586(9)$ & $-0.0152(8)$ & $0.0019(7)$ & $0.0079(7)$ \\
& & & & & & \\
\hline & & & & & & \\
\hline
\end{tabular}

Geometric parameters $\left(\AA,{ }^{\circ}\right)$

\begin{tabular}{llll}
\hline $\mathrm{C} 1-\mathrm{N} 1$ & $1.284(3)$ & $\mathrm{C} 13-\mathrm{C} 14$ & $1.387(4)$ \\
$\mathrm{C} 1-\mathrm{C} 2$ & $1.474(3)$ & $\mathrm{C} 13-\mathrm{H} 13$ & 0.9300 \\
$\mathrm{C} 1-\mathrm{C} 8$ & $1.520(3)$ & $\mathrm{C} 14-\mathrm{H} 14$ & 0.9300 \\
$\mathrm{C} 2-\mathrm{C} 3$ & $1.385(3)$ & $\mathrm{C} 15-\mathrm{N} 2$ & $1.287(2)$ \\
$\mathrm{C} 2-\mathrm{C} 7$ & $1.389(3)$ & $\mathrm{C} 15-\mathrm{C} 16$ & $1.432(3)$
\end{tabular}




\begin{tabular}{|c|c|c|c|}
\hline $\mathrm{C} 3-\mathrm{C} 4$ & $1.378(4)$ & $\mathrm{C} 15-\mathrm{H} 15$ & 0.9300 \\
\hline $\mathrm{C} 3-\mathrm{H} 3$ & 0.9300 & $\mathrm{C} 16-\mathrm{C} 23$ & $1.377(3)$ \\
\hline $\mathrm{C} 4-\mathrm{C} 5$ & $1.368(4)$ & $\mathrm{C} 16-\mathrm{C} 17$ & $1.445(3)$ \\
\hline $\mathrm{C} 4-\mathrm{H} 4$ & 0.9300 & $\mathrm{C} 17-\mathrm{C} 18$ & $1.395(3)$ \\
\hline $\mathrm{C} 5-\mathrm{C} 6$ & $1.364(4)$ & $\mathrm{C} 17-\mathrm{C} 22$ & $1.404(3)$ \\
\hline $\mathrm{C} 5-\mathrm{H} 5$ & 0.9300 & $\mathrm{C} 18-\mathrm{C} 19$ & $1.372(3)$ \\
\hline $\mathrm{C} 6-\mathrm{C} 7$ & $1.381(3)$ & $\mathrm{C} 18-\mathrm{H} 18$ & 0.9300 \\
\hline $\mathrm{C} 6-\mathrm{H} 6$ & 0.9300 & $\mathrm{C} 19-\mathrm{C} 20$ & $1.396(4)$ \\
\hline $\mathrm{C} 7-\mathrm{H} 7$ & 0.9300 & $\mathrm{C} 19-\mathrm{H} 19$ & 0.9300 \\
\hline $\mathrm{C} 8-\mathrm{O} 1$ & $1.211(2)$ & $\mathrm{C} 20-\mathrm{C} 21$ & $1.365(3)$ \\
\hline $\mathrm{C} 8-\mathrm{C} 9$ & $1.479(3)$ & $\mathrm{C} 20-\mathrm{H} 20$ & 0.9300 \\
\hline $\mathrm{C} 9-\mathrm{C} 14$ & $1.372(3)$ & $\mathrm{C} 21-\mathrm{C} 22$ & $1.391(3)$ \\
\hline $\mathrm{C} 9-\mathrm{C} 10$ & $1.388(3)$ & $\mathrm{C} 21-\mathrm{H} 21$ & 0.9300 \\
\hline $\mathrm{C} 10-\mathrm{C} 11$ & $1.378(5)$ & $\mathrm{C} 22-\mathrm{N} 3$ & $1.378(3)$ \\
\hline $\mathrm{C} 10-\mathrm{H} 10$ & 0.9300 & $\mathrm{C} 23-\mathrm{N} 3$ & $1.343(3)$ \\
\hline $\mathrm{C} 11-\mathrm{C} 12$ & $1.366(6)$ & $\mathrm{C} 23-\mathrm{H} 23$ & 0.9300 \\
\hline $\mathrm{C} 11-\mathrm{H} 11$ & 0.9300 & $\mathrm{~N} 1-\mathrm{N} 2$ & $1.410(2)$ \\
\hline $\mathrm{C} 12-\mathrm{C} 13$ & $1.362(6)$ & $\mathrm{N} 3-\mathrm{H} 24$ & 0.8600 \\
\hline $\mathrm{C} 12-\mathrm{H} 12$ & 0.9300 & & \\
\hline $\mathrm{N} 1-\mathrm{C} 1-\mathrm{C} 2$ & $121.53(18)$ & $\mathrm{C} 12-\mathrm{C} 13-\mathrm{H} 13$ & 120.3 \\
\hline $\mathrm{N} 1-\mathrm{C} 1-\mathrm{C} 8$ & $119.90(17)$ & $\mathrm{C} 14-\mathrm{C} 13-\mathrm{H} 13$ & 120.3 \\
\hline $\mathrm{C} 2-\mathrm{C} 1-\mathrm{C} 8$ & $118.45(16)$ & $\mathrm{C} 9-\mathrm{C} 14-\mathrm{C} 13$ & $120.3(3)$ \\
\hline $\mathrm{C} 3-\mathrm{C} 2-\mathrm{C} 7$ & $118.4(2)$ & $\mathrm{C} 9-\mathrm{C} 14-\mathrm{H} 14$ & 119.9 \\
\hline $\mathrm{C} 3-\mathrm{C} 2-\mathrm{C} 1$ & $120.79(19)$ & $\mathrm{C} 13-\mathrm{C} 14-\mathrm{H} 14$ & 119.9 \\
\hline $\mathrm{C} 7-\mathrm{C} 2-\mathrm{C} 1$ & $120.79(19)$ & $\mathrm{N} 2-\mathrm{C} 15-\mathrm{C} 16$ & $121.61(18)$ \\
\hline $\mathrm{C} 4-\mathrm{C} 3-\mathrm{C} 2$ & $120.3(2)$ & $\mathrm{N} 2-\mathrm{C} 15-\mathrm{H} 15$ & 119.2 \\
\hline $\mathrm{C} 4-\mathrm{C} 3-\mathrm{H} 3$ & 119.8 & $\mathrm{C} 16-\mathrm{C} 15-\mathrm{H} 15$ & 119.2 \\
\hline $\mathrm{C} 2-\mathrm{C} 3-\mathrm{H} 3$ & 119.8 & $\mathrm{C} 23-\mathrm{C} 16-\mathrm{C} 15$ & $123.68(18)$ \\
\hline $\mathrm{C} 5-\mathrm{C} 4-\mathrm{C} 3$ & $120.7(3)$ & $\mathrm{C} 23-\mathrm{C} 16-\mathrm{C} 17$ & $106.22(17)$ \\
\hline $\mathrm{C} 5-\mathrm{C} 4-\mathrm{H} 4$ & 119.7 & $\mathrm{C} 15-\mathrm{C} 16-\mathrm{C} 17$ & $129.90(17)$ \\
\hline $\mathrm{C} 3-\mathrm{C} 4-\mathrm{H} 4$ & 119.7 & $\mathrm{C} 18-\mathrm{C} 17-\mathrm{C} 22$ & $118.56(18)$ \\
\hline $\mathrm{C} 6-\mathrm{C} 5-\mathrm{C} 4$ & $119.8(3)$ & $\mathrm{C} 18-\mathrm{C} 17-\mathrm{C} 16$ & $135.04(18)$ \\
\hline $\mathrm{C} 6-\mathrm{C} 5-\mathrm{H} 5$ & 120.1 & $\mathrm{C} 22-\mathrm{C} 17-\mathrm{C} 16$ & $106.40(17)$ \\
\hline $\mathrm{C} 4-\mathrm{C} 5-\mathrm{H} 5$ & 120.1 & $\mathrm{C} 19-\mathrm{C} 18-\mathrm{C} 17$ & $119.0(2)$ \\
\hline $\mathrm{C} 5-\mathrm{C} 6-\mathrm{C} 7$ & $120.3(3)$ & $\mathrm{C} 19-\mathrm{C} 18-\mathrm{H} 18$ & 120.5 \\
\hline $\mathrm{C} 5-\mathrm{C} 6-\mathrm{H} 6$ & 119.8 & $\mathrm{C} 17-\mathrm{C} 18-\mathrm{H} 18$ & 120.5 \\
\hline $\mathrm{C} 7-\mathrm{C} 6-\mathrm{H} 6$ & 119.8 & $\mathrm{C} 18-\mathrm{C} 19-\mathrm{C} 20$ & $121.3(2)$ \\
\hline $\mathrm{C} 6-\mathrm{C} 7-\mathrm{C} 2$ & $120.5(2)$ & $\mathrm{C} 18-\mathrm{C} 19-\mathrm{H} 19$ & 119.4 \\
\hline $\mathrm{C} 6-\mathrm{C} 7-\mathrm{H} 7$ & 119.8 & $\mathrm{C} 20-\mathrm{C} 19-\mathrm{H} 19$ & 119.4 \\
\hline $\mathrm{C} 2-\mathrm{C} 7-\mathrm{H} 7$ & 119.8 & $\mathrm{C} 21-\mathrm{C} 20-\mathrm{C} 19$ & $121.3(2)$ \\
\hline $\mathrm{O} 1-\mathrm{C} 8-\mathrm{C} 9$ & $122.64(19)$ & $\mathrm{C} 21-\mathrm{C} 20-\mathrm{H} 20$ & 119.4 \\
\hline $\mathrm{O} 1-\mathrm{C} 8-\mathrm{C} 1$ & $119.01(18)$ & $\mathrm{C} 19-\mathrm{C} 20-\mathrm{H} 20$ & 119.4 \\
\hline $\mathrm{C} 9-\mathrm{C} 8-\mathrm{C} 1$ & $118.33(17)$ & $\mathrm{C} 20-\mathrm{C} 21-\mathrm{C} 22$ & $117.5(2)$ \\
\hline $\mathrm{C} 14-\mathrm{C} 9-\mathrm{C} 10$ & $119.9(2)$ & $\mathrm{C} 20-\mathrm{C} 21-\mathrm{H} 21$ & 121.2 \\
\hline $\mathrm{C} 14-\mathrm{C} 9-\mathrm{C} 8$ & $121.4(2)$ & $\mathrm{C} 22-\mathrm{C} 21-\mathrm{H} 21$ & 121.2 \\
\hline $\mathrm{C} 10-\mathrm{C} 9-\mathrm{C} 8$ & $118.7(2)$ & $\mathrm{N} 3-\mathrm{C} 22-\mathrm{C} 21$ & $130.1(2)$ \\
\hline $\mathrm{C} 11-\mathrm{C} 10-\mathrm{C} 9$ & $119.0(3)$ & $\mathrm{N} 3-\mathrm{C} 22-\mathrm{C} 17$ & $107.56(18)$ \\
\hline
\end{tabular}




$\begin{array}{llll}\mathrm{C} 11-\mathrm{C} 10-\mathrm{H} 10 & 120.5 & \mathrm{C} 21-\mathrm{C} 22-\mathrm{C} 17 & 122.37(19) \\ \mathrm{C} 9-\mathrm{C} 10-\mathrm{H} 10 & 120.5 & \mathrm{~N} 3-\mathrm{C} 23-\mathrm{C} 16 & 110.04(18) \\ \mathrm{C} 12-\mathrm{C} 11-\mathrm{C} 10 & 120.7(4) & \mathrm{N} 3-\mathrm{C} 23-\mathrm{H} 23 & 125.0 \\ \mathrm{C} 12-\mathrm{C} 11-\mathrm{H} 11 & 119.7 & \mathrm{C} 16-\mathrm{C} 23-\mathrm{H} 23 & 125.0 \\ \mathrm{C} 10-\mathrm{C} 11-\mathrm{H} 11 & 119.7 & \mathrm{C} 1-\mathrm{N} 1-\mathrm{N} 2 & 110.30(16) \\ \mathrm{C} 13-\mathrm{C} 12-\mathrm{C} 11 & 120.7(3) & \mathrm{C} 15-\mathrm{N} 2-\mathrm{N} 1 & 112.19(16) \\ \mathrm{C} 13-\mathrm{C} 12-\mathrm{H} 12 & 119.7 & \mathrm{C} 23-\mathrm{N} 3-\mathrm{C} 22 & 109.78(17) \\ \mathrm{C} 11-\mathrm{C} 12-\mathrm{H} 12 & 119.7 & \mathrm{C} 23-\mathrm{N} 3-\mathrm{H} 24 & 125.1 \\ \mathrm{C} 12-\mathrm{C} 13-\mathrm{C} 14 & 119.4(4) & \mathrm{C} 22-\mathrm{N} 3-\mathrm{H} 24 & 125.1\end{array}$

Hydrogen-bond geometry $\left(A,{ }^{\circ}\right)$

\begin{tabular}{lllll}
\hline$D-\mathrm{H} \cdots A$ & $D-\mathrm{H}$ & $\mathrm{H} \cdots A$ & $D \cdots A$ & $D-\mathrm{H} \cdots A$ \\
\hline $\mathrm{C} 3-\mathrm{H} 3 \cdots \mathrm{O}^{\mathrm{i}}$ & 0.93 & 2.55 & $3.413(3)$ & 154 \\
$\mathrm{~N} 3-\mathrm{H} 24 \cdots \mathrm{O} 1^{\mathrm{ii}}$ & 0.86 & 2.17 & $2.927(2)$ & 146 \\
\hline
\end{tabular}

Symmetry codes: (i) $x+1, y, z$; (ii) $x+1 / 2,-y+1 / 2,-z+2$.

(Z)-2-\{(E)-[1-(1H-Indol-3-yl)ethylidene]hydrazinylidene\}-\1,2-diphenylethanone (6-BMHAI)

\section{Crystal data}

$\mathrm{C}_{24} \mathrm{H}_{19} \mathrm{~N}_{3} \mathrm{O}$

$M_{r}=365.42$

Tetragonal, $P_{3} 2_{1} 2$

$a=8.3580(1) \AA$

$c=54.6705(7) \AA$

$V=3819.07(10) \AA^{3}$

$Z=8$

$F(000)=1536$

Data collection

Bruker SMART CCD area detector diffractometer

Radiation source: fine-focus sealed tube Detector resolution: 10.32 pixels $\mathrm{mm}^{-1}$ phi and $\omega$ scans

Absorption correction: multi-scan

(SADABS; Bruker, 2000)

$T_{\min }=0.983, T_{\max }=0.998$

\section{Refinement}

Refinement on $F^{2}$

Least-squares matrix: full

$R\left[F^{2}>2 \sigma\left(F^{2}\right)\right]=0.041$

$w R\left(F^{2}\right)=0.113$

$S=1.06$

3759 reflections

274 parameters

0 restraints

Hydrogen site location: inferred from neighbouring sites

Only $\mathrm{H}$-atom displacement parameters refined $w=1 /\left[\sigma^{2}\left(F_{\mathrm{o}}^{2}\right)+(0.0638 P)^{2}+0.5669 P\right]$

where $P=\left(F_{\mathrm{o}}^{2}+2 F_{\mathrm{c}}{ }^{2}\right) / 3$
$D_{\mathrm{x}}=1.271 \mathrm{Mg} \mathrm{m}^{-3}$

Mo $K \alpha$ radiation, $\lambda=0.71073 \AA$

Cell parameters from 380 reflections

$\theta=2.5-26.0^{\circ}$

$\mu=0.08 \mathrm{~mm}^{-1}$

$T=293 \mathrm{~K}$

Needle, yellow

$0.3 \times 0.1 \times 0.1 \mathrm{~mm}$

21746 measured reflections 3759 independent reflections 3565 reflections with $I>2 \sigma(I)$

$R_{\text {int }}=0.030$

$\theta_{\text {max }}=26.0^{\circ}, \theta_{\min }=1.5^{\circ}$

$h=-6 \rightarrow 10$

$k=-9 \rightarrow 9$

$l=-66 \rightarrow 66$

$(\Delta / \sigma)_{\max }<0.001$

$\Delta \rho_{\text {max }}=0.16$ e $\AA^{-3}$

$\Delta \rho_{\min }=-0.12$ e $\AA^{-3}$

Extinction correction: SHELXL2016

(Sheldrick, 2015b),

$\mathrm{Fc}^{*}=\mathrm{kFc}\left[1+0.001 \mathrm{xFc}^{2} \lambda^{3} / \sin (2 \theta)\right]^{-1 / 4}$

Extinction coefficient: 0.0060 (10)

Absolute structure: Flack $x$ determined using 1258 quotients $[(\mathrm{I}+)-(\mathrm{I}-)] /[(\mathrm{I}+)+(\mathrm{I}-)]$ (Parsons et al., 2013)

The diffraction data did not permit a clear determination of the absolute structure.

Absolute structure parameter: -1.5 (6) 


\section{Special details}

Geometry. All esds (except the esd in the dihedral angle between two 1.s. planes) are estimated using the full covariance matrix. The cell esds are taken into account individually in the estimation of esds in distances, angles and torsion angles; correlations between esds in cell parameters are only used when they are defined by crystal symmetry. An approximate (isotropic) treatment of cell esds is used for estimating esds involving l.s. planes.

Refinement. Refinement of $\mathrm{F}^{2}$ against ALL reflections. The weighted R-factor $\mathrm{wR}$ and goodness of fit $\mathrm{S}$ are based on $\mathrm{F}^{2}$, conventional $R$-factors $R$ are based on $F$, with $F$ set to zero for negative $F^{2}$. The threshold expression of $F^{2}>2 \operatorname{sigma}\left(\mathrm{F}^{2}\right)$ is used only for calculating R-factors(gt) etc. and is not relevant to the choice of reflections for refinement. R-factors based on $\mathrm{F}^{2}$ are statistically about twice as large as those based on F, and R- factors based on ALL data will be even larger.

Fractional atomic coordinates and isotropic or equivalent isotropic displacement parameters $\left(\AA^{2}\right)$

\begin{tabular}{|c|c|c|c|c|}
\hline & $x$ & $y$ & $z$ & $U_{\text {iso }} * / U_{\text {eq }}$ \\
\hline $\mathrm{C} 1$ & $1.1474(3)$ & $0.3991(2)$ & $0.03774(4)$ & $0.0375(4)$ \\
\hline $\mathrm{C} 2$ & $1.0797(3)$ & $0.4604(2)$ & $0.01468(4)$ & $0.0399(5)$ \\
\hline $\mathrm{C} 3$ & $1.1757(3)$ & $0.5262(3)$ & $-0.00339(4)$ & $0.0536(6)$ \\
\hline $\mathrm{H} 3$ & 1.285832 & 0.530978 & -0.001107 & $0.093(11)^{*}$ \\
\hline $\mathrm{C} 4$ & $1.1095(4)$ & $0.5845(4)$ & $-0.02472(4)$ & $0.0638(7)$ \\
\hline $\mathrm{H} 4$ & 1.175243 & 0.629370 & -0.036611 & $0.085(10)^{*}$ \\
\hline $\mathrm{C} 5$ & $0.9483(4)$ & $0.5770(4)$ & $-0.02850(5)$ & $0.0702(8)$ \\
\hline H5 & 0.904020 & 0.618015 & -0.042792 & $0.112(13)^{*}$ \\
\hline C6 & $0.8528(4)$ & $0.5092(5)$ & $-0.01127(6)$ & $0.0887(12)$ \\
\hline H6 & 0.743289 & 0.501715 & -0.014035 & $0.134(16)^{*}$ \\
\hline $\mathrm{C} 7$ & $0.9165(3)$ & $0.4509(4)$ & $0.01037(5)$ & $0.0688(8)$ \\
\hline $\mathrm{H} 7$ & 0.849569 & 0.405348 & 0.022041 & $0.080(10)^{*}$ \\
\hline $\mathrm{C} 8$ & 1.0347 (3) & $0.3189(2)$ & $0.05573(3)$ & $0.0357(4)$ \\
\hline C9 & $1.0165(3)$ & $0.1422(3)$ & $0.05565(4)$ & $0.0385(5)$ \\
\hline $\mathrm{C} 10$ & $0.9186(3)$ & $0.0725(3)$ & $0.07313(4)$ & $0.0485(6)$ \\
\hline H10 & 0.865994 & 0.135854 & 0.084567 & $0.064(9)^{*}$ \\
\hline C11 & $0.8998(4)$ & $-0.0923(3)$ & $0.07344(5)$ & $0.0639(7)$ \\
\hline H11 & 0.834722 & -0.139926 & 0.085166 & $0.107(13)^{*}$ \\
\hline $\mathrm{C} 12$ & $0.9768(4)$ & -0.1849 (3) & $0.05651(6)$ & $0.0740(9)$ \\
\hline H12 & 0.963375 & -0.295330 & 0.056759 & $0.110(13)^{*}$ \\
\hline $\mathrm{C} 13$ & $1.0735(4)$ & $-0.1166(3)$ & $0.03917(7)$ & $0.0765(9)$ \\
\hline H13 & 1.125833 & -0.180829 & 0.027809 & $0.097(12)^{*}$ \\
\hline $\mathrm{C} 14$ & $1.0937(3)$ & $0.0485(3)$ & $0.03852(5)$ & $0.0565(6)$ \\
\hline H14 & 1.158469 & 0.095295 & 0.026686 & $0.061(8)^{*}$ \\
\hline $\mathrm{C} 15$ & $1.4732(2)$ & $0.3899(3)$ & $0.07414(4)$ & $0.0394(5)$ \\
\hline $\mathrm{C} 16$ & $1.5313(2)$ & 0.2955 & $0.09468(4)$ & $0.0396(5)$ \\
\hline $\mathrm{C} 17$ & $1.4917(2)$ & $0.1302(3)$ & $0.09979(4)$ & $0.0383(5)$ \\
\hline $\mathrm{C} 18$ & $1.3983(3)$ & 0.0148 & $0.08826(4)$ & $0.0462(5)$ \\
\hline H18 & 1.342170 & 0.039309 & 0.074057 & $0.064(8)^{*}$ \\
\hline C19 & $1.3903(4)$ & -0.1359 & $0.09820(5)$ & $0.0614(7)$ \\
\hline H19 & 1.327760 & -0.213486 & 0.090633 & $0.071(9)^{*}$ \\
\hline $\mathrm{C} 20$ & $1.4748(5)$ & -0.1750 & $0.11958(5)$ & $0.0710(9)$ \\
\hline $\mathrm{H} 20$ & 1.467785 & -0.278356 & 0.125807 & $0.094(11)^{*}$ \\
\hline $\mathrm{C} 21$ & $1.5667(4)$ & -0.0651 & $0.13138(5)$ & $0.0661(8)$ \\
\hline H21 & 1.622214 & -0.091123 & 0.145572 & $0.097(12)^{*}$ \\
\hline
\end{tabular}




$\begin{array}{lllll}\mathrm{C} 22 & 1.5744(3) & 0.0886(3) & 0.12134(4) & 0.0487(6) \\ \mathrm{C} 23 & 1.6341(3) & 0.3418(3) & 0.11298(5) & 0.0534(6) \\ \mathrm{H} 23 & 1.679950 & 0.442841 & 0.114289 & 0.073(9)^{*} \\ \mathrm{C} 24 & 1.5707(3) & 0.5277(3) & 0.06510(5) & 0.0569(7) \\ \mathrm{H} 24 \mathrm{~A} & 1.667158 & 0.535719 & 0.074549 & 0.156(19)^{*} \\ \mathrm{H} 24 \mathrm{~B} & 1.510208 & 0.624774 & 0.066728 & 0.18(2)^{*} \\ \mathrm{H} 24 \mathrm{C} & 1.597308 & 0.511150 & 0.048203 & 0.121(15)^{*} \\ \mathrm{~N} 1 & 1.2956(2) & 0.4223(2) & 0.04307(3) & 0.0462(5) \\ \mathrm{N} 2 & 1.3383(2) & 0.3443(2) & 0.06501(3) & 0.0455(5) \\ \mathrm{N} 3 & 1.6592(3) & 0.2208(3) & 0.12874(4) & 0.0609(6) \\ \mathrm{H} 25 & 1.719109 & 0.225541 & 0.141506 & 0.074(10)^{*} \\ \mathrm{O} 1 & 0.9581(2) & 0.4039(2) & 0.06942(3) & 0.0527(4)\end{array}$

Atomic displacement parameters $\left(\AA^{2}\right)$

\begin{tabular}{|c|c|c|c|c|c|c|}
\hline & $U^{11}$ & $U^{22}$ & $U^{33}$ & $U^{12}$ & $U^{13}$ & $U^{23}$ \\
\hline $\mathrm{C} 1$ & $0.0424(11)$ & $0.0314(10)$ & $0.0386(10)$ & $0.0004(8)$ & $-0.0045(9)$ & $0.0036(8)$ \\
\hline $\mathrm{C} 2$ & $0.0495(12)$ & $0.0335(10)$ & $0.0367(10)$ & $0.0004(9)$ & $-0.0053(9)$ & $0.0043(8)$ \\
\hline $\mathrm{C} 3$ & $0.0571(15)$ & $0.0570(15)$ & $0.0468(12)$ & $-0.0025(11)$ & 0.0007 (11) & $0.0080(11)$ \\
\hline $\mathrm{C} 4$ & $0.085(2)$ & $0.0643(17)$ & $0.0427(12)$ & $-0.0019(15)$ & $0.0041(13)$ & $0.0151(12)$ \\
\hline $\mathrm{C} 5$ & $0.085(2)$ & $0.079(2)$ & $0.0462(13)$ & $0.0060(17)$ & $-0.0175(14)$ & $0.0186(13)$ \\
\hline C6 & $0.0621(19)$ & $0.136(4)$ & $0.0682(18)$ & $0.003(2)$ & $-0.0228(16)$ & $0.035(2)$ \\
\hline $\mathrm{C} 7$ & $0.0510(15)$ & $0.101(2)$ & $0.0540(14)$ & $-0.0045(15)$ & $-0.0100(12)$ & $0.0274(15)$ \\
\hline $\mathrm{C} 8$ & $0.0386(10)$ & $0.0359(10)$ & $0.0326(8)$ & $0.0017(8)$ & $-0.0067(8)$ & $0.0027(8)$ \\
\hline C9 & $0.0420(11)$ & $0.0354(10)$ & $0.0380(9)$ & $-0.0012(8)$ & $-0.0074(9)$ & $0.0031(8)$ \\
\hline $\mathrm{C} 10$ & $0.0533(13)$ & $0.0490(13)$ & $0.0433(11)$ & $-0.0057(10)$ & $-0.0038(10)$ & $0.0080(10)$ \\
\hline $\mathrm{C} 11$ & $0.0720(18)$ & $0.0547(15)$ & $0.0649(15)$ & $-0.0184(14)$ & $-0.0094(14)$ & $0.0209(13)$ \\
\hline $\mathrm{C} 12$ & $0.087(2)$ & $0.0362(14)$ & $0.098(2)$ & $-0.0104(14)$ & $-0.0130(19)$ & $0.0024(15)$ \\
\hline $\mathrm{C} 13$ & $0.090(2)$ & $0.0446(15)$ & $0.095(2)$ & $-0.0013(15)$ & $0.0128(19)$ & $-0.0203(15)$ \\
\hline C14 & $0.0642(16)$ & $0.0440(13)$ & $0.0614(14)$ & $-0.0059(12)$ & $0.0087(13)$ & $-0.0086(11)$ \\
\hline $\mathrm{C} 15$ & $0.0322(10)$ & $0.0393(11)$ & $0.0467(10)$ & $0.0002(8)$ & $-0.0004(9)$ & $0.0020(9)$ \\
\hline C16 & $0.0311(10)$ & $0.0456(12)$ & $0.0420(10)$ & $0.0012(9)$ & $-0.0029(9)$ & $0.0015(9)$ \\
\hline $\mathrm{C} 17$ & $0.0336(10)$ & $0.0460(12)$ & $0.0354(9)$ & $0.0072(8)$ & $0.0017(8)$ & $0.0040(8)$ \\
\hline $\mathrm{C} 18$ & $0.0480(12)$ & $0.0470(12)$ & $0.0437(11)$ & $-0.0002(10)$ & $0.0013(9)$ & $0.0032(9)$ \\
\hline C19 & $0.0777(19)$ & $0.0472(14)$ & $0.0593(14)$ & $-0.0006(13)$ & $0.0133(14)$ & $0.0079(12)$ \\
\hline $\mathrm{C} 20$ & $0.104(3)$ & $0.0494(15)$ & $0.0602(15)$ & $0.0214(16)$ & $0.0204(17)$ & $0.0186(13)$ \\
\hline $\mathrm{C} 21$ & $0.083(2)$ & $0.0711(19)$ & $0.0446(13)$ & $0.0318(16)$ & $0.0022(13)$ & $0.0160(13)$ \\
\hline $\mathrm{C} 22$ & $0.0447(13)$ & $0.0619(15)$ & $0.0395(11)$ & $0.0159(11)$ & $-0.0005(9)$ & $0.0034(10)$ \\
\hline $\mathrm{C} 23$ & $0.0412(13)$ & $0.0594(15)$ & $0.0597(13)$ & $-0.0011(11)$ & $-0.0118(11)$ & $-0.0079(12)$ \\
\hline $\mathrm{C} 24$ & $0.0482(14)$ & $0.0501(14)$ & $0.0723(17)$ & $-0.0120(12)$ & $0.0006(13)$ & $0.0104(13)$ \\
\hline N1 & $0.0433(10)$ & $0.0463(11)$ & $0.0489(10)$ & $-0.0053(8)$ & $-0.0090(8)$ & $0.0139(9)$ \\
\hline $\mathrm{N} 2$ & $0.0409(10)$ & $0.0468(11)$ & $0.0489(10)$ & $-0.0065(8)$ & $-0.0108(8)$ & $0.0144(8)$ \\
\hline N3 & $0.0518(12)$ & $0.0784(16)$ & $0.0525(11)$ & $0.0118(11)$ & $-0.0218(10)$ & $-0.0041(11)$ \\
\hline $\mathrm{O} 1$ & $0.0628(11)$ & $0.0440(9)$ & $0.0512(9)$ & $0.0070(8)$ & $0.0083(8)$ & $-0.0033(7)$ \\
\hline
\end{tabular}


Geometric parameters $\left(\AA,{ }^{\circ}\right)$

\begin{tabular}{|c|c|c|c|}
\hline $\mathrm{C} 1-\mathrm{N} 1$ & $1.287(3)$ & $\mathrm{C} 13-\mathrm{H} 13$ & 0.9300 \\
\hline $\mathrm{C} 1-\mathrm{C} 2$ & $1.474(3)$ & C14-H14 & 0.9300 \\
\hline $\mathrm{C} 1-\mathrm{C} 8$ & $1.518(3)$ & $\mathrm{C} 15-\mathrm{N} 2$ & $1.290(3)$ \\
\hline $\mathrm{C} 2-\mathrm{C} 3$ & $1.386(3)$ & $\mathrm{C} 15-\mathrm{C} 16$ & $1.456(3)$ \\
\hline $\mathrm{C} 2-\mathrm{C} 7$ & $1.386(4)$ & $\mathrm{C} 15-\mathrm{C} 24$ & $1.495(3)$ \\
\hline $\mathrm{C} 3-\mathrm{C} 4$ & $1.380(3)$ & $\mathrm{C} 16-\mathrm{C} 23$ & $1.375(3)$ \\
\hline $\mathrm{C} 3-\mathrm{H} 3$ & 0.9300 & $\mathrm{C} 16-\mathrm{C} 17$ & $1.448(3)$ \\
\hline $\mathrm{C} 4-\mathrm{C} 5$ & $1.365(4)$ & $\mathrm{C} 17-\mathrm{C} 18$ & $1.392(3)$ \\
\hline $\mathrm{C} 4-\mathrm{H} 4$ & 0.9300 & $\mathrm{C} 17-\mathrm{C} 22$ & $1.409(3)$ \\
\hline $\mathrm{C} 5-\mathrm{C} 6$ & $1.358(4)$ & $\mathrm{C} 18-\mathrm{C} 19$ & $1.373(3)$ \\
\hline $\mathrm{C} 5-\mathrm{H} 5$ & 0.9300 & C18-H18 & 0.9300 \\
\hline $\mathrm{C} 6-\mathrm{C} 7$ & $1.386(4)$ & $\mathrm{C} 19-\mathrm{C} 20$ & $1.404(4)$ \\
\hline $\mathrm{C} 6-\mathrm{H} 6$ & 0.9300 & C19-H19 & 0.9300 \\
\hline $\mathrm{C} 7-\mathrm{H} 7$ & 0.9300 & $\mathrm{C} 20-\mathrm{C} 21$ & $1.360(5)$ \\
\hline $\mathrm{C} 8-\mathrm{O} 1$ & $1.214(3)$ & $\mathrm{C} 20-\mathrm{H} 20$ & 0.9300 \\
\hline $\mathrm{C} 8-\mathrm{C} 9$ & $1.485(3)$ & $\mathrm{C} 21-\mathrm{C} 22$ & $1.399(4)$ \\
\hline $\mathrm{C} 9-\mathrm{C} 14$ & $1.381(3)$ & $\mathrm{C} 21-\mathrm{H} 21$ & 0.9300 \\
\hline $\mathrm{C} 9-\mathrm{C} 10$ & $1.386(3)$ & $\mathrm{C} 22-\mathrm{N} 3$ & $1.373(4)$ \\
\hline $\mathrm{C} 10-\mathrm{C} 11$ & $1.387(4)$ & $\mathrm{C} 23-\mathrm{N} 3$ & $1.345(4)$ \\
\hline $\mathrm{C} 10-\mathrm{H} 10$ & 0.9300 & $\mathrm{C} 23-\mathrm{H} 23$ & 0.9300 \\
\hline $\mathrm{C} 11-\mathrm{C} 12$ & $1.367(5)$ & $\mathrm{C} 24-\mathrm{H} 24 \mathrm{~A}$ & 0.9600 \\
\hline $\mathrm{C} 11-\mathrm{H} 11$ & 0.9300 & $\mathrm{C} 24-\mathrm{H} 24 \mathrm{~B}$ & 0.9600 \\
\hline $\mathrm{C} 12-\mathrm{C} 13$ & $1.370(5)$ & $\mathrm{C} 24-\mathrm{H} 24 \mathrm{C}$ & 0.9600 \\
\hline $\mathrm{C} 12-\mathrm{H} 12$ & 0.9300 & $\mathrm{~N} 1-\mathrm{N} 2$ & $1.411(2)$ \\
\hline $\mathrm{C} 13-\mathrm{C} 14$ & $1.391(4)$ & $\mathrm{N} 3-\mathrm{H} 25$ & 0.8600 \\
\hline $\mathrm{N} 1-\mathrm{C} 1-\mathrm{C} 2$ & $120.7(2)$ & $\mathrm{C} 9-\mathrm{C} 14-\mathrm{H} 14$ & 120.4 \\
\hline $\mathrm{N} 1-\mathrm{C} 1-\mathrm{C} 8$ & $121.11(18)$ & $\mathrm{C} 13-\mathrm{C} 14-\mathrm{H} 14$ & 120.4 \\
\hline $\mathrm{C} 2-\mathrm{C} 1-\mathrm{C} 8$ & $118.00(18)$ & $\mathrm{N} 2-\mathrm{C} 15-\mathrm{C} 16$ & $115.46(19)$ \\
\hline $\mathrm{C} 3-\mathrm{C} 2-\mathrm{C} 7$ & $118.1(2)$ & $\mathrm{N} 2-\mathrm{C} 15-\mathrm{C} 24$ & $125.1(2)$ \\
\hline $\mathrm{C} 3-\mathrm{C} 2-\mathrm{C} 1$ & $121.7(2)$ & $\mathrm{C} 16-\mathrm{C} 15-\mathrm{C} 24$ & $119.4(2)$ \\
\hline $\mathrm{C} 7-\mathrm{C} 2-\mathrm{C} 1$ & $120.2(2)$ & $\mathrm{C} 23-\mathrm{C} 16-\mathrm{C} 17$ & $105.7(2)$ \\
\hline $\mathrm{C} 4-\mathrm{C} 3-\mathrm{C} 2$ & $120.7(3)$ & $\mathrm{C} 23-\mathrm{C} 16-\mathrm{C} 15$ & $128.1(2)$ \\
\hline $\mathrm{C} 4-\mathrm{C} 3-\mathrm{H} 3$ & 119.7 & $\mathrm{C} 17-\mathrm{C} 16-\mathrm{C} 15$ & $126.14(19)$ \\
\hline $\mathrm{C} 2-\mathrm{C} 3-\mathrm{H} 3$ & 119.7 & $\mathrm{C} 18-\mathrm{C} 17-\mathrm{C} 22$ & $118.9(2)$ \\
\hline $\mathrm{C} 5-\mathrm{C} 4-\mathrm{C} 3$ & $120.5(3)$ & $\mathrm{C} 18-\mathrm{C} 17-\mathrm{C} 16$ & $134.59(19)$ \\
\hline $\mathrm{C} 5-\mathrm{C} 4-\mathrm{H} 4$ & 119.8 & $\mathrm{C} 22-\mathrm{C} 17-\mathrm{C} 16$ & $106.5(2)$ \\
\hline $\mathrm{C} 3-\mathrm{C} 4-\mathrm{H} 4$ & 119.8 & $\mathrm{C} 19-\mathrm{C} 18-\mathrm{C} 17$ & $118.9(2)$ \\
\hline $\mathrm{C} 6-\mathrm{C} 5-\mathrm{C} 4$ & $119.6(2)$ & $\mathrm{C} 19-\mathrm{C} 18-\mathrm{H} 18$ & 120.5 \\
\hline $\mathrm{C} 6-\mathrm{C} 5-\mathrm{H} 5$ & 120.2 & $\mathrm{C} 17-\mathrm{C} 18-\mathrm{H} 18$ & 120.5 \\
\hline $\mathrm{C} 4-\mathrm{C} 5-\mathrm{H} 5$ & 120.2 & $\mathrm{C} 18-\mathrm{C} 19-\mathrm{C} 20$ & $121.2(3)$ \\
\hline $\mathrm{C} 5-\mathrm{C} 6-\mathrm{C} 7$ & $120.9(3)$ & $\mathrm{C} 18-\mathrm{C} 19-\mathrm{H} 19$ & 119.4 \\
\hline $\mathrm{C} 5-\mathrm{C} 6-\mathrm{H} 6$ & 119.6 & $\mathrm{C} 20-\mathrm{C} 19-\mathrm{H} 19$ & 119.4 \\
\hline $\mathrm{C} 7-\mathrm{C} 6-\mathrm{H} 6$ & 119.6 & $\mathrm{C} 21-\mathrm{C} 20-\mathrm{C} 19$ & $121.4(3)$ \\
\hline $\mathrm{C} 6-\mathrm{C} 7-\mathrm{C} 2$ & $120.2(3)$ & $\mathrm{C} 21-\mathrm{C} 20-\mathrm{H} 20$ & 119.3 \\
\hline $\mathrm{C} 6-\mathrm{C} 7-\mathrm{H} 7$ & 119.9 & $\mathrm{C} 19-\mathrm{C} 20-\mathrm{H} 20$ & 119.3 \\
\hline
\end{tabular}




$\begin{array}{llll}\mathrm{C} 2-\mathrm{C} 7-\mathrm{H} 7 & 119.9 & \mathrm{C} 20-\mathrm{C} 21-\mathrm{C} 22 & 117.4(2) \\ \mathrm{O} 1-\mathrm{C} 8-\mathrm{C} 9 & 122.0(2) & \mathrm{C} 20-\mathrm{C} 21-\mathrm{H} 21 & 121.3 \\ \mathrm{O} 1-\mathrm{C} 8-\mathrm{C} 1 & 117.96(19) & \mathrm{C} 22-\mathrm{C} 21-\mathrm{H} 21 & 121.3 \\ \mathrm{C} 9-\mathrm{C} 8-\mathrm{C} 1 & 120.03(18) & \mathrm{N} 3-\mathrm{C} 22-\mathrm{C} 21 & 130.3(2) \\ \mathrm{C} 14-\mathrm{C} 9-\mathrm{C} 10 & 120.3(2) & \mathrm{N} 3-\mathrm{C} 22-\mathrm{C} 17 & 107.5(2) \\ \mathrm{C} 14-\mathrm{C} 9-\mathrm{C} 8 & 121.2(2) & \mathrm{C} 21-\mathrm{C} 22-\mathrm{C} 17 & 122.1(3) \\ \mathrm{C} 10-\mathrm{C} 9-\mathrm{C} 8 & 118.4(2) & \mathrm{N} 3-\mathrm{C} 23-\mathrm{C} 16 & 110.6(2) \\ \mathrm{C} 9-\mathrm{C} 10-\mathrm{C} 11 & 119.5(3) & \mathrm{N} 3-\mathrm{C} 23-\mathrm{H} 23 & 124.7 \\ \mathrm{C} 9-\mathrm{C} 10-\mathrm{H} 10 & 120.2 & \mathrm{C} 16-\mathrm{C} 23-\mathrm{H} 23 & 124.7 \\ \mathrm{C} 11-\mathrm{C} 10-\mathrm{H} 10 & 120.2 & \mathrm{C} 15-\mathrm{C} 24-\mathrm{H} 24 \mathrm{~A} & 109.5 \\ \mathrm{C} 12-\mathrm{C} 11-\mathrm{C} 10 & 120.0(3) & \mathrm{C} 15-\mathrm{C} 24-\mathrm{H} 24 \mathrm{~B} & 109.5 \\ \mathrm{C} 12-\mathrm{C} 11-\mathrm{H} 11 & 120.0 & \mathrm{H} 24 \mathrm{~A}-\mathrm{C} 24-\mathrm{H} 24 \mathrm{~B} & 109.5 \\ \mathrm{C} 10-\mathrm{C} 11-\mathrm{H} 11 & 120.0 & \mathrm{C} 15-\mathrm{C} 24-\mathrm{H} 24 \mathrm{C} & 109.5 \\ \mathrm{C} 11-\mathrm{C} 12-\mathrm{C} 13 & 120.7(2) & \mathrm{H} 24 \mathrm{~A}-\mathrm{C} 24-\mathrm{H} 24 \mathrm{C} & 109.5 \\ \mathrm{C} 11-\mathrm{C} 12-\mathrm{H} 12 & 119.7 & \mathrm{H} 24 \mathrm{~B}-\mathrm{C} 24-\mathrm{H} 24 \mathrm{C} & 109.5 \\ \mathrm{C} 13-\mathrm{C} 12-\mathrm{H} 12 & \mathrm{C} 1-\mathrm{N} 1-\mathrm{N} 2 & 111.51(18) \\ \mathrm{C} 12-\mathrm{C} 13-\mathrm{C} 14 & 119.7 & \mathrm{C} 15-\mathrm{N} 2-\mathrm{N} 1 & 114.44(18) \\ \mathrm{C} 12-\mathrm{C} 13-\mathrm{H} 13 & 120.1(3) & \mathrm{C} 23-\mathrm{N} 3-\mathrm{C} 22 & 109.6(2) \\ \mathrm{C} 14-\mathrm{C} 13-\mathrm{H} 13 & 119.9 & \mathrm{C} 23-\mathrm{N} 3-\mathrm{H} 25 & 125.2 \\ \mathrm{C} 9-\mathrm{C} 14-\mathrm{C} 13 & 119.9 & \mathrm{C} 22-\mathrm{N} 3-\mathrm{H} 25 & 125.2\end{array}$

Hydrogen-bond geometry $\left(\AA,{ }^{\circ}\right)$

\begin{tabular}{lllll}
\hline$D-\mathrm{H} \cdots A$ & $D-\mathrm{H}$ & $\mathrm{H} \cdots A$ & $D \cdots A$ & $D-\mathrm{H} \cdots A$ \\
\hline $\mathrm{C} 18-\mathrm{H} 18 \cdots \mathrm{N} 2$ & 0.93 & 2.60 & $3.074(3)$ & 112 \\
\hline
\end{tabular}

$\backslash(Z)-2-\{(E)$-[(1-Methyl-1H-indol-3-yl) \methylidene]hydrazinylidene\}-1,2-diphenylethanone (7-BMHMFI)

Crystal data

$\mathrm{C}_{24} \mathrm{H}_{19} \mathrm{~N}_{3} \mathrm{O}$

$M_{r}=365.42$

Monoclinic, $P 2{ }_{1} / c$

$a=18.6779(6) \AA$

$b=8.6694(3) \AA$

$c=12.7956(4) \AA$

$\beta=106.910(4)^{\circ}$

$V=1982.36(12) \AA^{3}$

$Z=4$

\section{Data collection}

Bruker SMART CCD area detector diffractometer

Radiation source: fine-focus sealed tube Detector resolution: 10.11 pixels $\mathrm{mm}^{-1}$

phi and $\omega$ scans

Absorption correction: multi-scan

(SADABS; Bruker, 2000)

$T_{\min }=0.971, T_{\max }=0.987$
$F(000)=768$

$D_{\mathrm{x}}=1.224 \mathrm{Mg} \mathrm{m}^{-3}$

Mo $K \alpha$ radiation, $\lambda=0.71073 \AA$

Cell parameters from 380 reflections

$\theta=2.5-26.0^{\circ}$

$\mu=0.08 \mathrm{~mm}^{-1}$

$T=293 \mathrm{~K}$

Block, yellow

$0.33 \times 0.28 \times 0.25 \mathrm{~mm}$

9410 measured reflections

3837 independent reflections

2964 reflections with $I>2 \sigma(I)$

$R_{\text {int }}=0.021$

$\theta_{\text {max }}=26.1^{\circ}, \theta_{\text {min }}=2.3^{\circ}$

$h=-14 \rightarrow 22$

$k=-10 \rightarrow 10$

$l=-15 \rightarrow 15$ 


\section{Refinement}

Refinement on $F^{2}$

Least-squares matrix: full

$R\left[F^{2}>2 \sigma\left(F^{2}\right)\right]=0.045$

$w R\left(F^{2}\right)=0.140$

$S=1.03$

3837 reflections

274 parameters

0 restraints

Hydrogen site location: inferred from neighbouring sites
Only $\mathrm{H}$-atom displacement parameters refined

$w=1 /\left[\sigma^{2}\left(F_{\mathrm{o}}^{2}\right)+(0.0721 P)^{2}+0.203 P\right]$ where $P=\left(F_{\mathrm{o}}{ }^{2}+2 F_{\mathrm{c}}{ }^{2}\right) / 3$

$(\Delta / \sigma)_{\max }<0.001$

$\Delta \rho_{\max }=0.16 \mathrm{e} \AA^{-3}$

$\Delta \rho_{\min }=-0.15$ e $\AA^{-3}$

Extinction correction: SHELXL2016 (Sheldrick, 2015b), $\mathrm{Fc}^{*}=\mathrm{kFc}\left[1+0.001 \mathrm{xFc}^{2} \lambda^{3} / \sin (2 \theta)\right]^{-1 / 4}$

Extinction coefficient: 0.0045 (13)

Special details

Geometry. All esds (except the esd in the dihedral angle between two 1.s. planes) are estimated using the full covariance matrix. The cell esds are taken into account individually in the estimation of esds in distances, angles and torsion angles; correlations between esds in cell parameters are only used when they are defined by crystal symmetry. An approximate (isotropic) treatment of cell esds is used for estimating esds involving l.s. planes.

Refinement. Refinement of $\mathrm{F}^{2}$ against ALL reflections. The weighted R-factor $\mathrm{wR}$ and goodness of fit $\mathrm{S}$ are based on $\mathrm{F}^{2}$, conventional R-factors $R$ are based on $F$, with $F$ set to zero for negative $F^{2}$. The threshold expression of $\mathrm{F}^{2}>2 \operatorname{sigma}\left(\mathrm{F}^{2}\right)$ is used only for calculating R-factors(gt) etc. and is not relevant to the choice of reflections for refinement. R-factors based on $\mathrm{F}^{2}$ are statistically about twice as large as those based on F, and R- factors based on ALL data will be even larger.

Fractional atomic coordinates and isotropic or equivalent isotropic displacement parameters $\left(\AA^{2}\right)$

\begin{tabular}{|c|c|c|c|c|}
\hline & $x$ & $y$ & $z$ & $U_{\text {iso }} * / U_{\text {eq }}$ \\
\hline $\mathrm{C} 1$ & $0.80896(9)$ & $0.5549(2)$ & $0.27473(14)$ & $0.0584(4)$ \\
\hline $\mathrm{C} 2$ & $0.88286(10)$ & $0.6191(2)$ & $0.33323(15)$ & $0.0659(4)$ \\
\hline $\mathrm{C} 3$ & $0.89301(12)$ & $0.7045(3)$ & $0.42794(18)$ & $0.0837(6)$ \\
\hline $\mathrm{H} 3$ & 0.852945 & 0.720693 & 0.455994 & $0.075(6)^{*}$ \\
\hline $\mathrm{C} 4$ & $0.96264(15)$ & $0.7658(4)$ & $0.4811(2)$ & $0.1081(9)$ \\
\hline $\mathrm{H} 4$ & 0.969070 & 0.823302 & 0.544526 & $0.120(10)^{*}$ \\
\hline $\mathrm{C} 5$ & $1.02223(14)$ & $0.7419(4)$ & $0.4403(3)$ & $0.1200(11)$ \\
\hline H5 & 1.068774 & 0.784014 & 0.475643 & $0.125(10)^{*}$ \\
\hline C6 & $1.01287(14)$ & $0.6567(5)$ & 0.3485 & $0.1234(11)$ \\
\hline H6 & 1.053354 & 0.639808 & 0.321499 & $0.134(11)^{*}$ \\
\hline $\mathrm{C} 7$ & $0.94374(11)$ & $0.5945(3)$ & $0.2945(2)$ & $0.0953(7)$ \\
\hline $\mathrm{H} 7$ & 0.938221 & 0.535900 & 0.231818 & $0.099(8) *$ \\
\hline $\mathrm{C} 8$ & $0.79924(9)$ & $0.4658(2)$ & $0.16966(14)$ & 0.0603 (4) \\
\hline C9 & $0.79785(8)$ & $0.2948(2)$ & $0.17403(13)$ & $0.0576(4)$ \\
\hline $\mathrm{C} 10$ & $0.77856(11)$ & $0.2110(3)$ & $0.07773(17)$ & $0.0757(5)$ \\
\hline H10 & 0.766790 & 0.261502 & 0.010761 & $0.083(6)^{*}$ \\
\hline C11 & $0.77691(13)$ & $0.0510(3)$ & $0.0818(2)$ & $0.0955(7)$ \\
\hline H11 & 0.763005 & -0.005355 & 0.017221 & $0.120(9)^{*}$ \\
\hline $\mathrm{C} 12$ & $0.79548(14)$ & $-0.0243(3)$ & $0.1796(3)$ & $0.1008(8)$ \\
\hline H12 & 0.795084 & -0.131493 & 0.181433 & $0.128(10)^{*}$ \\
\hline $\mathrm{C} 13$ & $0.81477(13)$ & $0.0581(3)$ & $0.2755(2)$ & $0.0891(6)$ \\
\hline H13 & 0.827294 & 0.006791 & 0.342203 & $0.111(9)^{*}$ \\
\hline $\mathrm{C} 14$ & $0.81552(10)$ & $0.2171(2)$ & $0.27258(16)$ & $0.0679(5)$ \\
\hline H14 & 0.828040 & 0.272649 & 0.337583 & $0.073(6)^{*}$ \\
\hline $\mathrm{C} 15$ & $0.62962(9)$ & $0.54270(18)$ & $0.27528(13)$ & $0.0556(4)$ \\
\hline
\end{tabular}




$\begin{array}{lllll}\text { H15 } & 0.635990 & 0.605392 & 0.336293 & 0.060(5)^{*} \\ \text { C16 } & 0.55620(8) & 0.48955(17) & 0.21907(12) & 0.0496(3) \\ \text { C17 } & 0.53199(9) & 0.38820(16) & 0.12688(12) & 0.0487(3) \\ \text { C18 } & 0.56873(10) & 0.29923(18) & 0.06710(14) & 0.0592(4) \\ \text { H18 } & 0.620638 & 0.300348 & 0.083982 & 0.067(5)^{*} \\ \text { C19 } & 0.52650(13) & 0.2104(2) & -0.01693(15) & 0.0733(5) \\ \text { H19 } & 0.550354 & 0.149515 & -0.056525 & 0.095(7)^{*} \\ \text { C20 } & 0.44874(13) & 0.2091(2) & -0.04436(15) & 0.0771(6) \\ \text { H20 } & 0.421868 & 0.148219 & -0.102360 & 0.085(6)^{*} \\ \text { C21 } & 0.41058(11) & 0.2957(2) & 0.01205(13) & 0.0644(4) \\ \text { H21 } & 0.358599 & 0.295302 & -0.006658 & 0.068(5)^{*} \\ \text { C22 } & 0.45351(9) & 0.38363(17) & 0.09833(12) & 0.0522(4) \\ \text { C23 } & 0.49247(9) & 0.53965(19) & 0.24184(13) & 0.0556(4) \\ \text { H23 } & 0.491806 & 0.606454 & 0.298423 & 0.071(5)^{*} \\ \text { C24 } & 0.35385(10) & 0.5102(3) & 0.16663(19) & 0.0815(6) \\ \text { H24A } & 0.331755 & 0.419249 & 0.186891 & 0.139(11)^{*} \\ \text { H24B } & 0.326182 & 0.540419 & 0.093916 & 0.117(9)^{*} \\ \text { H24C } & 0.352681 & 0.592153 & 0.216577 & 0.136(11)^{*} \\ \text { N1 } & 0.75252(8) & 0.57812(18) & 0.31109(12) & 0.0640(4) \\ \text { N2 } & 0.68730(7) & 0.50715(17) & 0.24473(12) & 0.0591(3) \\ \text { N3 } & 0.43088(7) & 0.47817(16) & 0.17043(11) & 0.0557(3) \\ \text { O1 } & 0.79386(9) & 0.53693(19) & 0.08597(11) & 0.0846(4)\end{array}$

Atomic displacement parameters $\left(\AA^{2}\right)$

\begin{tabular}{lllllll}
\hline & $U^{11}$ & $U^{22}$ & $U^{33}$ & $U^{12}$ & $U^{13}$ & $U^{23}$ \\
\hline C1 & $0.0518(8)$ & $0.0596(9)$ & $0.0633(9)$ & $0.0000(7)$ & $0.0160(7)$ & $0.0068(7)$ \\
C2 & $0.0539(9)$ & $0.0692(10)$ & $0.0702(10)$ & $-0.0027(8)$ & $0.0113(8)$ & $0.0106(9)$ \\
C3 & $0.0734(12)$ & $0.0917(15)$ & $0.0820(13)$ & $-0.0150(11)$ & $0.0162(10)$ & $-0.0051(11)$ \\
C4 & $0.0916(17)$ & $0.123(2)$ & $0.0935(17)$ & $-0.0272(16)$ & $0.0017(13)$ & $-0.0131(16)$ \\
C5 & $0.0637(14)$ & $0.161(3)$ & $0.119(2)$ & $-0.0317(16)$ & $0.0000(14)$ & $-0.005(2)$ \\
C6 & $0.0605(13)$ & $0.184(3)$ & $0.125(2)$ & $-0.0248(17)$ & $0.0246(14)$ & $-0.014(2)$ \\
C7 & $0.0583(11)$ & $0.132(2)$ & $0.0959(16)$ & $-0.0114(12)$ & $0.0230(11)$ & $-0.0120(15)$ \\
C8 & $0.0471(8)$ & $0.0759(11)$ & $0.0583(9)$ & $0.0023(7)$ & $0.0157(7)$ & $0.0095(8)$ \\
C9 & $0.0421(7)$ & $0.0717(10)$ & $0.0614(9)$ & $0.0081(7)$ & $0.0188(7)$ & $0.0002(8)$ \\
C10 & $0.0638(10)$ & $0.0927(14)$ & $0.0693(11)$ & $0.0210(10)$ & $0.0173(9)$ & $-0.0073(10)$ \\
C11 & $0.0848(15)$ & $0.0903(16)$ & $0.1062(18)$ & $0.0155(12)$ & $0.0196(13)$ & $-0.0320(15)$ \\
C12 & $0.0933(16)$ & $0.0695(14)$ & $0.139(2)$ & $0.0118(12)$ & $0.0321(16)$ & $-0.0062(15)$ \\
C13 & $0.0887(15)$ & $0.0769(13)$ & $0.1043(17)$ & $0.0142(11)$ & $0.0320(13)$ & $0.0206(13)$ \\
C14 & $0.0649(10)$ & $0.0727(11)$ & $0.0673(10)$ & $0.0060(8)$ & $0.0213(8)$ & $0.0072(9)$ \\
C15 & $0.0585(9)$ & $0.0524(8)$ & $0.0588(9)$ & $0.0006(7)$ & $0.0219(7)$ & $-0.0042(7)$ \\
C16 & $0.0537(8)$ & $0.0460(7)$ & $0.0532(8)$ & $0.0023(6)$ & $0.0223(6)$ & $0.0026(6)$ \\
C17 & $0.0581(8)$ & $0.0425(7)$ & $0.0503(7)$ & $0.0016(6)$ & $0.0236(6)$ & $0.0085(6)$ \\
C18 & $0.0748(11)$ & $0.0516(8)$ & $0.0613(9)$ & $0.0005(7)$ & $0.0357(8)$ & $0.0007(7)$ \\
C19 & $0.1042(15)$ & $0.0615(10)$ & $0.0650(10)$ & $-0.0013(10)$ & $0.0414(11)$ & $-0.0083(8)$ \\
C20 & $0.1085(16)$ & $0.0655(11)$ & $0.0537(9)$ & $-0.0138(10)$ & $0.0180(10)$ & $-0.0076(8)$ \\
C21 & $0.0688(10)$ & $0.0644(10)$ & $0.0560(9)$ & $-0.0103(8)$ & $0.0117(8)$ & $0.0086(8)$ \\
C22 & $0.0611(9)$ & $0.0486(8)$ & $0.0486(8)$ & $0.0003(6)$ & $0.0187(7)$ & $0.0111(6)$ \\
& & & & & &
\end{tabular}




\begin{tabular}{lllllll}
$\mathrm{C} 23$ & $0.0600(9)$ & $0.0555(8)$ & $0.0557(8)$ & $0.0047(7)$ & $0.0236(7)$ & $-0.0024(7)$ \\
$\mathrm{C} 24$ & $0.0540(10)$ & $0.0998(16)$ & $0.0919(14)$ & $0.0166(10)$ & $0.0231(10)$ & $0.0061(13)$ \\
$\mathrm{N} 1$ & $0.0530(7)$ & $0.0666(9)$ & $0.0714(9)$ & $-0.0037(6)$ & $0.0165(6)$ & $-0.0065(7)$ \\
$\mathrm{N} 2$ & $0.0498(7)$ & $0.0627(8)$ & $0.0663(8)$ & $-0.0020(6)$ & $0.0191(6)$ & $-0.0072(7)$ \\
$\mathrm{N} 3$ & $0.0515(7)$ & $0.0610(8)$ & $0.0575(7)$ & $0.0046(6)$ & $0.0206(6)$ & $0.0057(6)$ \\
$\mathrm{O} 1$ & $0.0949(10)$ & $0.0924(10)$ & $0.0669(8)$ & $-0.0030(8)$ & $0.0239(7)$ & $0.0199(7)$ \\
\hline
\end{tabular}

Geometric parameters $\left(\AA,{ }^{\circ}\right)$

\begin{tabular}{|c|c|c|c|}
\hline $\mathrm{C} 1-\mathrm{N} 1$ & $1.286(2)$ & $\mathrm{C} 13-\mathrm{H} 13$ & 0.9300 \\
\hline $\mathrm{C} 1-\mathrm{C} 2$ & $1.474(2)$ & $\mathrm{C} 14-\mathrm{H} 14$ & 0.9300 \\
\hline $\mathrm{C} 1-\mathrm{C} 8$ & $1.515(2)$ & $\mathrm{C} 15-\mathrm{N} 2$ & $1.286(2)$ \\
\hline $\mathrm{C} 2-\mathrm{C} 7$ & $1.383(3)$ & $\mathrm{C} 15-\mathrm{C} 16$ & $1.427(2)$ \\
\hline $\mathrm{C} 2-\mathrm{C} 3$ & $1.385(3)$ & C15-H15 & 0.9300 \\
\hline $\mathrm{C} 3-\mathrm{C} 4$ & $1.386(3)$ & $\mathrm{C} 16-\mathrm{C} 23$ & $1.376(2)$ \\
\hline $\mathrm{C} 3-\mathrm{H} 3$ & 0.9300 & $\mathrm{C} 16-\mathrm{C} 17$ & $1.434(2)$ \\
\hline $\mathrm{C} 4-\mathrm{C} 5$ & $1.375(4)$ & $\mathrm{C} 17-\mathrm{C} 18$ & $1.399(2)$ \\
\hline $\mathrm{C} 4-\mathrm{H} 4$ & 0.9300 & $\mathrm{C} 17-\mathrm{C} 22$ & $1.404(2)$ \\
\hline $\mathrm{C} 5-\mathrm{C} 6$ & $1.355(4)$ & $\mathrm{C} 18-\mathrm{C} 19$ & $1.371(3)$ \\
\hline $\mathrm{C} 5-\mathrm{H} 5$ & 0.9300 & $\mathrm{C} 18-\mathrm{H} 18$ & 0.9300 \\
\hline $\mathrm{C} 6-\mathrm{C} 7$ & $1.384(3)$ & $\mathrm{C} 19-\mathrm{C} 20$ & $1.392(3)$ \\
\hline C6- $-\mathrm{H} 6$ & 0.9300 & C19-H19 & 0.9300 \\
\hline $\mathrm{C} 7-\mathrm{H} 7$ & 0.9300 & $\mathrm{C} 20-\mathrm{C} 21$ & 1.375 \\
\hline $\mathrm{C} 8-\mathrm{O} 1$ & $1.214(2)$ & $\mathrm{C} 20-\mathrm{H} 20$ & 0.9300 \\
\hline $\mathrm{C} 8-\mathrm{C} 9$ & $1.483(3)$ & $\mathrm{C} 21-\mathrm{C} 22$ & $1.389(2)$ \\
\hline $\mathrm{C} 9-\mathrm{C} 14$ & $1.382(2)$ & $\mathrm{C} 21-\mathrm{H} 21$ & 0.9300 \\
\hline $\mathrm{C} 9-\mathrm{C} 10$ & $1.385(3)$ & $\mathrm{C} 22-\mathrm{N} 3$ & $1.389(2)$ \\
\hline $\mathrm{C} 10-\mathrm{C} 11$ & $1.388(3)$ & $\mathrm{C} 23-\mathrm{N} 3$ & $1.353(2)$ \\
\hline $\mathrm{C} 10-\mathrm{H} 10$ & 0.9300 & $\mathrm{C} 23-\mathrm{H} 23$ & 0.9300 \\
\hline $\mathrm{C} 11-\mathrm{C} 12$ & $1.364(4)$ & $\mathrm{C} 24-\mathrm{N} 3$ & $1.452(2)$ \\
\hline $\mathrm{C} 11-\mathrm{H} 11$ & 0.9300 & $\mathrm{C} 24-\mathrm{H} 24 \mathrm{~A}$ & 0.9600 \\
\hline $\mathrm{C} 12-\mathrm{C} 13$ & $1.374(4)$ & $\mathrm{C} 24-\mathrm{H} 24 \mathrm{~B}$ & 0.9600 \\
\hline $\mathrm{C} 12-\mathrm{H} 12$ & 0.9300 & $\mathrm{C} 24-\mathrm{H} 24 \mathrm{C}$ & 0.9600 \\
\hline $\mathrm{C} 13-\mathrm{C} 14$ & $1.379(3)$ & $\mathrm{N} 1-\mathrm{N} 2$ & $1.4077(19)$ \\
\hline $\mathrm{N} 1-\mathrm{C} 1-\mathrm{C} 2$ & $120.14(17)$ & $\mathrm{C} 13-\mathrm{C} 14-\mathrm{H} 14$ & 119.7 \\
\hline $\mathrm{N} 1-\mathrm{C} 1-\mathrm{C} 8$ & $120.11(15)$ & C9-C14-H14 & 119.7 \\
\hline $\mathrm{C} 2-\mathrm{C} 1-\mathrm{C} 8$ & $119.72(15)$ & $\mathrm{N} 2-\mathrm{C} 15-\mathrm{C} 16$ & $122.45(15)$ \\
\hline $\mathrm{C} 7-\mathrm{C} 2-\mathrm{C} 3$ & $118.56(19)$ & $\mathrm{N} 2-\mathrm{C} 15-\mathrm{H} 15$ & 118.8 \\
\hline $\mathrm{C} 7-\mathrm{C} 2-\mathrm{C} 1$ & $120.41(19)$ & $\mathrm{C} 16-\mathrm{C} 15-\mathrm{H} 15$ & 118.8 \\
\hline $\mathrm{C} 3-\mathrm{C} 2-\mathrm{C} 1$ & $121.03(18)$ & $\mathrm{C} 23-\mathrm{C} 16-\mathrm{C} 15$ & $123.72(15)$ \\
\hline $\mathrm{C} 2-\mathrm{C} 3-\mathrm{C} 4$ & $120.3(2)$ & $\mathrm{C} 23-\mathrm{C} 16-\mathrm{C} 17$ & $106.40(14)$ \\
\hline $\mathrm{C} 2-\mathrm{C} 3-\mathrm{H} 3$ & 119.9 & $\mathrm{C} 15-\mathrm{C} 16-\mathrm{C} 17$ & $129.73(14)$ \\
\hline $\mathrm{C} 4-\mathrm{C} 3-\mathrm{H} 3$ & 119.9 & $\mathrm{C} 18-\mathrm{C} 17-\mathrm{C} 22$ & $118.90(15)$ \\
\hline $\mathrm{C} 5-\mathrm{C} 4-\mathrm{C} 3$ & $120.2(3)$ & $\mathrm{C} 18-\mathrm{C} 17-\mathrm{C} 16$ & $134.43(15)$ \\
\hline $\mathrm{C} 5-\mathrm{C} 4-\mathrm{H} 4$ & 119.9 & $\mathrm{C} 22-\mathrm{C} 17-\mathrm{C} 16$ & $106.66(13)$ \\
\hline $\mathrm{C} 3-\mathrm{C} 4-\mathrm{H} 4$ & 119.9 & $\mathrm{C} 19-\mathrm{C} 18-\mathrm{C} 17$ & $118.49(17)$ \\
\hline $\mathrm{C} 6-\mathrm{C} 5-\mathrm{C} 4$ & $119.8(2)$ & $\mathrm{C} 19-\mathrm{C} 18-\mathrm{H} 18$ & 120.8 \\
\hline
\end{tabular}




$\begin{array}{llll}\mathrm{C} 6-\mathrm{C} 5-\mathrm{H} 5 & 120.1 & \mathrm{C} 17-\mathrm{C} 18-\mathrm{H} 18 & 120.8 \\ \mathrm{C} 4-\mathrm{C} 5-\mathrm{H} 5 & 120.1 & \mathrm{C} 18-\mathrm{C} 19-\mathrm{C} 20 & 121.50(17) \\ \mathrm{C} 5-\mathrm{C} 6-\mathrm{C} 7 & 120.7(3) & \mathrm{C} 18-\mathrm{C} 19-\mathrm{H} 19 & 119.2 \\ \mathrm{C} 5-\mathrm{C} 6-\mathrm{H} 6 & 119.6 & \mathrm{C} 20-\mathrm{C} 19-\mathrm{H} 19 & 119.2 \\ \mathrm{C} 7-\mathrm{C} 6-\mathrm{H} 6 & 119.6 & \mathrm{C} 21-\mathrm{C} 20-\mathrm{C} 19 & 121.71(18) \\ \mathrm{C} 2-\mathrm{C} 7-\mathrm{C} 6 & 120.4(3) & \mathrm{C} 21-\mathrm{C} 20-\mathrm{H} 20 & 119.1 \\ \mathrm{C} 2-\mathrm{C} 7-\mathrm{H} 7 & 119.8 & \mathrm{C} 19-\mathrm{C} 20-\mathrm{H} 20 & 119.1 \\ \mathrm{C} 6-\mathrm{C} 7-\mathrm{H} 7 & 119.8 & \mathrm{C} 20-\mathrm{C} 21-\mathrm{C} 22 & 121.6 \\ \mathrm{O} 1-\mathrm{C} 8-\mathrm{C} 9 & 122.88(17) & \mathrm{C} 20-\mathrm{C} 21-\mathrm{H} 21 & 121.6 \\ \mathrm{O} 1-\mathrm{C} 8-\mathrm{C} 1 & 118.77(18) & \mathrm{C} 22-\mathrm{C} 21-\mathrm{H} 21 & 129.45(16) \\ \mathrm{C} 9-\mathrm{C} 8-\mathrm{C} 1 & 118.35(14) & \mathrm{C} 21-\mathrm{C} 22-\mathrm{N} 3 & 122.67(15) \\ \mathrm{C} 14-\mathrm{C} 9-\mathrm{C} 10 & 119.15(19) & \mathrm{C} 21-\mathrm{C} 22-\mathrm{C} 17 & 107.87(13) \\ \mathrm{C} 14-\mathrm{C} 9-\mathrm{C} 8 & 121.27(16) & \mathrm{N} 3-\mathrm{C} 22-\mathrm{C} 17 & 110.52(14) \\ \mathrm{C} 10-\mathrm{C} 9-\mathrm{C} 8 & 119.58(17) & \mathrm{N} 3-\mathrm{C} 23-\mathrm{C} 16 & 124.7 \\ \mathrm{C} 9-\mathrm{C} 10-\mathrm{C} 11 & 119.6(2) & \mathrm{N} 3-\mathrm{C} 23-\mathrm{H} 23 & 109.5 \\ \mathrm{C} 9-\mathrm{C} 10-\mathrm{H} 10 & 120.2 & \mathrm{C} 16-\mathrm{C} 23-\mathrm{H} 23 & 109.5 \\ \mathrm{C} 11-\mathrm{C} 10-\mathrm{H} 10 & 120.2 & \mathrm{~N} 3-\mathrm{C} 24-\mathrm{H} 24 \mathrm{~A} & 109.5 \\ \mathrm{C} 12-\mathrm{C} 11-\mathrm{C} 10 & 120.7(2) & \mathrm{N} 3-\mathrm{C} 24-\mathrm{H} 24 \mathrm{~B} & 109.5 \\ \mathrm{C} 12-\mathrm{C} 11-\mathrm{H} 11 & 119.7 & \mathrm{H} 24 \mathrm{C}-\mathrm{C} 24-\mathrm{H} 24 \mathrm{~B} & 109.5 \\ \mathrm{C} 10-\mathrm{C} 11-\mathrm{H} 11 & 119.7 & \mathrm{~N} 3-\mathrm{C} 24-\mathrm{H} 24 \mathrm{C} & 109.5 \\ \mathrm{C} 11-\mathrm{C} 12-\mathrm{C} 13 & 120.1(2) & \mathrm{H} 24 \mathrm{C}-\mathrm{C} 24-\mathrm{H} 24 \mathrm{C} & 111.71(15) \\ \mathrm{C} 11-\mathrm{C} 12-\mathrm{H} 124 \mathrm{C} & 111.49(14) \\ \mathrm{C} 13-\mathrm{C} 12-\mathrm{H} 12 & 120.0 & \mathrm{C} 1-\mathrm{N} 1-\mathrm{N} 2 & 108.54(13) \\ \mathrm{C} 12-\mathrm{C} 13-\mathrm{C} 14 & 120.0 & \mathrm{C} 15-\mathrm{N} 2-\mathrm{N} 1 & 125.92(16) \\ \mathrm{C} 12-\mathrm{C} 13-\mathrm{H} 13 & 119.8(2) & \mathrm{C} 23-\mathrm{N} 3-\mathrm{C} 22 & 125.50(16) \\ \mathrm{C} 14-\mathrm{C} 13-\mathrm{H} 13 & 120.1 & \mathrm{C} 22-\mathrm{N} 3-\mathrm{N} 3-\mathrm{C} 24 & \\ \mathrm{C} 13-\mathrm{C} 14-\mathrm{C} 9 & 120.1 & & \end{array}$

(Z)-2-\{(E)-[(Naphthalen-1-yl)methylidene]hydrazinylidene\}-1,2-diphenylethanone (8-BDHFN)

\section{Crystal data}

\section{$\mathrm{C}_{25} \mathrm{H}_{18} \mathrm{~N}_{2} \mathrm{O}$}

$M_{r}=362.41$

Monoclinic, $P 2_{1} / c$

$a=17.2081(13) \AA$

$b=9.4075(8) \AA$

$c=11.9703(9) \AA$

$\beta=94.814(7)^{\circ}$

$V=1931.0(3) \AA^{3}$

$Z=4$

\section{Data collection}

Bruker SMART CCD area detector diffractometer

Radiation source: fine-focus sealed tube Detector resolution: 10.12 pixels $\mathrm{mm}^{-1}$ phi and $\omega$ scans

Absorption correction: multi-scan

(SADABS; Bruker, 2000)

$T_{\min }=0.970, T_{\max }=0.989$
$F(000)=760$

$D_{\mathrm{x}}=1.247 \mathrm{Mg} \mathrm{m}^{-3}$

Mo $K \alpha$ radiation, $\lambda=0.71073 \AA$

Cell parameters from 380 reflections

$\theta=2.5-26.0^{\circ}$

$\mu=0.08 \mathrm{~mm}^{-1}$

$T=293 \mathrm{~K}$

Block, yellow

$0.40 \times 0.40 \times 0.16 \mathrm{~mm}$

10556 measured reflections

3396 independent reflections

1411 reflections with $I>2 \sigma(I)$

$R_{\text {int }}=0.078$

$\theta_{\text {max }}=25.0^{\circ}, \theta_{\min }=3.0^{\circ}$

$h=-20 \rightarrow 20$

$k=-11 \rightarrow 10$

$l=-14 \rightarrow 14$ 


\section{Refinement}

Refinement on $F^{2}$

Least-squares matrix: full

$R\left[F^{2}>2 \sigma\left(F^{2}\right)\right]=0.052$

$w R\left(F^{2}\right)=0.083$

$S=0.87$

3396 reflections

272 parameters

0 restraints

Hydrogen site location: inferred from neighbouring sites
Only $\mathrm{H}$-atom displacement parameters refined

$w=1 /\left[\sigma^{2}\left(F_{\mathrm{o}}^{2}\right)+(0.0024 P)^{2}\right]$ where $P=\left(F_{\mathrm{o}}{ }^{2}+2 F_{\mathrm{c}}{ }^{2}\right) / 3$

$(\Delta / \sigma)_{\max }<0.001$

$\Delta \rho_{\max }=0.14 \mathrm{e} \AA^{-3}$

$\Delta \rho_{\min }=-0.14 \mathrm{e} \AA^{-3}$

Extinction correction: SHELXL2016 (Sheldrick, 2015b), $\mathrm{Fc}^{*}=\mathrm{kFc}\left[1+0.001 \mathrm{xFc}^{2} \lambda^{3} / \sin (2 \theta)\right]^{-1 / 4}$

Extinction coefficient: 0.00135 (15)

Special details

Geometry. All esds (except the esd in the dihedral angle between two 1.s. planes) are estimated using the full covariance matrix. The cell esds are taken into account individually in the estimation of esds in distances, angles and torsion angles; correlations between esds in cell parameters are only used when they are defined by crystal symmetry. An approximate (isotropic) treatment of cell esds is used for estimating esds involving 1.s. planes.

Fractional atomic coordinates and isotropic or equivalent isotropic displacement parameters $\left(\AA^{2}\right)$

\begin{tabular}{|c|c|c|c|c|}
\hline & $x$ & $y$ & $z$ & $U_{\text {iso }} * / U_{\text {eq }}$ \\
\hline $\mathrm{C} 1$ & $0.38170(16)$ & $0.3245(3)$ & $0.5324(2)$ & $0.0479(7)$ \\
\hline $\mathrm{C} 2$ & $0.45003(16)$ & 0.2405 & $0.5767(2)$ & $0.0492(8)$ \\
\hline $\mathrm{C} 3$ & $0.51422(17)$ & $0.2274(3)$ & 0.5158 & $0.0695(10)$ \\
\hline H3 & 0.515242 & 0.274493 & 0.447585 & $0.063(9)^{*}$ \\
\hline $\mathrm{C} 4$ & $0.57683(19)$ & $0.1451(4)$ & 0.5553 & $0.0787(11)$ \\
\hline $\mathrm{H} 4$ & 0.619504 & 0.135979 & 0.513009 & $0.096(12)^{*}$ \\
\hline $\mathrm{C} 5$ & $0.57676(19)$ & $0.0761(4)$ & $0.6569(3)$ & $0.0700(10)$ \\
\hline H5 & 0.619147 & 0.020890 & 0.683658 & $0.072(10)^{*}$ \\
\hline C6 & $0.51344(19)$ & 0.0901 (3) & 0.7175 & $0.0696(10)$ \\
\hline H6 & 0.512814 & 0.044390 & 0.786371 & $0.077(10)^{*}$ \\
\hline $\mathrm{C} 7$ & $0.45071(18)$ & $0.1709(3)$ & $0.6779(2)$ & $0.0628(9)$ \\
\hline $\mathrm{H} 7$ & 0.407940 & 0.178794 & 0.720078 & $0.051(8)^{*}$ \\
\hline $\mathrm{C} 8$ & $0.30593(16)$ & $0.3112(3)$ & $0.5892(2)$ & $0.0506(8)$ \\
\hline $\mathrm{C} 9$ & $0.24449(15)$ & 0.2118 & $0.5424(2)$ & $0.0471(7)$ \\
\hline C10 & $0.25215(19)$ & $0.1364(3)$ & $0.4446(2)$ & $0.0645(9)$ \\
\hline H10 & 0.296674 & 0.147167 & 0.406439 & $0.068(10)^{*}$ \\
\hline $\mathrm{C} 11$ & $0.1942(2)$ & $0.0460(4)$ & $0.4042(3)$ & $0.0811(11)$ \\
\hline H11 & 0.199667 & -0.004809 & 0.338738 & $0.075(11)^{*}$ \\
\hline $\mathrm{C} 12$ & $0.1284(2)$ & $0.0298(4)$ & $0.4592(4)$ & $0.0904(12)$ \\
\hline H12 & 0.089288 & -0.032034 & 0.431149 & $0.105(14)^{*}$ \\
\hline $\mathrm{C} 13$ & $0.1199(2)$ & $0.1044(4)$ & $0.5554(3)$ & $0.0878(12)$ \\
\hline H13 & 0.074829 & 0.093934 & 0.592373 & $0.111(13)^{*}$ \\
\hline $\mathrm{C} 14$ & $0.17771(18)$ & 0.1948 (4) & 0.5978 & $0.0675(10)$ \\
\hline H14 & 0.171980 & 0.244559 & 0.663753 & $0.075(11)^{*}$ \\
\hline $\mathrm{C} 15$ & $0.31775(17)$ & 0.5533 & $0.3302(2)$ & $0.0556(8)$ \\
\hline H15 & 0.366978 & 0.567807 & 0.305639 & $0.066(9)^{*}$ \\
\hline C16 & $0.25293(16)$ & $0.6289(3)$ & $0.2709(2)$ & $0.0491(8)$ \\
\hline $\mathrm{C} 17$ & $0.27243(19)$ & 0.7208 & $0.1884(2)$ & $0.0634(9)$ \\
\hline
\end{tabular}




$\begin{array}{lllll}\text { H17 } & 0.324544 & 0.731061 & 0.174771 & 0.042(7)^{*} \\ \text { C18 } & 0.2158(2) & 0.7989(3) & 0.1247(3) & 0.0724(10) \\ \text { H18 } & 0.230588 & 0.860029 & 0.069249 & 0.075(10)^{*} \\ \text { C19 } & 0.1399(2) & 0.7866(4) & 0.1429(3) & 0.0739(10) \\ \text { H19 } & 0.102806 & 0.839726 & 0.100082 & 0.099(12)^{*} \\ \text { C20 } & 0.11607(19) & 0.6942(3) & 0.2262(2) & 0.0578(8) \\ \text { C21 } & 0.17273(17) & 0.6118(3) & 0.2911(2) & 0.0489(8) \\ \text { C22 } & 0.14497(17) & 0.5146(3) & 0.3686(2) & 0.0534(8) \\ \text { H22 } & 0.180386 & 0.457731 & 0.411164 & 0.053(9)^{*} \\ \text { C23 } & 0.06746(18) & 0.5025(3) & 0.3824(2) & 0.0632(9) \\ \text { H23 } & 0.050872 & 0.437604 & 0.433924 & 0.039(8)^{*} \\ \text { C24 } & 0.0127(2) & 0.5861(4) & 0.3203(3) & 0.0771(10) \\ \text { H24 } & -0.039946 & 0.578124 & 0.331423 & 0.100(12)^{*} \\ \text { C25 } & 0.0365(2) & 0.6792(4) & 0.2435(3) & 0.0790(11) \\ \text { H25 } & -0.000333 & 0.733990 & 0.201654 & 0.074(10)^{*} \\ \text { N1 } & 0.38670(13) & 0.4055(3) & 0.44718(19) & 0.0589(7) \\ \text { N2 } & 0.31309(13) & 0.4685(3) & 0.41351(19) & 0.0569(7) \\ \text { O1 } & 0.29977(11) & 0.3808(2) & 0.67417(16) & 0.0753(7)\end{array}$

Atomic displacement parameters $\left(\AA^{2}\right)$

\begin{tabular}{|c|c|c|c|c|c|c|}
\hline & $U^{11}$ & $U^{22}$ & $U^{33}$ & $U^{12}$ & $U^{13}$ & $U^{23}$ \\
\hline $\mathrm{C} 1$ & $0.0473(18)$ & $0.049(2)$ & $0.0467(17)$ & $0.0024(16)$ & $0.0003(14)$ & $-0.0007(15)$ \\
\hline $\mathrm{C} 2$ & $0.0482(18)$ & $0.055(2)$ & $0.0429(18)$ & $0.0022(16)$ & $-0.0030(15)$ & $0.0009(15)$ \\
\hline $\mathrm{C} 3$ & $0.061(2)$ & $0.090(3)$ & $0.059(2)$ & $0.013(2)$ & $0.0103(18)$ & $0.021(2)$ \\
\hline $\mathrm{C} 4$ & $0.051(2)$ & $0.104(3)$ & $0.081(3)$ & $0.019(2)$ & $0.012(2)$ & $0.013(2)$ \\
\hline $\mathrm{C} 5$ & $0.056(2)$ & $0.081(3)$ & $0.071(2)$ & $0.024(2)$ & $-0.0086(18)$ & $-0.002(2)$ \\
\hline C6 & $0.073(2)$ & $0.081(3)$ & $0.053(2)$ & $0.022(2)$ & $-0.0043(18)$ & $0.010(2)$ \\
\hline $\mathrm{C} 7$ & $0.062(2)$ & $0.074(3)$ & $0.0531(19)$ & $0.0133(19)$ & $0.0109(18)$ & $0.0073(18)$ \\
\hline $\mathrm{C} 8$ & $0.0479(19)$ & $0.056(2)$ & $0.0477(17)$ & $0.0112(17)$ & $0.0042(15)$ & $0.0088(16)$ \\
\hline C9 & $0.0436(17)$ & $0.046(2)$ & $0.0520(18)$ & $0.0033(16)$ & $0.0070(14)$ & $0.0075(15)$ \\
\hline $\mathrm{C} 10$ & $0.063(2)$ & $0.071(3)$ & $0.060(2)$ & -0.009 (2) & $0.0118(19)$ & $-0.0078(18)$ \\
\hline C11 & $0.084(3)$ & $0.078(3)$ & $0.079(3)$ & $-0.015(2)$ & $-0.003(2)$ & $-0.016(2)$ \\
\hline $\mathrm{C} 12$ & $0.074(3)$ & $0.093(3)$ & $0.101(3)$ & -0.028 & $-0.010(3)$ & $0.020(3)$ \\
\hline $\mathrm{C} 13$ & $0.060(3)$ & $0.113(4)$ & $0.092(3)$ & $-0.011(2)$ & $0.013(2)$ & $0.020(3)$ \\
\hline $\mathrm{C} 14$ & $0.059(2)$ & $0.086(3)$ & $0.059(2)$ & $0.006(2)$ & $0.0130(18)$ & $0.007(2)$ \\
\hline $\mathrm{C} 15$ & $0.046(2)$ & $0.061(2)$ & $0.060(2)$ & $0.0003(17)$ & $0.0028(16)$ & $0.0022(17)$ \\
\hline $\mathrm{C} 16$ & $0.054(2)$ & $0.048(2)$ & $0.0447(17)$ & $0.0007(17)$ & $0.0011(15)$ & $-0.0002(15)$ \\
\hline $\mathrm{C} 17$ & $0.060(2)$ & $0.069(3)$ & $0.061(2)$ & -0.0101 (19) & $0.0059(18)$ & $0.0118(18)$ \\
\hline $\mathrm{C} 18$ & $0.094(3)$ & $0.059(2)$ & $0.062(2)$ & $-0.002(2)$ & $-0.008(2)$ & $0.0230(19)$ \\
\hline C19 & $0.077(3)$ & $0.068(3)$ & $0.074(2)$ & $0.007(2)$ & $-0.009(2)$ & $0.012(2)$ \\
\hline $\mathrm{C} 20$ & $0.066(2)$ & 0.049 (2) & $0.057(2)$ & $0.0008(19)$ & $-0.0016(17)$ & $-0.0001(17)$ \\
\hline $\mathrm{C} 21$ & $0.059(2)$ & $0.045(2)$ & $0.0420(17)$ & $0.0005(17)$ & $-0.0022(15)$ & $0.0001(15)$ \\
\hline $\mathrm{C} 22$ & $0.054(2)$ & $0.057(2)$ & $0.0481(18)$ & $0.0011(18)$ & $-0.0054(16)$ & $0.0010(17)$ \\
\hline $\mathrm{C} 23$ & $0.062(2)$ & $0.064(2)$ & $0.064(2)$ & $-0.001(2)$ & $0.0039(18)$ & $0.0066(19)$ \\
\hline $\mathrm{C} 24$ & $0.055(2)$ & $0.082(3)$ & $0.094(3)$ & $0.006(2)$ & $0.003(2)$ & $0.006(2)$ \\
\hline $\mathrm{C} 25$ & $0.070(3)$ & $0.074(3)$ & 0.089 & $0.019(2)$ & $-0.011(2)$ & $0.020(2)$ \\
\hline N1 & $0.0497(16)$ & $0.0657(19)$ & $0.0605(16)$ & $0.0099(14)$ & $-0.0009(13)$ & $0.0128(14)$ \\
\hline
\end{tabular}




\begin{tabular}{lllllll}
$\mathrm{N} 2$ & $0.0538(17)$ & $0.0599(19)$ & $0.0564(16)$ & $0.0068(14)$ & $0.0019(13)$ & $0.0143(13)$ \\
$\mathrm{O} 1$ & $0.0744(16)$ & $0.0946(19)$ & $0.0576(13)$ & $0.0072(13)$ & $0.0088(11)$ & $-0.0200(13)$ \\
\hline
\end{tabular}

Geometric parameters $\left(\AA,{ }^{\circ}\right)$

\begin{tabular}{|c|c|c|c|}
\hline $\mathrm{C} 1-\mathrm{N} 1$ & $1.282(3)$ & $\mathrm{C} 13-\mathrm{H} 13$ & 0.9300 \\
\hline $\mathrm{C} 1-\mathrm{C} 2$ & $1.478(3)$ & $\mathrm{C} 14-\mathrm{H} 14$ & 0.9300 \\
\hline $\mathrm{C} 1-\mathrm{C} 8$ & $1.525(3)$ & $\mathrm{C} 15-\mathrm{N} 2$ & $1.284(3)$ \\
\hline $\mathrm{C} 2-\mathrm{C} 7$ & $1.376(3)$ & $\mathrm{C} 15-\mathrm{C} 16$ & $1.457(3)$ \\
\hline $\mathrm{C} 2-\mathrm{C} 3$ & $1.379(3)$ & $\mathrm{C} 15-\mathrm{H} 15$ & 0.9300 \\
\hline $\mathrm{C} 3-\mathrm{C} 4$ & $1.378(4)$ & $\mathrm{C} 16-\mathrm{C} 17$ & $1.374(3)$ \\
\hline $\mathrm{C} 3-\mathrm{H} 3$ & 0.9300 & $\mathrm{C} 16-\mathrm{C} 21$ & $1.430(3)$ \\
\hline $\mathrm{C} 4-\mathrm{C} 5$ & $1.379(4)$ & $\mathrm{C} 17-\mathrm{C} 18$ & $1.395(4)$ \\
\hline $\mathrm{C} 4-\mathrm{H} 4$ & 0.9300 & C17-H17 & 0.9300 \\
\hline $\mathrm{C} 5-\mathrm{C} 6$ & $1.366(4)$ & $\mathrm{C} 18-\mathrm{C} 19$ & $1.347(4)$ \\
\hline $\mathrm{C} 5-\mathrm{H} 5$ & 0.9300 & $\mathrm{C} 18-\mathrm{H} 18$ & 0.9300 \\
\hline $\mathrm{C} 6-\mathrm{C} 7$ & $1.372(3)$ & $\mathrm{C} 19-\mathrm{C} 20$ & 1.409 (4) \\
\hline C6- 6 6 & 0.9300 & C19-H19 & 0.9300 \\
\hline $\mathrm{C} 7-\mathrm{H} 7$ & 0.9300 & $\mathrm{C} 20-\mathrm{C} 25$ & $1.409(4)$ \\
\hline $\mathrm{C} 8-\mathrm{O} 1$ & $1.221(3)$ & $\mathrm{C} 20-\mathrm{C} 21$ & $1.424(3)$ \\
\hline $\mathrm{C} 8-\mathrm{C} 9$ & $1.486(4)$ & $\mathrm{C} 21-\mathrm{C} 22$ & $1.414(3)$ \\
\hline $\mathrm{C} 9-\mathrm{C} 10$ & $1.384(3)$ & $\mathrm{C} 22-\mathrm{C} 23$ & $1.362(3)$ \\
\hline $\mathrm{C} 9-\mathrm{C} 14$ & $1.384(3)$ & $\mathrm{C} 22-\mathrm{H} 22$ & 0.9300 \\
\hline $\mathrm{C} 10-\mathrm{C} 11$ & $1.367(4)$ & $\mathrm{C} 23-\mathrm{C} 24$ & $1.393(4)$ \\
\hline $\mathrm{C} 10-\mathrm{H} 10$ & 0.9300 & $\mathrm{C} 23-\mathrm{H} 23$ & 0.9300 \\
\hline $\mathrm{C} 11-\mathrm{C} 12$ & $1.365(4)$ & $\mathrm{C} 24-\mathrm{C} 25$ & $1.357(4)$ \\
\hline $\mathrm{C} 11-\mathrm{H} 11$ & 0.9300 & $\mathrm{C} 24-\mathrm{H} 24$ & 0.9300 \\
\hline $\mathrm{C} 12-\mathrm{C} 13$ & $1.368(4)$ & $\mathrm{C} 25-\mathrm{H} 25$ & 0.9300 \\
\hline $\mathrm{C} 12-\mathrm{H} 12$ & 0.9300 & $\mathrm{~N} 1-\mathrm{N} 2$ & $1.426(3)$ \\
\hline $\mathrm{C} 13-\mathrm{C} 14$ & $1.372(4)$ & & \\
\hline $\mathrm{N} 1-\mathrm{C} 1-\mathrm{C} 2$ & $119.9(3)$ & $\mathrm{C} 13-\mathrm{C} 14-\mathrm{C} 9$ & $120.0(3)$ \\
\hline $\mathrm{N} 1-\mathrm{C} 1-\mathrm{C} 8$ & $121.4(3)$ & $\mathrm{C} 13-\mathrm{C} 14-\mathrm{H} 14$ & 120.0 \\
\hline $\mathrm{C} 2-\mathrm{C} 1-\mathrm{C} 8$ & $118.7(2)$ & $\mathrm{C} 9-\mathrm{C} 14-\mathrm{H} 14$ & 120.0 \\
\hline $\mathrm{C} 7-\mathrm{C} 2-\mathrm{C} 3$ & $118.4(3)$ & $\mathrm{N} 2-\mathrm{C} 15-\mathrm{C} 16$ & $125.9(3)$ \\
\hline $\mathrm{C} 7-\mathrm{C} 2-\mathrm{C} 1$ & $121.2(3)$ & $\mathrm{N} 2-\mathrm{C} 15-\mathrm{H} 15$ & 117.0 \\
\hline $\mathrm{C} 3-\mathrm{C} 2-\mathrm{C} 1$ & $120.4(3)$ & $\mathrm{C} 16-\mathrm{C} 15-\mathrm{H} 15$ & 117.0 \\
\hline $\mathrm{C} 4-\mathrm{C} 3-\mathrm{C} 2$ & $120.4(3)$ & $\mathrm{C} 17-\mathrm{C} 16-\mathrm{C} 21$ & $119.3(3)$ \\
\hline $\mathrm{C} 4-\mathrm{C} 3-\mathrm{H} 3$ & 119.8 & $\mathrm{C} 17-\mathrm{C} 16-\mathrm{C} 15$ & $115.7(3)$ \\
\hline $\mathrm{C} 2-\mathrm{C} 3-\mathrm{H} 3$ & 119.8 & $\mathrm{C} 21-\mathrm{C} 16-\mathrm{C} 15$ & $124.9(3)$ \\
\hline $\mathrm{C} 3-\mathrm{C} 4-\mathrm{C} 5$ & $120.6(3)$ & $\mathrm{C} 16-\mathrm{C} 17-\mathrm{C} 18$ & $121.5(3)$ \\
\hline $\mathrm{C} 3-\mathrm{C} 4-\mathrm{H} 4$ & 119.7 & $\mathrm{C} 16-\mathrm{C} 17-\mathrm{H} 17$ & 119.3 \\
\hline $\mathrm{C} 5-\mathrm{C} 4-\mathrm{H} 4$ & 119.7 & $\mathrm{C} 18-\mathrm{C} 17-\mathrm{H} 17$ & 119.3 \\
\hline $\mathrm{C} 6-\mathrm{C} 5-\mathrm{C} 4$ & $118.9(3)$ & $\mathrm{C} 19-\mathrm{C} 18-\mathrm{C} 17$ & $120.6(3)$ \\
\hline $\mathrm{C} 6-\mathrm{C} 5-\mathrm{H} 5$ & 120.5 & $\mathrm{C} 19-\mathrm{C} 18-\mathrm{H} 18$ & 119.7 \\
\hline $\mathrm{C} 4-\mathrm{C} 5-\mathrm{H} 5$ & 120.5 & $\mathrm{C} 17-\mathrm{C} 18-\mathrm{H} 18$ & 119.7 \\
\hline $\mathrm{C} 5-\mathrm{C} 6-\mathrm{C} 7$ & $120.6(3)$ & $\mathrm{C} 18-\mathrm{C} 19-\mathrm{C} 20$ & $120.7(3)$ \\
\hline $\mathrm{C} 5-\mathrm{C} 6-\mathrm{H} 6$ & 119.7 & $\mathrm{C} 18-\mathrm{C} 19-\mathrm{H} 19$ & 119.6 \\
\hline
\end{tabular}




$\begin{array}{llll}\mathrm{C} 7-\mathrm{C} 6-\mathrm{H} 6 & 119.7 & \mathrm{C} 20-\mathrm{C} 19-\mathrm{H} 19 & 119.6 \\ \mathrm{C} 6-\mathrm{C} 7-\mathrm{C} 2 & 121.1(3) & \mathrm{C} 25-\mathrm{C} 20-\mathrm{C} 19 & 120.6(3) \\ \mathrm{C} 6-\mathrm{C} 7-\mathrm{H} 7 & 119.4 & \mathrm{C} 25-\mathrm{C} 20-\mathrm{C} 21 & 119.6(3) \\ \mathrm{C} 2-\mathrm{C} 7-\mathrm{H} 7 & 119.4 & \mathrm{C} 19-\mathrm{C} 20-\mathrm{C} 21 & 119.7(3) \\ \mathrm{O} 1-\mathrm{C} 8-\mathrm{C} 9 & 122.9(3) & \mathrm{C} 22-\mathrm{C} 21-\mathrm{C} 20 & 117.2(3) \\ \mathrm{O} 1-\mathrm{C} 8-\mathrm{C} 1 & 117.6(3) & \mathrm{C} 22-\mathrm{C} 21-\mathrm{C} 16 & 124.6(3) \\ \mathrm{C} 9-\mathrm{C} 8-\mathrm{C} 1 & 119.4(3) & \mathrm{C} 20-\mathrm{C} 21-\mathrm{C} 16 & 118.2(3) \\ \mathrm{C} 10-\mathrm{C} 9-\mathrm{C} 14 & 119.2(3) & \mathrm{C} 23-\mathrm{C} 22-\mathrm{C} 21 & 119.3 \\ \mathrm{C} 10-\mathrm{C} 9-\mathrm{C} 8 & 121.8(3) & \mathrm{C} 23-\mathrm{C} 22-\mathrm{H} 22 & 119.3 \\ \mathrm{C} 14-\mathrm{C} 9-\mathrm{C} 8 & 119.0(3) & \mathrm{C} 21-\mathrm{C} 22-\mathrm{H} 22 & 120.9(3) \\ \mathrm{C} 11-\mathrm{C} 10-\mathrm{C} 9 & 119.9(3) & \mathrm{C} 22-\mathrm{C} 23-\mathrm{C} 24 & 119.5 \\ \mathrm{C} 11-\mathrm{C} 10-\mathrm{H} 10 & 120.0 & \mathrm{C} 22-\mathrm{C} 23-\mathrm{H} 23 & 119.5 \\ \mathrm{C} 9-\mathrm{C} 10-\mathrm{H} 10 & 120.0 & \mathrm{C} 24-\mathrm{C} 23-\mathrm{H} 23 & 119.8(3) \\ \mathrm{C} 12-\mathrm{C} 11-\mathrm{C} 10 & 120.6(4) & \mathrm{C} 25-\mathrm{C} 24-\mathrm{C} 23 & 120.1 \\ \mathrm{C} 12-\mathrm{C} 11-\mathrm{H} 11 & 119.7 & \mathrm{C} 25-\mathrm{C} 24-\mathrm{H} 24 & 121.1(3) \\ \mathrm{C} 10-\mathrm{C} 11-\mathrm{H} 11 & 119.7 & \mathrm{C} 23-\mathrm{C} 24-\mathrm{H} 24 & 119.5 \\ \mathrm{C} 11-\mathrm{C} 12-\mathrm{C} 13 & 120.0(4) & \mathrm{C} 24-\mathrm{C} 25-\mathrm{C} 20 & 119.5 \\ \mathrm{C} 11-\mathrm{C} 12-\mathrm{H} 12 & 120.0 & \mathrm{C} 24-\mathrm{C} 25-\mathrm{H} 25 & 110.8(2) \\ \mathrm{C} 13-\mathrm{C} 12-\mathrm{H} 12 & 120.0 & \mathrm{C} 20-\mathrm{C} 25-\mathrm{H} 25 & 111.5(2) \\ \mathrm{C} 12-\mathrm{C} 13-\mathrm{C} 14 & 120.3(4) & \mathrm{C} 1-\mathrm{N} 1-\mathrm{N} 2 & \\ \mathrm{C} 12-\mathrm{C} 13-\mathrm{H} 13 & 119.8 & \mathrm{C} 15-\mathrm{N} 2-\mathrm{N} 1 & \\ \mathrm{C} 14-\mathrm{C} 13-\mathrm{H} 13 & 119.8 & & \end{array}$

Hydrogen-bond geometry $\left(A,{ }^{\circ}\right)$

\begin{tabular}{lllll}
\hline$D-\mathrm{H} \cdots A$ & $D-\mathrm{H}$ & $\mathrm{H} \cdots A$ & $D \cdots A$ & $D-\mathrm{H} \cdots A$ \\
\hline $\mathrm{C} 5-\mathrm{H} 5 \cdots \mathrm{O} 1^{\mathrm{i}}$ & 0.93 & 2.49 & $3.355(4)$ & 156 \\
$\mathrm{C} 3-\mathrm{H} 3 \cdots \mathrm{N} 1$ & 0.93 & 2.53 & $2.827(4)$ & 99 \\
$\mathrm{C} 14-\mathrm{H} 14 \cdots \mathrm{O} 1$ & 0.93 & 2.54 & $2.826(4)$ & 98 \\
$\mathrm{C} 22-\mathrm{H} 22 \cdots \mathrm{N} 2$ & 0.93 & 2.28 & $2.930(4)$ & 126 \\
\hline
\end{tabular}

Symmetry code: (i) $-x+1, y-1 / 2,-z+3 / 2$. 